\title{
PATRICIA MACCHIAVERNI
}

\section{ALÉRGENOS AMBIENTAIS SÃO TRANSFERIDOS AO BEBÊ VIA PLACENTA E COLOSTRO NA PRESENÇA DE ANTICORPOS ESPECÍFICOS}

Tese apresentada ao Programa de Pós-Graduação em Imunologia do Instituto de Ciências Biomédicas da Universidade de São Paulo, para obtenção do Título de Doutor em Ciências. 


\section{PATRICIA MACCHIAVERNI}

\section{ALÉRGENOS AMBIENTAIS SÃO TRANSFERIDOS AO BEBÊ VIA PLACENTA E COLOSTRO NA PRESENÇA DE ANTICORPOS ESPECÍFICOS}

Tese apresentada ao Programa de Pós-Graduação em Imunologia do Instituto de Ciências Biomédicas da Universidade de São Paulo, para obtenção do Título de Doutor em Ciências.

Área de concentração: Imunologia

Orientador: Prof. Dr. Antônio Condino Neto

Versão original 
DADOS DE CATALOGAÇÃO NA PUBLICAÇÃO (CIP)

Serviço de Biblioteca e Informação Biomédica do

Instituto de Ciências Biomédicas da Universidade de São Paulo

(C) reprodução total

Macchiaverni, Patrícia.

Alérgenos ambientais são transferidos ao bebê via placenta e colostro na presença de anticorpos específicos / Patrícia

Macchiaverni. -- São Paulo, 2012.

Orientador: Prof. Dr. Antonio Condino Neto.

Tese (Doutorado) - Universidade de São Paulo. Instituto de Ciências Biomédicas. Departamento de Imunologia. Área de concentração: Imunologia. Linha de pesquisa: Imunologia em humanos.

Versão do título para o inglês: Airborne allergens can be transferred to the newborn through placenta and colostrum in the presence of maternal specific antibodies.

1. Alergia 2. Passagem transplacentária 3. Amamentação 4. Cordão umbilical 5. Alérgenos ambientais I. Condino Neto, Prof. Dr. Antonio II. Universidade de São Paulo. Instituto de Ciências Biomédicas. Programa de Pós-Graduação em Imunologia III. Título. 
Candidato(a): $\quad$ Patrícia Macchiaverni.

Título da Tese:

Alérgenos ambientais são transferidos ao bebê via placenta e colostro na presença de anticorpos específicos.

Orientador(a):

Prof. Dr. Antonio Condino Neto.

A Comissão Julgadora dos trabalhos de Defesa da Tese de Doutorado, em sessão pública realizada a .................., considerou
( ) Aprovado(a)
( ) Reprovado(a)

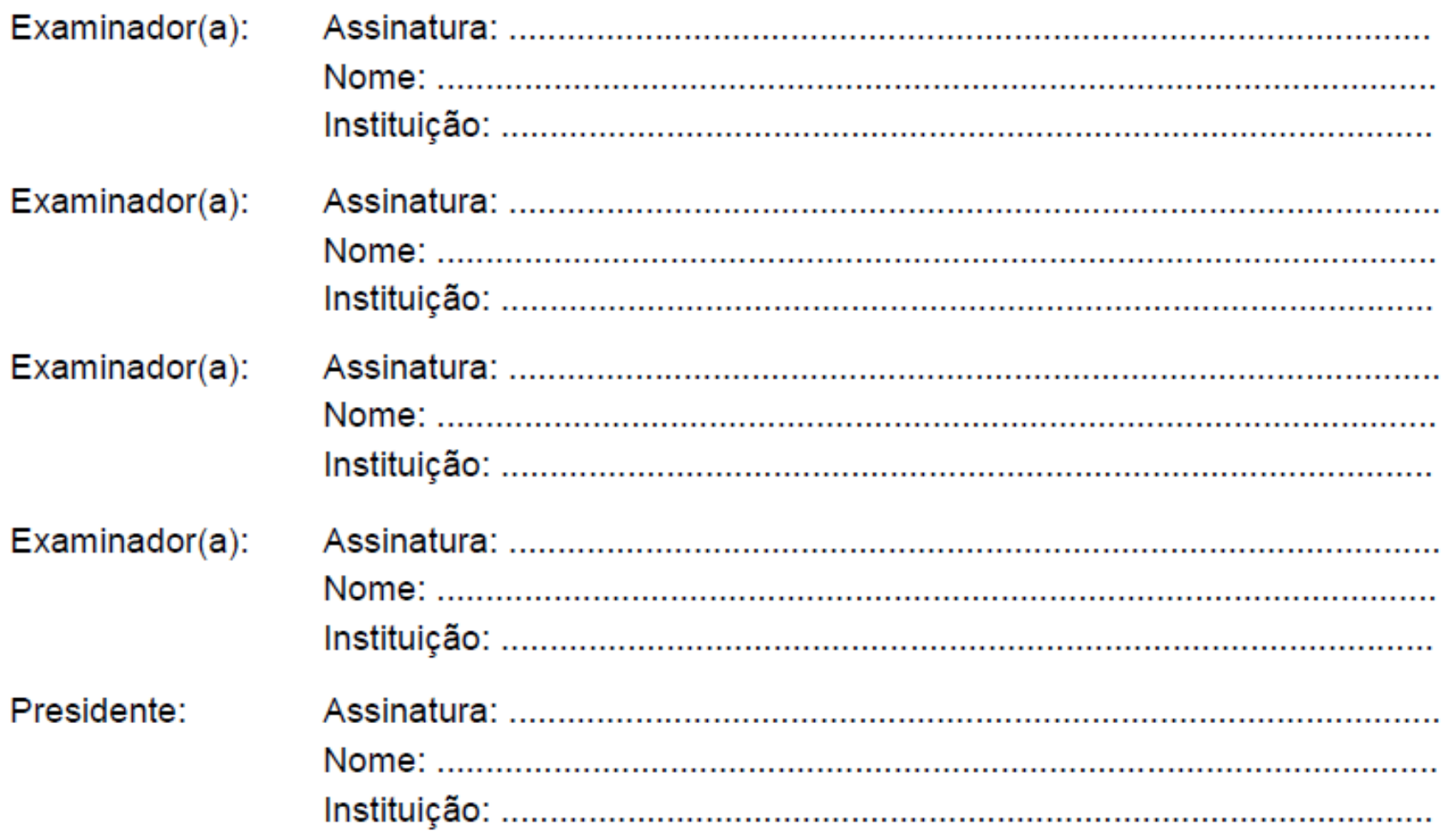




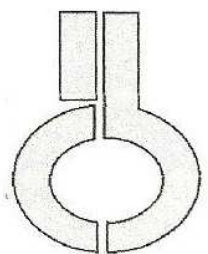

UNIVERSIDADE DE SÃO PAULO

INSTITUTO DE CIÊNCIAS BIOMÉDICAS

Cidade Universitária "Armando de Salles Oliveira"

Av. Prof. Lineu Prestes, 2415 - cep. 05508-000 São Paulo, SP - Brasil

Telefone :(55) (11) 3091.7733 telefax : (55) (11) $3091-7438$

e-mail: cep@ icb.usp.br

\section{PARECER 851/CEP}

São Paulo, 25 de agosto de 2008.

Prezada Senhora,

Atendendo sua solicitação, a Comissão de Ética em Pesquisas com Seres Humanos do $I C B$, em sua $87^{a}$ reunião realizada em 25.08.08, analisou o projeto de sua responsabilidade intitulado: "Estudo da resposta anticórpica materna aos ácaros D. pteronyssinus, B tropicallis e T. putrescentiae e sua transferência passiva ao bebê via passagem transplacentária e aleitamento materno".

Informo a V.Sa. que, após análise e discussão, o referido projeto foi aprovado por esła Comissão.

Lembramos que cabe ao pesquisador elaborar e apresentar a este Comitê, relatórios anuais (parciais ou final), de acordo com a resolução 196/06 do Conselho Nacional da Saúde, item IX.2 letra c.

O primeiro relatório deverá ser encaminhado à Secretaria deste CEP em 25 de agosto de 2009.

Atenciosamente,

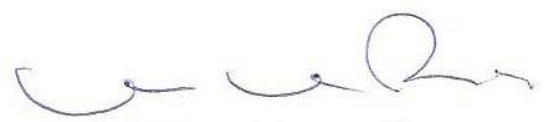

Prof. Dr. LUIZ VICENTE RIZZO

Coordenador da Comissão de Ética em Pesquisas com Seres Humanos - ICB/USP

IIma. Sra.

PATRÍCIA MACCHIAVERNI

Departamento de Imunologia

Instituto de Ciências Biomédicas -USP 
Dedico esta tese a meus pais Nelson e Luzita, pelo apoio, encorajamento, amor e exemplo de pessoa e de profissionalismo que formaram os alicerces de minha história. São eles os responsáveis por minha personalidade e interesse e dedicação ao estudo. 
Aos meus irmãos Nelson, Luzita e Luciana que, cada um à sua maneira, me incentivaram e permitiram que a concretização deste trabalho fosse possível. 
Ao amor de minha vida, companheiro, marido e amigo, Walter Eduardo, por acreditar em meu potencial e apoiar meus sonhos, sempre com otimismo e bom humor mesmo nos muitos momentos de dificuldade e incertezas. 
Ao meu querido filho que me surpreende a cada dia mostrando-me a imensidão do amor.... Nunca, nem mesmo em meus sonhos, Pedro, imaginaria que tivesse a sorte de compartilhar esta caminhada com uma pessoa tão linda, por dentro e por fora, e com uma generosidade e percepção tão aguçada do mundo, que me ensina o que realmente tem valor nesta vida. 


\section{AGRADECIMENTOS}

Ao Prof. Dr. Antônio Condino Neto, meu muito obrigado pela orientação, conselhos e paciência ao longo de todos esses anos.

À Profa. Dra. Valérie Verhasselt por me apresentar a imunologia de uma forma encantadora e por sua (quase que inacreditável) disposição e otimismo. Por ela tenho enorme admiração e gratidão, que vão além do conteúdo científico apresentado nesta tese. Mesmo distante, a amizade estará sempre ao meu lado.

À minha amiga, Christina Arslanian, não só pelo indispensável auxilio técnico, mas, principalmente, pelo carinho e cuidado constantes.

À Akila Rekima por me receber de braços abertos e, muito pacientemente, me guiar durante os meses que estive no laboratório "Tolérance Immunitaire"-Université de Nice Sophia-Antipolis, France.

Ao Prof. Dr. Momthchilo Russo, pelo auxílio científico e por possibilitar minha colaboração com o instituto Francês.

Aos meus grandes amigos Mateo Pedroza e Carolina Prando, pelo belo exemplo de persistência, determinação e invejável competência.

Ao meu amigo Josias Brito, que me acompanhou e apoiou em todos os momentos de incertezas.

Aos queridos familiares da Valérie: Laetittia, Ludovic, Marrius e Gauthier, que me acolheram de uma maneira deliciosa e permitiram que eu tivesse uma família nos períodos que viajei sozinha à França.

Aos meus colegas de laboratório de Imunologia em Humanos: Paulo Vitor Soeiro, Walmir Cutrin, Éric Hainer, Taj Ali Kan, Angela Falcai, Marilia Kanegae, Edgar Borges, Marina Wall, Núria Zurro, Otavio Marques, Lena Schimke, Stefanie Klaver e José Albuquerque pelo companheirismo, apoio e agradáveis momentos de convivência.

Aos meus colegas do Institut National de Santé et de la Recherche Médicale Anne, Julie, Emilie, Samah e Mathilde, pelos aprendizados, risadas e momentos compartilhados na linda Côte D'Azur.

À Prof. Dra Meri Tulic, que apesar de pouco tempo de convívio, foi muito importante para meu crescimento científico que com quem pretendo continuar aprendendo e colaborando.

Aos meus queridos amigos Daniela e Ricardo, com quem tive o privilégio de conviver no período que estive na França e compartilhar experiências e angústias comuns a todos os pesquisadores Brasileiros que buscam crescimento profissional em um País desconhecido. 
Às professoras Profa. Dra.Sônia Jancar, Dra. Patricia Palmeira e Profa. Dra. Solange Carbonare que, como membros da banca de qualificação, contribuíram com importantes e enriquecedoras sugestões.

À gerente de projetos Silvana Luchini pela ajuda, sempre eficiente em todos os momentos que precisei. Uma pessoa indispensável para todos do laboratório.

À Rosana Prisco pela atenção e auxílio na análise estatística.

Ao governo do Estado de São Paulo e à Fundação de Amparo a Pesquisa do Estado de São Paulo (FAPESP); ao Institut National de Santé et de la Recherche Médicale (INSERM) e à NESTLÉ pelo apoio financeiro.

À Maternidade de Campinas por permitir a coleta de colostro e sangue das doadoras.

Aos médicos, residentes e enfermeiras da obstetrícia da Maternidade de Campinas, pelo auxilio na coleta e triagem das voluntárias.

Às mães que prontamente se dispuseram a doar seu sangue e colostro.

À Silvana S Dalgé, pela eficiência e descontração na coleta das amostras de sangue e colostro.

Ao Dr João Carlos Mori IPI-ASAC Brasil que forneceu o extrato de ácaro para realização dos testes.

Aos funcionários da secretaria do Departamento de Imunologia, em especial à Eni, pelo desempenho e dedicação em todos os momentos em que precisei.

Aos colegas e professores do programa de pós-graduação em Imunologia, essenciais em minha formação como pesquisadora. 
A tarefa não é tanto ver aquilo que ninguém viu, mas pensar o que ninguém ainda pensou sobre aquilo que todo mundo vê.

Arthur Shopenhauer 


\section{RESUMO}

Macchiaverni P. Alérgenos ambientais são transferidos ao bebê via placenta e colostro na presença de anticorpos específicos. [tese (Doutorado em Imunologia)]. São Paulo: Instituto de Ciências Biomédicas, Universidade de São Paulo; 2012.

Diversos estudos em modelo animal indicam claramente que a transferência materna de lgG alérgeno-específica via placenta ou leite previne a resposta alérgica na prole. A presença de aero-alérgeno juntamente com TGF- $\beta$ no leite, também mostrou proteger os camundongos amamentados contra a asma por induzir tolerância oral. Além disso, estudos em humanos e em modelos experimentais mostram que a IgA desempenha importante papel imunorregulatório. No entanto, pouco se sabe sobre a transferência de $\lg G$ e $\lg A$ específica a alérgenos ambientais em humanos e a presença de aero-alérgenos no leite materno nunca foi demonstrada. Dermatophagoides pteronyssinus (Der p) e Blomia tropicalis (Blo t) são ácaro presentes na poeira domiciliar e representam importante fonte de alérgenos responsáveis por desencadear alergias respiratórias em crianças e adultos. Neste estudo, investigamos se as mães podem transferir aos seus filhos alérgenos ambientais e anticorpos específicos durante a gestação e período de amamentação. Especificamente, investigamos se alérgenos de Der $p$ e Blo $t$, assim como seus anticorpos específicos, podem ser detectados no cordão umbilical e/ou colostro, e se o estado atópico materno exerce alguma influência na concentração detectada.Para isso, analisamos a transferência materna em uma coorte de 91 amostras pareadas de soro materno, colostro e cordão umbilical. O presente estudo demonstrou que tanto o Der $p 1$ como Blo t 5 podem estar presentes em amostras de colostro e cordão umbilical e identificou a atopia materna como fator crítico para o aumento de IgG alérgeno-específica nestes compartimentos. No cordão umbilical, a maior diferença entre mães atópicas e não atópicas foi observada para a IgG4. Os alérgenos Der p 1 e Blo $t 5$ estavam presentes $30 \%$ e $9,6 \%$ das amostras, respectivamente, sem correlação com o estado atópico materno ou concentração de anticorpos específicos no cordão umbilical. No colostro, a IgA específica foi detectada em todas as amostras em concentrações independente da atopia materna. Os alérgenos Der p 1 e Blo t 5 estavam presentes $68 \%$ e $41 \%$ das amostras, respectivamente. Apenas para o alérgeno Der $p 1$ a concentração foi maior no colostro de mães atópicas e apresentou correlação com os níveis de anticorpos lgG específicos. Tendo em vista as evidências em modelo animal e a importância da prevenção primária da alergia, acreditamos que nosso estudo represente o primeiro e fundamental passo para esclarecer o papel dos alérgenos ambientais e seus anticorpos específicos no inicio da vida, assim como seu efeito na manifestação alérgica.

Palavras-chave: Alergia. Passagem transplacentária. Amamentação. Cordão umbilical. Alérgenos ambientais. 


\begin{abstract}
Macchiaverni P. Airborne allergens can be transferred to the newborn through placenta and colostrum in the presence of maternal specific antibodies. [Ph. D. thesis (Immunology)]. São Paulo: Instituto de Ciências Biomédicas, Universidade de São Paulo; 2012
\end{abstract}

Experimental data in rodents indicate that maternal allergen-specific IgG transferred by placenta and/or breastfeeding prevents allergic sensitization in the progeny. It was also demonstrated that airborne allergens in the presence of TGF $-\beta$ in the milk protects breastfeed mice from asthma development, because of the induction of oral tolerance. Animal and human studies indicate that $\lg A$ can exert an immunoregulatory role. In humans, only a few studies have demonstrated the presence of $\lg G$ or $\lg A$ specific for food and respiratory antigens in cord blood or breast milk, respectively. To date, no study has demonstrated the transfer of respiratory allergens by breast milk. The house dust mites Dermatophagoides pteronyssinus $(\operatorname{Der} p)$ and Blomia tropicalis $(B / o t)$ are indoor respiratory allergens that represents a major cause of allergic asthma and others respiratory allergies. In this study, we investigated whether mothers can provide to their children allergens and antibodies specific for Der $p$ and Blo $t$. In particular, we assessed whether Der $p$ and Blo $t$ allergens, as well as specific antibodies were detected in cord blood and/ or colostrums and whether maternal atopic status had any influence on the amount detected. For this purpose, we analyzed the maternal transfer in a cohort of 91 paired samples of maternal blood, colostrums and umbilical cord blood. Our study indicates that Der p 1 and Blo t 5 can be found in both cord blood and colostrums and identifies maternal atopy as a critical factor for increased levels of allergen-specific IgG in these compartments. In the cord blood the biggest difference between atopic and non atopic mothers was observed for lgG4. The allergens Der $p 1$ and Blo $t 5$ were present in $30 \%$ and $9,6 \%$ of the samples, respectively, and no correlation with maternal atopic status. In colostrums specific IgA was found in all colostrums samples and levels were independent of maternal atopic status. The allergens Der $p$ 1 and Blo $t 5$ were present in $68 \%$ and $41 \%$ of samples, respectively. Only for Der $p$ 1 the concentration was higher in atopic mothers and correlated with Der $p$ specificIgG levels in colostrums. In view of the increasing evidence from animal models and importance of neonatal prevention of allergy, we believe that our study would be a timely and necessary way to elucidate the role of allergen-specific $\lg$ in early life and its effect on allergy development.

Keywords: Allergy. Placental transfer. Breastfeeding. Umbilical cord. Airborne allergens. 


\section{LISTA DE ILUSTRAÇÕES}

Figura 1- Potencial alergênico dos ácaros da poeira domiciliar (HDM). 27

Figura 2- Ativação das células do sistema imunológico inato pelos ácaros da poeira domiciliar (HDM) .................................................... 28

Figura 3- Passagem transplacentária da IgG...................................... 32

Figura 4- Tolerância mediada pela transferência de antígenos via leite materno

Figura 5- Possível influência materna na indução de tolerância no recém-nascido

Figura 6- Concentração de IgG anti-Der $p$ no soro materno e no cordão umbilical

Figura 7- Concentração de IgG anti-Blo $t$ no soro materno e no cordão umbilical

Figura 8- Concentração de IgG1, IgG2, IgG3 e lgG4 anti-Der $p$ no grupo de mães atópicas e não atópicas

Figura 9- Concentração de IgG1, IgG2, IgG3 e lgG4 anti-Der $p$ no soro materno e no cordão umbilical

Figura 10- Taxa de passagem transplacentária para cada subclasse ... 66

Figura 11- Concentração de $\lg G 1, \lg G 2, \lg G 3$ e $\lg G 4$ anti-Blo $t$ no grupo de mães atópicas e não atópicas

Figura 12- Concentração de IgG1, IgG2, IgG3 e lgG4 anti-Blo $t$ no soro materno e no cordão umbilical

Figura 13- Taxa de passagem transplacentária 70

Figura 14- Concentração de Der $p 1$ e Blo $t 5$ no cordão umbilical 72

Figura 15- Concentração de Der $p 1$ e Blo $t 5$ no cordão umbilical ....... 73

Figura 16- Concentração de IgM específica no cordão umbilical ......... 74

Figura 17- Concentração de IgA total e anti-Der $p$ no colostro de mães atópicas e não atópicas

Figura 18- Concentrações de TGF-beta no colostro …………............ 76

Figura 19- Concentração de IgG anti-Der $p$ no colostro ....................... 77

Figura 20-Concentração de $\lg A$ total e anti-Blo $t$ no colostro de mães atópicas e não atópicas

Figura 21- Concentrações de TGF-beta no colostro 
Figura 22- Concentração de IgG anti-Blo $t$ no colostro 80

Figura 23- Concentração de alérgeno ambiental no colostro. 81

Figura 24- Concentração de alérgeno ambiental no colostro 83

Figura 25- Concentração de alérgeno ambiental no colostro e cordão umbilical 83

Figura 26- Concentração de $\operatorname{Der} p 1$ no colostro e leite 84 


\section{LISTA DE TABELAS}

Tabela 1- Características dos alérgenos Dermatophagoides pteronyssinus (Der $p$ ) e Blomia tropicalis (Blo $t$ ).

Tabela 2- Subclasses das IgGs: Concentração e características.

Tabela 3- Classificação das concentrações de IgE específica segundo

CapSystem ${ }^{\circledR}$ Pharmacia.

Tabela 4- Diluições utilizadas no ELISA para quantificação de anticorpos específicos aos ácaros Der $p$ e Blo t.

Tabela 5- Diluições utilizadas no ELISA para quantificação dos alérgenos Der $p 1$ e Blo $t 5$

Tabela 6- Características da população estudada.

Tabela 7- Concentração de IgG total e anti-Der p no soro materno e de cordão umbilical.

Tabela 8- Concentração de IgG total e anti-Blo t no soro materno e de cordão umbilical

Tabela 9- Concentração de IgG1, IgG2, IgG3 e IgG4 anti-Der $p$ no soro materno e no cordão umbilical.

Tabela 10- Concentração de IgG1, IgG2, IgG3 e IgG4 anti-Blo t no soro materno e no cordão umbilical.

Tabela 11- Concentração de Der p 1 e Blo $t 5$ no cordão umbilical. 73

Tabela 12- Concentração de IgA total, IgA anti-Der $p$ e IgG anti-Der $p$ no colostro

Tabela 13- Concentração de $\lg A$ total, IgA anti-Blo te $\lg G$ anti- Blo t no colostro 80

Tabela 14- Concentração de Der p 1 e Blo $t 5$ no colostro 82

Tabela 15- Concentração de Der $p 1$ no leite humano. 84

Tabela 16- Concentração de Der $p 1$ em amostras de leite humano. 85 


\section{LISTA DE ABREVIATURAS E SIGLAS}

APC: Células apresentadoras de antígeno.

Bet v1: Alérgeno 1 do pólen.

Blo t: Ácaro Blomia tropicalis.

CD23: receptor FceRII de baixa afinidade para lgE.

CLRs : Receptores de lectina tipo $\mathrm{C}$, do inglês $C$-type lectin receptors.

DAMPs: Padrões de sinais de perigo associados ao dano celular, do inglês Damage associated molecular pattern molecules.

DC: Célula dendrítica, do ingles dendritic cells.

Der f: Ácaro Dermatophagoides farinae.

Der p: Ácaro Dermatophagoides pteronyssinus.

FcRN : receptor Fc neonatal.

FcعR: receptor para $\lg \mathrm{E}$.

Fel d 1: Alérgeno 1 do gato.

GALT: tecido linfóide associado ao trato gastrointestinal

GATA3: Fator de transcrição, do inglês GATA binding protein 3

Ig: Imunoglobulina

IL: Interleucina

LPS: Lipopolissacarídeo

LT: Linfócito T

MHC: Molécula do complexo de histocompatibilidade principal, do ingês major histocompatibility complex

NALT: tecido linfoide associado à mucosa nasal

OVA: Ovalbumina

PAMPs: Padrões moleculares associados a patógenos, do ingês pathogenassociated molecular pattern molecules.

PARs: Receptores ativados por protease, do inglês protease-activated receptors.

PRP: Polirribosil ribitol fosfato

PRRs: Receptores de reconhecimento de padrões, do inglês pattern recognition receptors

s-Ig: Imunoglobulina secretória

TGF: Fator de transformação do crescimento, do ingês inglês transforming growth factor 
Th: Linfócito T auxiliar, do inglês $T$ helper

TLR: Receptores semelhantes ao tol, do inglês Toll-like receptors

TNF: fator de necrose tumoral, do inglês tumor necrosis factor homology 
1 INTRODUÇÃO

1.1 Alergia: Prevalência e incidência ...................................................... 22

1.2 Ácaros da poeira domiciliar (HDM) representam a principal fonte de

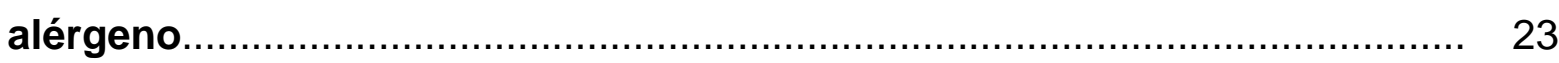

1.3 Influência materna na fisiopatologia das doenças alérgicas................. 29

1.3.1 Período pré-natal..................................................................... 29

1.3.2 Período pós-natal............................................................................ 36

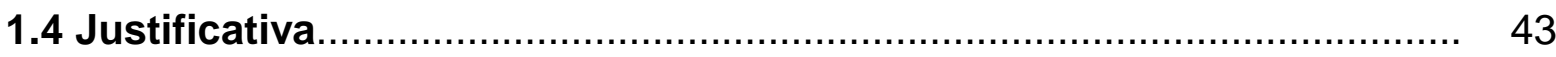

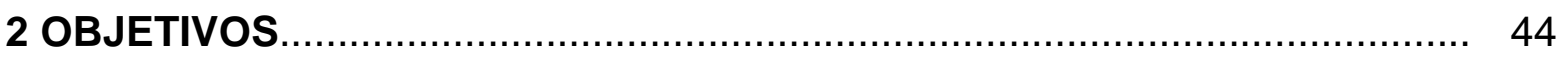

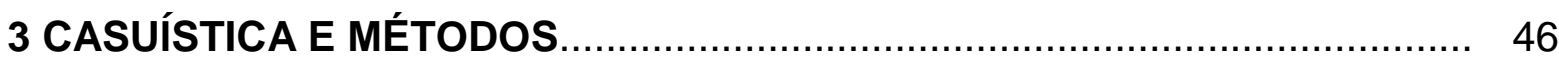

3.1 Seleção da casuística.................................................................... 47

3.2 Obtenção das amostras............................................................. 48

3.3 Quantificação de IgE sérica específica................................................ 49

3.4 Quantificação de IgE sérica total .................................................... 50

3.5 Quantificação de Ig G sérica total................................................... 50

3.6 Quantificação de IgA total no colostro............................................. 51

3.7 Quantificação de anticorpos específicos aos ácaros Dermatophagoides pteronyssinus e Blomia tropicalis .............................. 51

3.8 Quantificação dos antígenos Der p 1 e Blo t 5................................... 54

3.9 Quantificação de TGF-beta no colostro............................................. 55

3.10 Análise estatística ....................................................................... 55

3.11 Taxa de passagem transplacentária............................................... 56

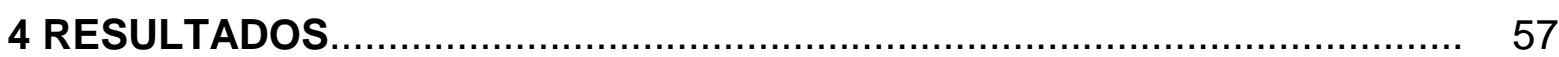

4.1 Características da população estudada ........................................... 58

4.2 Passagem transplacentária de anticorpos alérgenos-específicos.......... 60

4.3 Transferência de alérgenos via passagem transplacentária ................. 71

4.4 Presença de IgM anti-Der $\boldsymbol{p}$ e IgM anti-Blo $\boldsymbol{t}$ no cordão umbilical........... 74

4.5 Transferência de anticorpos alérgenos-especificos via aleitamento

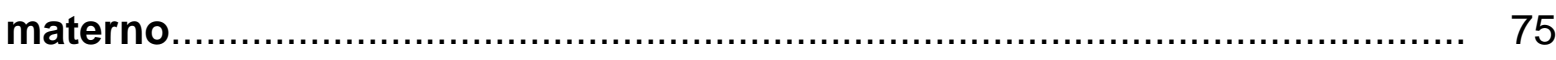

4.6 Passagem de alérgenos livres via aleitamento materno ........................ 81

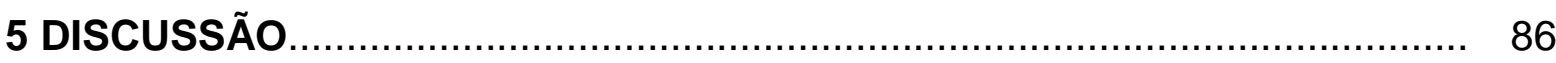


6 CONCLUSÃO.

REFERÊNCIAS

APÊNDICE A - Macchiaverni, P. Scandinavian Journal of Immunology, 2011

APÊNDICE B - Macchiaverni P, Revue Française d'Allergologie, 2011...... 129

APÊNCIDE C - Questionário e termo de consentimento aplicado.

ANEXO A - Níveis de anticorpos IgE totais e específicos e dados da mãe e do recém-nascido.

ANEXO B - Níveis de IgG totais e IgG, IgG1, IgG2, IgG3 e IgG4 específicos em amostras pareadas de soro materno (mãe) e cordão umbilical (RN)...... ANEXO C - Níveis de IgA total, IgA e IgG específica, TGF-beta e alérgenos Derp 1 e Blo 5 no colostro.

ANEXO D - Níveis de IgM específica e alérgenos no cordão umbilical. 158 ANEXO E - Padrão de reatividade das imunoglobulinas IgG e $\lg A$ frente aos extratos totais de Der $p$ e Blo $t$ em amostras pareadas de colostro, soro materno e soro de cordão umbilical. 


\section{INTRODUÇÃO}




\subsection{Alergia: prevalência e incidência}

O primeiro relato sobre alergia aparece no início do século 19 e refere-se à febre do feno, atualmente conhecida como rinite alérgica. Dependendo do órgão onde se manifestam, as reações alérgicas podem ser respiratórias, alimentares ou dermatológicas; todas podendo ocorrer de forma individual ou em combinação (Holt et al., 2005).

De acordo com o recente International Study of Asthma and Allergies in Childhood (The Global Asthma Report, 2011), estima-se que 300 milhões de pessoas, destas $2 / 3$ crianças, sofrem com a asma e que mais 100 milhões serão afetadas até 2025. A prevalência de doenças alérgicas tem aumentado consideravelmente ao longo dos últimos anos, principalmente nos países em desenvolvimento. Com base nessa observação, Asher e colaboradores lançaram em 1991 o estudo ISSAC (International Study of Asthma and Allergies in Childhood), que consiste em um estudo epidemiológico universal e único para investigar a incidência de asma, rinite e eczema em crianças e adolescentes de 6 a 14 anos de idade (Chong Neto et al., 2012).

Este estudo avaliou crianças e adolescentes em diversos países. O Brasil está entre os países que registraram maior aumento, juntamente com Argentina, Paraguai e França (Björkstén et al., 2008). Após 3-5 anos de acompanhamento clínico, os pesquisadores concluíram que a prevalência tanto de asma como rinoconjuntivite vem crescendo paulatinamente (cerca de $0,13 \%$ e 0,06\% ao ano nas crianças e adolescentes, respectivamente). Apesar deste aumento ser bastante variável entre os países e entre as diferentes regiões de um mesmo país, atualmente atinge de 10 a 20\% da população europeia, 30\% dos brasileiros e chega a 40\% na Austrália (Björkstén et al., 2008; Chong Neto et al., 2012; Solé et al., 2007).

O custo do tratamento da asma é muito alto, pois o paciente necessita de assistência diversas vezes no decorrer da vida. Os principais custos diretos estão voltados para cuidados hospitalares e compra de produtos farmacêuticos. A hospitalização resulta ainda na perda de produtividade devido à falta no trabalho ou escola e indiretamente também representa um custo para a sociedade (Bousquet et al., 2005). A cronicidade da doença e ausência de cura no tratamento faz com que a 
prevenção primária seja prioridade na saúde publica, justificando a urgência na identificação dos fatores de risco e de prevenção da alergia.

\section{2 Ácaros da poeira domiciliar (HDM) representam a principal fonte de alérgeno}

Fatores ambientais são apontados como responsáveis pelo aumento na incidência de doenças alérgicas respiratórias. Uma das hipóteses é a de que atualmente a população passa grande parte do tempo em ambientes fechados e consequentemente é mais exposta à poeira domiciliar (Chew et al., 1999). A poeira contém componentes orgânicos de diversas origens, todos possíveis de serem inalados: esporos de fungos, pólen, fibras vegetais, bactérias, restos de alimentos, escamas de tecido epitelial humano e pequenos animais. Os ácaros correspondem a aproximadamente 90\% destes componentes (Bronswijk et al., 1981) e representam um dos principais fatores etiológicos da alergia. (Platts-Mills et al., 1992; Schwarze et al., 1998).

Os ácaros são pequenos artrópodes que pertencem a subclasse taxonômica Acari onde mais de 50.000 espécies já foram identificadas. Estão presentes em toda parte: na terra, no ar e até mesmo na água. Mas são os presentes na poeira domiciliar os responsáveis por causar alergias e desencadear crises de rinite, asma e conjuntivite (Nadchatram, 2005).

O primeiro documento que relacionou doenças alérgicas respiratórias com ácaros foi publicado em 1967. Em 1968 Reindert Voorhorst demonstrou que a espécie Dermatophagoides pteronyssinus (Der $p$ ) representava a principal fonte de alérgeno presente na poeira domiciliar e que poderia ser identificado no mundo inteiro (Spieksma et al., 2004). A partir destes achados os estudos envolvendo Der $p$ e manifestações alérgicas não pararam e o número de publicações envolvendo este tema em 2012 já passa de 5000 (segundo busca no www.pubmed.com). Outro importante ácaro presente na poeira domiciliar é o da espécie Blomia tropicalis (Blo t). Apesar do Blo $t$ representar um importante alérgeno nos países tropicais e subtropicais como Brasil, Porto Rico e Colômbia (Fernández-Caldas et al., 1993; Montealegre et al., 1997; Nadchatram et al., 2005; Rizzo et al., 1997; Serravalle et al., 1999) ainda é muito pouco estudado, com apenas 200 publicações em 2012 (segundo busca no www.pubmed.com). 
Em nosso meio a exposição aos ácaros na poeira domiciliar é alta. Prova disso é que em poucos meses de uso os colchões abrigam de centenas de milhares a milhões de diversas espécies desses animais (Oliveira et al., 1999)

$\mathrm{Na}$ cidade de São Paulo, Arruda et al. (1991) observaram que as espécies Der p e Blo t representavam $50 \%$ e $26 \%$, respectivamente, dos alérgenos presentes na poeira domiciliar. Na região de Campinas- SP, Oliveira e cols. (1999) encontraram em média 3.254 ácaros na parte inferior dos colchões de 124 indivíduos com quadro clínico sugestivo de atopia, sendo o ácaro Der $p$ a principal espécie. Amostras de poeira de sofás e tapetes da sala de estar e do quarto de dormir também apresentaram alta concentração acarina, onde as espécies prevalentes foram Der p e Blo $t$ (Binotti et al., 2003, 2005). No sul do país (Londrina PR), as espécies Der p e Blo trepresentam $72 \%$ e $84 \%$ do total de ácaros presentes em berços e camas, com média de 289,9 \pm 136,7 e 875,0 \pm 183,6 ácaros/g de poeira, respectivamente (Silva et al., 2005 a,b). Além de estarem presentes em altas concentrações, em todo Brasil as espécies Der $p$ e Blo $t$ são os principais indutores da sensibilização alérgica e responsáveis pelos maiores índices de positividade dos testes cutâneos (Almeida et al., 2006; Geller et al., 1996; Medeiros et al., 1997; Sarinho et al., 1996).

\section{a) Indução da alergia por ácaros}

Em dez semanas um ácaro irá produzir em média 2000 partículas fecais e um número ainda maior de enzimas parcialmente digeridas que poderão ser facilmente inaladas e depositadas nas vias aéreas (van Bronswijk, Sinha, 1971). A reação de hipersensibilidade a aero-alérgenos inicia-se após inalação e entrada do alérgeno através da membrana da mucosa respiratória (Schwarze et al., 1998). Este será capturado por células dendríticas, que atuarão como apresentadoras de antígeno profissionais (APCs), apresentando peptídeos selecionados na molécula de MHC II aos linfócitos $T$ naïve no linfonodo. A apresentação dos alérgenos direciona a diferenciação dos linfócitos $T$ para subtipo $T$ helper $2\left(T_{H} 2\right)$, caracterizado por secretar as citocinas IL-4, IL-5, IL-13 e IL-9, mediado pelo fator de transcrição GATA3 (Comoy et al., 1998; Georas et al., 2005). A IL-5 atua nos eosinófilos elevando seu número e promovendo sua ativação, a IL-9 no recrutamento de 
mastócitos e a IL-4 e IL-13 desempenham papel crucial na mudança de classe para IgE nos linfócitos B (Holgate et al., 2008).

Quando um indivíduo atópico, sensibilizado a um alérgeno em particular o reencontra, a ligação cruzada do antígeno a duas moléculas de lgE ligadas ao receptor de alta afinidade (FcعRI) na membrana dos mastócitos desencadeia sua ativação. A ativação dos mastócitos mediada pela $\lg E$ tem como consequência a degranulação e síntese de mediadores inflamatórios poucos minutos após o contato com o alérgeno. Entre os mediadores temos a histamina, leucotrienos e citocinas. Estes promovem o aumento da permeabilidade vascular, contração da musculatura lisa e produção de muco. A exposição repetida a aero-alérgenos estimula a liberação de quimiocinas por mastócitos e outros tipos celulares, responsáveis por uma importante cascata inflamatória, caracterizada por grande número de eosinófilos, basófilos e linfócitos $T_{H} 2$ na mucosa nasal, brônquica e tecidos marginais (Bochner et al., 2005; Gould et al., 2008).

O aumento e estabelecimento da inflamação alérgica não são dependentes apenas da resposta imune adaptativa mediada pelos linfócitos $T_{H} 2$. Ela também é fortemente influenciada por células da imunidade inata, diretamente ativadas pelos alérgenos ou compostos associados a eles (Gregory, Lloyd, 2011; Jacquet 2011).

\section{b) Alérgenos presentes nos ácaros da poeira domiciliar}

O potencial alergênico dos ácaros está relacionado à composição de seu próprio corpo, de seus dejetos ou ainda à produtos derivados de bactérias e fungos, frequentemente encontrados em associação à eles (figura 1).

Os epítopos imunogênicos presentes nos ácaros são proteínas com diversas funções biológicas, classificadas em grupos de acordo com sua composição química, homologia e peso molecular (tabela 1). Apesar do grande número de proteínas potencialmente alergênicas já identificadas existem especificidades imunodominantes: As proteínas do grupo 1 e do grupo 2 são consideradas os principais alérgenos do ácaro Der p, pois são reconhecidas por mais de $80 \%$ dos pacientes sensibilizados. Em relação ao ácaro Blo $t$, além dos alérgenos do grupo 1 e grupo 2, a proteína do grupo 5 também representa um de seus alérgenos principais, reagindo com a $\operatorname{lgE}$ específica em $80-90 \%$ dos pacientes sensibilizados (Tsai JJ et al., 2003; Yi FC et al., 2005). 
Tabela 1- Características dos alérgenos Dermatophagoides pteronyssinus (Der p) e Blomia tropicalis (Blo t).

\begin{tabular}{clcc}
\hline $\begin{array}{c}\text { Alérgeno } \\
\text { (grupo) }\end{array}$ & Função biológica & \multicolumn{2}{c}{ Peso molecular (kDa) } \\
\cline { 3 - 4 } & Cisteína protease & Der $\boldsymbol{p}$ & Blo $\boldsymbol{t}$ \\
\hline 1 & MD-2 related lipid recognition domain & 24 & 39 \\
3 & Tripsina (serina protease) & 15 & - \\
4 & Alfa-amilase & 31 & - \\
5 & Função desconhecida & 60 & 56 \\
6 & Quimotripsina & 14 & 25 \\
7 & Binds lipopeptide polymyxin B & 25 & - \\
8 & Gutationa S-transferase & 27 & - \\
9 & Serina protease Colageonilica & 29 & - \\
10 & Tropomiosina & 36 & 33 \\
11 & Paramiosina & 103 & 110 \\
12 & Quitinase & - & 14 \\
13 & Lipocalina & - & - \\
14 & Apolipoforina & 177 & - \\
15 & Quitinase & - & 7 \\
19 & Quitinase & - & - \\
20 & Arginina quinase & - & - \\
21 & Função desconhecida & - & - \\
23 & Função desconhecida & 14 & \\
\hline
\end{tabular}

As informações foram modificadas dos artigos Gregory e Lloyd, 2011 e Jacquet 2011 e retiradas dos seguintes websites: www.allergen.org (site oficial para nomenclatura de alérgenos aprovada pela organização mundial da saúde e pela União Internacional das Sociedades de Imunologia); www.allergome.org (contém informações sobre as moléculas consideradas alergênicas) e www.meduniwien.ac.at/allergens/allfam (contém informações sobre a classificação dos alérgenos em famílias proteicas).

- não identificado

Muitos pesquisadores investigam se os alérgenos presentes nos ácaros possuem propriedades intrínsecas responsáveis por sua alergenicidade. Algumas características importantes já foram demonstradas e estão muito bem exploradas em ambas revisões, a de Gregory e Lloyd (2011) e a de Jacquet (2011); representadas pelas figuras 1 e 2 .

A atividade proteolítica é uma característica comum a vários alérgenos. Os ácaros da poeira domiciliar, em específico seus dejetos fecais, contêm diversas enzimas proteolíticas. O principal exemplo é o alérgeno do grupo 1 , uma cisteína protease homóloga a papaína presente em altas concentrações nas fezes do Der $p$. (Arlian e Platts-Mills, 2001; Stewart et al., 1994). Uma vez inalada, a enzima proteolítica é capaz de clivar proteínas que compõe as junções compactas localizadas entre as células epiteliais das vias aéreas, tais como a ocludina, claudina 
1 e ZO-1. Diante da quebra desta integridade, o alérgeno aumenta a permeabilidade brônquica, entra facilmente em contato com as APCs profissionais e facilita sua apresentação aos linfócitos T (LT) (Lambrecht, Hammad, 2012).

Figura 1- Potencial alergênico dos ácaros da poeira domiciliar (HDM). A figura ilustra os diversos alérgenos presentes na composição dos ácaros e associado a eles, capazes de ativar o sistema imunológico e iniciar a resposta inflamatória.

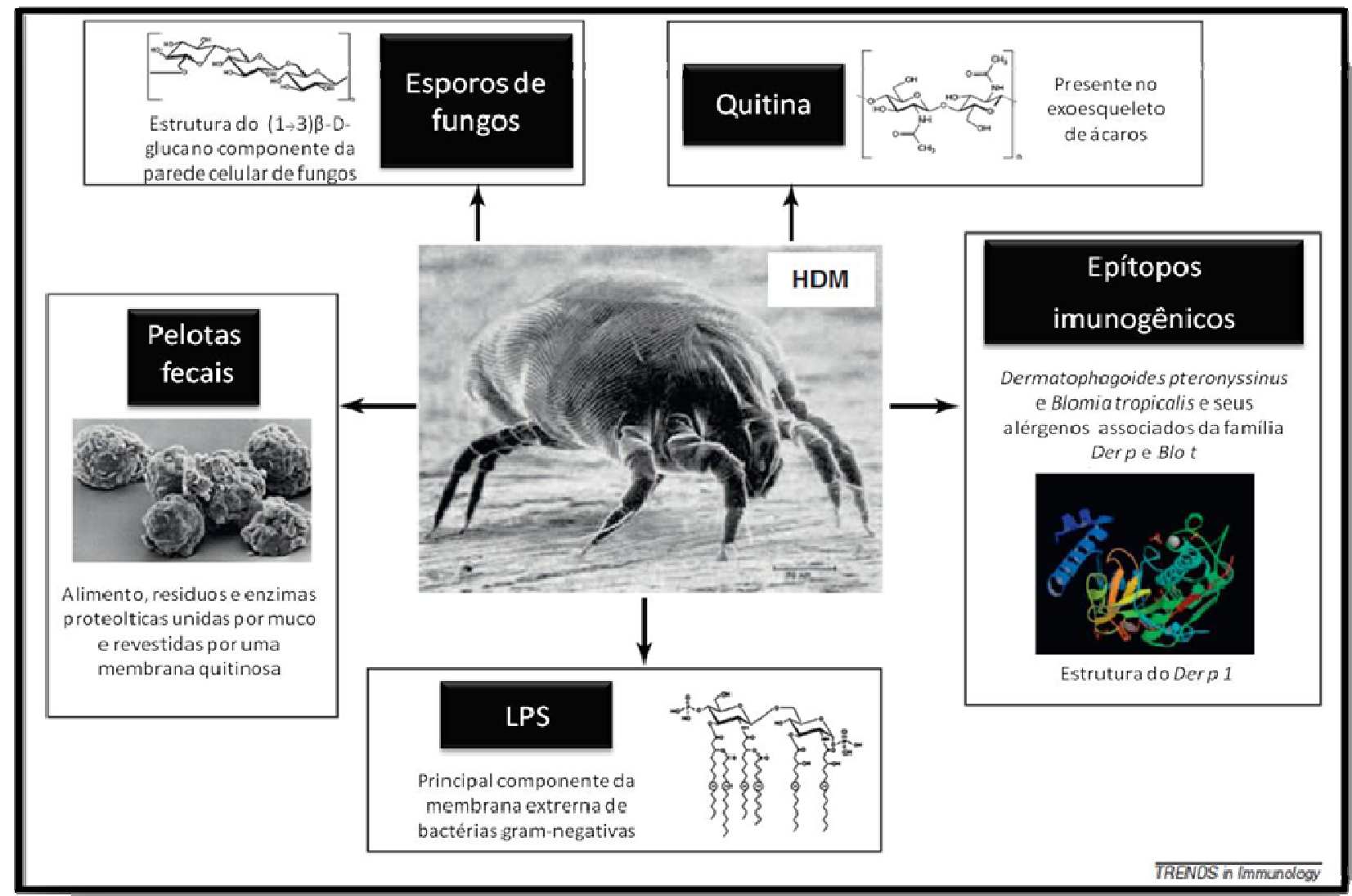

Fonte: Modificado de Gregory e Lloyd, 2011 e Jacquet, 2011.

Além do efeito direto nas junções compactas, as proteases reagem com PARs (receptores ativados por protease) e podem clivar outros receptores sensíveis à ação proteolítica; induzindo a inflamação e exacerbação do quadro alérgico (Gould et al., 2008; Gregory, Lloyd, 2011; Jacquet, 2011) (Figura 2). 
Figura 2- Ativação das células do sistema imunológico inato pelos ácaros da poeira domiciliar (HDM).

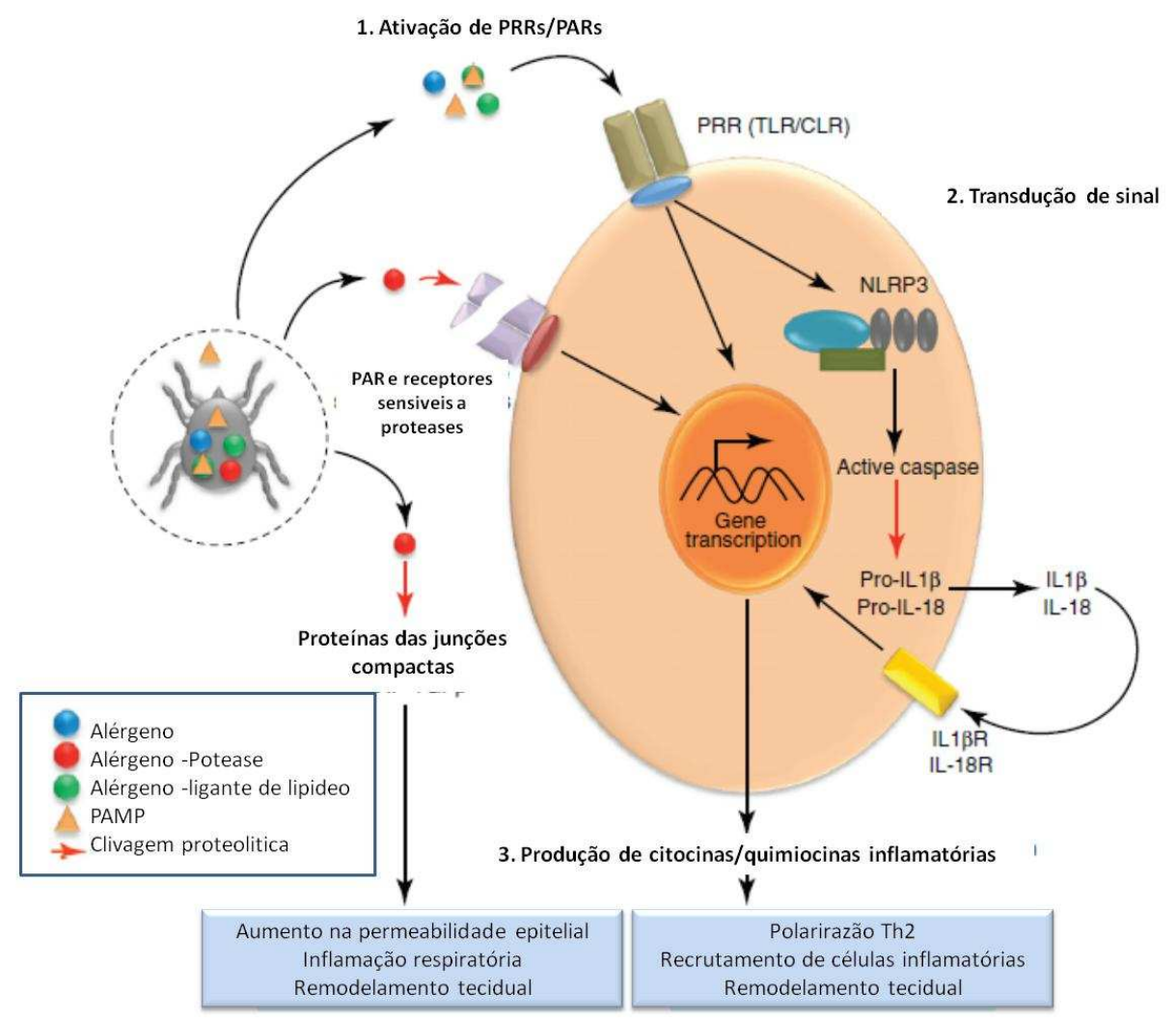

O sistema imunológico pode ser ativado e iniciar a resposta alérgica específica mediada por células $\mathrm{T}_{H} 2$ por diversas vias. Essas incluem a ligação de proteases e/ou padrões moleculares associados a patógenos (PAMPS) presentes nos alérgenos ou em associação aos ácaros. A quebra da integridade da barreira epitelial facilita a entrada e captura do alérgeno por células dendriticas (DC). A quebra dos receptores ativados por protease (PARs) e outros receptores sensíveis à ela, assim como a ativação dos receptores de reconhecimento de padrões (PRRs), como receptores tipo toll (TLRs) e receptores de lectina (CLRs), resultam na regulação positiva de citocinas e quimiocinas pró-inflamatórias e pró$\mathrm{T}_{\mathrm{H}}$ 2. Estas são liberadas para ativar e recrutar células inflamatórias e estimular a diferenciação de células $T_{\mathrm{H}} 2$.

Fonte: Modificado de Jacquet, 2011

Os alérgenos ainda apresentam propriedade adjuvante intrínseca. Ou seja, têm a capacidade de induzir tanto a resposta adaptativa como a resposta imune inata, auxiliando na polarização da resposta $T_{H} 2$ e ativação das vias de sinalização como dos receptores tipo-Toll 4 (Trompette, 2009). A ativação do sistema imune inato é possível, pois os padrões moleculares associados a patógenos (PAMPS) são frequentemente encontrados em associação aos ácaros em fungos ou bactérias. Estes incluem os lipopolissacarídeos (LPS), $\beta$-glucanos e os padrões de sinais de perigo associados ao dano celular (DAMPs) (figuras 1 e 2 ). 
No entanto, felizmente apenas uma pequena porção da população reage de maneira exacerbada a estes pequenos artrópodes, indicando que além das propriedades biológicas que as proteínas dos ácaros apresentam, outros fatores são de extrema importância para o desencadeamento e estabelecimento da alergia.

\subsection{Influência materna na fisiopatologia das doenças alérgicas}

Assim como em outras doenças, a manifestação alérgica é resultado de uma complexa interação entre predisposição genética e influências ambientais (Prescott, 2003). A herança genética, apesar de representar importante fator de risco para o estabelecimento do estado atópico na criança, dificilmente poderá ser modificada (Morel, Oriss, 1998; Scirica, Gold, 2007). Além disso, fatores ambientais são apontados como os grandes responsáveis pelo rápido e crescente aumento na prevalência de doenças alérgicas respiratórias. Neste contexto, é importante notarmos que a mãe fornece à criança tanto o componente genético como o componente ambiental no qual a criança irá se desenvolver durante a gestação e período de amamentação (Platts-Mills et al., 2003).

Na maioria dos casos a reação alérgica manifesta-se logo nos primeiros anos de vida. É também neste período que ocorre a programação e modulação do sistema imunológico da criança (Prescott et al., 2008). Assim, a natureza da exposição materna ao alérgeno em associação com um ambiente imunológico criado pela mãe no pré-natal e pós-parto imediato pode modular o desenvolvimento da resposta imune da criança quando esta for exposta ao alérgeno. Fica evidente, portanto, o grande interesse que diversos estudos têm em esclarecer quais são os fatores envolvidos na relação materno-infantil que podem diminuir o risco da criança em desenvolver alergia.

\subsubsection{Período pré-natal}

No período pré-natal a mãe se comunica com o feto através da passagem transplacentária. Muitas substâncias podem ser transportadas de maneira passiva ou ativa pela placenta. A habilidade de proteínas em atravessar a barreira transplacentária está associada ao seu peso molecular, solubilidade lipídica, polaridade, ionização, ligação a proteínas e fluxo sanguíneo materno e fetal. 
Moléculas de baixo peso molecular (<500Da) simplesmente difundem pela placenta enquanto que substâncias de alto peso molecular (ex. IgG 160KDa) necessitam de transporte ativo (Hurley et al., 2011).

\section{a) Passagem transplacentária de alérgenos}

Já foi demonstrado que células mononucleares de cordão umbilical podem proliferar após estímulo in vitro a alérgenos alimentares e ambientas (Jenmalm et al., 1997; Mariani et al., 1992). No entanto, a proliferação específica só ocorre em células de cordão umbilical estimuladas à antígenos cujas mães haviam sido expostas no período gestacional (Holt et al, 1985). Estes dados indicam que a mãe é capaz de transferir alérgenos ao feto e que virtualmente toda criança nasce com o sistema imunológico "primado" para responder aos antígenos que potencialmente entrará em contato ao nascimento (Hertz-Picciotto et al., 2007).

De fato, estudos mostram que de alérgenos alimentares (beta-lactoglobulina e ovalbumina) e ambientais (Der p 1, Bet v1 e Fel d 1) são capazes de atravessar a barreira transplacentária tanto na forma livre como em imunecomplexos (Casas et al., 2001; Holloway et al., 2000; Thorton, Vance, 2002). O que ainda não está estabelecido, no entanto, é se a exposição materna e intra-uterina ao alérgeno está ou não relacionada ao desenvolvimento da alergia na criança. Também não sabemos se o estado atópico materno influencia na passagem destes alérgenos.

\section{b) Passagem transplacentária de anticorpos}

A transferência de anticorpos maternos pela placenta é um fenômeno fisiológico de todo mamífero e essencial para a sobrevivência da espécie no meio extrauterino, pois fornece proteção ao recém-nascido nos primeiros meses de vida (Palmeira et al., 2012).

As primeiras evidências de transmissão de imunoglobulinas da mãe para o feto surgiram com Brambell e colaboradores há aproximadamente sessenta anos (Brambell et al., 1949). A passagem transplacentária inicia-se lentamente com aproximadamente 16 semanas de gestação. Entre 28-32 semanas os níveis de IgG sérica do recém-nascido alcançam $50 \%$ dos níveis maternos e começam a aumentar significativamente após 34 semanas de gestação (Simister, 2003). Recém-nascidos 
prematuros, portanto, não recebem os níveis adequados de anticorpos para a total proteção ao nascimento (Okoko et al., 2002).

Nos humanos, a lgG materna deve atravessar as barreiras histológicas da placenta até chegar à circulação fetal (sinciciotrofoblasto, citotrofoblasto e endotélio fetal). Estes tecidos expressam vários tipos de receptores para porção Fc da lgG, mas a passagem transplacentária de lgG ocorre essencialmente através do receptor Fc neonatal (FcRN).

\section{c) Receptor FcRN e a taxa de passagem transplacentária}

O Receptor FcRN é uma proteína formada de duas cadeias polipeptídicas: uma cadeia pesada similar a da molécula do complexo de histocompatibilidade principal de classe I (MHC-I) e outra cadeia leve que é a $\beta 2$-microglobulina (Simister et al., 1996). Este receptor é específico para porção Fc da lgG e liga-se com alta afinidade apenas em $\mathrm{pH}$ ácido $(\mathrm{pH}<6,5)$. Em humanos, foi primeiramente identificado na placenta e caracterizado como receptor responsável pela transferência maternofetal de anticorpos. No entanto, também pode ser encontrado em outros tecidos, estando envolvido na imunidade mediada por célula e na manutenção do tempo de meia vida das imunoglobulinas (Roopenian, 2007).

$\mathrm{Na}$ placenta o receptor FcRN é expresso no sinciciotrofoblasto. A passagem da IgG ocorre a partir do momento em que o sinciciotrofoblasto internaliza fluido materno em endossomos juntamente com as moléculas de IgG ali presentes. Os endossomos são gradualmente acidificados permitindo a forte ligação entre os anticorpos e os receptores FcRN, ambos protegidos contra a ação de enzimas lisossomais. A vesícula se funde à membrana na face fetal do sinciciotrofoblasto, a lgG é então dissociada pela ação do pH fisiológico e cai na circulação (Moraes-Pinto et al., 2001; Roopenian et al., 2007; Simister et al., 1997).

A concentração final de anticorpos na circulação neonatal para cada especificidade antigênica depende, além da concentração, da classe à qual a lgG materna pertence. Os níveis de lgG1 no recém-nascido geralmente excedem os maternos, os da lgG2 geralmente são mais baixos e os da lgG3 e lgG4 geralmente se igualam aos maternos. (Simister et al., 1997 e Simister, 2003). Essa observação deve estar relacionada à afinidade de ligação de cada subclasse ao receptor FcRN. No entanto, estudos sobre a eficiência das lgGs em atravessarem a placenta ainda 
mostram resultados controversos: Ensaio de perfusão in vitro da placenta indicou que a habilidade das IgGs em transpor a interface materno-fetal é maior para lgG4>lgG1>lgG3>lgG2 (Malek et al., 1995). Outros autores acreditam que a $\lg G 1 \mathrm{e}$ a IgG3 possuem maior eficiência, seguidas da lgG4 e IgG2 (Moraes-Pinto, 2001) ou ainda IgG1 e IgG4 seguidas pela IgG3 e IgG2 (Costa-Carvalho, 1996). Diferenças metodológicas podem explicar essas controvérsias, porém todos os estudos mostram que a lgG1 é transferida com alta eficiência e que a lgG2 apresenta menor taxa de passagem transplacentária.

Figura 3- Passagem transplacentária da IgG.

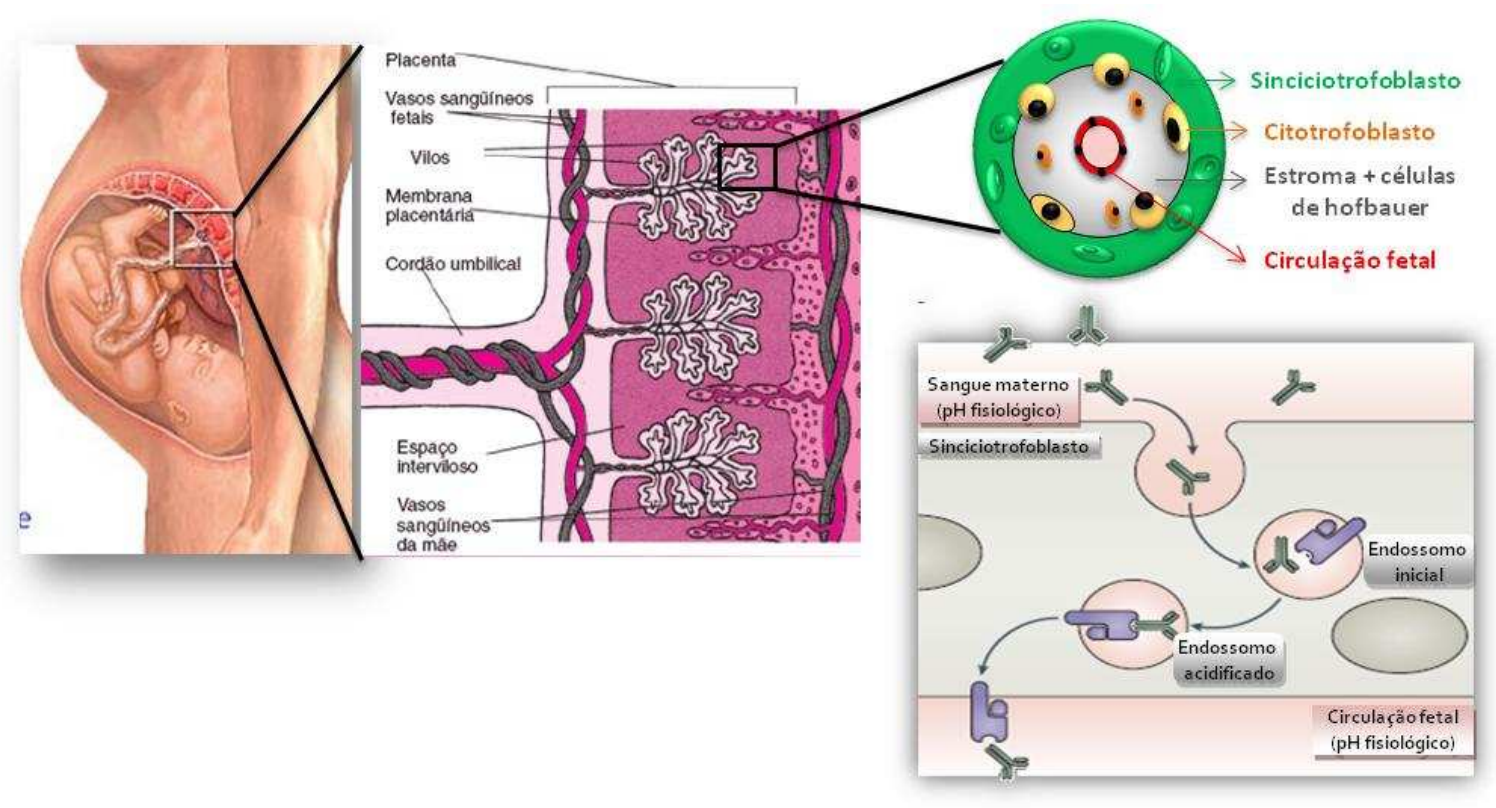

Nos humanos, a passagem transplacentária de IgG ocorre através do receptor FcRn localizado no sinciciotrofoblasto da placenta. O sinciciotrofoblasto é banhado por sangue materno e internaliza IgG sérica. O FcRn é expresso na face interna da vesícula do sinciciotrofoblasto. Com a acidificação dos endossomos, o FcRn se liga a IgG materna e a transição à circulação fetal se dá em pH fisiológico.

FONTE: Adaptado de Roopenian et al., 2007.

Outras variáveis também influenciam na taxa de passagem transplacentária de anticorpos. Como citado anteriormente, a prematuridade é uma delas: baixos níveis de anticorpos são observados ao nascimento enquanto que para recémnascidos a termo os níveis de IgG no cordão umbilical costumam exceder os níveis maternos (Palmeira et al., 2012). Também já foi demonstrado que a hipergamaglobulinemia materna está associada com redução na taxa de passagem 
transplacentária (Gendrel et al., 1990). Essa observação está de acordo com a hipótese de Brambell e pode ser explicada pela saturação dos receptores FcRNs na presença de altas concentrações de anticorpos (Brambell et al., 1949).

Assim, a concentração de IgG materna no cordão umbilical depende da concentração de anticorpos maternos, da quantidade de receptores expressos pela mãe e da taxa de ligação e de liberação de moléculas de lgG por esses receptores (Moraes-Pinto et al., 2001).

\section{d) Anticorpos lgG e subclasses}

Os humanos apresentam quatro subclasses de $\lg G$ (lgG1, $\lg G 2$, $\lg G 3$ e $\lg G 4$ ) e a diferença entre elas está na cadeia pesada. Apesar de compartilharem 95\% de homologia, esta pequena diferença estrutural é suficiente para apresentarem diferenças funcionais significativas, resumidas na tabela 2.

Tanto a IgG1 como a lgG3 estão envolvidas nas respostas contra antígenos proteicos e funcionam como boas moléculas de opsonização. A lgG1 é a subclasse de maior concentração sérica e a lgG3 é a subclasse com maior potencial para ativação do complemento e maior afinidade de ligação aos receptores Fc de fagócitos.

Já a lgG2 é produzida em resposta a polissacarídeos como os presentes na superfície de pneumococos e, portanto, está envolvida nas respostas Tindependentes.

A lgG4 é a subclasse encontrada em menor concentração no soro e diferente das outras subclasses não ativa o sistema complemento. Sua produção ocorre após estímulo antigênico prolongado e repetitivo. Assim como para lgE, o swith de classe da lgG4 é influenciado pela IL-4 e IL-13 e sua produção é aumentada na presença de IL-10, IL-12 e IL-21 (Sigal, 2012). A IgG4 apresenta ainda algumas características estruturais peculiares à ela: As ligações entre as duas cadeias pesadas não são estáveis como para as outras subclasses. Isso permite que ocorram rearranjos entre as cadeias leves e pesadas a tornando uma imunoglobulina assimétrica, onde cada região Fab apresenta uma especificidade diferente. Apesar desta capacidade, na maioria das vezes comportam-se como anticorpos monovalentes (Aalberse et al., 2009). A consequência desta característica única à IgG4 ainda é desconhecida, mas evidências sugerem que 
possa estar relacionada com a regulação da resposta imunológica (Frew et al., 2010; Ruiter et al., 2007). Faz sentido se lembrarmos de que ela é produzida após estimulo antigênico repetitivo e induzida por citocinas liberadas por células $T$ regulatórias, como a IL-10.

\section{Tabela 2 - Subclasses das IgGs: Concentração e características}

\begin{tabular}{|c|c|c|c|c|c|}
\hline & $\begin{array}{c}\text { Concentração } \\
\text { sérica em } \\
\text { adulto (g/L) }\end{array}$ & $\begin{array}{l}\text { Porcentagem } \\
\text { de IgG sérica }\end{array}$ & $\begin{array}{l}\text { Ativador do } \\
\text { sistema } \\
\text { complemento }\end{array}$ & $\begin{array}{l}\text { Afinidade aos } \\
\text { receptores Fc } \\
\text { nos fagócitos }\end{array}$ & $\begin{array}{l}\text { Meia } \\
\text { vida } \\
\text { (dias) }\end{array}$ \\
\hline $\lg G 1$ & $4.9-11.4$ & 66 & Segundo maior & Alta & 21 \\
\hline $\lg G 2$ & $1.5-6.4$ & 23 & Terceiro maior & Muito baixa & 21 \\
\hline $\lg G 3$ & $0.2-1.10$ & 7 & Maior & Alta & 7 \\
\hline $\lg G 4$ & $0.08-1.4$ & 4 & Não ativa & Intermediária & 21 \\
\hline
\end{tabular}

Fonte: Modificado de Sigal, Clin Rheumatol 2012;18: 316-318

e) Influência de anticorpos maternos para alergia da criança

Os anticorpos lgG de origem materna são detectados no recém-nascido na concentração média de 1000 mg/dL. Estes níveis caem durante os três primeiros meses de vida, ao passo que a síntese de lgG própria aumenta gradativamente.

Além da proteção passiva que os anticorpos maternos fornecem, eles também podem ativar e modular o sistema imunológico da criança. Estudos mostram claramente que anticorpos alérgenos-específicos são transferidos via passagem transplacentária e modulam a resposta alérgica na criança (Jenmalm et al., 2000; Platts-Mills et al., 2003; Prescott et al., 2000).

Essa forte influência materna começou a ser melhor compreendida através dos estudos de Jarrett e colaboradores (1983) que chamaram a atenção sobre o possível papel da IgG materna em suprimir a produção de $\lg E$ específica e consequentemente inibir a resposta alérgica na criança. Embora os mecanismos pelos quais a $\operatorname{lgG}$ materna possa suprimir a produção de lgE pelo recém-nascido ainda não esteja bem estabelecido, os mecanismos propostos incluem: a) A ligação da IgG ao alérgeno esconde seus determinantes antigênicos e permite sua eliminação através da fagocitose por macrófagos b) a ligação da IgG bloqueia a ligação da $\lg E$ ao alérgeno e, consequentemente, inibe a degranulação de mastócitos e c) a ligação de imunecomplexos a receptores inibitórios FcyRllb nos linfócitos $B$ ou células dendríticas do neonato inibe a síntese de $\lg E$ específica (Boyle et al., 2006; Strait et al., 2006). Todos mecanismos são influenciados pela 
dose, freqüência e forma de exposição ao antígeno; além das características genéticas da mãe e criança (Jarrett, 1984).

Posteriores estudos em modelos animais confirmaram que a inibição conferida pela IgG materna é antígeno específica e dependente da concentração de anticorpos (Melkild et al., 2002; Polt et al., 2008; Seenger et al., 1998; Uthoff et al., 2003; Victor et al., 2003). Entretanto, ainda não está claro qual o mecanismo de ação da lgG materna responsável por essa inibição.

Estudos epidemiológicos em humanos indicam que a passagem de IgG alérgeno específica via placenta também pode ter efeito protetor. Altos níveis de lgG materna específica tanto a alérgenos alimentares como ambientais no cordão umbilical mostrou estar associada a menor prevalência de alergia ao mesmo alérgeno nas crianças (Dannaeus et al., 1978; Jenmalm et al., 2000; Nafstad et al., 2001).

Muitos pesquisadores atribuem papel protetor à subclasse lgG4, pois como explicado anteriormente consegue neutralizar o antígeno induzindo menor resposta inflamatória quando comparada às outras subclasses (Aalberse et al., 1993; Gondo et al., 1987; Mori et al., 2001). Além disso, esta subclasse está envolvida no padrão de resposta imunológica estabelecido nas imunoterapias alérgeno-específicas, onde observamos aumento nos níveis de IgG4 e queda na concentração de IgE específica (Frew, 2007).

O fato de que nem todas as crianças apresentem correlação positiva entre os níveis de IgG no cordão umbilical e proteção a alergia sugere que a "falha" no efeito protetor da lgG pode estar relacionada com a inabilidade que alguns recém-nascidos têm em responder ao mecanismo regulatório (Prescott et al., 2000).

Um dos principais determinantes para o risco à sensibilização na infância parece ser o estado de maturação do sistema imune em relação ao balanço $T_{H} 1 / T_{H} 2$ no momento em que entra em contato com o alérgeno (Holt et al., 2005). A função $\mathrm{T}_{\mathrm{H}} 1$ com capacidade de produzir IFN- $\gamma$ tende a aumentar progressivamente durante a infância, mas alguns grupos observaram que recém-nascidos com alto risco em desenvolver alergia apresentam lenta polarização para atividade $T_{H} 1$ com deficiência na resposta ao IFN- $\gamma$, quando comparados aos neonatos de baixo risco (Kondo et al., 1992). Crianças de alto risco também manifestam deficiência na resistência a infecções e resposta a vacinas, aparentemente relacionada com atenuada função $\mathrm{T}_{\mathrm{H}}$ 1 (Fallon et al., 2007). 
De acordo com essas observações, o grupo da pesquisadora Tulic mostrou recentemente que crianças não alérgicas apresentam resposta do sistema imunológico inato (caracterizada pela secreção de IL-1 $\beta$, IL-6, TNF- $\alpha$, e IL-10 após estimulo a virtualmente todos os ligantes de Toll) baixa ao nascimento, mas com aumento progressivo ao passar dos anos. Além disso, este aumento está correlacionado com a maturação da resposta adaptativa de perfil Th1 (IFN-ү) após estímulo com alérgenos. Por outro lado, crianças alérgicas apresentam resposta imune inata exagerada ao nascimento e relativo declínio com o passar dos anos. Ainda, crianças alérgicas apresentam aumento dependente da idade para resposta Th2 alérgeno-específica e baixa resposta de perfil Th1 aos cinco anos de idade (Tulic et al., 2011).

Esses dados sugerem que a trajetória de desenvolvimento do sistema imune inato é diferente entre as crianças alérgica e não alérgicas. Essas diferenças podem influenciar o padrão de resposta imune adaptativa que a criança irá desenvolver após reconhecimento do alérgico no período pós natal.

\subsubsection{Período pós-natal}

Uma vez cortado o cordão umbilical, os imunologistas muitas vezes analisam o recém-nascido como uma entidade que se desenvolve por conta própria; sem levar em consideração a interação mãe-filho que o aleitamento materno proporciona e contribui a este processo.

O leite materno é um fluido corporal complexo e sua composição é única para cada mãe e dinâmica durante o período de amamentação. Isto significa que a composição do leite varia consideravelmente não apenas entre as mães, mas também na mesma mãe, hora pós hora e dia pós dia, adaptando-se às necessidades do desenvolvimento da criança (Lawrence, Camille, 2007). Um exemplo é a composição do colostro em relação ao leite maduro. Em média, o colostro apresenta 12g/L de s-IgA, juntamente com S-lgM ( 0.6 g/L) e $\operatorname{lgG}(\sim 0.1 \mathrm{~g} / \mathrm{L})$, mas após duas semanas esta concentração cai aproximadamente 5 vezes e depois se mantêm razoavelmente estável por todo período de lactação (Brandtzaeg, 1983). Outros componentes, como lipídeos, lactose e glucose, variam de concentração no 
decorrer de uma mesma mamada, apresentando variações significativas entre o leite inicial e final (Neville et al., 1984).

Durante anos, o leite materno foi considerado somente uma fonte rica em nutrientes essenciais ao desenvolvimento da criança nos primeiros meses de vida. A frequente observação que a amamentação também proporciona proteção contra doenças infecciosas e reduz a taxa de mortalidade infantil, colocou em evidência a importância que o leite materno tem para o recém-nascido (Quinello et al., 2010).

A propriedade anti-infecciosa do leite materno é devido à presença de componentes antimicrobianos, tais como lactoferrina e lisozima, mas principalmente pela presença de níveis elevados de anticorpos específicos (Lawrence, Camille, 2007).

A glândula mamária integra o sistema imune de mucosa e os anticorpos presentes no leite materno refletem o estimulo antigênico de ambos: GALT (tecido linfoide associado ao trato gastrointestinal) e NALT (tecido linfoide associado à mucosa nasal). Durante o período de lactação, linfócitos $B$ ativados nestes tecidos migram para a glândula mamária e nela diferenciam-se em células secretoras de anticorpos, principalmente IgA e IgM. (Brandtzaeg, 1983; Hanson, 2007). Assim, a IgA presente no leite é específica aos antígenos intestinais e respiratórios aos quais a mãe foi exposta. Outras imunoglobulinas como a $\lg G$ e $\lg D$ também estão presentes no colostro, mas não se sabe se são secretadas localmente ou provenientes do soro (Brandtzaeg, 2009).

A IgA é um anticorpo não inflamatório que inibe a colonização microbiana. Ela diminui a aderência de vírus e bactérias na superfície da mucosa e protege 0 lactente contra infecções intestinais e respiratórias, como ao vírus sincicial respiratório (Brandtzaeg, 2003). A IgA pode ainda capturar antígenos que serão eliminados através do próprio peristaltismo intestinal; função conhecida como exclusão imune (Brandtzaeg, 2002). Além da proteção sem indução de resposta inflamatória, a IgA também pode exercer efeitos imunorregulatórios (Favre et al., 2005; Pilett et al., 2004; Sletten et al., 2007; Smiths et al., 2009). Evidências epidemiológicas de que a IgA previne a manifestação de doenças alérgicas pode ser explicada por estes dois mecanismos, ou seja, por seu efeito imunorregulatório e anti-inflamatório (Calbi et al., 1998; Janzi et al., 2009; Savilahti et al.,1991, 2005).

A proteção à alergia conferida pelo leite materno pode estar relacionada, além da presença de anticorpos, à presença de inúmeros alérgenos, que estão ausentes 
nos leites artificiais, associando a sua apresentação ao recém-nascido em ambiente tolerogênico (Macchiaverni et al., 2012).

\section{a) Antígenos alimentares}

Além de proteínas endógenas, o leite materno contém proteínas exógenas derivadas da dieta materna. Os alérgenos alimentares já detectados no leite materno incluem a beta-lactoglobulina do leite de vaca, a ovalbumina e ovomucoide da clara do ovo, os alérgenos Ara $h 1$ e Ara $h 2$ do amendoim e gliadina presente no glúten (Axelsson et al.,1986; Bertino et al.,1996; Cant et al.,1985; Cavagni et al.,1988; Chirdo et al.,1998; Fukushima et al.,1997; Hirose et al., 2001; Host et al.,1988,1990; Jakobsson et al., 1985; Kilshaw et al.,1984; Kilshaw et al.,1984; Lovegrove et al.,1996; Machtinger et al.,1986; Palmer et al., 2005; Sorva et al.,1994; Stuart et al., 1984; Troncone et al.,1987; Vadas et al., 2001; Vance et al., 2005).

Para todos os alérgenos acima citados, a concentração detectada no leite materno varia muito de mãe para mãe. Mesmo após a ingestão da mesma quantidade de proteína apenas 50-70\% das mulheres apresentam níveis detectáveis no leite e o pico de concentração pode aparecer após algumas horas ou dias, dependendo da mãe.

\section{b) Antígenos respiratórios}

Já foi demonstrado em modelo animal que antígenos inalados pela mãe também podem ser encontrados no leite em concentrações similares às descritas para os antígenos alimentares. A ovalbumina administrada via aerosol no período de lactação foi encontrada no leite materno na forma livre em camundongos naïves e em imunecomplexos $\lg$ ou $\lg A$ em camundongos sensibilizados ao mesmo alérgeno. (Mosconi et al., 2010; Verhasselt et al., 2008).

Ainda que seja surpreendente quando considerado pela primeira vez, a presença de antígenos inalados pela mãe no leite materno pode ser explicada uma vez que a $95 \%$ deles ficam aprisionados no muco nasal e são encaminhados ao trato digestivo através dos movimentos ciliares (Holt et al., 1981; Willoughby et al., 1977). Os antígenos presentes na mucosa intestinal são então absorvidos e encaminhados à circulação sanguínea (Denis, 2012). No caso dos antígenos 
inalados, uma pequena porção pode ainda alcançar a circulação pela absorção direta na barreira capilar alveolar do pulmão (Bensch et al.,1967; Braley et al.,1978).

No entanto, em humanos ainda não há nada descrito sobre a presença de alérgenos ambientais no colostro e/ou leite materno.

\section{c) Fatores que determinam a presença de alérgenos no leite materno}

A concentração de alérgenos alimentares no leite materno apresenta grande variação inter-individual, e pouco ou nada se sabe sobre os fatores que determinam sua concentração. Estes fatores provavelmente incluem a composição da dieta materna, a digestão e transferência do antígeno pela barreira intestinal, o "clearance" do antigeno na circulação sanguínea e a transferência do antígeno da glândula mamária para o leite (Macchiaverni et al., 2012).

Embora ainda exista alguma controvérsia, grande parte dos estudos indica que a quantidade de proteína ingerida pela mãe influencia, mas não determina a presença e/ou concentração do antígeno alimentar no leite materno (Axelsson et al., 1986; Denis, 2012; Fukushima et al., 1997; Palmer et al., 2006, 2008; Vance et al., 2005). O estado atópico da mãe também parece não estar associado com maior ou menor concentração de antígeno no leite (Host et al.,1988; Vance et al.,2005).

Como ainda não há relatos sobre a presença e concentração de antígenos respiratórios no colostro e leite materno, nada se sabe sobre sua relação com a exposição materna.

d) Evidências de que a presença de alérgeno no leite materno pode prevenir a alergia

Em alguns casos a alergia ao leite de vaca pode se manifestar em lactentes durante o período de amamentação exclusiva, indicando que os alérgenos transferidos via leite podem sensibilizar e desencadear alergia na criança. Nestes casos o tratamento recomendado tem sido restrição na dieta materna (Host, 1999). Embora este também seja o tratamento clássico para prevenção de alergia em adultos, a exclusão de alérgenos alimentares como forma primária de profilaxia mostram resultados controversos, com alguns apontando indiferença ou ainda 
aumento na sensibilização (Corver et al., 2006; Terreehorst et al., 2003; Woodcock et al., 2003).

De acordo com as informações expostas anteriormente, sabemos que não há correlação direta entre a ingestão materna de antígenos alimentares e sua concentração no leite. Por isso a restrição alimentar não assegura que a concentração de antígeno no leite será mais baixa e tão pouco se esta irá contribuir para proteção ou exacerbação da alergia na criança. Por outro lado, estudos em modelo animal mostram claramente que a transferência de antígeno via leite materno pode prevenir de maneira específica a manifestação alérgica (Auerbach et al.,1975; Komatsu et al.,1988; Korotkova et al., 2004; Mosconi et al., 2010; Strobel et al., 1984; Telemo et al.,1987; Verhasselt et al., 2008).

Mas qual seria a vantagem para a criança de entrar em contato com o antígeno via leite materno, comparada à exposição direta ao antígeno logo no inicio da vida? Enquanto que as proteínas endógenas do leite materno são encontradas na faixa de $\mathrm{mg} / \mathrm{mL}$, os antígenos alimentares são detectados em níveis muito mais baixos, em torno de $\mathrm{ng} / \mathrm{mL}$. Ou seja, enquanto uma criança amamentada por leite formulado recebe exclusivamente grandes concentrações (g/dia) de antígenos de leite de vaca, a criança amamentada recebe diariamente, do nascimento até o desmame, pequenas quantidades (ng/dia) de diversos antígenos ingeridos pela mãe. Já foi demonstrado que baixas concentrações de alérgenos continuamente apresentados via mucosa intestinal são de fato necessários para indução da tolerância oral (Faria, Weiner, 2005). Assim, a amamentação pode funcionar como fonte contínua de alérgenos que são transferidos juntamente com outros fatores imunológicos necessários para indução de tolerância oral na criança.

A importância da transferência de alérgenos ambientais via aleitamento materno foi recentemente demonstrada em modelo animal: Camundongos amamentados por mães expostas via aerosol ao alérgeno (OVA) durante o período de lactação foram protegidos contra asma pela indução de tolerância oral. A presença do antígeno juntamente com TGF- $\beta$ no leite materno foi responsável pela proteção observada. Ao investigarem se o mesmo efeito era verdadeiro em mães sensibilizadas (caracterizada pela presença de lgG alérgeno-específica) verificaram que a proteção era ainda mais forte e duradoura que a observada anteriormente (Mosconi et al., 2010). 
Ou seja, a tolerância oral ocorre se no leite materno estiver presente o alérgeno, acompanhado de cofatores que favoreçam a indução de tolerância: TGF- $\beta$ e/ou anticorpos maternos IgG alérgenos-específicos (Mosconi et al., 2010; Verhasselt et al., 2008). A figura 4 exemplifica este mecanismo.

\section{Figura 4- Tolerância mediada pela transferência de antígenos via leite materno.}

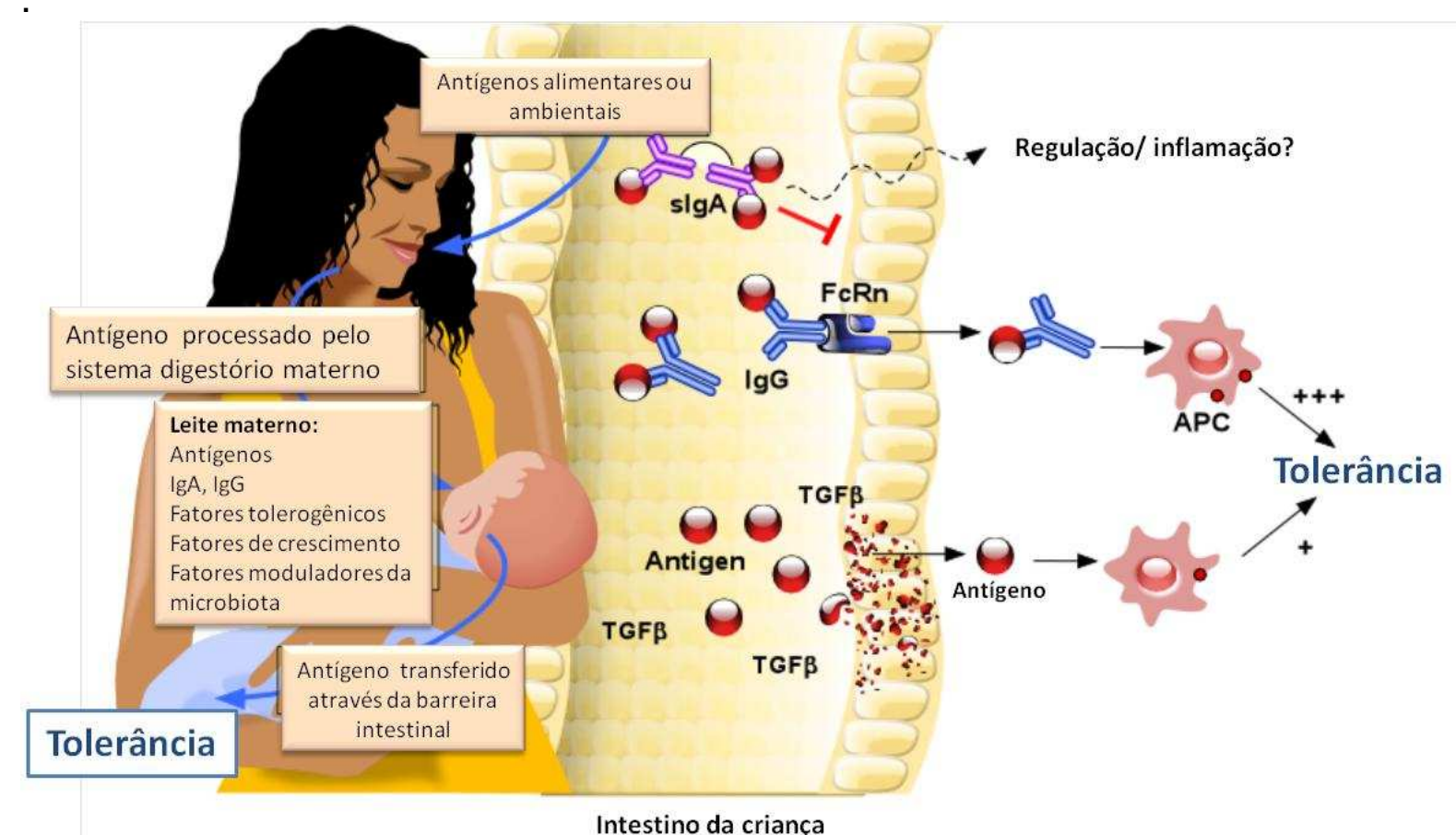

A sensibilização materna ao alérgeno inalado irá determinar se o antígeno será encontrado no leite materno na forma livre ou em imunecomplexos com lgG ou $\lg A$. Nas mães sensibilizadas, o antígeno é encontrado na forma de imunecomplexos ligado a $\lg G$ e pode ser transferido através da mucosa intestinal via receptor FcRN. Nas mães não sensibilizadas, o antígeno é encontrado na forma livre e também pode ser transferido, no entanto de maneira menos eficiente. Após sua transferência o antígeno será provavelmente capturado pelas células apresentadoras de antígeno do recém-nascido, que induzirá a geração de células $T$ reguladoras. A presença de TGF-beta é um cofator necessário para a indução de tolerância quando o antígeno não está ligado a IgG materna. A presença da $\lg A$ é importante para eliminar o antígeno na mucosa intestinal e impedir sua transferência ao recém-nascido, mas em modelo animal não mostrou apresentar importante papel regulatório.

Fonte: Modificado de Verhasselt, 2010.

O TGF-beta é um fator de crescimento que promove a tolerância mediada por linfócitos $\mathrm{T}$ e ajuda a inibir a resposta inflamatória e a manter a homeostase no intestino (Penttila 2003, 2006). Em humanos, a concentração de TGF- $\beta$ no leite mostrou estar inversamente correlacionado com o risco de alergia na criança e em 
modelo animal foi necessária para indução de tolerância oral (Kalliomaki et al., 1999; Oddy et al., 2003). Já o efeito benéfico do anticorpo materno na indução de tolerância oral está relacionado ao melhor transporte do alérgeno através da mucosa digestiva via receptor FcRN, uma vez que este pode apresentar-se complexado aos anticorpos.

\section{Figura 5- Possível influência materna na indução de tolerância no recém- nascido.}

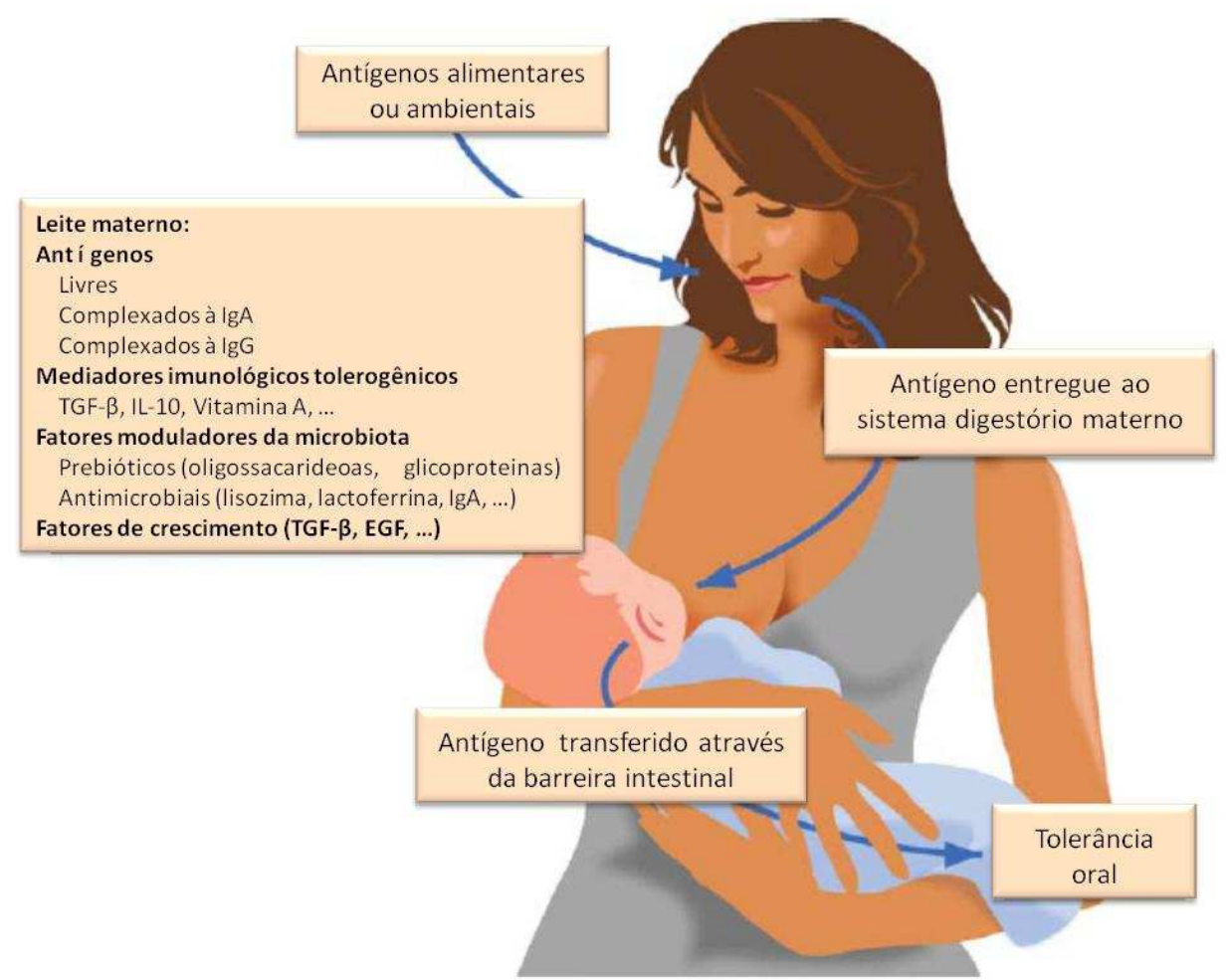

Antes de alcançar o leite, antígenos alimentares e ambientais serão capturados pela mucosa digestiva materna podendo contribuir para geração de peptídeos tolerogênicos. Dependendo da exposição materna e permeabilidade da glândula mamária, grande parte dos antígenos será encontrada no leite. A sensibilização materna ao antígeno irá determinar se este será encontrado na forma livre ou em imunecomplexos IgG ou lgA. A presença de IgA irá eliminar o antígeno e impedir que este seja transferido à criança, enquanto que o antígeno ligado a IgG irá ser transferido de maneira eficiente através da barreira epitelial por meio do FcRn. A maturação do epitélio intestinal será acelerada pela presença de fatores de crescimento no leite materno, como TGF e EGF. A presença de fatores imunomoduladores no leite como o TGF-beta, irá favorecer a indução de tolerância ao antígeno transferido. Finalmente, probióticos presentes no leite materno como oligossacarídeos, irão estimular o desenvolvimento da microbiota promovendo a indução de tolerância imunológica.

Fonte: Modificado de Verhasselt, 2010. 
Em resumo, o leite materno pode proteger a criança contra alergia por transferir o alérgeno de forma continua, juntamente a outros componentes que funcionam como co-fatores na indução de tolerância. Assim, o potencial tolerogênico do leite materno depende do perfil de resposta imune da mãe, da maneira pela qual ocorreu a exposição e processamento do antígeno, da permeabilidade da glândula mamária e por fim, da presença e concentração de antígenos juntamente a fatores que influenciam a indução de tolerância (Verhasselt, 2010). (Figura 5)

\subsection{Justificativa}

Vimos que estudos em modelo animal mostram que a transferência de antígenos e anticorpos maternos no período de gestação e amamentação tem o potencial de proteger a prole contra manifestação alérgica. No entanto, estudos em humanos ainda são escassos e os resultados controversos. Acreditamos que os dados obtidos em modelo animal nos fornece uma forte base científica para investigarmos em humanos a presença de antígenos ambientais e seus anticorpos no cordão umbilical e leite materno. Até o momento, a presença dos alérgenos Der $p$ 1 e Blo $t 5$ assim como seus anticorpos específicos no colostro não foi descrita e tão pouco levada em consideração como possível fator profilático para alergia na criança. $\mathrm{O}$ trabalho que será exposto representa o primeiro passo para que os dados obtidos em modelo animal possam ser transferidos aos humanos. Estudos clínicos posteriores serão necessários para verificar em quais condições esta transferência pode conferir proteção ou favorecer a sensibilização na criança 
2 OBJETIVOS 


\section{Objetivo geral}

Verificar em humanos a transferência passiva de alérgenos ambientais e seus anticorpos específicos via passagem transplacentária e aleitamento materno.

\section{Objetivos específicos}

- Quantificar os alérgenos ambientais (Der p 1 e Blot 5) em amostras de colostro e sangue de cordão umbilical;

- quantificar a lgA e lgG alérgeno-específica no colostro;

- quantificar a lgG alérgeno-específica e suas subclasses no cordão umbilical e na mãe;

- comparar e relacionar as concentrações encontradas com o estado atópico materno. 
3 CASUISTICA E MÉTODOS 


\section{Seleção da casuística}

A população avaliada foi constituída de 91 puérperas e seus respectivos recém-nascidos, atendidos na Maternidade de Campinas no período de fevereiro a julho de 2006 e de janeiro a maio de 2009.

Estabelecemos como critérios de inclusão a idade gestacional (de 37 semanas completas a 39 e 6/7 semanas), ausência de doenças sistêmicas (como diabetes e hipertensão), infecções e imunodeficiência, uso de transfusão sanguínea, anti-histamínicos, corticoides ou outra droga relacionada a doenças sistêmicas durante a gestação. Também foram excluídas as mães de recém-nascidos pré-termo ou com baixo peso para a idade gestacional. Não houve restrições ao grupo étnico, idade, escolaridade, paridade, história de aleitamento anterior, ou tipo de parto. Obtivermos estes dados na ficha de internação.

Para verificar a influência da sensibilização materna nos níveis de antígenos e anticorpos selecionamos algumas amostras e as dividimos em dois grupos de acordo com estado atópico materno: (1) grupo de mães atópicas, definido por níveis de anticorpos lgE específicos $>3,5 \mathrm{KU} / \mathrm{L}$ associado a sintomas clínicos de alergia e (2) grupo de mães saudáveis não atópicas, definido por níveis de anticorpos lgE específicos $<0,35 \mathrm{KU} / \mathrm{L}$ e ausência de sintomas clínicos de alergia. Os dados das mães que não se enquadraram nestas características foram utilizados nas análises que não tinham como objetivo avaliar a influência do estado atópico materno.

O diagnóstico de alergia respiratória foi estabelecido após caracterização de uma história clínica compatível e exames laboratoriais. Obtivemos o histórico clinico por meio de questionário simples aplicado às puérperas para levantamento dos antecedentes de doença alérgica pessoais. Os exames laboratoriais incluíram a quantificação de níveis séricos de $\lg \mathrm{E}$ específica anti-Der $p$ e anti-Blo $t$. Níveis séricos acima de $3.5 \mathrm{KU} / \mathrm{L}$ (classe $\geq 3$ ) são considerados positivos e abaixo de $0.3 \mathrm{KU} / \mathrm{L}$ (classe 0 ) negativos. 


\subsection{Obtenção das amostras}

\section{a) Coleta:}

Após assinatura do termo de consentimento livre e esclarecido coletamos de cada mãe voluntária uma amostra de sangue venoso, uma amostra de colostro e uma amostra de sangue do cordão umbilical. No caso de menores de 21 anos de idade, o responsável legal pela voluntária autorizou a inclusão no estudo, assinando temo de consentimento.

- Sangue de cordão umbilical: A pesquisadora ou o obstetra responsável coletaram aproximadamente $50 \mathrm{~mL}$ de sangue em tubo seco, logo após sua ligadura ou após dequitação da placenta. O sangue foi coletado, com auxílio de agulha e seringa descartáveis para evitar a contaminação com sangue materno. Além disso, antes da coleta o local da pulsão foi limpo e esterilizados.

- Colostro: 48 horas após o parto aproximadamente $10 \mathrm{~mL}$ de colostro foram coletados manualmente em tubo seco e sempre no seio oposto da última mamada por enfermeira qualificada e previamente treinada. A amostra permaneceu armazenada a $4^{\circ} \mathrm{C}$ até seu transporte ao laboratório .

- Sangue periférico: 48 horas após o parto (mesmo dia da coleta do colstro) coletamos aproximadamente $30 \mathrm{~mL}$ de sangue materno em tubo seco por meio de punção venosa periférica realizada por enfermeira qualificada tomando-se as devidas precauções de assepsia

\section{b) Processamento do sangue periférico e do cordão umbilical e do colostro:}

No mesmo dia da coleta, as amostras de sangue periférico e de cordão umbilical permaneceram durante duas horas à temperatura ambiente para a coagulação e foram centrifugadas por 15 minutos a $160 \times \mathrm{xG}$. Os soros obtidos permaneceram estocados a $-80^{\circ} \mathrm{C}$ até sua utilizaçã o.

O colostro foi centrifugado por 30 minutos a $160 \times$ G sob refrigeração a $4{ }^{\circ} \mathrm{C}$. Essa centrifugação permite a separação do colostro em três fases nítidas: o "botão" 
celular, uma porção fluida intermediária e uma camada superior de gordura. Desprezamos a camada superior de gordura e o "botão" celular. O sobrenadante (porção fluida) foi aliquotado e estocado a - $80{ }^{\circ} \mathrm{C}$.

\subsection{Quantificação de IgE sérica específica}

A sensibilização materna ao Der p e Blo $t$ foi determinada baseada nos níveis de $\lg E$ específica quantificados pelo equipamento CapSystem®) (Thermo Fisher Scientific, Uppsala, Suécia) popularmente conhecido como "RAST". As dosagens foram realizadas no laboratório de análises clínicas Confiance-Medicina diagnóstica (Campinas-SP) segundo manual do fabricante (Instruções de utilização ImmunoCap Specific IgE Conjugate 100 and 400 - Fluoroenzymeimmunoassay. 52-523799/05:99-112; Johansson, 1988).

\section{Tabela 3 - Classificação das concentrações de lgE específica segundo CapSystem $^{\circledR}$}

\begin{tabular}{l|l|l|l}
\hline Classes & Faixa $(\mathbf{K U} / \mathbf{l})$ & Resultado & Interpretação \\
\hline 0 & $<0,35$ & Indetectável & Negativo \\
1 & $0,35-0,70$ & Fraco & Correlação \\
2 & $0,70-3,50$ & Moderado & Duvidosa \\
3 & $3,50-17,50$ & Forte & Positivo Conclusivo \\
4 & $17,50-50,00$ & Muito forte & Positivo Conclusivo \\
5 & $50,00-100,00$ & Muito forte & Positivo Conclusivo \\
6 & $>100,00$ & Muito forte & Positivo Conclusivo \\
\hline
\end{tabular}

Neste sistema, o extrato do alérgeno é acoplado covalentemente ao ImmunoCAP e reage com a IgE específica da amostra de soro. Após lavagem da $\operatorname{lgE}$ não específica, adiciona-se anticorpo-anti-lgE marcado enzimaticamente para formação dos complexos. Após incubação o anticorpo-anti-lgE não ligado é lavado, procedendo-se à incubação do complexo ligado ao substrato. Após parar a reação, mede-se a presença de IgE específica na amostra.

Para avaliar os resultados, a fluorescência é convertida em concentrações pelo Software do equipamento, utilizando uma curva de calibração. O equipamento realiza todas as etapas do ensaio e tem amplitude de 0,35 - 100kU/l, onde resultados abaixo de $0,35 \mathrm{kU} / \mathrm{l}$ representam ausência ou níveis indetectáveis de anticorpos alérgeno-específicos. 
Conforme exemplificado na tabela 3, os resultados em $\mathrm{kU} / \mathrm{L}$ são classificados quanto à reatividade em classes de 0 a 6 e considerado positivo quando $\geq 3$.

\subsection{Quantificação de IgE sérica total}

Os níveis séricos de lgE total materna foram avaliados pelo sistema ADVIA Centaur® (Siemens, Erlangen, Germany) Este teste consiste em um imunoensaio tipo sanduíche de duas etapas utilizando tecnologia quimiolumiométrica direta, que usa quantidades constantes de dois anticorpos contra lgE. O primeiro anticorpo, no reagente Lite, é um anti-lgE humano caprino marcado com éster de acridina e o segundo, na fase sólida, é um anticorpo anti-lgE humano de rato covalentemente ligado a partículas paramagnéticas. A lgE total no soro é expressa em $U \mathrm{Ul} / \mathrm{mL}$ sendo a concentração mínima detectável de 1,5 UI/mL e a máxima de $3.000 \mathrm{UI} / \mathrm{mL}$.

As dosagens foram realizadas no laboratório de análises clínicas ConfianceMedicina diagnóstica (Campinas-SP) e seguiram o Manual do Teste ADVIA Centaur (124666 ver. E, 2003-04: pg 1-10; National Committee for clinical laboratory standards, 1999).

\subsection{Quantificação de lgG sérica total}

Os níveis séricos de IgG total materna e do cordão umbilical foram avaliados por nefelometria, utilizando nefelômetro Behring com padrões e controles apropriados (BN 100 Prospec Berhinger, EUA). As dosagens de imunoglobulinas foram realizadas no laboratório de análises clínicas Confiance-Medicina diagnóstica (Campinas-SP) e seguiram o protocolo de ensaio para nefelômetro (Behringer, EUA). As amostras de soro foram diluídas conforme instruções do fabricante e os resultados expressos em mg/mL. (Dati et al., 1996). 


\subsection{Quantificação de IgA total no colostro}

A IgA total de colostro foi determinada por meio de ensaio imunoenzimatico ELISA. (método modificado de Nagao et al., 2001).

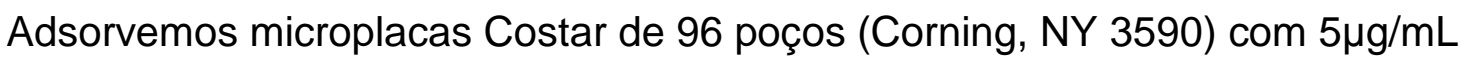
de anti-IgA humana (I-0884, Sigma) em PBS pH7,4 e incubamos overnight em câmara úmida a 4 C. Lavamos 4 vezes com solução PBS - Tween 20 0,1\% e adicionamos as amostras (1:100.000), a curva padrão (3,9 a $250 \mathrm{ng} / \mathrm{ml}$ de $\lg A$ de colostro I-2636, Sigma) e dois controles com concentrações já conhecidas ("pool de colostro"). Após novas lavagens, adicionamos a anti-lgA humana marcada com peroxidase ( $\alpha$-chain specific, Sigma A0295) na diluição de 1:20.000 e incubamos por 1 h 30 min a $37^{\circ} \mathrm{C}$. Diluímos as amostras e anticorpos em tampão PBS NaCL 0,35M-Tween 0,2\%. Utilizamos como substrato $10 \mathrm{mg}$ de ortofenilenodiamina (OPD) dissolvida em $25 \mathrm{~mL}$ de tampão citrato-fosfato $\mathrm{pH} 5.0$ e $10 \mu \mathrm{L}$ de água oxigenada $\left(\mathrm{H}_{2} \mathrm{O}_{2}\right)$. Mantivemos as placas no escuro a temperatura ambiente por $30 \mathrm{~min}$ e adicionamos $50 \mu \mathrm{L}$ de solução "stop" $\left(\mathrm{H}_{2} \mathrm{SO}_{4} 2,5 \mathrm{~N}\right)$. A leitura da placa foi feita em leitor de ELISA em comprimento de onda de $492 \mathrm{~nm}$.

Para o cálculo dos valores de IgA total utilizamos os resultados da leitura em densidade óptica da amostra referência e o programa GraphPad Prism para a construção da curva.

\subsection{Quantificação de anticorpos específicos aos ácaros Dermatophagoides pteronyssinus e Blomia tropicalis}

Em todos os ensaios utilizamos como "coating" o extrato total do ácaro Dermatophagoides pteronyssinus ou Blomia tropicalis, adquiridos na forma liofilizada (Greer Laboratories, Lenoir NC). Ressuspendemos os extratos em água bidestilada e purificada em sistema de filtragem mili-Q e quantificamos a concentração de proteína total através do "BCA Protein Assay Reagent Kit" (Pierce, 23227). A concentração detectada foi de $9,4 \mathrm{mg} / \mathrm{mL}$ e $11,22 \mathrm{mg} / \mathrm{mL}$, respectivamente. Os mantivemos aliquotados e estocados a $-80^{\circ} \mathrm{C}$.

Como não existe comercialmente um soro ou sobrenadante de colostro com concentração conhecida de anticorpos específicos ao Der $p$ ou Blo $t$, houve a necessidade de se utilizar um pool como amostra referência para construção da 
curva padrão. Um pool de soro e outro de colostro foi elaborado com amostras coletadas de 24 mães que apresentaram histórico de alergia respiratória relacionada à poeira domiciliar e lgE específica classe $\geq 4$. Assim, o resultado foi expresso em unidades arbitrarias (UA/mL), através da comparação dos valores de densidade óptica (OD) do pool, ao qual se atribuiu o valor arbitrário de 1.000 unidades por mililitro (1.000 UA/ml). De maneira semelhante, outros dois pools serviram como controles dos ensaios: pool amostras com IgE específica classe $=3(n=6)$ e pool amostras com lgE específica classe $=0(n=5)$.

Em todos os ensaios dois poços "brancos" foram empregados para avaliar a ligação inespecífica entre o anticorpo conjugado e as proteínas do extrato. O valor da densidade óptica dos poços "brancos" de cada placa foi sempre subtraído da densidade óptica das amostras, referências e controles.

\section{Detalhamento da técnica}

Adsorvemos microplacas (Costar, Cambridge, MA, USA) overnight a $4{ }^{\circ} \mathrm{C}$ com $5 \mu \mathrm{g} / \mathrm{mL}$ de extrato total de Der $p$ ou Blot diluídos em PBS $\mathrm{pH} 7,4$. As placas foram então saturadas com solução Molico ${ }^{\circledR}$ (leite de vaca em pó desnatado) $5 \%$ em PBS Tween 20 0,1\% por uma hora, em câmara úmida, a $37^{\circ} \mathrm{C}$.

As amostras e anticorpos secundários foram adicionados conforme descrito na tabela 4. Testamos todas as amostras em duplicatas e em quatro diluições seriadas de 1:2. Além disso, amostras pareadas de soro materno e do cordão umbilical foram analisadas na mesma placa. O tempo de incubação para as amostras foi de $2 \mathrm{~h}$, para o anticorpo secundário de $1 \mathrm{~h}$ e 30 min e para enzima (quando necessária) de1h, sempre em câmara úmida a 37 ` $\mathrm{C}$. Após cada etapa, lavamos as placas quatro vezes com PBS-Tween 0,1\% (lavadora de placas Denley, EUA).

Revelamos os anticorpos com solução tampão citrato fosfato $0,1 \mathrm{M}$ pH=5,0 contendo substrato ortofenilenodiamina (OPD, Sigma, EUA) 0,4mg/mL e peróxido de hidrogênio (Merck, Alemanha) a $0,01 \%$ de concentração final. As placas permaneceram incubadas à temperatura ambiente durante 30 minutos protegidas da luz e a reação foi interrompida adicionando-se $50 \mu \mathrm{L}$ de ácido sulfúrico 2,5N.

A leitura colorimétrica foi realizada em leitor de placas de ELISA (Molecular DevicesSpectra Max Plus 384) no comprimento de ondas de 492nm. Para gráficos e cálculos utilizamos o programa GraphPad Prism. 
Tabela 4- Diluições utilizadas no ELISA para quantificação de anticorpos específicos aos ácaros Der p e Blo $t$.

\begin{tabular}{|c|c|c|c|c|}
\hline Anticorpo & "Coating"1 & $\begin{array}{l}\text { Diluição } \\
\text { amostra }^{2}\end{array}$ & $\begin{array}{c}\text { Diluição anticorpo } \\
\text { secundário }\end{array}$ & $\begin{array}{l}\text { Diluição } \\
\text { enzima }^{4}\end{array}$ \\
\hline \multicolumn{5}{|c|}{ Amostras pareadas de soro materno e de cordão umbilical } \\
\hline \multirow{2}{*}{$\lg G$} & $\operatorname{Der} p$ & $1: 200$ & $1: 400^{3 a}$ & - \\
\hline & Blot & $1: 1000$ & $1: 400^{3 a}$ & - \\
\hline \multirow{2}{*}{$\lg \mathrm{G} 1$} & Der $p$ & $1: 5$ & $1: 500^{36}$ & $1: 500^{4 a}$ \\
\hline & Blot & $1: 2$ & $1: 500^{3 b}$ & $1: 500^{4 a}$ \\
\hline \multirow{2}{*}{$\lg G 2$} & Der $p$ & $1: 2$ & $1: 100^{3 c}$ & $1: 1000^{4 a}$ \\
\hline & Blot & $1: 2$ & $1: 500^{3 c}$ & $1: 5004^{a}$ \\
\hline \multirow{2}{*}{$\lg G 3$} & Der $p$ & $1: 4$ & $1: 100^{3 d}$ & $1: 200^{4 a}$ \\
\hline & Blo $t$ & $1: 4$ & $1: 100^{3 d}$ & $1: 200^{4 a}$ \\
\hline \multirow{2}{*}{$\lg G 4$} & Der $p$ & $1: 2$ & $1: 100^{3 e}$ & $1: 500^{4 a}$ \\
\hline & Blot & $1: 2$ & $1: 200^{3 e}$ & $1: 200^{4 b}$ \\
\hline \multicolumn{5}{|c|}{ Soro de cordão umbilical } \\
\hline \multirow{2}{*}{$\lg M$} & $\operatorname{Der} p$ & $1: 4$ & $1: 500^{3 f}$ & $1: 500^{4 a}$ \\
\hline & Blo $t$ & $1: 4$ & $1: 500^{3 f}$ & $1: 500^{4 a}$ \\
\hline \multicolumn{5}{|l|}{ Colostro } \\
\hline \multirow{2}{*}{$\lg G$} & $\operatorname{Der} p$ & $1: 2$ & $1: 500^{3 g}$ & $1: 500^{4 a}$ \\
\hline & Blo $t$ & $1: 2$ & $1: 200^{39}$ & $1: 200^{4 a}$ \\
\hline \multirow{2}{*}{$\lg A$} & Der $p$ & $1: 100$ & $1: 6000^{3 h}$ & - \\
\hline & Blo $t$ & $1: 50$ & $1: 6000^{* 3 h}$ & - \\
\hline
\end{tabular}

(1) Coating: As placas foram adsorvidas com $5 \mu \mathrm{g} / \mathrm{mL}$ de extrato total de Der $p$ ou extrato total de Blo $t$ (ambos da Greer Laboratories; Lenoir, NC). (2) Diluição inicial da amostra. (3a) Anti-lgG humana marcada com peroxidase (A-8419,Sigma); (3b) anti-lgG1 humana biotinilada (555869, BD Pharmingen); (3c) anti-lgG2 humana biotinilada (555874, BD Pharmingen); (3d) anti-IgG3 humana biotinilada (B-3523, Sigma) (3e) anti-lgG4 humana biotinilada (555882, BD Pharmingen); (3f) anti-lgM humana biotinilada (Sigma B1265); (3g) anti-lgG humana biotinilada (555785, BD Pharmingen); (3h) anti-lgA humana marcada com peroxidase (A0295 - Sigma, St. Louis, MO). (4a) Estreptavidina-HRP (554066, BD Pharmingen); (4b) alcalina fosfatase (A-7294, Sigma).

Para a quantificação de IgG4 sérica anti-Blomia, realizamos um método de ELISA amplificado utilizando um kit de amplificação (ELISA amplification System Invitrogen 19.589-019). Resumidamente, adsorvemos as placas com $5 \mu \mathrm{g} / \mathrm{mL}$ do extrato total de Blo $t$ em TBS pH 7,4 e bloqueamos com Molico ${ }^{\circledR} 5 \%$ TBS-Tween. As amostras e anticorpos secundários foram diluídos conforme descrito na tabela 4 no mesmo tampão de bloqueio. Após a incubação com a alcalina fosfatase, lavamos a placa com TBS sem Tween. Reconstituímos o controle positivo, o substrato e amplificador do Kit conforme o manual de instrução. Adicionamos primeiramente 25 uL do controle positivo em 7 diluições seriadas (250ng/mL a 3,9ng/mL) na última fileira da placa (que já estava "reservada" e não recebeu nenhum reagente das 
etapas anteriores). Em seguida adicionamos em todos os poços $50 \mathrm{uL}$ do substrato. Após 15 minutos adicionamos $50 \mathrm{uL}$ do amplificador e incubamos por mais 15 minutos, ambos em temperatura ambiente. A reação foi interrompida adicionandose $50 \mu \mathrm{L}$ de ácido sulfúrico $0,3 \mathrm{M}$ e a leitura colorimétrica realizada em leitor de placas de ELISA (Molecular Devices Spectra Max Plus 384) no comprimento de ondas de $495 \mathrm{~nm}$. Os gráficos e cálculos foram realizados com o software do aparelho.

\subsection{Quantificação dos antígenos Der p 1 e Blo $t 5$}

Quantificamos a presença dos alérgenos Der $p 1$ e Blo $t 5$ em amostras de colostro e cordão umbilical por ELISA utilizando os kits comerciais Der $p 1$ ELISA kit (5H8/4C1) EL-DP1" e "Blo t 5 ELISA kit (4G9/4D9)EL-BT5", ambos da Indoor biotechnologies, com algumas modificações.

Tabela 5- Diluições utilizadas no ELISA para quantificação dos alérgenos Der $p$ 1 e Blo $t 5$.

\begin{tabular}{|c|c|c|c|c|}
\hline Alérgeno & "Coating"1 & $\begin{array}{l}\text { Diluição } \\
\text { amostra }^{2}\end{array}$ & $\begin{array}{c}\text { Diluição anticorpo } \\
\text { secundário }{ }^{3}\end{array}$ & $\begin{array}{l}\text { Diluição } \\
\text { enzima }^{4}\end{array}$ \\
\hline \multicolumn{5}{|c|}{ Soro de cordão umbilical } \\
\hline $\operatorname{Der} p 1$ & anti-Der $p 1^{1 \mathrm{a}}$ & $1: 1$ e $1: 2$ & $1: 1000^{3 a}$ & 1:1000 \\
\hline Blo t 5 & anti-Blo t $5^{1 \mathrm{~b}}$ & $1: 1$ e $1: 2$ & $1: 3000^{3 b}$ & $1: 1000$ \\
\hline \multicolumn{5}{|l|}{ Colostro } \\
\hline $\operatorname{Der} p 1$ & anti-Der $p 1^{1 \mathrm{a}}$ & $1: 1$ e $1: 2$ & $1: 1000^{3 a}$ & $1: 1000$ \\
\hline Blot 5 & anti-Blo t $5^{\text {tb }}$ & $1: 1$ e $1: 2$ & $1: 3000^{36}$ & $1: 1000$ \\
\hline
\end{tabular}

(1) Coating: As placas foram adsorvidas com (a) $2 \mu \mathrm{g} / \mathrm{mL}$ de $\mathrm{mAb} 5 \mathrm{H} 8$ anti-Der $p 1$ ou (b) $50 \mu \mathrm{g}$ de mAb $4 \mathrm{G9}$ anti-Blo $t$ 5; (2) Diluição inicial da amostra; (3) Diluição do anticorpo secundário: (a) mAb 4C1 anti-Der p 1 biotinilado (b) mAb 4D9 anti-Blo t 5 biotinilado. (4) Diluição da enzima: Estreptavidina-HRP (554066, BD Pharmingen).

Resumidamente, placas de 96 poços Maxi-Sorp (Nunc Maxi Sorp 442404) foram adsorvidas com o anticorpo monoclonal anti-Der $p 1$ ou anti-Blo t 5 diluído em tampão carbonato bicarbonato $\mathrm{pH} 9.6$ e incubado overnight a $4{ }^{\circ} \mathrm{C}$. Os poços foram bloqueados com $150 \mu \mathrm{L}$ de BSA 1\% PBS-Tween por $1 \mathrm{~h}$ em temperatura ambiente. Para detecção de Der $p 1$, as amostras e a curva padrão permaneceram overnight a 4 `C. Já no ensaio de detecção de Blo $t 5$ o tempo de incubação foi de $2 \mathrm{~h}$. Adicionamos a curva padrão em sete diluições seriadas de 1:2 na concentração 
inicial de $1 \mathrm{ng} / \mathrm{mL}$ de Der $p 1$ ou $8 \mathrm{ng} / \mathrm{mL}$ de Blo $t 5$. Em seguida, incubamos a placa com o anticorpo monoclonal biotinilado por $2 \mathrm{~h}$ seguido pela estreptavidina-HRP por 30 min, ambos em temperatura ambiente. As diluições das amostras e anticorpos estão descritas na Tabela 5. Utilizamos TMB (50-65-00 - KPL) como substrato e os resultados foram expressos em $\mathrm{pg} / \mathrm{mL}$.

\subsection{Quantificação de TGF-beta no colostro}

Os níveis de TGF-beta foram determinados em amostras de colostro por ELISA, utilizando o kit comercial TGF 1 Emax ${ }^{\circledR}$ ImmunoAssay System (PROMEGA G 7591) de acordo com instruções do fabricante. Resumidamente: Placas Costar de 96 poços (Corning, NY 3590) foram adsorvidas com mAb anti-TGF- $\beta$ Coat diluído 1:1000 em tampão carbonato-bicarbonato, overnight a $4{ }^{\circ} \mathrm{C}$. No dia seguinte, bloqueamos com tampãp TGF ${ }^{\circledR}$ Block $1 \mathrm{X}$, por 35 minutos a $37{ }^{\circ} \mathrm{C}$. Adicionamos as amostras diluídas 1:2 juntamente com a curva padrão diluída 1:1000 e incubamos por $1 \mathrm{~h}$ e $30 \mathrm{~min}$. em temperatura ambiente. Adicionamos o anticorpo secundário Anti- TGF ${ }^{\circledR} 1$ pAb diluído 1:1000 seguido pelo TGF $^{\circledR}$ HRP Conjugate diluído 1:100. Ambos permaneceram incubados por 2 horas em temperatura ambiente. Como substrato, utilizamos TMB e após 15 minutos a reação foi interrompida com adição de acido clorídrico $1 \mathrm{~N}$. A leitura colorimétrica foi realizada em leitor de placas de ELISA (Molecular Device Spectra Max Plus 384) no comprimento de ondas de 450 $\mathrm{nm}$.

\subsection{Análise estatística}

As análises estatísticas foram realisadas com o software GraphPad Prism versão 5.00 para Windows (GraphPad Software, San Diego California USA). Os pontos representam dados individuais e as linhas horizontais a mediana de cada grupo. O teste de Mann-Whitney foi utilizado para determinar diferença estatística quando as amostras não apresentavam distribuição gaussiana, ou seja, não passaram no teste de normalidade D'Agostino-Pearson. Em amostras pareadas foi utilizado o teste Wilcoxon. O teste Kruskall-Wallis foi utilizado para comparar mais de dois grupos, seguido pelo teste Mann-Whitney para determinar em qual grupo encontrava-se a diferença. A relação entre níveis de anticorpos e/ou antígenos foi 
determinado utilizando teste de Spearman. Neste teste a correlação é considerada significante (não nula) quando $p<0,05$ e pode ser negativa (inversamente proporcional) ou positiva (diretamente proporcional). $O$ valor do coeficiente de correlação $(r)$ pode ser baixo caso a relação não seja linear.

Em todos os testes os valores de $p<0,05$ foram considerados estatisticamente significativos e graficamente representados como: $\quad\left({ }^{*}\right) p<0,05 ; \quad\left({ }^{* *}\right) p<0,01$; $\left.{ }^{* * *}\right) p<0,001 ;\left({ }^{* * *}\right) p<0,0001$.

\subsection{Taxa de passagem transplacentária}

Calculamos para cada amostra pareada de soro materno e do recém-nascido a taxa de passagem transplacentária. Ela está representada em porcentagem e corresponde à fração entre a concentração de anticorpos do soro de cordão umbilical a do soro materno. Ou seja:

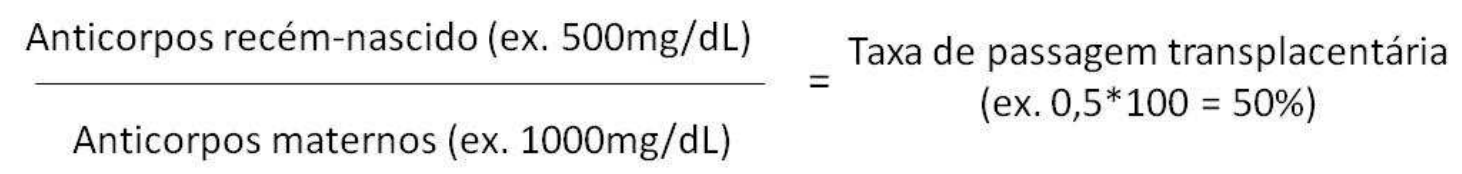




\subsection{Características da população estudada}

A população estudada foi composta por 91 mães distribuídas entre todas as classes sociais e que receberam tratamento hospitalar particular, via convênio médico ou público através do SUS (Sistema Único de Saúde). Todas habitavam moradia de alvenaria com condições básicas de saneamento (água, luz e esgoto), em áreas urbanas da região metropolitana de Campinas. A idade média foi de 26,5 anos, sendo a mais nova com 15 e a mais velha com 40 anos.

Detectamos sensibilização alérgica aos ácaros Der p e Blo $t$ em 30,4 e 15,6\% das mães selecionadas, respectivamente. $9,7 \%$ responderam positivamente para ambos os ácaros (ANEXO A).

Como já foi explicado na metodologia, para verificar a influência da sensibilização materna nos níveis de antígenos e anticorpos a população foi selecionada e dividida em grupos: (1) grupo de mães atópicas e (2) grupo de mães não atópicas. Assim, analisamos separadamente as mães sensibilizadas ao Der $p$ (denominado "grupo Der p") e as mães sensibilizadas ao Blo $t$ (denominado "grupo $B l o t^{\prime}$ ). As características dos grupos encontram-se resumidas na tabela 6.

Constatamos níveis de IgE total extremamente variáveis entre as amostras, com mínimo de 1,5 Ul/mL e máximo de $3910 \mathrm{Ul} / \mathrm{mL}$ (Tabela 6). Como esperado, a concentração sérica materna de $\mathrm{lgE}$ total foi significativamente maior em mães atópicas quando comparadas as não atópicas, tanto para o grupo Der $p$ como para o grupo Blo $t$.

A concentração de $\lg E$ total apresentou correlação com os níveis de $\lg E$ específica em ambos os grupos (Spearman $r=0,6 ; p<0,001$ ).

Outros parâmetros como idade da mãe, peso e comprimento do recémnascido e porcentagem entre meninas e meninos nascidos foram similares entre mães atópicas e não atópicas, em ambos os grupos (Tabela 6). 
Tabela 6- Características da população estudada

\begin{tabular}{|c|c|c|c|c|c|}
\hline \multicolumn{6}{|l|}{ Mãe } \\
\hline & & \multicolumn{2}{|c|}{ Grupo Der $p$} & \multicolumn{2}{|c|}{ Grupo Blo $t$} \\
\hline & & $\begin{array}{l}\text { Atópicas } \\
\qquad(n=28)\end{array}$ & $\begin{array}{c}\text { Não } \\
\text { Atópicas } \\
(n=48)\end{array}$ & $\begin{array}{l}\text { Atópicas } \\
(n=13)\end{array}$ & $\begin{array}{c}\text { Não } \\
\text { atópicas } \\
(n=42)\end{array}$ \\
\hline \multirow{2}{*}{$\begin{array}{l}\text { IgE específica } \\
\text { (KU/L) }\end{array}$} & & $18,45^{* * *}$ & $<0,35$ & $5,76^{* * * *}$ & $<0,35$ \\
\hline & & $(3,4-100)$ & $(<0,35-<0,35)$ & $(3,78-34,3)$ & $(<0,35-<0,35)$ \\
\hline \multirow{2}{*}{$\begin{array}{l}\text { IgE total } \\
\text { (Ul/ml) }\end{array}$} & & $263,2^{* * * *}$ & 16,45 & $264,0^{* * * *}$ & 16,2 \\
\hline & & $(17,3-3910)$ & $(1,5-1543)$ & $(17,3-1487)$ & $(1,5-1543)$ \\
\hline \multirow{2}{*}{$\begin{array}{l}\text { Idade } \\
\text { (anos) }\end{array}$} & & 26,5 & 26,5 & 21 & 27,5 \\
\hline & & $(16-40)$ & $(15-37)$ & $(16-37)$ & $(15-37)$ \\
\hline \multirow{4}{*}{ Gestação (número) } & 1 & $55 \%$ & $35 \%$ & $62 \%$ & $35 \%$ \\
\hline & 2 & $31 \%$ & $38 \%$ & $31 \%$ & $39 \%$ \\
\hline & 3 & $14 \%$ & $17 \%$ & $7 \%$ & $19 \%$ \\
\hline & $\geq 4$ & $0 \%$ & $10 \%$ & $0 \%$ & $7 \%$ \\
\hline \multirow{3}{*}{ Tipo de internação } & Particular & $10 \%$ & $4 \%$ & $0 \%$ & $5 \%$ \\
\hline & Convênio & $73 \%$ & $66 \%$ & $71 \%$ & $66 \%$ \\
\hline & SUS & $5 \%$ & $30 \%$ & $29 \%$ & $29 \%$ \\
\hline \multicolumn{6}{|l|}{ Recém-nascido } \\
\hline \multirow{2}{*}{$\begin{array}{l}\text { Peso } \\
(\mathrm{Kg})\end{array}$} & & 3,2 & 3,3 & 3,2 & 3,4 \\
\hline & & $(2,3-4,2)$ & $(2,4-4,5)$ & $(3,0-4,0)$ & $(2,4-4,5)$ \\
\hline \multirow{2}{*}{ Comprimento $(\mathrm{cm})$} & & 48.6 & 49.1 & 49 & 49 \\
\hline & & $(45-53)$ & $(44.5-52.8)$ & $(46,2-51)$ & $(44,5-52,8)$ \\
\hline \multirow{2}{*}{ Sexo } & Masculino & $52 \%$ & $42 \%$ & $54 \%$ & $41 \%$ \\
\hline & Feminino & $48 \%$ & $58 \%$ & $46 \%$ & $59 \%$ \\
\hline
\end{tabular}

Os valores representam a mediana e entre parênteses o mínimo e o máximo de cada grupo. Os resultados obtidos em mães atópicas e não atópicas foram comparados dentro do mesmo grupo e as diferenças estatísticas calculadas por teste Mann-Whitney. $\left.{ }^{* \star \star \star}\right) p<0,0001$ 


\subsection{Passagem transplacentária de anticorpos alérgenos-específicos}

\section{a) IgG específica ao Der p no cordão umbilical e soro materno}

Verificamos que independente da sensibilização materna a IgG anti-Der $p$ estava presente no cordão umbilical de todos os recém nascidos, mas em concentrações bastante variáveis (tabela 7).

A concentração de IgG anti-Der $p$ foi significativamente maior no cordão umbilical de recém-nascidos de mães atópicas quando comparados a recémnascidos de mães não atópicas (Figura 6a e tabela 7). Assim como seus filhos, mães atópicas apresentaram concentrações de lgG anti-Der $p$ mais elevadas que mães não atópicas (Figura 6a e tabela 7).

Observamos que existe forte correlação entre os níveis de lgG anti-Der $p$ no cordão umbilical e no soro materno, tanto para o grupo de mães atópicas, como para o grupo de mães não atópicas (Figura 6b).

Tabela 7- Concentração de IgG total e anti-Der $p$ no soro materno e de cordão umbilical

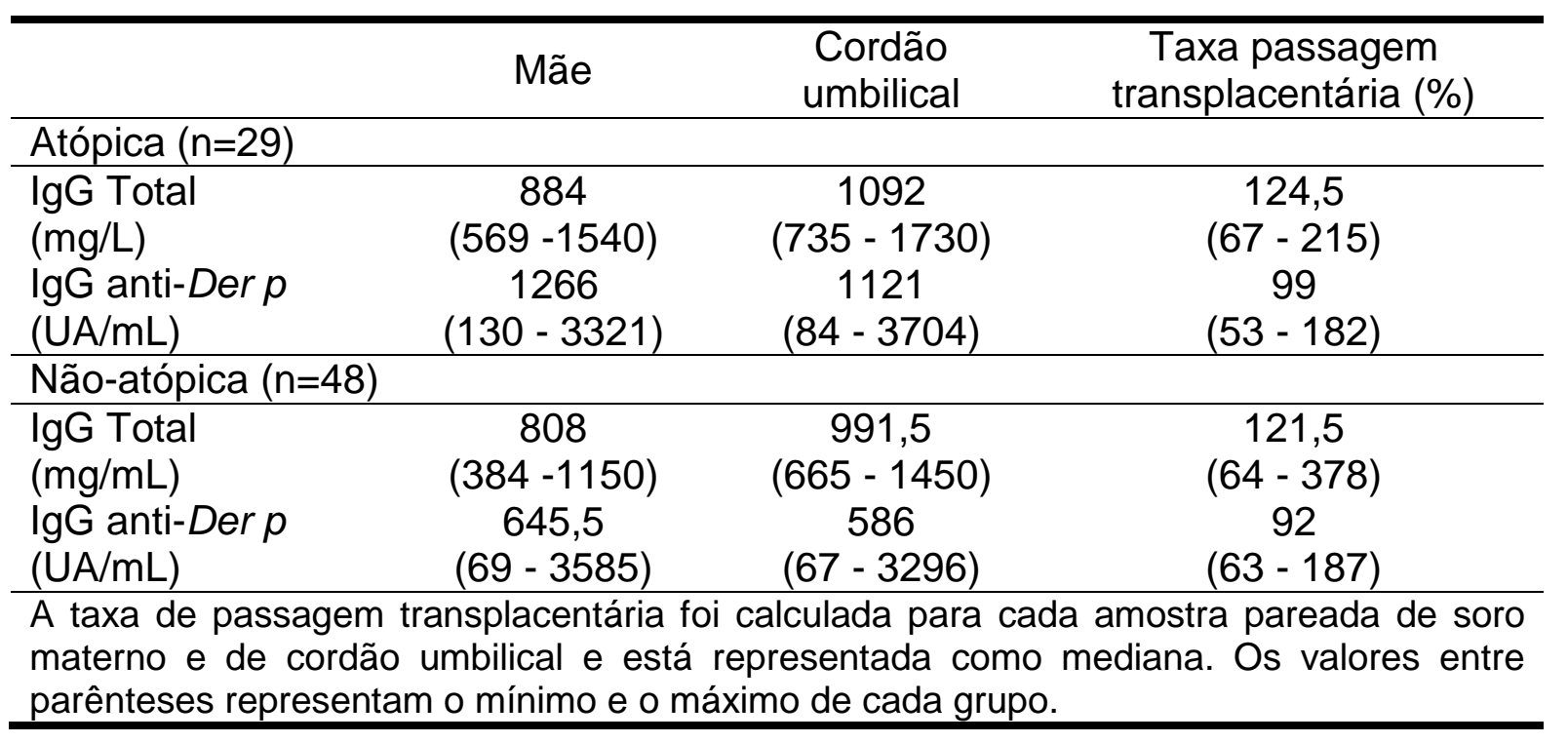


Figura 6- Concentração de IgG anti-Der $p$ no soro materno e no cordão umbilical

(a)

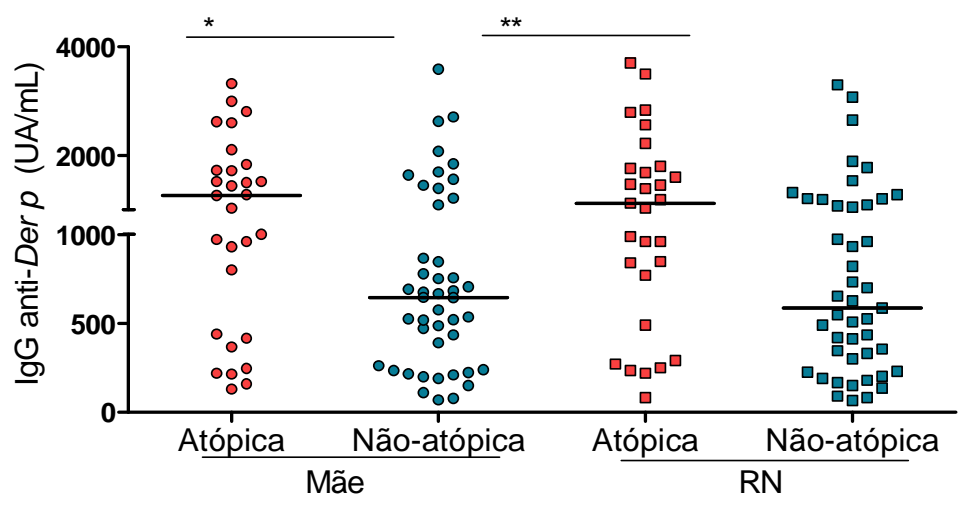

(b) IgG anti-Der $p$

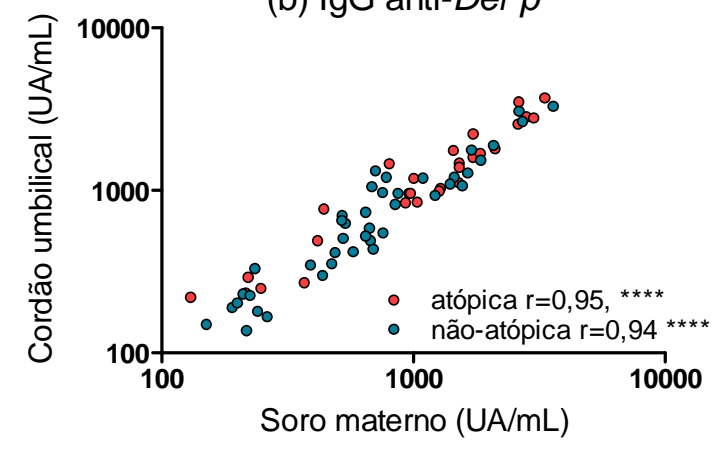

(c)

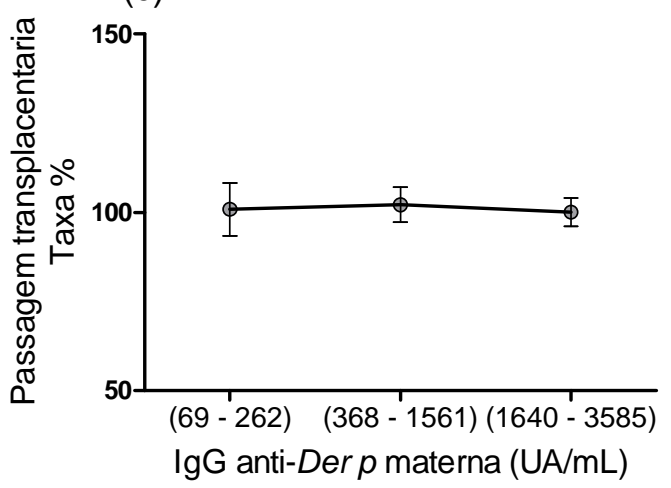

A concentração de IgG anti-Der $p$ foi determinada em amostras pareadas de soro materno e de cordão umbilical e os dados comparados de acordo com o estado atópico materno por teste de Mann-Whitney (a). A concentração de IgG anti-Der $p$ obtida no cordão umbilical foi correlacionada com a concentração sérica de suas respectivas mães por teste de Spearman (b). Taxa de passagem transplacentária em baixa, intermediária e alta concentração de IgG anti-Der $p$ materna (d). $\left({ }^{*}\right) p<0,05 ;\left({ }^{*}\right) p<0,01$

Calculamos para cada par de amostras de soro materno e do recém-nascido a taxa de passagem transplacentária, ou seja, a fração entre a concentração de anticorpos do soro de cordão umbilical e do soro materno.

Como podemos observar na tabela 7 , verificamos que a mediana da taxa de transferência da lgG anti-Der $p$ foi de $99 \%$ para o grupo de mães atópicas e $92 \%$ para o grupo de mães não atópicas. Ou seja, os recém-nascidos apresentaram níveis de lgG anti-Der $p$ bastante semelhantes aos de suas respectivas mães e a taxa de passagem transplacentária de lgG anti-Der $p$ não foi afetada pelos níveis de anticorpos maternos (Figura 6c). 
b) IgG específica ao Blo $t$ no cordão umbilical e soro materno

Assim como para o ácaro Der $p$, anticorpos IgG específicos ao Blo $t$ foram detectados em $100 \%$ das amostras de cordão umbilical analisadas e apresentaram níveis mais elevados em recém nascidos de mães atópicas. (figura 7a, tabela 8). Mães atópicas também apresentaram concentrações de $\lg G$ anti-Blo $t$ mais elevadas que mães não atópicas (Figura 7a e tabela 8). Figura 7- Concentração de $\operatorname{lgG}$ anti-Blo $t$ no soro materno e no cordão
umbilical

(a)

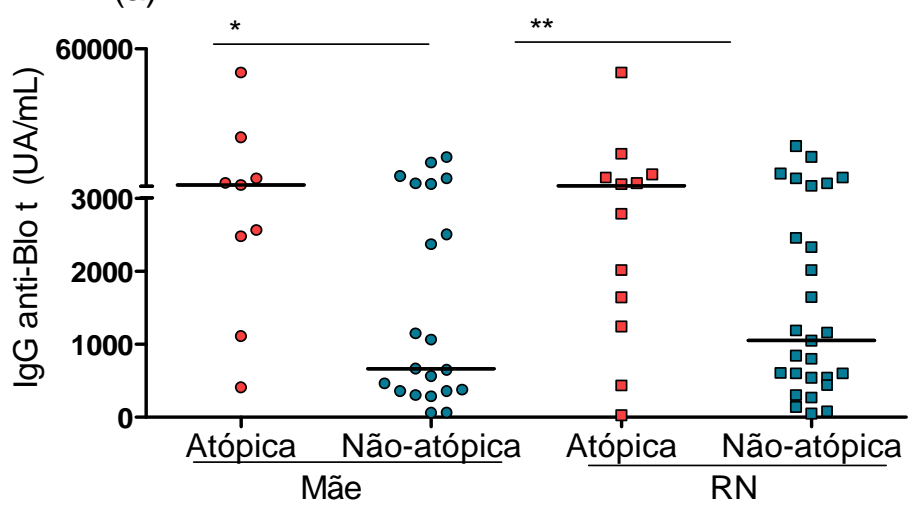

(b) IgG anti-Blot

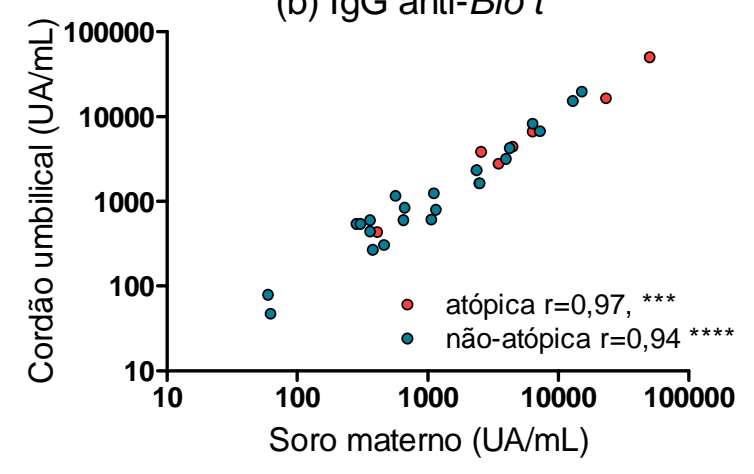

(C)

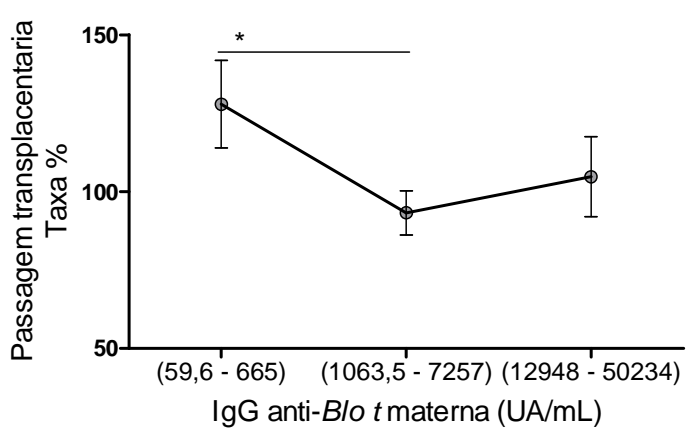

A concentração de $\lg G$ anti-Blo $t$ foi determinada em amostras pareadas de soro materno e de cordão umbilical e os dados comparados de acordo com o estado atópico materno por teste de Mann-Whitney (a). A concentração de $\operatorname{lgG}$ anti-Blo $t$ obtida no cordão umbilical foi correlacionada com a concentração sérica de suas respectivas mães por teste de Spearman (b). Taxa de passagem transplacentária em baixa, intermediária e alta concentração de lgG anti-Der $p$ materna (c). $\left({ }^{*}\right) p<0,05 ;\left({ }^{* *}\right) p<0,01$ 
Em ambos os grupos, observamos forte correlação entre os níveis de lgG anti-Blo $t$ no cordão umbilical e no soro materno (Figura $7 \mathrm{~b}$ ). A taxa de passagem transplacentária foi de $100 \%$, com tendência a cair à medida que os níveis de anticorpos maternos aumentam (figura 7c e tabela 8).

Tabela 8- Concentração de IgG total e anti-Blo $t$ no soro materno e de cordão umbilical

\begin{tabular}{lccc}
\hline & Mãe & $\begin{array}{c}\text { Cordão } \\
\text { umbilical }\end{array}$ & $\begin{array}{c}\text { Taxa passagem } \\
\text { transplacentária (\%) }\end{array}$ \\
\hline Atópica & & & \\
\hline IgG Total & 884 & 1065 & 118 \\
(mg/L) & $(569-1540)$ & $(735-1540)$ & $(67-154)$ \\
IgG anti-Blo $t$ & 3490 & 3323 & 100 \\
(UA/mL) & $(410-50234)$ & $(26,5-50234)$ & $(57-205)$ \\
\hline Não-atópica & & & 137 \\
\hline IgG Total & 815 & 986 & $(64-188)$ \\
(mg/L) & $(489-1150)$ & $(665-1390)$ & 100 \\
IgG anti- Blo $t$ & 665 & 1050 & $(57-205)$ \\
(UA/mL) & $(60-15180)$ & $(47-19712)$ & \\
\hline
\end{tabular}

A taxa de passagem transplacentária foi calculada para cada amostra pareada de soro materno e de cordão umbilical e está representada como mediana. Os valores entre parênteses representam o mínimo e o máximo de cada grupo.

c) IgG1, IgG2, IgG3 e IgG4 específica ao Der $p$ no cordão umbilical e soro materno

No presente estudo, verificamos passagem transplacentária das subclasses IgG1, IgG2 e IgG3 anti-Der $p$ em 100\% das amostras analisadas, independente da sensibilização materna ao mesmo ácaro. Em relação a $\lg G 4$ anti-Der $p$, apenas três recém-nascidos apresentaram níveis indetectáveis no codão umbilical. Destes, um pertencia ao grupo de mães atópicas, cuja concentração sérica foi $0,5 \mathrm{UA} / \mathrm{mL}$, e os outros dois ao grupo de mães não atópicas, com níveis séricos também indetectáveis. 
A concentração de IgG2 e IgG4 específicas ao $\operatorname{Der} p$, foi significativamente mais elevada nos recém-nascidos de mães atópicas quando comparados aos de mães não atópicas (figuras $8 b$ e 8d), enquanto que os níveis de lgG1 e lgG3 antiDer $p$ foram similares entre os grupos (figuras $8 \mathrm{a}$ e $8 \mathrm{c}$ ).

Assim como observado nos recém-nascidos, os níveis maternos de lgG2 e lgG4 anti-Der $p$ foram mais elevados no soro de mães atópicas quando comparados aos de mães não atópicas, enquanto que os níveis de lgG1 e lgG3 foram similares entre os grupos (figuras 8a-d).

Figura 8- Concentração de $\lg G 1$, IgG2, $\lg G 3$ e $\lg G 4$ anti-Der $p$ no grupo de mães atópicas e não atópicas

(a)

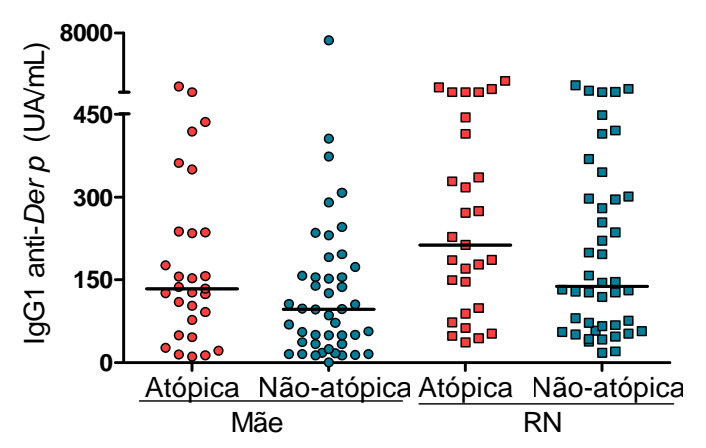

(c)

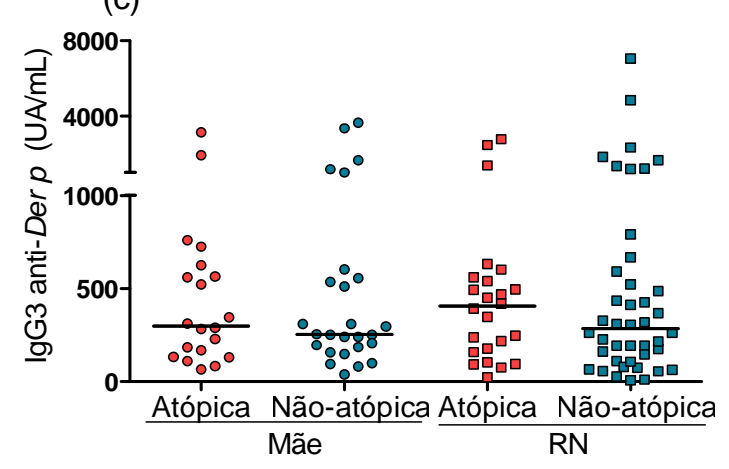

(b)

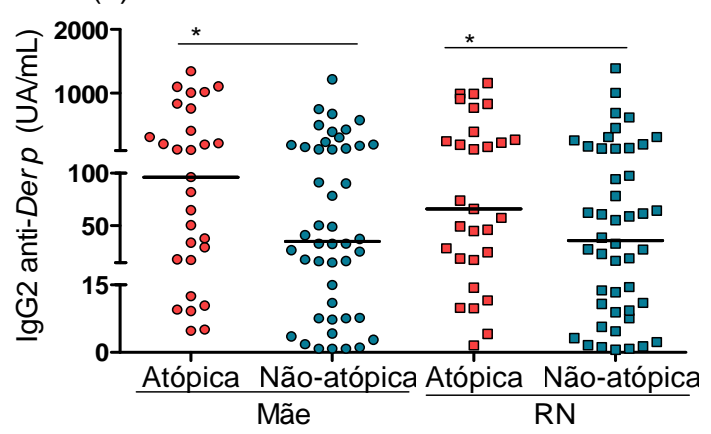

(d)

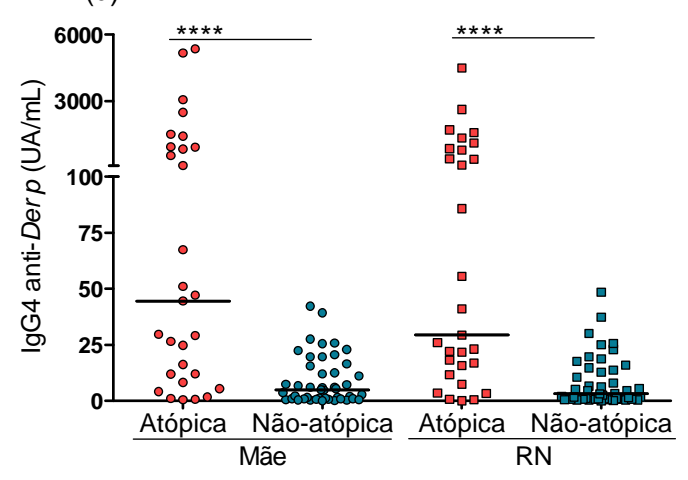

A concentração das subclasses de $\lg G$ anti-Der $p$ foi determinada em amostras pareadas de soro materno e de cordão umbilical e os dados comparados de acordo com o estado atópico materno por teste de Mann-Whitney (a-d). $\left(^{*}\right) p<0,05 ;\left({ }^{* * *}\right) p<0,0001$

Em nosso estudo a subclasse transferida com maior eficiência foi a $\lg G 1$, tanto para as mães atópicas como não-atópicas. A concentração de lgG1 anti-Der $p$ no cordão umbilical superou a do soro materno em ambos os grupos, chegando a ser mais que o triplo em alguns recém-nascidos (tabela 9; ANEXO B). No entanto, a 
taxa de passagem transplacentária foi similar entre as outras subclasses, não havendo diferença estatisticamente significativa (tabela 9). Em ambos os grupos as subclasses de IgG anti-Der $p$ do recém-nascido apresentaram forte correlação com a concentração de suas respectivas mães (figuras 9a-d).

\section{Figura 9- Concentração de IgG1, IgG2, IgG3 e IgG4 anti-Der p no soro materno e no cordão umbilical}

(a) IgG1 anti-Der $p$

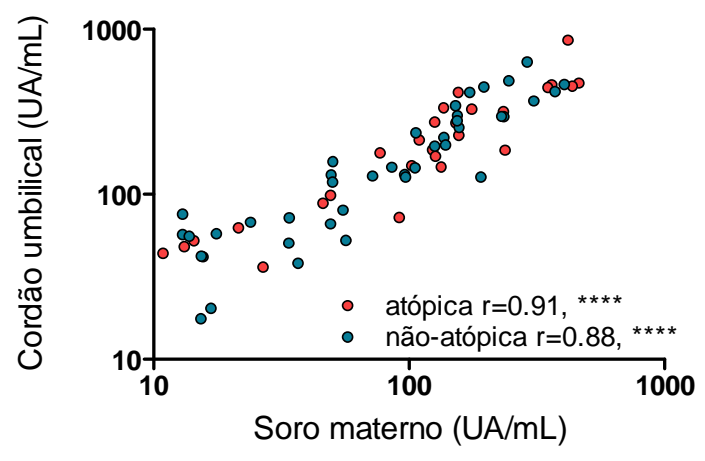

(c) IgG3 anti-Der $p$

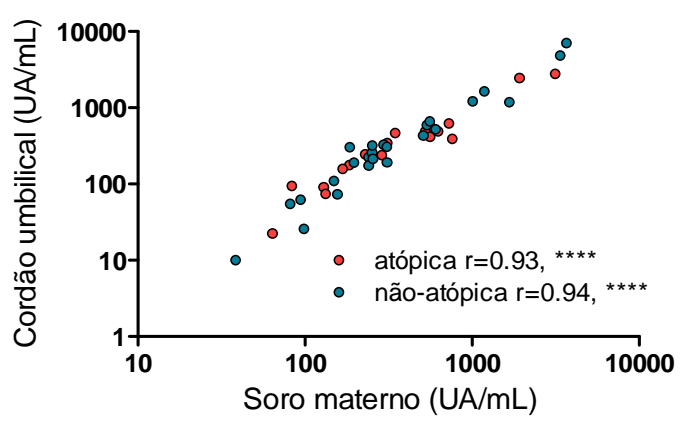

(b) IgG2 anti-Der $p$

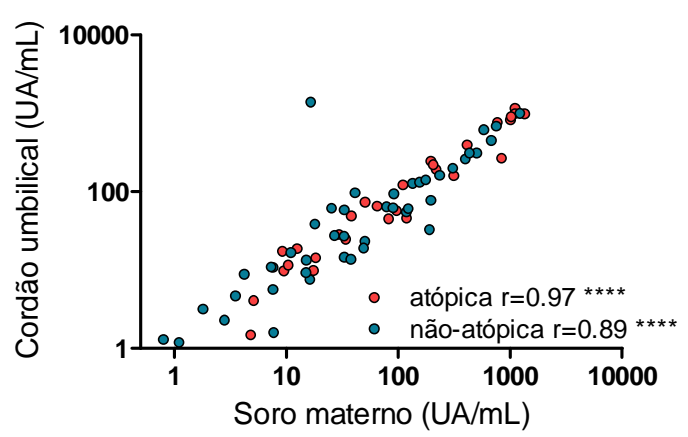

(d) IgG4 anti-Der $p$

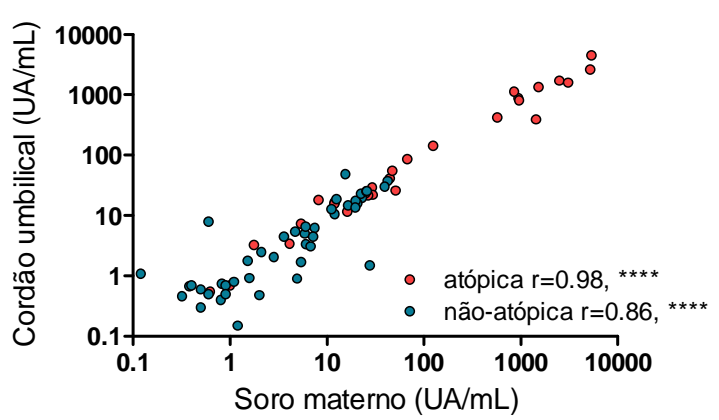

As subclasses de $\lg$ específicas ao Der $p$ quantificadas no cordão umbilical foram correlacionadas com as concentrações séricas de suas respectivas mães por teste de Spearman. $\left({ }^{*}\right) p<0,05 ;\left({ }^{* *}\right) p<0,01 ;\left({ }^{* *}\right) p<0,001 ;\left({ }^{* * *}\right) p<0,0001$.

Pudemos ainda observar que a taxa de passagem transplacentária das subclasses lgG1 e lgG2 apresentaram correlação inversa com os níveis de anticorpos maternos (Spearman $r=-0,4 p<0,001 ; r=-0,2, p=0,006$ para IgG1 e IgG2 respectivamente). Ou seja, a fração entre os níveis de anticorpos do recém-nascido e sua respectiva mãe diminui a medida que a concentração de anticorpos maternos aumenta (figuras 10a e 10b). Observamos a mesma tendência para a IgG4 anti-Der $p$ mas não para IgG3 anti-Der $p$ (figuras 10c e 10d). 
Figura 10- Taxa de passagem transplacentária para cada subclasse

(a)

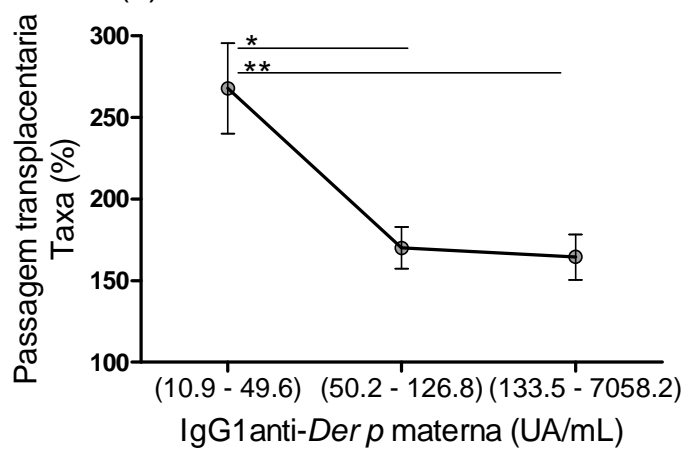

(c)

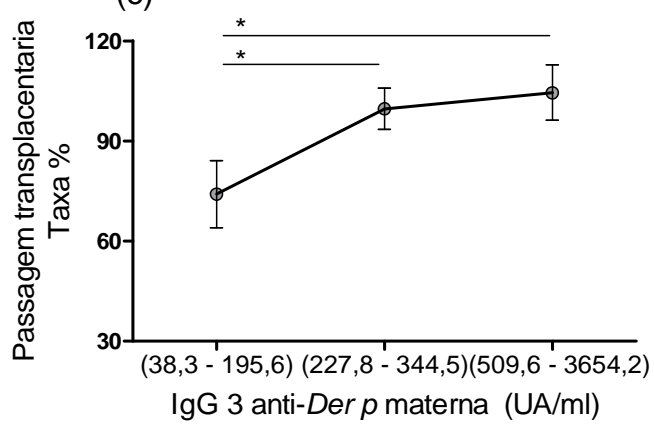

(b)

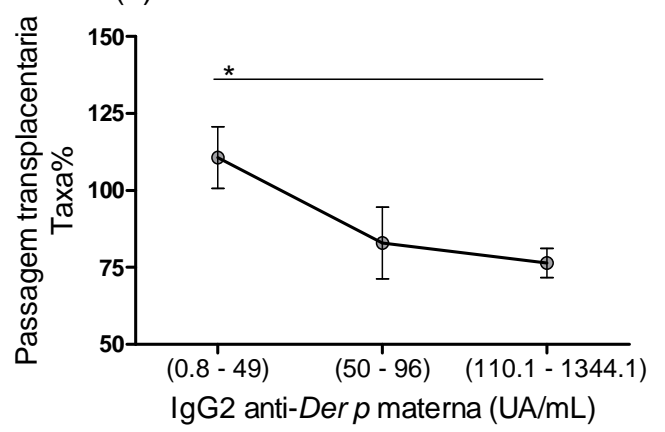

(d)

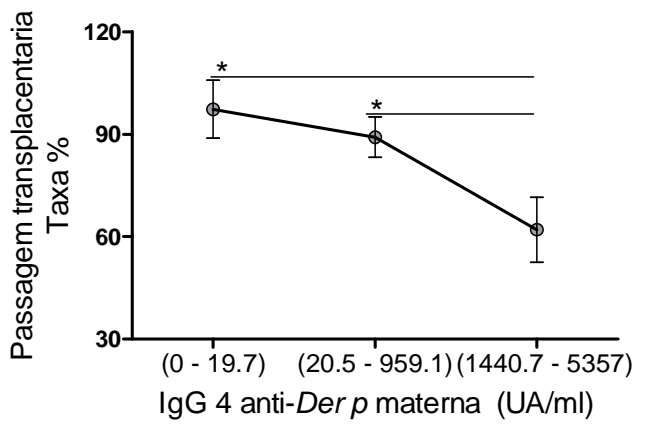

A taxa de passagem transplacentária de $\lg G 1$, $\lg G 2$, $\lg G 3$ e $\lg G 4$ específica ao Der $p$ foi comparada entre amostras de soro materno com baixa, intermediaria e alta concentração das subclasses de IgG anti-Der $p$ por teste Mann-Whitney (a-d) 


\section{Tabela 9- Concentração de IgG1, IgG2, IgG3 e IgG4 anti-Der $p$ no soro materno e no cordão umbilical}

\begin{tabular}{|c|c|c|c|c|}
\hline & Mãe & Cordão umbilical & $\begin{array}{c}\text { Taxa passagem } \\
\text { transplacentaria }(\%)\end{array}$ & \\
\hline \multicolumn{5}{|l|}{ Atopica $(n=29)$} \\
\hline \multirow[t]{2}{*}{ IgG1anti-Der $p$} & 133,5 & 213,1 & 178 & \\
\hline & $(10,9-1205)$ & $(36,2-1902)$ & $(78-463)$ & * \\
\hline \multirow[t]{2}{*}{$\lg$ G2anti-Der $p$} & 96 & 65,8 & $90\rfloor$ & * \\
\hline & $(4,8-1344)$ & $(1,5-1162)$ & $(31-189)$ & \\
\hline \multirow[t]{2}{*}{$\lg$ G3 anti-Der $p$} & 298 & 405,5 & 89 & \\
\hline & $(63,7-3133)$ & $(22,4-2780)$ & $(27-139)$ & \\
\hline \multirow[t]{2}{*}{ IgG4anti-Der p } & 44,6 & 29,4 & 89 & \lrcorner \\
\hline & $(0,5-5357)$ & $(0,0-4498)$ & $(0,0-222)$ & \\
\hline \multicolumn{5}{|c|}{ Não-atopica $(n=48)$} \\
\hline \multirow[t]{2}{*}{ IgG1anti-Der $p$} & 96,2 & 138,2 & 170 & \\
\hline & $(0-7058)$ & $(17,6-1366)$ & $(13-1398){ }_{*}^{*}$ & * \\
\hline \multirow[t]{2}{*}{ IgG2anti-Der $p$} & 35,3 & 35,9 & $82,5] *$ & $*$ \\
\hline & $(0,8-1219)$ & $(0,6-1393)$ & $(17-8441)$ & * \\
\hline \multirow[t]{2}{*}{$\lg G 3$ anti-Der $p$} & 252,7 & 284 & 96,5 & \\
\hline & $(38,3-3654)$ & $(6,7-7059)$ & $(26-193)$ & \\
\hline \multirow[t]{2}{*}{ IgG4anti-Der $p$} & 4,9 & 3,1 & 87 & 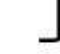 \\
\hline & $(0,0-42,3)$ & $(0,0-48,5)$ & $(5-1317)$ & \\
\hline
\end{tabular}

Os níveis de IgG anti-Der $p$ estão expressos em $U A / m L$. A taxa de passagem transplacentária foi calculada para cada amostra pareada de soro materno e de cordão umbilical e está representada como mediana. Os valores entre parênteses representam o mínimo e o máximo de cada grupo. Comparamos entre cada grupo (atópicas e nãoatópicas) a taxa de passagem transplacentaria da lgG1, $\lg G 2$, IgG3 e lgG4 (a-f). Teste Mann Whitney ${ }^{* * *} \mathrm{p}<0.0001$

\section{d) IgG1, IgG2, IgG3 e IgG4 específica ao Blo t no cordão umbilical e soro materno}

Em relação ao ácaro Blo $t$, quantificamos no cordão umbilical as subclasses IgG1 e IgG4 em 100\% das amostras analisadas. Já a lgG2 e lgG3 anti-Blo t estavam presentes em $79 \%$ e $93 \%$ dos recém-nascidos, respectivamente.

Das respectivas mães dos 11 recém-nascidos com níveis indetectáveis de lgG2 anti-Blo $t$ no cordão umbilical, apenas uma apresentou lgG2 anti-Blo $t$ sérica, mas em baixa concentração $(24,2 \mathrm{UA} / \mathrm{mL})$. Esta amostra pertence ao grupo de mães atópicas e todas as outras amostras negativas são de mães não atópicas. Os 3 recém-nascidos com níveis indetectáveis de lgG3 anti-Blo $t$ no cordão umbilical pertenciam ao grupo de mães não atópicas. Destas, duas apresentaram baixa 
concentração sérica de lgG3 anti-Blo $t$ (7,7 e 13,5 UA/mL) e uma não teve a amostra quantificada.

A concentração de $\lg G 1$ e $\operatorname{lgG} 2$ anti-Blo $t$ foi similar entre os grupo, tanto para mãe como para o recém-nascido (figuras 11a-b), enquanto que a lgG3 foi significativamente mais elevada nos recém-nascidos de mães atópicas (figura 11c). Já a lgG4 anti-Blo $t$ foi mais elevada no soro das mães atópicas e em seus respectivos recém-nascidos (figura 11d).

\section{Figura 11- Concentração de IgG1, IgG2, IgG3 e IgG4 anti-Blo $t$ no grupo de mães atópicas e não atópicas}

(a)

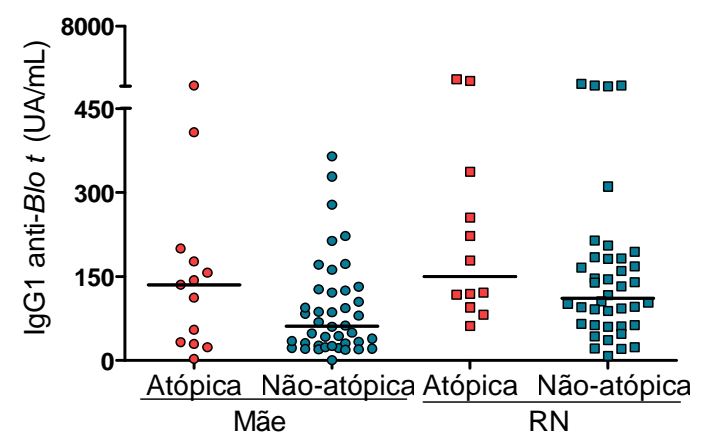

(c)

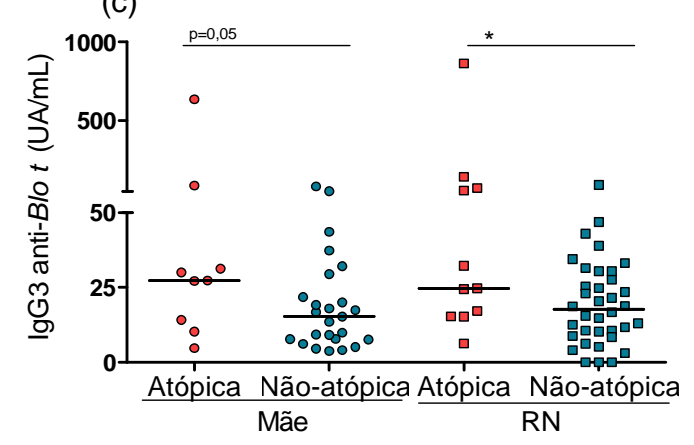

(b)

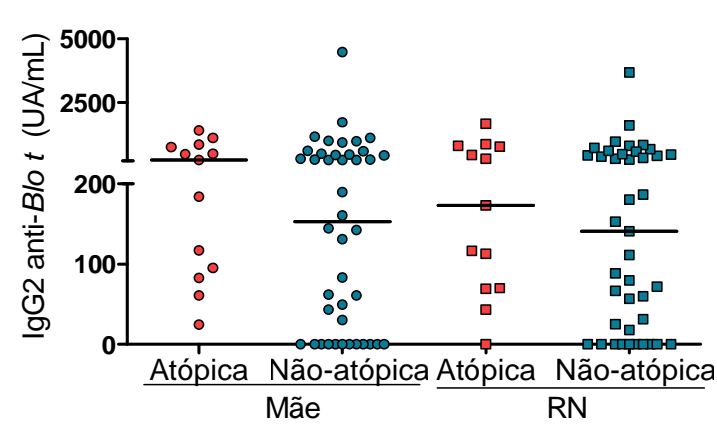

(d)

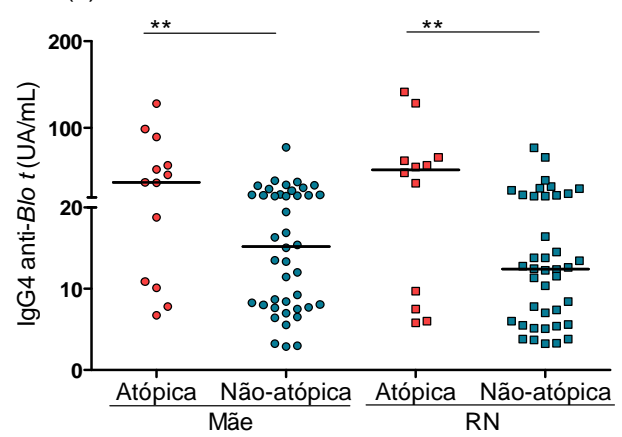

A concentração das subclasses de $\lg G$ anti-Der $p$ foi determinada em amostras pareadas de soro materno e de cordão umbilical e os dados comparados de acordo com o estado atópico materno por teste de Mann-Whitney (a-d). $\left({ }^{*}\right) p<0,05 ;\left({ }^{* *}\right) p<0,01$ 
Observamos forte correlação entre os níveis de anticorpos dos recémnascidos e de suas respectivas mães para todas as subclasses, em ambos os grupos (figuras 12a-d).

\section{Figura 12- Concentração de IgG1, IgG2, IgG3 e IgG4 anti-Blo $t$ no soro materno e no cordão umbilical}

(a) IgG1 anti-Blo $t$

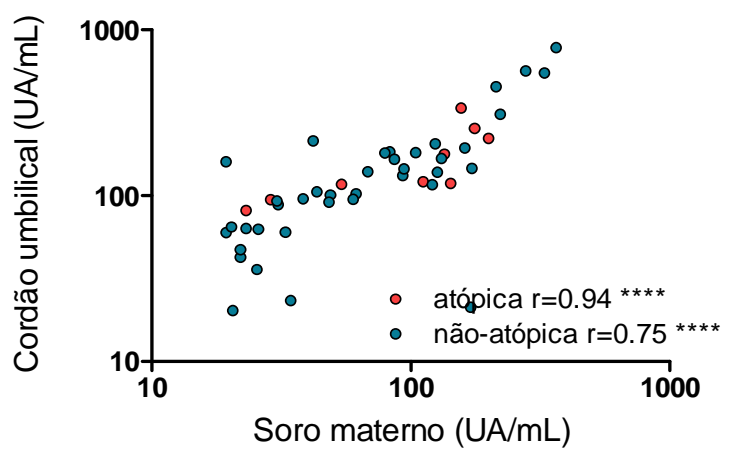

(c) IgG3 anti-Blo $t$

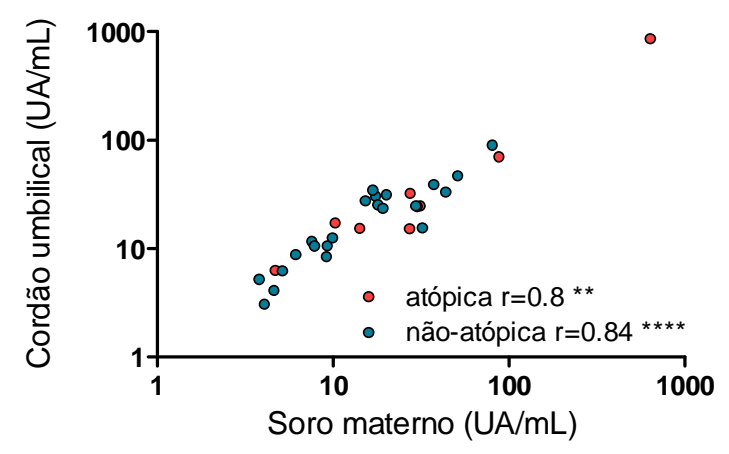

(b) lgG2 anti-Blo $t$

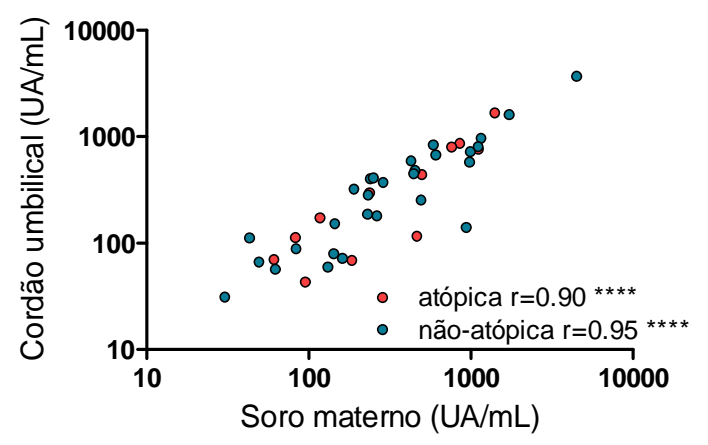

(d) IgG4 anti-Blo $t$

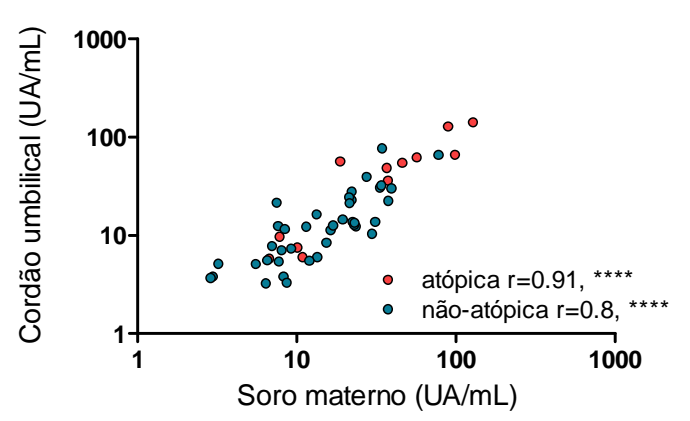

As subclasses de $\lg G$ específicas ao Blo $t$ quantificadas no cordão umbilical foram correlacionadas com as concentrações séricas de suas respectivas mães por teste de Spearman (a-d). $\left({ }^{* *}\right) p<0,01 ;\left({ }^{* * * *}\right) p<0,0001$.

A taxa de passagem transplacentária da lgG1 anti-Blo $t$ apresentou correlação inversa com os níveis de anticorpos maternos (Teste Spearman $r=-0,4, p=0,0003$ ). Apesar de não observarmos correlação inversa estatisticamente significativa para as outras subclasses, podemos observar nas figuras $13 a-d$, que estas também tendem a diminui à medida que a concentração de anticorpos maternos aumenta. 
Figura 13- Taxa de passagem transplacentária

(a)

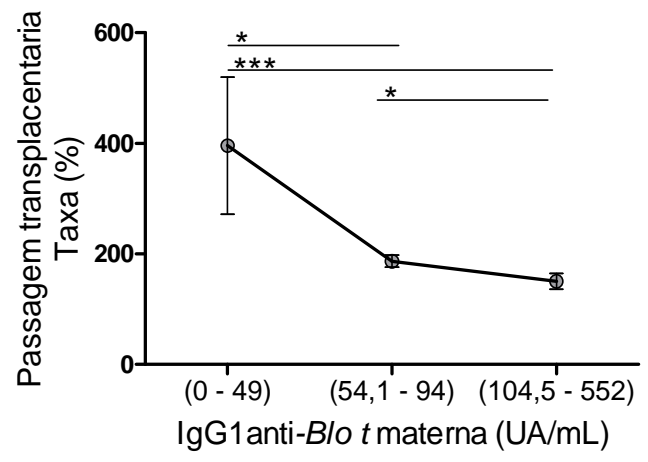

(c)

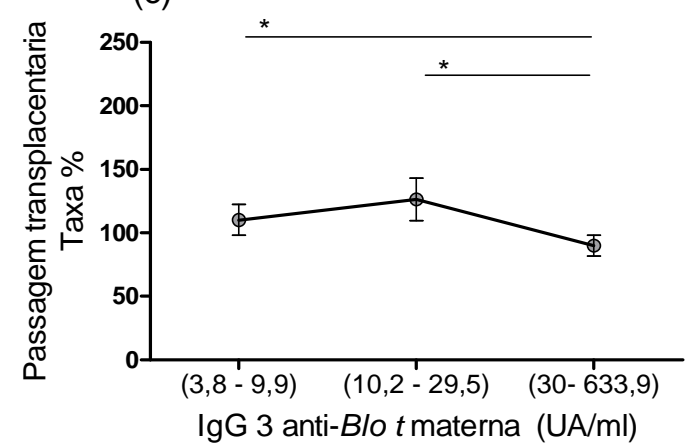

(b)

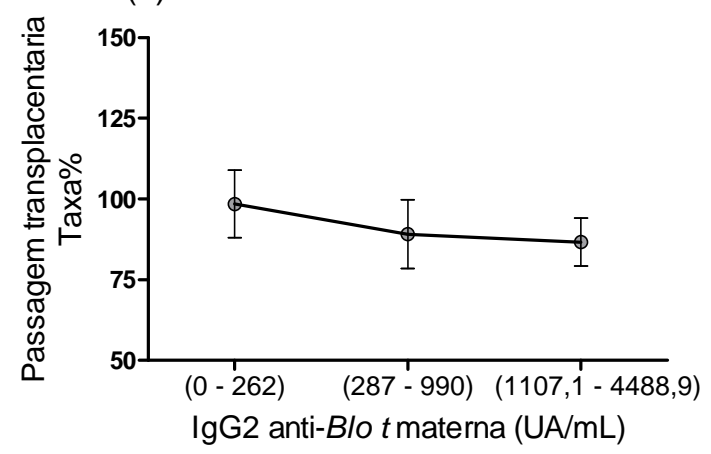

(d)

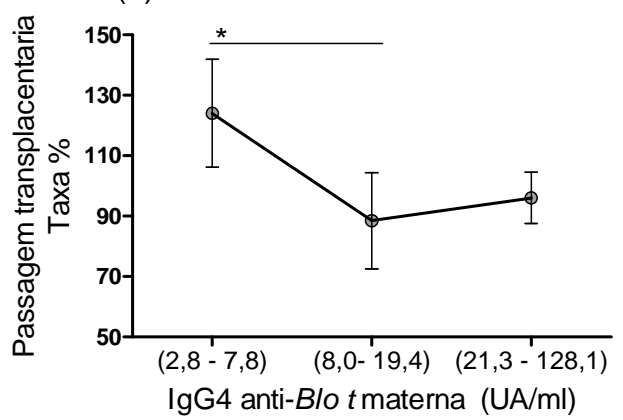

A taxa de passagem transplacentária de $\lg G 1$, $\lg G 2$, IgG3 e $\lg G 4$ específica ao Blo $t$ foi comparada entre amostras de soro materno com baixa, intermediaria e alta concentração das subclasses de IgG anti-Blo $t$ por teste Mann-Whitney (a-d). $\left(^{*}\right) p<0,05 ;\left({ }^{* * *}\right) p<0,001$ 
Assim como demonstramos para o ácaro Der $p$, a subclasse transferida com maior eficiência foi a lgG1 anti-Blo $t$ seguida pelas outras subclasses, cujas taxas foram similares (tabela 10).

Tabela 10- Concentração de IgG1, IgG2, IgG3 e IgG4 anti-Blo $t$ no soro materno e no cordão umbilical

\begin{tabular}{|c|c|c|c|c|}
\hline & Mãe & Cordão umbilical & $\begin{array}{c}\text { Taxa passagem } \\
\text { transplacentaria }(\%)\end{array}$ & \\
\hline \multicolumn{5}{|l|}{ Atopica $(n=13)$} \\
\hline \multirow[t]{2}{*}{ IgG1anti-Blo t } & 135 & 146,6 & 2127 & 7 \\
\hline & $(2,2-552)$ & $(61,1-1324)$ & $(83-2777)$ & \\
\hline \multirow[t]{2}{*}{ IgG2anti-Blo t } & 236 & 173,2 & $101]^{*}$ & 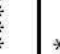 \\
\hline & $(24,2-1404)$ & $(0,0-1674)$ & $(0,0-147)$ & * \\
\hline \multirow[t]{2}{*}{$\lg G 3$ anti-Blo $t$} & 27,3 & 24,7 & 108 & \\
\hline & $(4,6-633,9)$ & $(6,2-861,7)$ & $(56-168)$ & \\
\hline \multirow[t]{2}{*}{ IgG4anti-Blo t } & 37,4 & 51,7 & 110 & 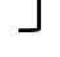 \\
\hline & $(6,7-128,2)$ & $(5,7-141,6)$ & $(55-303)$ & \\
\hline \multicolumn{5}{|c|}{ Não-atopica $(n=42)$} \\
\hline \multirow[t]{2}{*}{ IgG1anti-Blo t } & 60 & 110,8 & 192 & \\
\hline & $(0-364,2)$ & $(7,6-781)$ & $(12-828)) \stackrel{*}{*}$ & \\
\hline \multirow[t]{2}{*}{ IgG2anti-Blo t } & 152,7 & 141,1 & 97 & 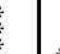 \\
\hline & $(0,0-4489)$ & $(0,0-90,1)$ & $(15-170)$ & \\
\hline \multirow[t]{2}{*}{$\lg G 3$ anti-Blo $t$} & 15,2 & 17,7 & 1187 & \\
\hline & $(3,8-80,3)$ & $(0,0-90,1)$ & $(0-205)$ & \\
\hline \multirow[t]{2}{*}{ IgG4anti-Blo t } & 15,2 & 12,4 & $85,2\rfloor$ & \rfloor \\
\hline & $(2,8-77,6)$ & $(3,2-77,1)$ & $(35-288)$ & \\
\hline
\end{tabular}

Os níveis de IgG anti-Blo $t$ estão expressos em $\mathrm{UA} / \mathrm{mL}$. A taxa de passagem transplacentária foi calculada para cada amostra pareada de soro materno e de cordão umbilical e está representada como mediana. Os valores entre parênteses representam o mínimo e o máximo de cada grupo. Comparamos entre caga grupo (atópicas e nãoatópicas) a taxa de passagem transplacentária da $\lg G 1$, IgG2, IgG3 e lgG4. Teste Mann Whitney ${ }^{*} p<0,05 ;{ }^{* * * *} p<0,0001$

\subsection{Transferência de alérgenos via passagem transplacentária}

Após verificarmos a passagem transplacentária de anticorpos maternos alérgenos-específicos, investigamos se os alérgenos ambientais também podem ser transferidos através da placenta. Quantificamos no cordão umbilical o Der $p 1$ e Blo $t$ 5, principais alérgenos dos ácaros Dermatophagoides pteronyssinus e Blomia tropicalis, respectivamente.

Detectamos o Der p 1 em 35,4\% das amostras analisadas. A concentração média foi de $37,5 \mathrm{pg} / \mathrm{mL}$ com máxima de $869,9 \mathrm{pg} / \mathrm{mL}$. Para o Blo 5 a concentração 
média foi de $100,7 \mathrm{~g} / \mathrm{mL}$ e a máxima de $1281 \mathrm{pg} / \mathrm{mL}$, mas a porcentagem de amostras positivas foi baixa, apenas $11,5 \%$. No entanto, é importante ressaltar que o limite de detecção do ensaio de ELISA para quantificação do $\operatorname{Der} p 1$ foi de $15 \mathrm{pg} / \mathrm{mL}$ enquanto que para o Blo $t 5$ foi de $125 \mathrm{pg} / \mathrm{mL}$. Portanto, se considerarmos o limite de $125 \mathrm{pg} / \mathrm{mL}$ para ambos os alérgenos, a porcentagem de amostras positivas ao Der $p$ 1 cairia para $4,8 \%$.

Verificamos fraca correlação entre os níveis de Der $p 1$ e Blo $t 5$ no cordão umbilical (teste Spearman $r=0,28 p=0,01$ ). No entanto, a concentração de alérgeno não esta correlacionada com os níveis dos respectivos anticorpos lgG específicos e suas subclasses, tanto na mãe como no cordão umbilical. Não houve diferença entre a concentração dos alérgenos Der $p 1$ e Blo t 5 quando comparados entre si (figura 14).

Figura 14- Concentração de Der p 1 e Blo $t 5$ no cordão umbilical

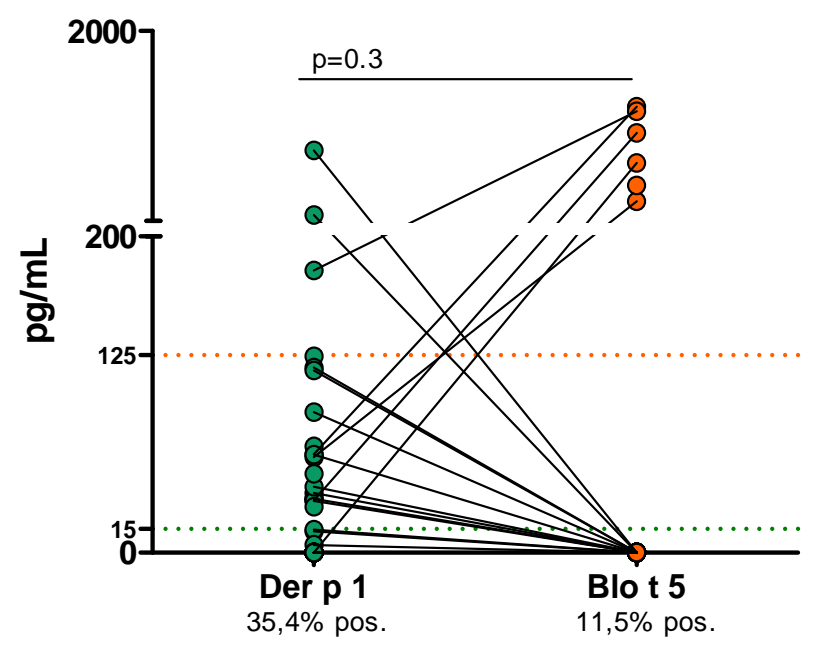

Para cada amostra de cordão umbilical as concentrações de Der $p 1$ e Blo $t 5$ foram determinadas e comparadas por teste de Wilcoxon. As linhas horizontais tracejadas representam o limite de detecção dos ensaios de ELISA para Der $p 1(15 \mathrm{pg} / \mathrm{mL}$-verde) e Blo $t 5(125 \mathrm{pg} / \mathrm{mL}$-laranja).

Também não houve diferença na concentração de alérgeno no cordão umbilical entre o grupo de mães atópicas e não atópicas, tanto de Der $p 1$ como de Blo $t 5$ (figura 15a e 15b). Por outro lado, observamos que para ambos os alérgenos a porcentagem de amostras positivas foi maior no grupo de mães atópicas. 
Figura 15- Concentração de Der $p 1$ e Blo $t 5$ no cordão umbilical

(a) $\operatorname{Derp} 1$

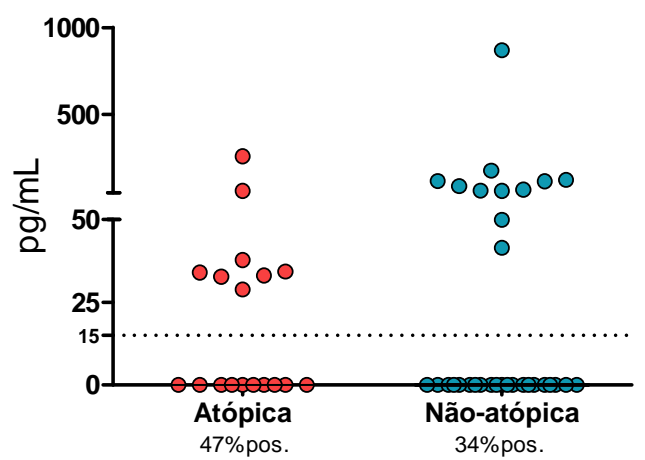

(b) Blot 5

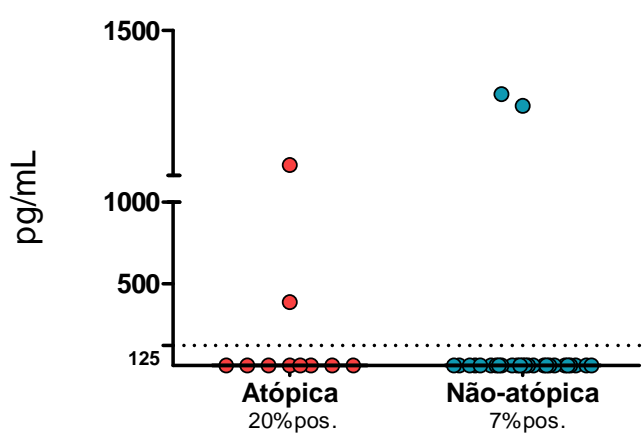

A concentração dos alérgenos foi determinada em amostras de cordão umbilical. Os dados foram comparados de acordo com o estado atópico materno (b-c) por teste de MannWhitney. As linhas horizontais tracejadas representam o limite de detecção dos ensaios de ELISA para (a) Der p $1(15 \mathrm{pg} / \mathrm{mL})$ e (b) Blo t5 (125pg/mL).

Tabela 11- Concentração de Der $p 1$ e Blo $t 5$ no cordão umbilical

\begin{tabular}{lccc}
\hline Der p 1 & $\begin{array}{c}\text { Amostras totais } \\
(\mathrm{n}=66)\end{array}$ & $\begin{array}{c}\text { Atópica } \\
(\mathrm{n}=18)\end{array}$ & $\begin{array}{c}\text { Não-atópica } \\
(\mathrm{n}=32)\end{array}$ \\
\hline & 37,58 & 28,8 & 55,5 \\
$(0,0-869,9)$ & $(0,0-258,9)$ & $(0,0-869,9)$ \\
Amostras & $30,6 \%$ & $47 \%$ & $3 \%$ \\
positivas (\%) & & &
\end{tabular}

\section{Blo 5}

\begin{tabular}{lccc}
\hline & $\begin{array}{c}\text { Amostras totais } \\
(\mathrm{n}=66)\end{array}$ & $\begin{array}{c}\text { Atópica } \\
(\mathrm{n}=10)\end{array}$ & $\begin{array}{c}\text { Não- atópica } \\
(\mathrm{n}=28)\end{array}$ \\
\hline $\begin{array}{c}84,46 \\
(0,0-1281)\end{array}$ & 142,5 & 90,04 \\
& $(0,0-1036)$ & $(0,0-1281)$ \\
Amostras & $9,6 \%$ & $20 \%$ & $7 \%$ \\
\hline
\end{tabular}

Os níveis de Der $p 1$ e Blo $t 5$ estão expressos em $\mathrm{pg} / \mathrm{mL}$. Os valores representam a média e entre parênteses o mínimo e o máximo de cada grupo. As amostras foram classificadas de acordo com o estado atópico materno. 


\subsection{Presença de IgM anti-Der $p$ e IgM anti-Blo $t$ no cordão umbilical}

Uma vez comprovada a transferência de alérgenos via placenta, quantificamos no cordão umbilical a presença de anticorpos $\operatorname{lgM}$ específicos aos ácaros Der $p$ e Blo t. Detectamos IgM anti-Der $p$ e $\operatorname{lgM}$ anti-Blo $t$ em todas as amostras analisadas, mas sem correlação com a concentração de alérgenos no cordão umbilical.

Também não houve diferença significativa na concentração de IgM quando comparamos recém-nascidos de mães atópicas aos de mães não atópicas, tanto para Der $p$ como para Blo $t$ (figura 16a-b).

\section{Figura 16- Concentração de IgM específica no cordão umbilical}
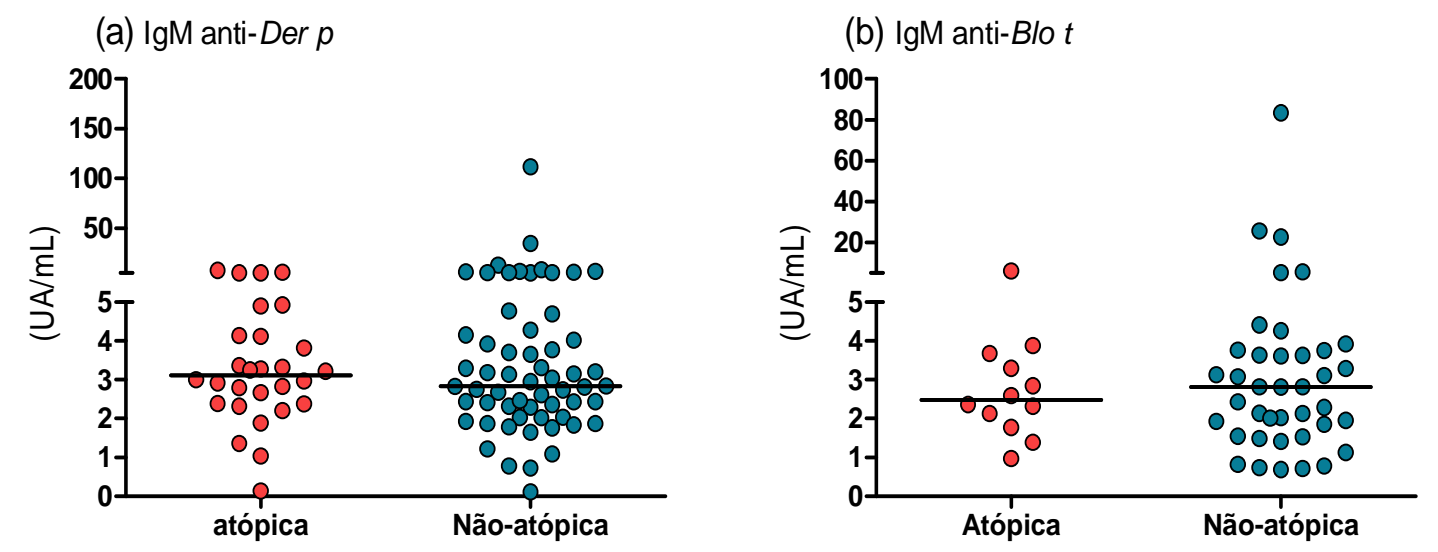

A concentração de IgM anti-Der $p$ (a) e IgM anti-Blo $t$ (b) foi determinada em amostras de cordão umbilical. Os dados foram comparados de acordo com o estado atópico materno por teste de Mann-Whitney. 


\subsection{Transferência de anticorpos alérgenos-específicos via aleitamento materno}

\section{a) IgG e IgA específica ao Der $p$ no colostro}

Detectamos $\lg \mathrm{A}$ anti-Der $p$ em todas as amostras de colostro analisadas. As concentrações de $\lg A$ total e $\lg A$ anti-Der $p$ no colostro foram extremamente variáveis (Tabela 12), mas apresentaram forte correlação entre si (Figura 17b). Ao investigarmos os níveis de lgA total e específica no colostro de mães sensibilizadas não encontramos diferença significativa quando comparadas às não sensibilizadas (Figura 17a). Como esperávamos, não observamos correlação entre os níveis de $\lg \mathrm{A}$ anti-Der $p$ no colostro e os níveis séricos de $\lg \mathrm{G}$ ou $\lg \mathrm{E}$, tanto totais como específicas ao Der $p$.

\section{Figura 17- Concentração de IgA total e anti-Der $p$ no colostro de mães atópicas e não atópicas}

(a)

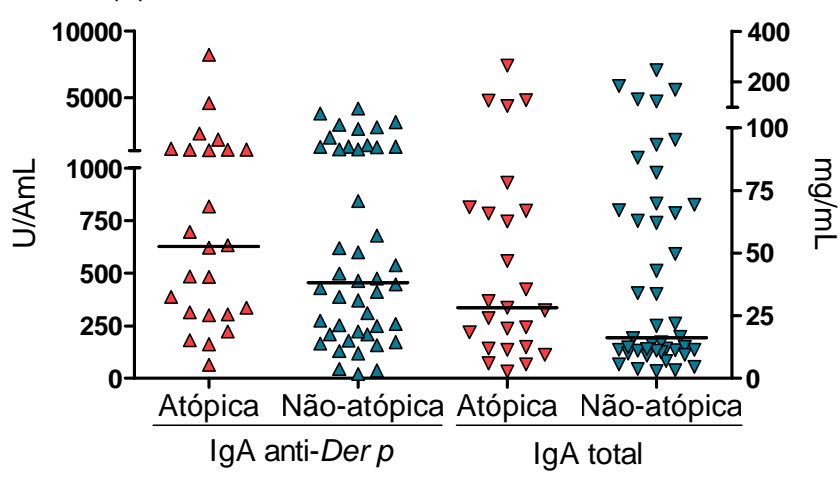

(b)

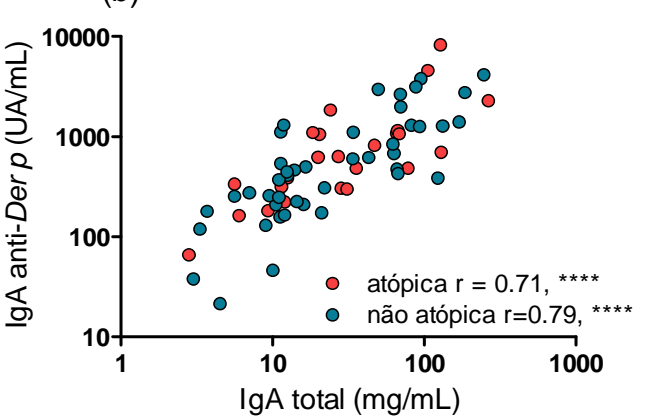

O nível de IgA total e IgA anti-Der $p$ foi determinado em amostras de colostro. Os dados foram comparados de acordo com o estado atópico materno por teste de Mann-Whitney. A concentração de $\lg A$ total esta expressa em $\mathrm{mg} / \mathrm{mL}$ (eixo $\mathrm{Y}$ a direita) e a concentração de $\lg \mathrm{A}$ anti-Der $p$ expressa em $\mathrm{UA} / \mathrm{mL}$ (eixo $\mathrm{Y}$ a esquerda) (a). A concentração de $\lg \mathrm{A}$ anti-Der $p$ foi correlacionada com a concentração de $\lg A$ total por teste de Spearman (b). $\left(^{* * * *}\right) p<0,0001$.

Uma vez que o switch de classe para $\lg A$ depende principalmente da presença do TGF-beta, quantificamos os níveis de TGF-beta no colostro e comparamos entre os dois grupos. A concentração de TGF-beta no colostro foi semelhante entre as mães atópicas e não atópicas (figura18a). Além disso, 
observamos que tanto a concentração de $\lg A$ total como a concentração de $\lg A$ específica apresenta correlação com os níveis de TGF-beta no colostro (figura 18).

\section{Figura 18- Concentrações de TGF-beta no colostro}

(a)

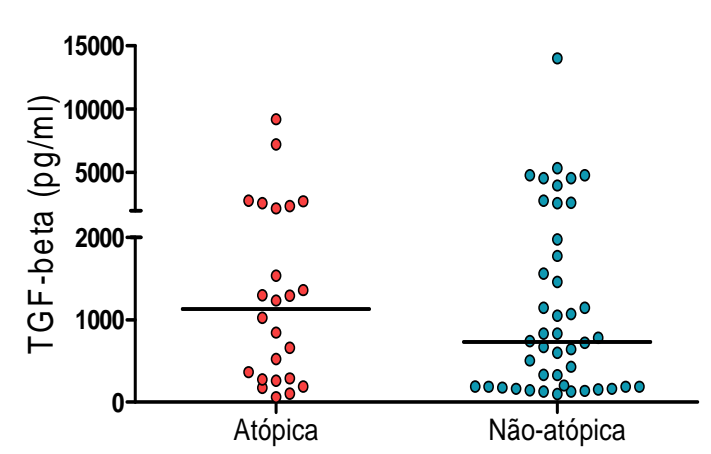

(c)

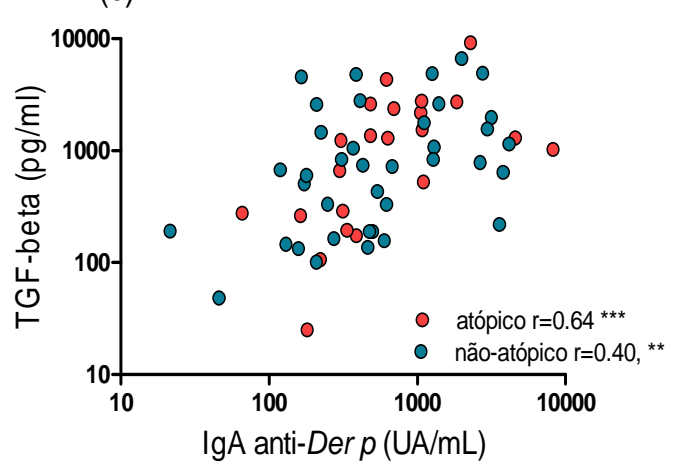

(b)

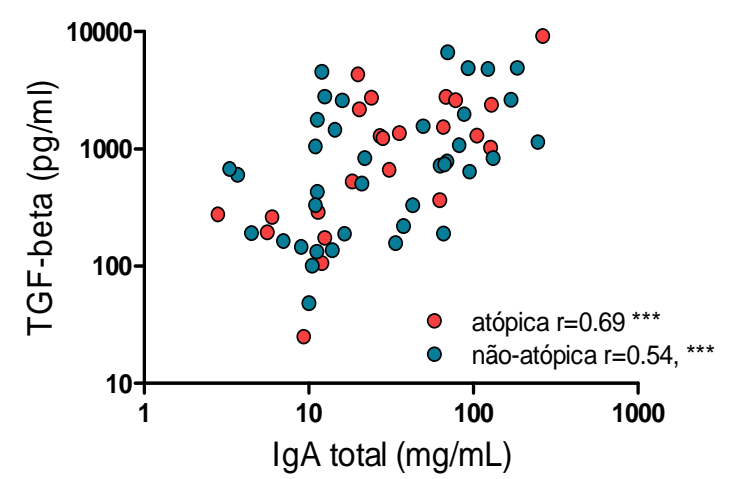

Os níveis de TGF-beta foram determinados em amostras de colostro por ELISA. Os dados obtidos no colostro de mães atópicas e mães não- atópicas foram comparados por teste Mann-Whitney (a). As concentrações de TGF-beta no colostro foram correlacionadas com os níveis de IgA total (b) e IgA anti-Der $p$ (c) por teste Spearman. $\left.{ }^{* * *}\right) p<0,001$

Com exceção de uma amostra que apresentou níveis abaixo de limite de detecção, surpreendentemente IgG anti-Der $p$ foi detectada em todas as amostras de colostro. Em relação à sensibilização materna, a concentração de IgG anti-Der $p$ no colostro foi maior em mães atópicas quando comparada às não-atópicas (figura 19a e tabela 12). Observamos ainda que a concentração de $\lg A$, tanto total como específica ao Der $p$ apresentou correlação com a lgG anti-Der $p$ no colostro em ambos os grupos (figura 19b-c). Já a concentração de lgG anti-Der $p$ sérica apresentou correlação com a lgG anti-Der $p$ de colostro apenas no grupo de mães não atópicas (figura 19d). 
Figura 19- Concentração de IgG anti-Der p no colostro

(a)

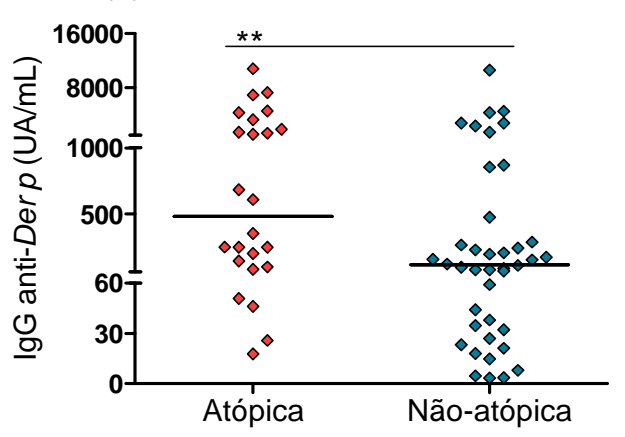

(c)

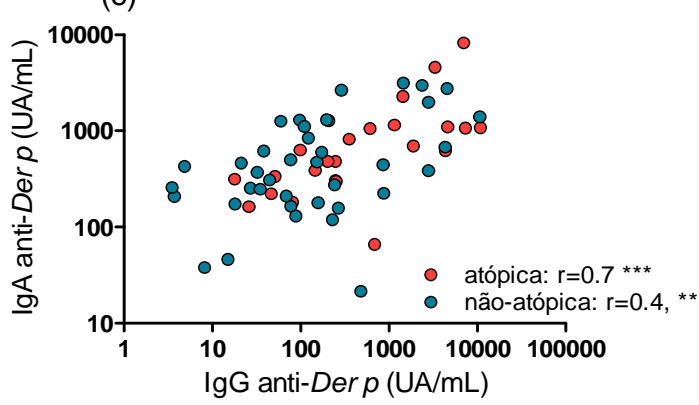

(b)

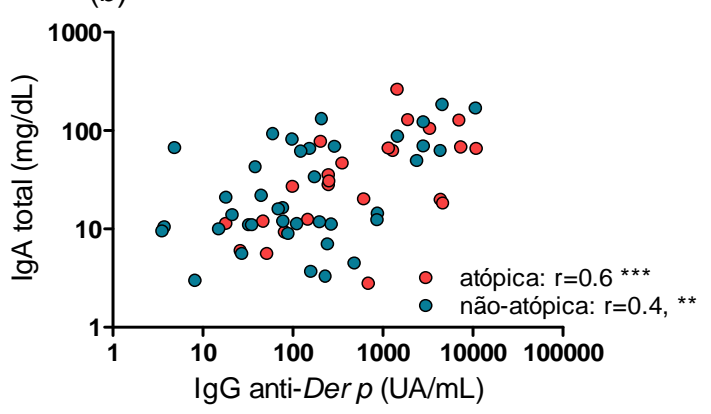

(d) $\lg G$ anti-Der $p$

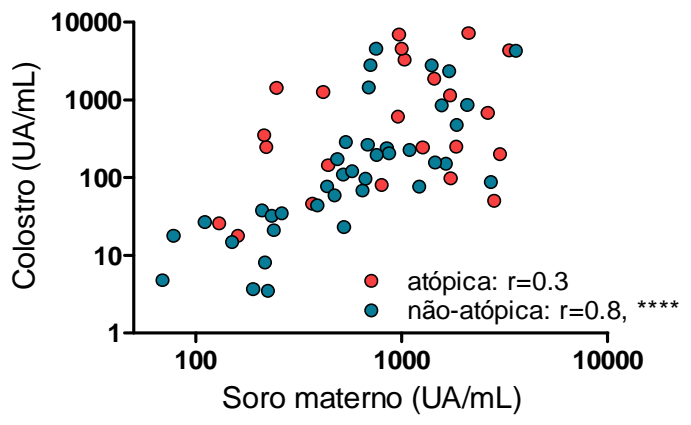

O nível de IgG anti-Der $p$ foi determinado em amostras de colostro. Os dados foram comparados de acordo com o estado atópico materno por teste de Mann-Whitney (a). Concentrações obtidas no colostro foram correlacionadas com concentrações de $\lg A$ total e IgA anti-Der $p$ de colostro (b-c) e com concentrações de IgG anti-Der $p$ dos respectivos soros maternos (d); todos por teste de Spearman. $\left({ }^{* *}\right) p<0,01 ;\left(^{* * *}\right) p<0,001 ;\left({ }^{* * *}\right) p<0,0001$.

Tabela 12- Concentração de $\lg A$ total, $\lg A$ anti-Der $p$ e $\lg G$ anti-Der $p$ no colostro

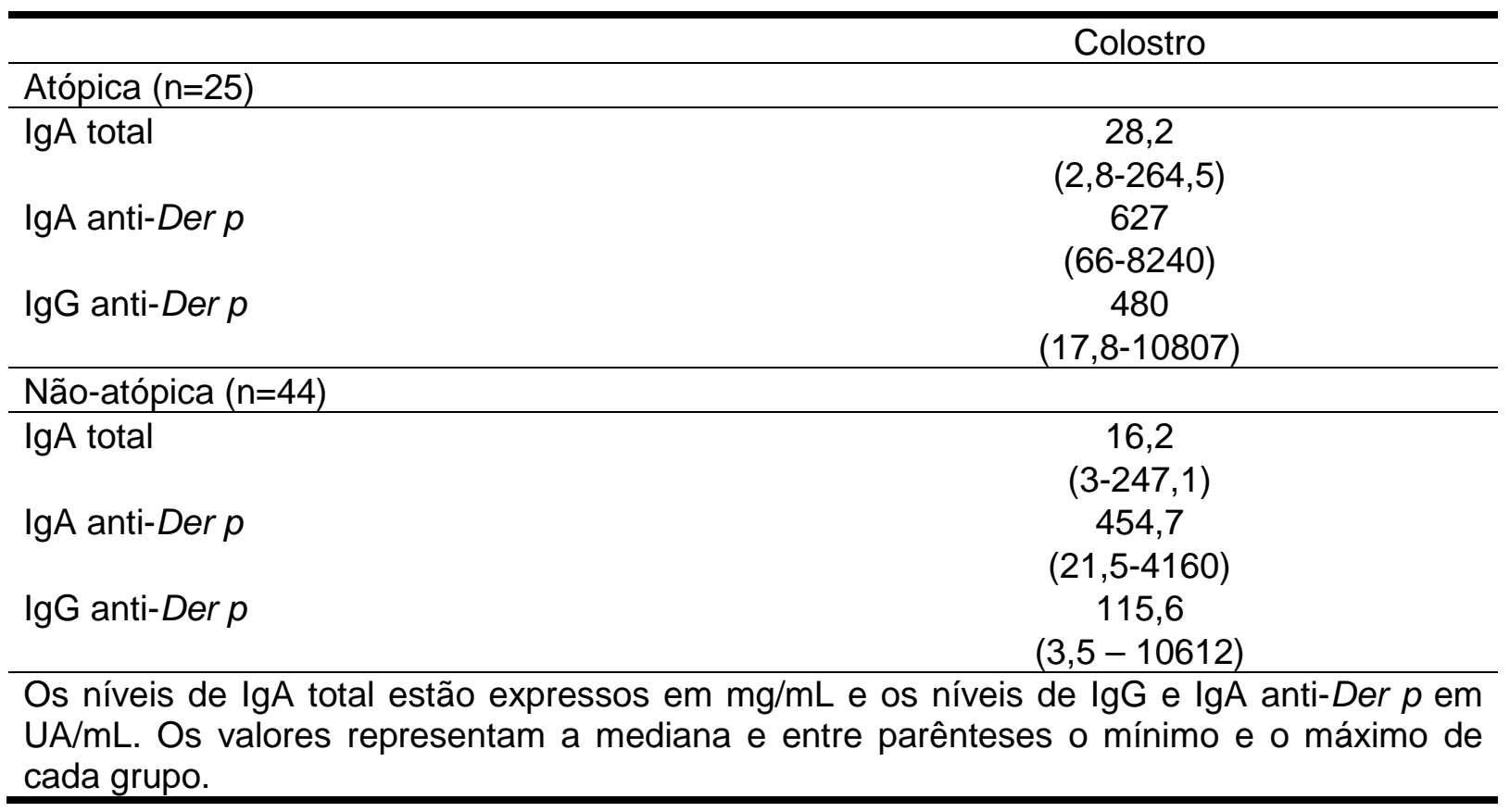




\section{b) IgG e IgA específica ao Blo $t$ no colostro}

Detectamos IgA anti-Blo $t$ em todas as amostras de colostro analisadas sem diferença entre os grupos (Figura20a) e forte correlação com as concentrações de IgA total (Figura 20b).

\section{Figura 20- Concentração de IgA total e anti-Blo $t$ no colostro de mães atópicas e não atópicas}
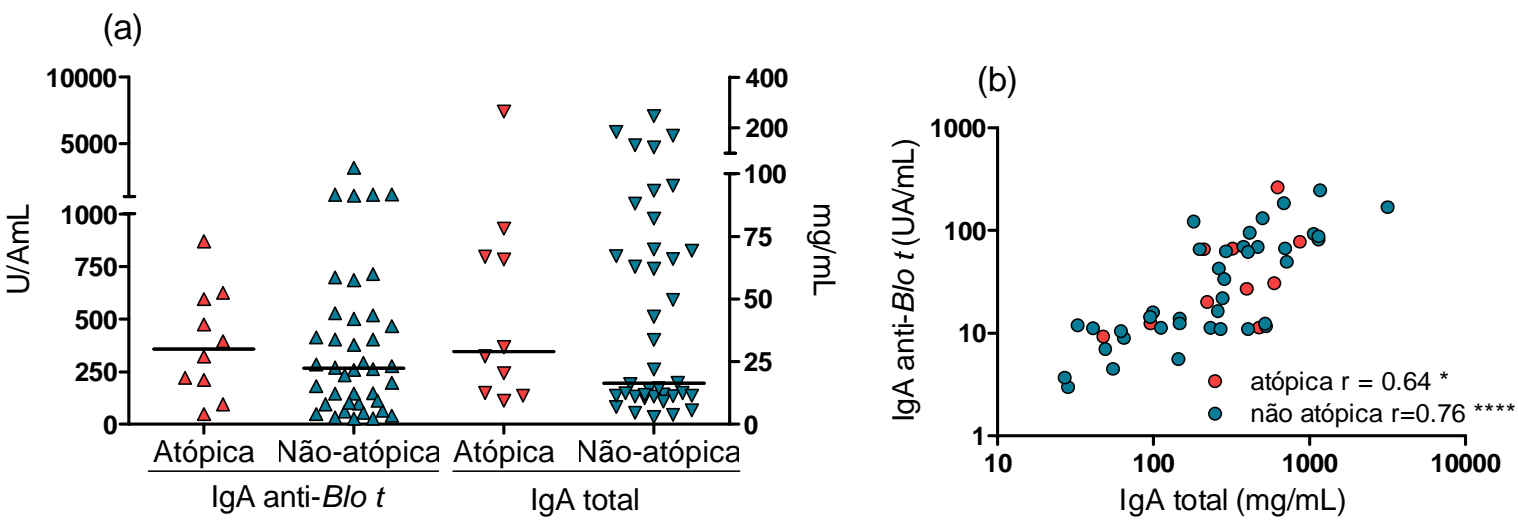

O nível de $\lg A$ total e $\lg \mathrm{A}$ anti-Blo $t$ foi determinado em amostras de colostro. Os dados foram comparados de acordo com o estado atópico materno por teste de Mann-Whitney. A concentração de $\lg A$ total esta expressa em $\mathrm{mg} / \mathrm{mL}$ (eixo $\mathrm{Y}$ a direita) e a concentração de $\lg \mathrm{A}$ anti-Blo $t$ expressa em $\mathrm{UA} / \mathrm{mL}$ (eixo $\mathrm{Y}$ a esquerda) (a). A concentração de $\lg \mathrm{A}$ anti- $B l o t$ foi correlacionada com a concentração de $\lg A$ total por teste de Spearman (b). $\left(^{*}\right) p<0,05$; $\left({ }^{* * *}\right) p<0,0001$.

Assim como para o ácaro Der p, a concentração de TGF-beta no colostro foi semelhante entre as mães sensibilizadas e não sensibilizadas (figura 21a) e apresentou correlação com os níveis de $\lg A$ total e $\lg A$ específica (figuras $21 b-c$ ). Também não observamos correlação entre os níveis de $\lg A$ anti-Blo $t$ no colostro e os níveis séricos de $\lg \mathrm{G}$ ou $\lg \mathrm{E}$, tanto totais como específicos.

Detectamos IgG anti-Blo $t$ em $96 \%$ das amostras de colostro, ou seja, apenas duas amostras apresentaram níveis abaixo de limite de detecção. Ambas pertenciam ao grupo de mães não atópicas, mas apresentaram níveis detectáveis de lgG antiDer $p$ no colostro (ANEXO B).

Em relação à sensibilização materna, apesar de cinco mães do grupo nãoatópicas apresentaram níveis elevadíssimos de $\lg G$ anti-Blo $t$, a concentração foi maior no grupo de mães atópicas (figura 22a). Se observarmos a tabela nos ANEXO $B$ e $C$, veremos que estas mesmas mães apresentaram níveis elevados de 
anticorpos em quase todas as quantificações, tanto no colostro como no soro. Como exemplo, podemos citar a mãe de número 46 que apresentou lgG anti-Blo $t$ no colostro na concentração de $15880 \mathrm{UA} / \mathrm{mL}$ e cujas concentrações séricas de lgG anti-Blo $t$ foram as máximas quantificadas, tanto na mãe como no recém-nascidos.

\section{Figura 21- Concentrações de TGF-beta no colostro}

(a)

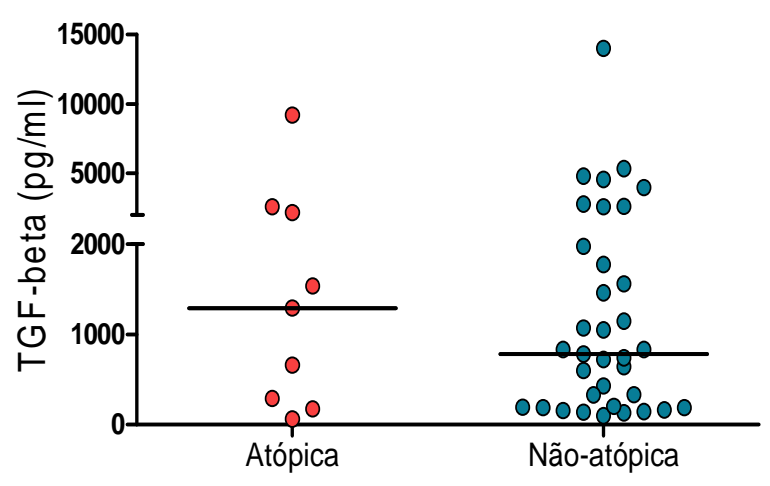

(b)

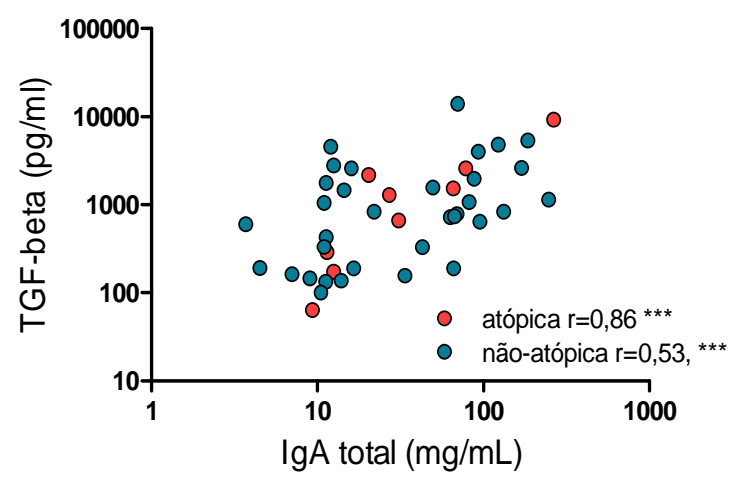

(c)

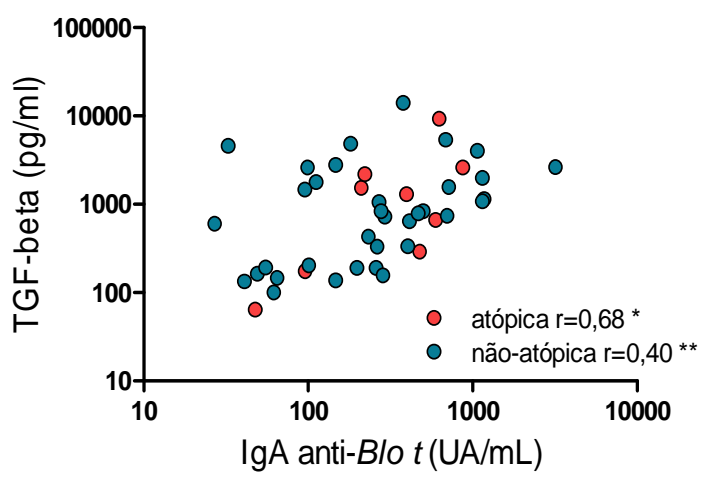

Os níveis de TGF-beta foram determinados em amostras de colostro por ELISA. Os dados obtidos no colostro de mães atópicas e mães não- atópicas foram comparados por teste Mann-Whitney (a). As concentrações de TGF-beta no colostro foram correlacionadas com os níveis de $\lg A$ total (b) e $\lg A$ anti-Blo $t$ (c) por teste Spearman. $\left.\left({ }^{*}\right) p<0,05 ;{ }^{* *}\right) p<0,01$; $\left(^{* * *}\right) p<0,001$

Observamos fraca correlação entre os níveis de lgG anti-Blo $t$ com a concentração de $\operatorname{lgA}$, total e específica no colostro apenas para o grupo de mães não-atópicas (figura22b e 22c). Não houve correlação entre a concentração de lgG anti-Blo $t$ sérica e a presente no colostro (figura $22 \mathrm{~d}$ ). 
Figura 22- Concentração de IgG anti-Blo $t$ no colostro

(a)

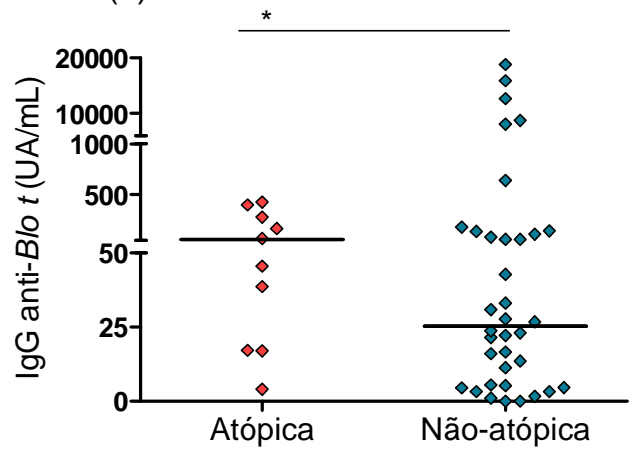

(c)

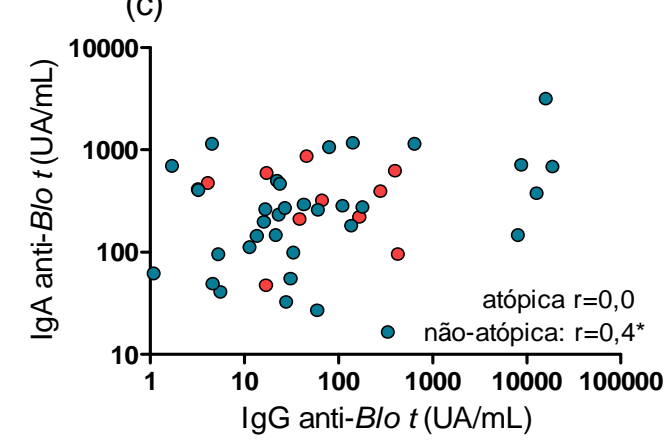

(b)

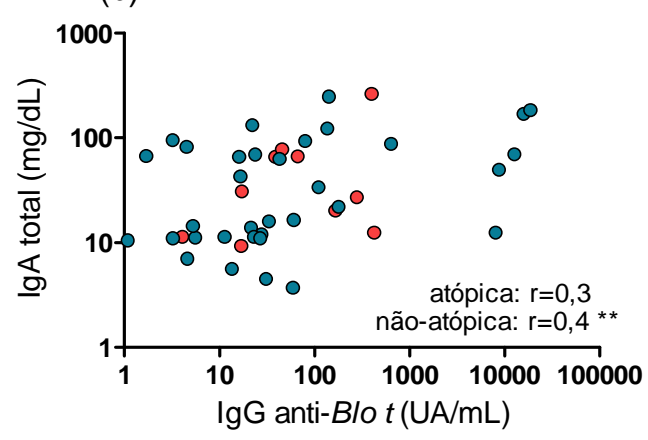

(d) IgG anti-Blot

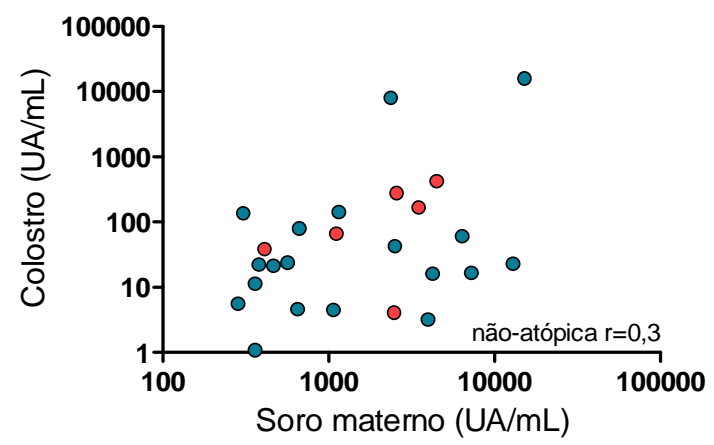

O nível de IgG anti-Blo $t$ foi determinado em amostras de colostro. Os dados foram comparados de acordo com o estado atópico materno por teste de Mann-Whitney (a). Concentrações obtidas no colostro foram correlacionadas com concentrações de IgA total e $\lg A$ anti- Blo $t$ de colostro (b-c) e com concentrações de lgG anti- Blo $t$ dos respectivos soros maternos (d); todos por teste de Spearman. $\left({ }^{*}\right) p<0,05 ;\left(^{* *}\right) p<0,01$

Tabela 13- Concentração de IgA total, IgA anti-Blo te $\lg G$ anti- Blo $t$ no colostro

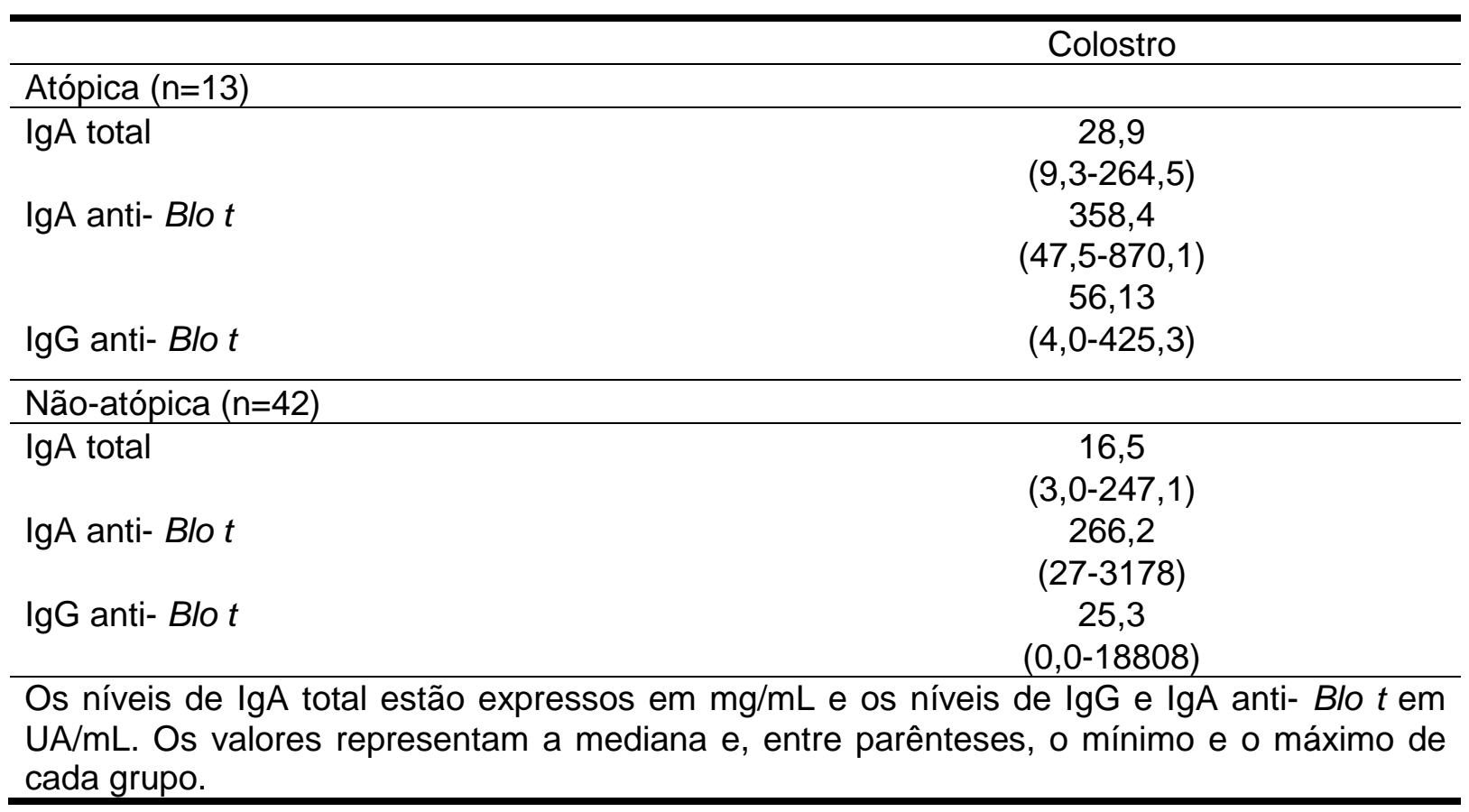




\subsection{Passagem de alérgenos livres via aleitamento materno}

a) Presença de Der $p 1$ e Blo $t 5$ no colostro

Investigamos a presença de Der p 1 e Blo $t 5$ em 75 amostras de colostro. Destas, 68\% foram positivas para o Der p 1 e 41,3\% positivas para o Blo $t 5$ (tabela 14). Conforme explicado anteriormente, a menor porcentagem de amostras positivas para o Blo $t 5$ em relação ao $\operatorname{Der} p 1$ se deve muito provavelmente a baixa sensibilidade do teste de ELISA para quantificação do Blo $t$ 5. Assim como observado no cordão umbilical, a concentração de Blo $t 5$ no colostro foi maior em relação à de Der $p 1$ (figura 23) e houve correlação positiva entre os níveis de Der $p$ 1 e Blo $t 5$ no colostro (teste Spearman $r=0,28 p=0,008$ ).

Figura 23- Concentração de alérgeno ambiental no colostro

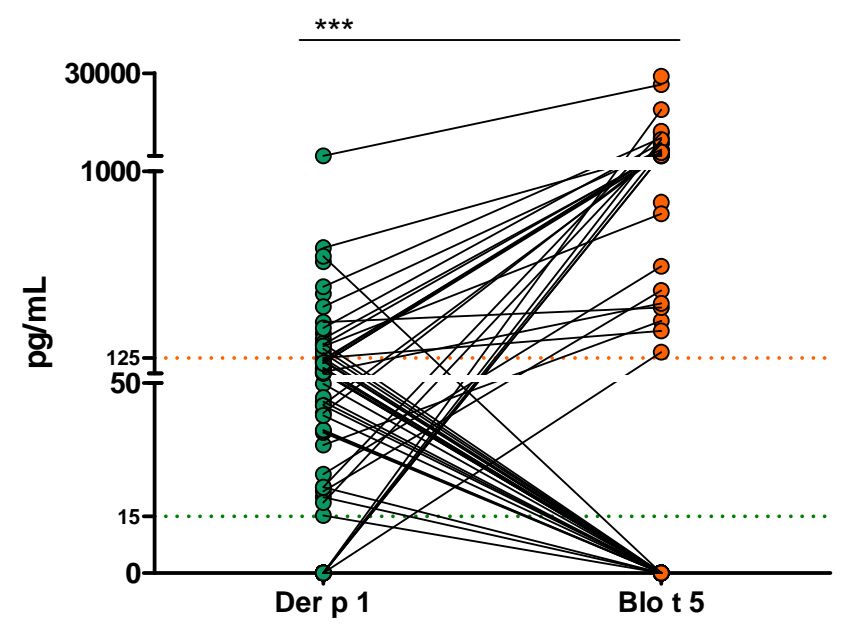

Para cada amostra de colostro as concentrações de Der $p 1$ e Blo $t 5$ foram determinadas e comparadas por teste de Wilcoxon (a). As linhas horizontais tracejadas representam o limite de detecção do ensaio de ELISA para Der p 1 (15 pg/mL-verde) e Blo t 5 (125 pg/mLlaranja). $\left.{ }^{* \star *}\right) \mathrm{p}<0,001$ 
Tabela 14- Concentração de Der p 1 e Blo $t 5$ no colostro

\begin{tabular}{|c|c|c|c|}
\hline \multicolumn{4}{|l|}{ Derp 1} \\
\hline & $\begin{array}{c}\text { Amostras totais } \\
(\mathrm{n}=75)\end{array}$ & $\begin{array}{l}\text { Atópica } \\
(\mathrm{n}=20)\end{array}$ & $\begin{array}{c}\text { Não-atópica } \\
(\mathrm{n}=43)\end{array}$ \\
\hline & $\begin{array}{c}108,5 \\
(0,0-1126)\end{array}$ & $\begin{array}{c}256 \\
(20-1126)\end{array}$ & $\begin{array}{c}64,9 \\
(0,0-364,5)\end{array}$ \\
\hline $\begin{array}{l}\text { Amostras } \\
\text { positivas (\%) }\end{array}$ & $68 \%$ & $100 \%$ & $58,1 \%$ \\
\hline \multicolumn{4}{|l|}{ Blo t 5} \\
\hline & $\begin{array}{c}\text { Amostras totais } \\
(n=75)\end{array}$ & $\begin{array}{c}\text { Atópica } \\
(\mathrm{n}=8)\end{array}$ & $\begin{array}{c}\text { Não- atópica } \\
(\mathrm{n}=38)\end{array}$ \\
\hline & $\begin{array}{c}1953 \\
(0,0-28890)\end{array}$ & $\begin{array}{c}1176 \\
(0,0-7271)\end{array}$ & $\begin{array}{c}1536 \\
(0,0-17201)\end{array}$ \\
\hline $\begin{array}{l}\text { Amostras } \\
\text { positivas (\%) }\end{array}$ & $41,3 \%$ & $25 \%$ & $43,5 \%$ \\
\hline
\end{tabular}

Os níveis de Der $p 1$ e Blo $t 5$ estão expressos em $\mathrm{pg} / \mathrm{mL}$. Os valores representam a média e entre parênteses o mínimo e o máximo de cada grupo. As amostras foram classificadas de acordo com o estado atópico materno.

Também analisamos as amostras em relação ao estado atópico materno. No grupo de mães atópicas, a porcentagem de amostras positivas para o $\operatorname{Der} p 1$ foi de $100 \%$ (tabela 14) e apresentou maior concentração quando comparado ao grupo de mães não atópicas (figura 24a). Observamos ainda fraca correlação positiva entre a concentração de $\operatorname{Der} p 1$ e os níveis de lgG específicos no colostro e soro materno (Teste Spearman $r=0,36 p=0,0009$ e $r=0,2 p=0,001$, respectivamente). Tanto para o Der $p 1$ como para Blo $t 5$, não houve correlação entre a concentração de alérgeno e os níveis de IgA específica no colostro.

Em relação ao Blo $t 5$, a porcentagem de amostras positivas no grupo de mães atópicas foi $25 \%$ e não houve diferença significativa entre ambos os grupos (figura 24b). Também não observamos correlação positiva entre a concentração de Blo $t 5$ e os níveis de lgG específicos no colostro ou soro materno.

Comparamos a concentração de alérgeno presente no colostro com a detectada nas respectivas amostras de cordão umbilical e verificamos que, para ambos os ácaros, a concentração é mais elevada no colostro (figura 25a-b).

Além de investigarmos a presença de alérgenos ambientais em amostras de colostro, verificamos a presença dos mesmos no leite materno.

Tivemos acesso à 33 amostras as quais foram coletadas na Fraça e Bélgica no período de uma semana à 4 meses após o parto. Quantificamos a presença de 
Der $p 1$ e verificamos que 42,4\% das amostras apresentaram níveis detectáveis (tabela 15). A concentração média foi $16,9 \mathrm{pg} / \mathrm{mL}$, significativamente mais baixa que a concentração de Der $p 1$ no colostro (figura 26a). De acordo com este dado, observamos que amostras de leite coletadas logo na primeira semana após o parto apresentaram concentrações mais elevadas que as coletadas posteriormente (figura 26b).

Figura 24- Concentração de alérgeno ambiental no colostro

(a) $\operatorname{Der} p 1$

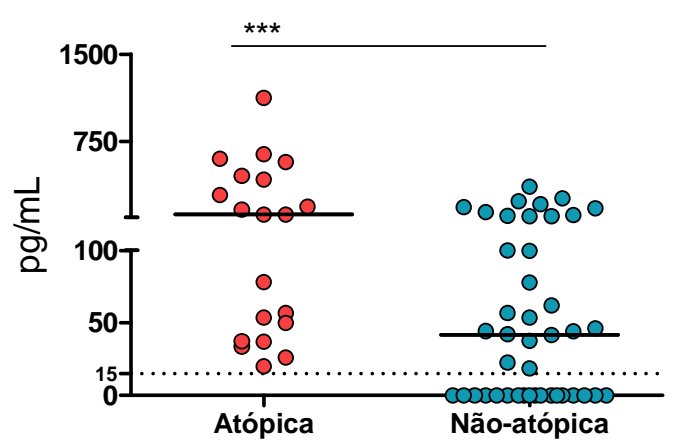

(b) Blo t5

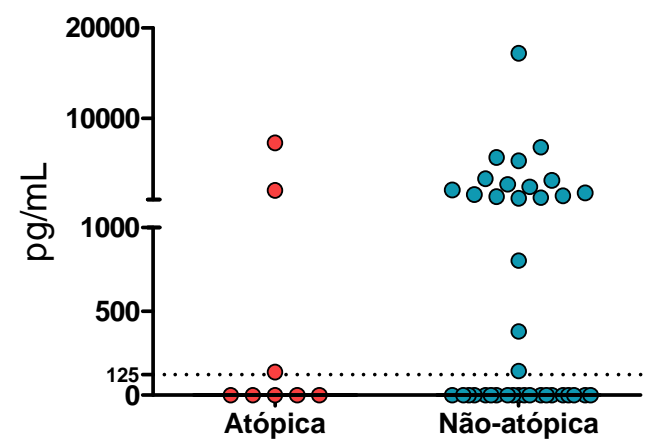

A concentração de Der $p 1$ e Blo $t 5$ foi determinada em amostras de colostro e os dados comparados de acordo com o estado atópico materno ao Der $p$ (a) e Blo $t$ (b) por teste de Mann-Whitney. As linhas horizontais tracejadas representam o limite de detecção do ensaio de ELISA para Der $p 1$ (15pg/mL-verde) e Blo 5 (125pg/mL-laranja). $\left({ }^{* \star *}\right) \mathrm{p}<0,001$

Figura 25- Concentração de alérgeno ambiental no colostro e cordão umbilical
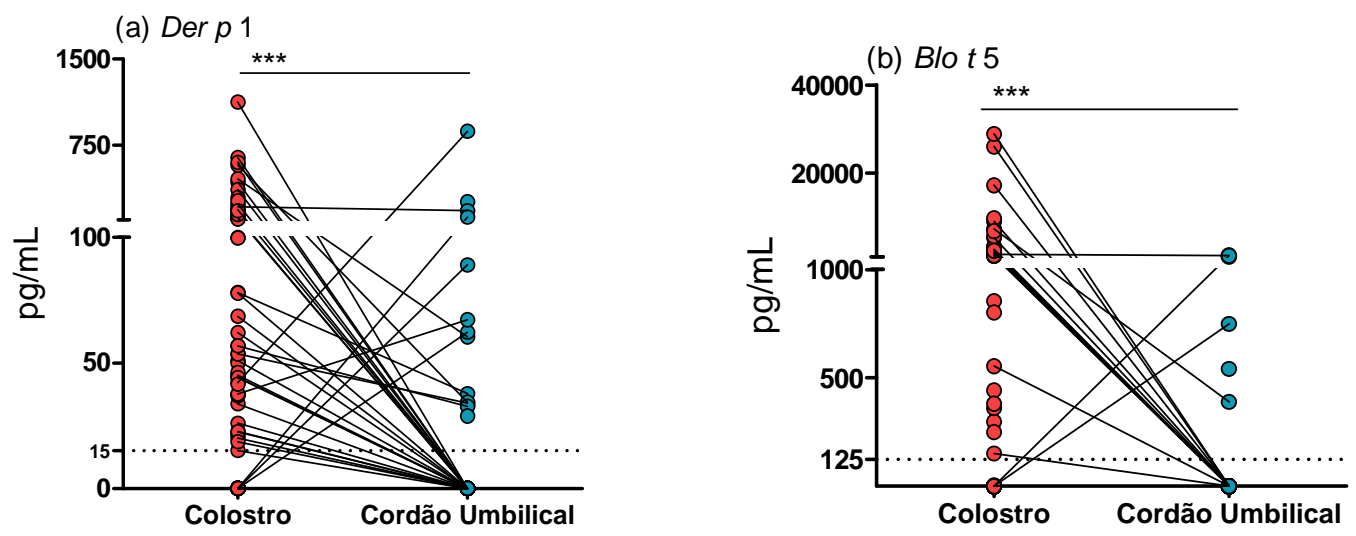

A concentração de $\operatorname{Der} p 1$ (a) e Blo $t 5$ (b) foram comparada entre amostras pareadas de colostro e cordão umbilical por teste de Wilcoxon. As linhas horizontais tracejadas representam o limite de detecção do ensaio de ELISA. $\left({ }^{* * *}\right) p<0,001$ 
Figura 26- Concentração de $\operatorname{Der} p 1$ no colostro e leite

(a) $\operatorname{Der} p 1$

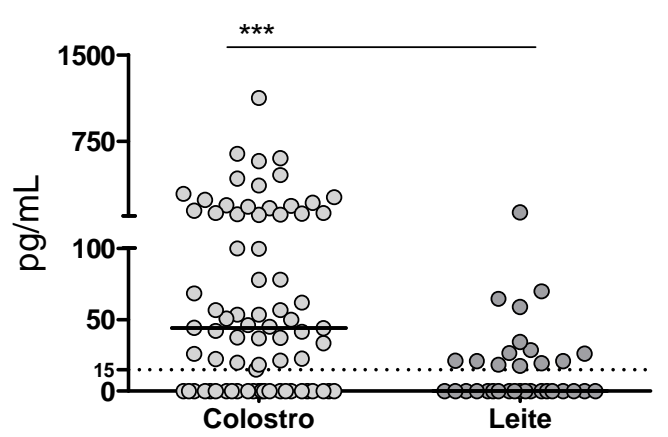

(b) Der $p 1$ no leite

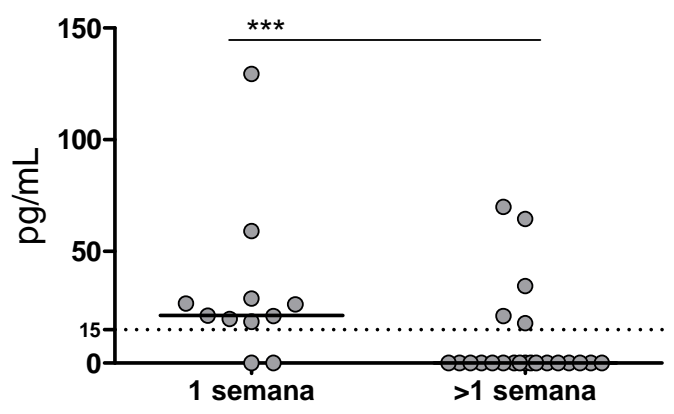

A concentração de Der $p 1$ foi determinada em amostras de colostro e leite materno. A concentração de Der $p 1$ no colostro foi comparada com a concentração no leite por teste de Mann-Whitney (a). A concentração de Der $p 1$ no leite foi comparada de acordo com o período de coleta da amostra (b) por teste de Mann-Whitney. As linhas horizontais tracejadas representam o limite de detecção do ensaio de ELISA. $\left({ }^{* * *}\right) p<0,001$

Tabela 15- Concentração de $\operatorname{Der} p 1$ no leite humano

\begin{tabular}{lccc}
\hline \multicolumn{1}{l}{ Der $\boldsymbol{p} 1$ no leite humano } & & \\
\hline & $\begin{array}{c}\text { Amostras totais } \\
(\mathrm{n}=33)\end{array}$ & $\begin{array}{c}1 \text { semana } \\
(\mathrm{n}=11)\end{array}$ & $\begin{array}{c}\text { semana } \\
(\mathrm{n}=22)\end{array}$ \\
\hline & 16,9 & 31,9 & 9,4 \\
Amostras & $(0,0-129,4)$ & $(0,0-129,4)$ & $(0,0-69,9)$ \\
positivas (\%) & $42,4 \%$ & $81,8 \%$ & $22,7 \%$ \\
\hline
\end{tabular}

Os níveis de Der $p 1$ estão expressos em $\mathrm{pg} / \mathrm{mL}$. Os valores representam a média e, entre parênteses, o mínimo e o máximo de cada grupo. As amostras foram classificadas de acordo com o período de coleta da amostra. 
Um dado interessante que podemos observar na tabela 16, é que amostras coletadas da mesma paciente, porém em períodos diferentes, mantiveram concentrações semelhantes de $\operatorname{Der} p 1$ no leite.

Tabela 16- Concentração de $\operatorname{Der} p 1$ em amostras de leite humano

\begin{tabular}{|c|c|c|c|}
\hline $\begin{array}{c}\text { Identificação da } \\
\text { amostra }\end{array}$ & Data da coleta & $\begin{array}{l}\text { Período de coleta } \\
\text { (após data do parto) }\end{array}$ & $\begin{array}{l}\operatorname{Der} p 1 \\
(\mathrm{pg} / \mathrm{mL})\end{array}$ \\
\hline 1 & 14/09/2008 & 1 semana & 26,29 \\
\hline 2 & 03/03/2008 & 1 semana & 18,5 \\
\hline 3 & $07 / 11 / 2007$ & 1 semana & 19,7 \\
\hline 4 & - & 1 semana & 0 \\
\hline 5 & 26/02/2008 & 1 semana & 21,09 \\
\hline 5 & - & 1 mês & 17,8 \\
\hline 6 & 03/03/2008 & 1 semana & 0 \\
\hline 7 & 09/04/2008 & 1 semana & 26,7 \\
\hline 8 & 09/04/2008 & 1 semana & 21,2 \\
\hline 8 & $17 / 06 / 2009$ & 1 mês & 0 \\
\hline 9 & $30 / 11 / 2007$ & 1 semana & 28,9 \\
\hline 10 & - & 1 mês & 64,6 \\
\hline 10 & - & 2,5 meses & 69,9 \\
\hline 11 & 24/12/2007 & - & 0 \\
\hline 12 & $16 / 06 / 2009$ & 1 mês & 0 \\
\hline 13 & 08/05/2008 & $>1$ semana & 34,5 \\
\hline 14 & 21/05/2008 & $>1$ semana & 0 \\
\hline 15 & 02/05/2008 & $>1$ semana & 0 \\
\hline 16 & 01/04/2008 & $>1$ semana & 21,09 \\
\hline 17 & - & 4 meses & 0 \\
\hline 18 & - & 1-2 meses & 0 \\
\hline 19 & - & 2 meses & 0 \\
\hline 20 & $18 / 01 / 2008$ & 1 semana & 129,4 \\
\hline 21 & - & 1 semana & 59,09 \\
\hline 22 & 22/12/2006 & > 1 semana & 0 \\
\hline 22 & $27 / 01 / 2007$ & $>1$ semana & 0 \\
\hline 22 & 03/07/2009 & $>1$ semana & 0 \\
\hline 22 & $25 / 04 / 2010$ & $>1$ semana & 0 \\
\hline 22 & 29/04/2010 & $>1$ semana & 0 \\
\hline 22 & $22 / 06 / 2010$ & $>1$ semana & 0 \\
\hline 22 & $26 / 06 / 2010$ & $>1$ semana & 0 \\
\hline 22 & 08/07/2010 & > 1 semana & 0 \\
\hline 22 & $16 / 06 / 2010$ & $>1$ semana & 0 \\
\hline
\end{tabular}

- dado não informado 
De acordo com o recente International Study of Asthma and Allergies in Childhood (2011), estima-se que 300 milhões de pessoas, destas $2 / 3$ crianças, sofrem com as alergias respiratorias. $O$ desenvolvimento da sensibilização alérgica e consequentemente as doenças ligadas a ela (asma, rinite e eczema) é resultado da combinação de fatores genéticos e fatores ambientais. Os fatores genéticos abrangem a desregulação na produção de citocinas com maior tendência para o perfil Th2 e/ou deficiência na atividade Th1 (Tulic et al., 2011). Fatores ambientais incluem infecções e exposição aos alérgenos, que interferem na alergia de acordo com a dose e idade na qual o indivíduo é exposto.

Embora os fatores genéticos destas doenças estejam sendo investigados, manipular os fatores de risco já conhecidos acaba sendo a abordagem viável na prevenção da alergia. A mais recomendada entre elas é a não exposição ao alérgeno. No entanto, enquanto que a redução na exposição aos alérgenos é eficaz no combate a manifestação alérgica em indivíduos já sensibilizados, não há evidencias suficientes de que a não exposição durante gestação e período de lactação sejam eficazes na prevenção da "marcha alérgica" na criança.

Neste contexto, os estudos em humanos são escassos e os resultados ainda controversos. Muito se investiga em relação aos alérgenos alimentares e sua passagem pela placenta e leite materno, mas pouco se sabe em relação aos alérgenos ambientais. $O$ presente estudo foi o primeiro a demonstrar e caracterizar a transferência materna de Der $p 1$ e Blo $t 5$ em amostras pareadas de colostro e cordão umbilical e identificar a atopia materna como fator crítico para o aumento de IgG específica nestes compartimentos. Até onde sabemos, também foi o primeiro trabalho a identificar e descrever a presença de alérgenos ambientais e sua IgG específica no colostro e leite humano.

Verificamos que $100 \%$ das amostras de cordão umbilical analisadas apresentaram níveis detectáveis de $\lg G$ anti-Der $p$ e $\lg G$ anti-Blo $t$. Estudos prévios investigaram a presença de IgG específica a outros aero-alérgenos (Bet $v 1$, Fel $d 1$ e Der $f$ 1) no cordão umbilical, mas nem todas as amostras foram positivas (Jenmalm et al., 1997; Platts-Mills et al., 2003; Prescott et al., 2000). A diferença na porcentagem de amostras positivas entre o nosso trabalho e os estudos anteriores provavelmente reflete diferenças na imunogenicidade dos alérgenos testados, assim como na forma de exposição materna ao alérgeno. Em nosso caso, tanto Der $p$ como Blo $t$ são ácaros presentes em altas concentrações na poeira domiciliar e 
facilmente encontrados na região onde as amostras foram coletadas (Binotti et al., 2003, 2005; Oliveira et al., 1999; Pereira et al., 2005).

A IgG específica detectada no cordão umbilical pode ser de origem materna, resultado da transferência de anticorpos pela placenta, ou de origem fetal, como resultado da sensibilização in útero. Nossos resultados mostram forte correlação entre a lgG, lgG1, IgG2, lgG3 e lgG4 específicas para ambos os ácaros no cordão umbilical e soro materno. Além disso, verificamos por imunoblot o padrão de reatividade dos anticorpos frente a ambos extratos de ácaros e verificamos padrões de reconhecimento único entre os indivíduos, sendo idênticos nas amostras pareadas de soro materno e cordão umbilical (ANEXO E). A forte correlação observada, juntamente com o resultado de imunoblot, indicam claramente que a IgG anti-Der $p$ e anti-Blo $t$ presente no cordão umbilical é proveniente do soro materno e resultado da passagem transplacentária de anticorpos.

Uma vez constatada a presença de anticorpos maternos IgG-específicos aos ácaros Der $p$ e Blo $t$ no cordão umbilical, avaliamos a eficiência da passagem transplacentária. Verificamos que a taxa de passagem transplacentária variou entre as diferentes subclasse de lgG, sendo maior para a lgG1, tanto anti-Der $p$ como antiBlo t. A eficiência no transporte da IgG está diretamente reacionada à capacidade de ligação de sua porção Fc ao receptor FcRN (Palmeira et al., 2012). Assim, pequenas diferenças nas sequencias de aminoácidos na região constante das cadeias pesadas explicam a preferência que uma ou outra subclasse tem em atravessar a barreira placentária. De acordo com nossa observação, estudos in vivo e in vitro mostram que o FcRN tem alta afinidade para IgG1 e por essa razão ela é transmitida com maior eficiência quando comparada às outras subclasses (Simister, 2003).

Ainda em relação à passagem transplacentária, uma observação muito interessante foi a queda na eficiência do transporte da $\lg G$ e das subclasses $\lg G 1$, lgG2 e IgG4 à medida que a concentração de anticorpos maternos aumenta. Este dado indica que a transferência de lgG é mediada por um receptor saturável, ou seja, a quantidade de IgG transmitida depende do número de receptores expressos e da taxa de ligação e de liberação de moléculas de lgG desses receptores. De fato, as moléculas de $\lg G$ que não se ligarem aos receptores FcRNs sofrem degradação lisossomal dentro das vesículas no sinciciotrofoblasto (Roopenian et al., 2007). Consequentemente, quando a concentração de $\operatorname{lgG}$ materna é baixa o transporte via 
FcRN é ativo, mas em altas concentrações (geralmente acima de $15 \mathrm{~g} / \mathrm{L}$ ) a concentração de IgG no recém-nascido tende a ser mais baixa que a concentração de sua respectiva mãe (Moraes Pinto et al., 2001). Essa observação foi descrita em diversos trabalhos realizados com populações Africanas, onde as mulheres frequentemente apresentam altas concentrações séricas de $\lg G$, e portanto baixa taxa de passagem transplacentária (Palmeira et al., 2012). A baixa concentração de IgG3 anti-Der $p$ no soro materno, juntamente com a alta afinidade desta subclasse ao receptor FcRN, provavelmente explica porque não observamos queda na taxa de passagem transplacentária em relação ao nível de anticorpos maternos.

Por fim, alguns estudos sugerem que a passagem de anticorpos através da placenta pode não depender somente de sua porção $\mathrm{Fc}$, pois a especificidade antigênica do anticorpo parece também ser importante. Em gestantes com altos níveis de anticorpos contra influenza $A 2$, herpes simplex, tétano, estreptolisina $O, S$. pneumoniae ou polissacáride polirribosil-ribitol fosfato (PRP), somente esses anticorpos foram transmitidos numa taxa mais baixa aos fetos; os outros anticorpos apresentaram eficiência semelhante ao do grupo controle (Moraes Pinto et al., 2001). Apesar de ainda não sabermos o mecanismo responsável por tal fenômeno, essa observação pode explicar a diferença no padrão de transferência das Igs específicas entre Der p e Blo $t$.

Uma vez caracterizada a passagem transplacentária, avaliamos a influência do estado atópico materno na concentração dos anticorpos transferidos. Observamos que a lgG específica aos ácaros Der $p$ e Blo t está presente em maior concentração no cordão umbilical de neonatos de mães atópicas quando comparadas aos de mães não atópicas. A literatura aponta que pacientes asmáticos e/ou com rinite alérgica apresentam níveis elevados de $\lg G$ alérgeno específica quando comparados a indivíduos não sensibilizados (Aydogan, 2007; Okahata et al., 1990; Rizzo et al., 1993; Stewart et al., 1988). Assim, a concentração de lgG observada no cordão umbilical, reflete os altos níveis de anticorpos específicos também observados no soro de mães atópicas. Altos níveis de lgG em pacientes atópicos pode ser explicado pela indução eficiente na síntese de anticorpos nas respostas tipo Th2. Outra possível explicação seria a maior exposição aos alérgenos da poeira por mães atópicas quando comparadas às não atópicas. Embora não tenhamos medido a concentração de alérgeno nas casas das pacientes, acreditamos que a exposição materna não seja a responsável pelo aumento 
observado, uma vez que todas as pacientes do estudo habitam em uma mesma região, onde estes ácaros estão distribuídos de forma homogênea (de Oliveira et al., 2003).

Em relação às subclasses, maior concentração de lgG4 específica em pacientes atópicos é comumente observada, enquanto que os níveis de lgG1 geralmente são similares (Jarvis et al., 2007; Pereira et al., 2005). Em nosso estudo também observamos maior concentração de lgG4 específica ao Der p e Blo $t$ no cordão umbilical de neonatos de mães atópicas comparada as não atópicas e níveis similares de lgG1. A maior concentração de lgG4 pode ser explicada pelo fato de que esta é induzida pelas mesmas citocinas indutoras da síntese de lgE; IL-4 e IL-13 (Aalberse et al., 2009).

A IgG3-anti-Blo $t$ e IgG2 anti-Der $p$ também estavam em maiores concentrações no grupo de mães atópicas. A diferença observada entre o padrão de resposta induzida pelo ácaro Der $p$ em comparação ao Blo $t$ indica que as proteínas que constituem cada ácaro apresentam propriedades imunogênicas particulares. De acordo, já foi demonstrado em modelo murino que a resposta inflamatória pulmonar induzida pela sensibilização ao Der $p$ ou Blo $t$ apresenta característica distinta em relação ao recrutamento de células inflamatórias (Carvalho et al., 2004). De fato, apesar de os alérgenos de ambos os ácaros estarem agrupados nas mesmas famílias, para $67 \%$ dos alérgenos de Blo $t$ a ligação da lgE é espécie-específica, ou seja, não é inibida pelas proteínas presentes no Der p (Arruda et al.,1997; Tsai et al., 1998). Outras hipóteses para explicar a diferença no padrão de resposta entre Der $p$ e Blo $t$ incluem (1) diferenças na forma e concentração de exposição aos ácaros (2) diferença na preparação dos extratos comerciais e consequentemente na concentração dos componentes associados aos ácaros, como nível de endo e exoquitina e/ou LPS.

Mas qual importância da transferência de anticorpos alérgenos específicos para o recém-nascido? Estudos em modelo animal demonstraram que a transferência materna de anticorpos lgG alérgeno-específica inibe a resposta alérgica nos descendentes (Boyle et al., 2006; Fusaro et al., 2002, 2007; Jarret et al., 1983; Melkild et al., 2002; Polt et al., 2008; Seeger et al., 1998; Uthof et al., 2003; Victor et al., 2010). Estudos longitudinais em humanos também sugerem papel imunorregulador da transferência in útero de anticorpos IgG alérgenos específicos. Dannaeus et al. (1978) demonstraram que altos níveis de lgG específica para 
proteínas do leite e ovo no cordão umbilical protege a criança contra o desenvolvimento de atopia nos primeiros 2 anos de vida. Já os autores Jenmalm, Bjorkstén demonstraram que altas concentrações de $\lg G$ específica a alérgenos ambientais, mas não aos alérgenos alimentares no cordão umbilical estavam associados a um menor índice de desenvolvimento de atopia até os 8 anos de idade (Jenmalm, Bjorkstén, 2000).

O estudo de Glovsky e colaboradores analisou o efeito da imunoterapia específica durante a gestação e posterior sensibilização alérgica na criança (Glovsky et al., 1991). Os resultados sugerem que anticorpos lgG4 bloqueadores induzidos na imunoterapia são transferidos pela placenta e responsáveis pela diminuição na sensibilização alérgica nas crianças. Esta observação é importante visto que em nosso estudo observamos que mães atópicas transferem via passagem transplacentária maiores concentrações de lgG4 específica. Embora não possamos confirmar o papel imunorregulatório da IgG4 materna no recém-nascido, ele já foi demonstrado em outros estudos (Frew et al., 2010; Ruiter et al., 2007) e pode ser atribuído à algumas característica peculiares que esta subclasse apresenta: A lgG4 é capaz de neutralizar o antígeno ou bloquear a lgE induzindo menos inflamação que as outras subclasses, pois age como uma molécula monovalente, tem capacidade reduzida de ligação aos receptores da superfície celular e não ativa a cascata do complemento (Aalberse et al., 2009).

Além dos anticorpos específicos, nosso estudo mostrou que alérgenos inalados pela mãe podem de fato atravessar a barreira placentária. Embora os mecanismos que permitem este transporte ainda precisem ser esclarecidos, sabemos que o transporte ativo da IgG materna pela placenta oferece um veículo ideal para o transferência de alérgenos ao feto. Holloway et al. (2000) demonstraram que a concentração de Der $p 1$ no cordão umbilical foi maior que a presente no respectivo soro materno, indicando a existência de um transporte ativo. Além disso, já foi demonstrado em modelo in vitro de perfusão da placenta que a passagem transplacentária dos alérgenos Bet v1 e $\beta$-lactoglobulina é mais eficiente na presença de lgG específica (Szepfalusi et al., 2000). Em humanos, imunecomplexos-lgG ao alérgeno do gato $F e l d 1$ no cordão umbilical já foi demonstrado (Casas, 2001).

Em nosso estudo, não podemos afirmar se os alérgenos detectados no cordão umbilical estão em sua forma livre ou em imunecomplexos. Diversas 
tentativas para quantificação e dissociação dos possíveis imunecomplexos foram realizadas, mas a reação cruzada entre os anticorpos associado a outros problemas metodológicos impediu tal investigação. No entanto, a presença de ambos, o alérgeno e sua lgG específica, nos faz acreditar que a formação de imunecomplexos é viável e pode ser responsável pela transferência de uma porção dos antígenos presentes no cordão umbilical. Diferenças individuais que alterem a permeabilidade da placenta a macromoléculas (como o deposito de fibrina comumente observada em todas as gestações) também podem influenciar a concentração de alérgeno transportado, principalmente em sua forma livre (Kaufmann et al., 1996). Essa observação explica a correlação entre a concentração de Der $p 1$ e Blo $t 5$ no cordão umbilical, independente dos níveis de anticorpos e sensibilização materna.

Já foi demonstrado que o alérgeno Der $p 1$ também pode ser detectado no liquido amniótico. Ou seja, além de atravessar a barreira placentária ele é capaz de passar pela membrana amniótica e ser detectado na circulação fetal e líquido amniótico, respectivamente (Holloway et al., 2000; Szepfalusi et al., 2006). Assim, como o feto respira e ingere grandes quantidades do líquido amniótico, alérgenos adquiridos durante a gestação podem estimular a imunidade do recém-nascido de forma sistêmica e em nível de mucosa, nos tecidos linfóides associado à mucosa gastrintestinal e respiratória (Holloway et al., 2000).

Com aproximadamente 22 semanas de gestação o feto já é capaz de responder de maneira específica eventuais alérgenos que entrar em contato (Jenmalm et al., 2000; Jones et al., 2002), sustentando a idéia de que a sensibilização pode ocorrer previamente intra-útero (Devereux et al., 2001). A presença de IgM específica em $100 \%$ das amostras de cordão umbilical confirma esta hipótese e demonstra que, embora algumas amostras apresentem níveis indetectáveis de Der $p 1$ e Blo $t 5$ no cordão umbilical, virtualmente todos os recémnascidos entraram em contato com estas ou outras proteínas presentes nos extratos dos ácaros durante o período fetal. Reações cruzadas também podem explicar a alta porcentagem observada. Como exemplo, mães que não estiveram grávidas durante a "estação de pólen" apresentam filhos com resposta imune específica a estes alérgenos (Jones et al., 2002), assim como resposta de células mononucleares do cordão umbilical ao toxóide tetânico e difteria, sem exposição materna aparente a estes antígenos durante a gestação (Prescott, 2003). 
No entanto, ainda não há estudo que mostre relação convincente entre os níveis de exposição fetal aos alérgenos com a magnitude ou perfil da resposta imunológica específica no recém-nascido (Chan-Yeung et al., 1999; Edelbauer et al., 2004; Hagendorens et al., 2004; Marks et al., 2002; Miller et al., 2001; Smillie et al., 2001). Embora que a redução na exposição a alérgenos ambientais seja uma forma eficaz de prevenir a manifestação alérgica em crianças sensibilizadas, não há evidências de que a própria sensibilização também seja reduzida; podendo de fato aumentar em algumas circunstâncias. Essa observação aplica-se para alergia ao amendoim, que quando evitado durante a gestação e primeiros anos de vida ao invés de proteger contra sensibilização aumenta o risco em desenvolvê-la (Turcanu et al., 2003). O encontro com o alérgeno no período fetal e na ausência de inflamação ou outros sinais que possam induzir a maturação das células dendríticas, pode induzir preferencialmente a tolerância que a ativação (Thorton et al., 2002).

A passagem transplacentária não é o único fator responsável pela influência materna no perfil de resposta imune da criança. Depois do nascimento, a amamentação mantém forte interação entre a mãe e a criança e particularmente permite que a lg materna seja continuamente transferida.

Uma vez que a maioria dos antígenos inalados é encaminhada ao intestino (Holt et al., 1981), a presença de IgA alérgeno específica no colostro pode proteger a mucosa intestinal e proteger a criança contra alergias respiratórias assim como proposto para as alergias alimentares. Evidências epidemiológicas de que a $\lg A$ previne a manifestação alérgica no lactente (Calbi et al., 1998; Janzi et al., 2009; Savilahti et al.,1991, 2005) pode ser explicada pelo fato de a IgA eliminar o antígeno sem induzir inflamação e ainda exercer efeitos imunorregulatórios (Favre et al., 2005; Pilett et al.,2004; Sletten et al., 2007; Smits et al., 2009). Surpreendentemente, encontramos $\lg \mathrm{A}$ anti-Der $p$ e $\lg \mathrm{A}$ anti-Blo $t$ em todas as amostras de colostro testadas.

Os valores de $\lg A$ total e específica foram variados entre as amostras e sem diferença significativa entre as mães atópicas e não atópicas. Um estudo prévio quantificou a presença de IgA específica ao alérgeno do gato no colostro de mães atópicas e não atópicas e também não observou diferença (Casas et al., 2000). A ausência do efeito da atopia nos níveis de $\lg A$ no colostro pode ser explicado pelo fato de que o swith de classe para IgA depende principalmente da presença de TGF$\beta$ (van Vlasselaer et al., 1992). De acordo com esta observação, encontramos níveis 
similares de TGF- $\beta$ no colostro de mães atópicas e não atópicas e observamos que os níveis de ambas, IgA total e IgA específica, correlacionam-se com os níveis de TGF- $\beta$ no colostro.

Além da $\lg A$, nosso estudo demonstrou pela primeira vez a presença $\lg G$ específica a alérgenos ambientais no colostro humano. Assim como para IgG sérica, maiores concentrações de lgG específica a ambos os ácaros no colostro de mães atópicas quando comparada às não atópicas pode ser explicada pela resposta imune humoral geralmente aumentada nestes pacientes. A IgG presente no colostro pode ser sintetizada localmente na glândula mamária (Hurley, 2003) ou proveniente do soro materno, baseado na observação de que a reposição intravenosa de lg em mães imunodeficientes resultou na presença de lgG no leite materno (Palmeira et al., 2009). O primeiro mecanismo pode operar no grupo de mães atópicas, uma vez que somente neste grupo não há correlação entre os níveis de IgG em amostras pareadas de colostro e soro materno.

Também demonstramos pela primeira vez a presença de alérgenos ambientais no colostro e leite materno. O fato de observarmos correlação entre os níveis de Der $p$ e Blo $t$ no colostro, indica que algumas mães apresentam predisposição em transportar maiores concentrações de proteínas exógenas para o leite materno. De acordo com essa observação verificamos que amostras de leite de uma mesma mãe, porém coletadas em períodos diferentes, tendem a apresentar mesma concentração de Der $p 1$ no colostro.

Embora ainda não demonstrado, podemos assumir que existem duas rotas possíveis que permite que as proteínas presentes no soro materno sejam transferidas à glândula mamária: a paracelular e a transcelular. A primeira é dependente da permeabilidade da glândula mamária e a segunda dependente da presença de imunecomplexos e mediada pelo receptor FcRN expresso nas células epiteliais da glândula mamaria (Denis, 2012).

O fato de observarmos maior concentração de Blo $t 5$ (14 kDa) em relação ao Der p 1 (25 kDa), indica que o transporte paracelular é responsável por parte dos alérgenos detectados no colostro e que a eficiência do mesmo é influenciado pelo tamanho da proteína transportada. Já foi demonstrado que as junções compactas localizadas entre as células epiteliais da glândula mamária são "frouxas" no préparto e começam a se fechar após 1-2 dias do pós-parto. Em consequência, a permeabilidade da glândula mamária diminui (Benn et al., 2004). Nossos resultados 
suportam essa observação uma vez que a concentração de Der $p 1$ foi maior no colostro> leite primeira semana > leite com mais de uma semana. Estudo que comparou a concentração de gliadina no leite e colostro também demonstrou que estava presente em maiores concentrações no colostro (Chirdo et al., 1998).

Embora alguns estudos demonstrem que a permeabilidade epitelial está aumentada em paciente atópicos (Jackson et al., 1981), a análise da taxa de sódiopotássio no leite e colostro mostrou que a permeabilidade da glândula mamária de mães atópicas e não atópicas é semelhante (Benn et al., 2004). De fato, não observamos diferença na concentração de Blo $t 5$ entre as mães atópicas e não atópicas.

Já a maior concentração de Der $p 1$ nas mães atópicas pode estar relacionada ao fato deste alérgeno depender da via transcelular para alcançar a glândula mamária, pois apresenta maior peso molecular quando comparado ao Blo $t$ 5. A correlação observada entre os níveis de IgG sérica materna e a concentração de Der $p 1$ no colostro suporta essa hipótese. Assim, a maior concentração de Der $p$ 1 no colostro de mães atópicas pode estar relacionado ao fato destas mães apresentarem maior concentração de $\lg G$ especifica no soro. Apesar de não podermos afirmar a presença de imunecomplexos IgG-Der $p 1$ em nossas amostras, tais imunecomplexos já foram identificados no soro tanto de pacientes alérgicos como sadios (Casas et al., 2001; Haddad et al.,1983; Husby et al.,1985).

Nossos dados indicam que a capacidade de transporte de alérgenos para 0 leite é independente do transporte para o cordão umbilical, mas parece ser mais eficaz no primeiro. De acordo com nossos achados, Vance e colaboradores também encontraram maior concentração de ovalbumina no leite $(0.12-1258 \mathrm{ng} / \mathrm{mL})$ quando comparada a amostras pareadas de cordão umbilical $(0.05-5.67 \mathrm{ng} / \mathrm{mL}$ ) (Vance et al., 2005).

Recentemente, o grupo da pesquisadora Verhasselt demonstrou em modelo animal que a transferência de antígeno via leite materno protege a prole contra alergia respiratória de maneira específica (Verhasselt et al., 2008). Neste modelo, a amamentação protege a prole contra alergia, pois os critérios para indução de tolerância são obedecidos: administração do antígeno via oral em ambiente tolerogênico. Neste caso além dos fatores tolerogênicos presentes no leite como TGF- $\beta$, imunecomplexos alérgeno-lgG permitem melhor transferência do alérgenos 
via receptor FcRN através da barreira intestinal do neonato, comparado aos não complexados (Mosconi et al., 2010).

Hipoteticamente, a IgG específica no leite humano pode desencadear função similar, pois o receptor FcRN também está expresso nas células epiteliais do intestino da criança. Portanto, diferente da $\lg A$ que fica retida no lúmen intestinal, imunecomplexos-lgG presentes no colostro podem ser transportados via trancitose para a lâmina própria do recém-nascido e desencadear a resposta imunorregulatória observada em modelo animal (Israel et al., 1997; Roopenian et al., 2007). Esta fonte contínua após o nascimento pode ser suficiente para manter os níveis sistêmicos no recém-nascido e permitir a proteção de asma quando a lgG transferida via passagem transplacentária já estiver sido degradada.

Em um primeiro momento o papel de imunecomplexos na indução de tolerância pode parecer contraditório, uma vez que classicamente os imunecomplexos estão envolvidos em reações inflamatórias severas e dano tecidual, como em pacientes com lúpus eritematoso ou glomerulonefrite pósestreptocócica. No entanto, em outros "cenários" os imunecomplexos podem suprimir a resposta imunológica. Tal observação já foi demonstrada em modelo animal (Caulfield, Shaffer, 1987; da Costa et al., 1990; Sinclair et al., 1974) e humanos (Machiels et al., 1990, 1993). Há alguns anos atrás, Saint-Remy et al., demonstraram que pacientes que sofrem de asma alérgica ao ácaro Dermatophagoides podem ser eficientemente tratados por inoculação de imunecomplexos IgG-alérgeno (Machiels et al., 1990).

Ainda de acordo com a hipótese de que a IgG presente no leite materno pode colaborar na proteção contra alergia, estudos recentes apontam o leite como importante forma de profilaxia contra alergias principalmente em crianças com histórico familiar positivo a atopia. Um artigo de revisão de estudos multidisciplinares sobre amamentação analisou 56 publicações entre 1966 e 2001 e verificou que mais da metade mostraram que a amamentação é eficaz na proteção contra dermatite atópica e asma, principalmente em crianças com histórico familiar de atopia (Van Odijk et al., 2003). Outro artigo de meta-análise de estudos prospectivos também concluiu que a proteção do leite materno é maior no grupo de crianças com histórico familiar de asma ou sensibilização alérgica (Gdalevich et al., 2001). Por outro lado, dois outros estudos prospectivos em coortes de 4089 (Kull, 2004) e 3115 crianças (Scholtens et al., 2001) respectivamente, não observaram aumento na proteção no 
caso de hereditariedade para alergia. Além disso, outro estudo prospectivo que analisou 1200 crianças verificou que a amamentação não protegeu contra a asma alérgica aos nove anos de idade, podendo ainda aumentar o risco em desenvolver asma em crianças com histórico familiar da doença (Sears et al., 2002). Neste estudo compararam crianças amamentadas por $>4$ semanas e $<4$ semanas, mas 0 tempo de amamentação foi registrado de forma retrospectiva, apenas quando a criança completou 3 anos de idade. Similar à ele, um estudo randomizado que recrutou mais 17.046 pares de mãe-criança e acompanhou 81,5\% dessas crianças até os 6,5 anos de idade, não confirmou efeito protetor da amamentação na prevenção da asma (Kramer et al., 2007).

De forma geral, todos estes dados dificilmente podem ser comparados em relação ao protocolo experimental, critério de análise, seleção da população, assim como a qualidade e duração da amamentação, pois por natureza a decisão em amamentar nunca é randomizada. É importante ressaltar que nem a exposição materna aos alérgenos e tão pouco a presença destes fatores no leite materno foram levados em consideração nestes trabalhos, podendo explicar parte da controvérsia observada entre eles.

Acredito no potencial tolerogênico que o leite materno possui e fornece à criança e pretendo seguir com essa investigação, cujo principal objetivo será identificar os possíveis fatores protetores contra a alergia e os parâmetros que condicionam sua presença no leite humano. Estudos clínicos para verificar se a transferência destes alérgenos, na presença ou não de anticorpos específicos, pode conferir proteção contra alergia nas crianças amamentadas já estão em andamento. O presente trabalho representou o primeiro passo para tal investigação que será de extrema importância para o esclarecimento e direcionamento das práticas de amamentação em relação à proteção alérgica. 
6 CONCLUSÃO 
- Alérgenos ambientais estão presentes no cordão umbilical e colostro e, portanto, podem ser transferidos à criança durante o período fetal e de amamentação; respectivamente. Dentre eles:

- o Der $p 1$, principal alérgeno do acaro Dermatophagoides pteronyssinus;

- o Blo t5, principal alérgeno do acaro Blomia tropicalis.

- anticorpos S-IgA específicos aos ácaros Der $p$ e Blo $t$ estão presentes no colostro materno em concentrações bastante variáveis, e sua concentração não apresenta relação com o estado atópico materno;

- a atopia é um fator crítico para o aumento de IgG materna específica ao Der p e $B l o t$, tanto no colostro como no cordão umbilical de seus respectivos recémnascidos. 


\section{REFERÊNCIAS ${ }^{1}$}

Aalberse RC, Stapel SO, Schuurman J, Rispens T. Immunoglobulin G4: an odd antibody. Clin Exp Allergy. 2009 Apr;39:469-77.

Almeida KC, Gennai-Cardoso ML, Cunha-Júnior JP, Ynoue LH, Alves R, Resende RO, Sung SJ, Taketomi EA. Responses of $\operatorname{lgE}, \lg G 1$ and $\lg G 4$ to concavalin Abinding Blomia tropicalis antigens in allergic patients. Bras J Med Biol Res. 2006;39: 1445-54.

Arlian LG, Platts-Mills TAE. The biology of dust mites and the remediation of mite allergens in allergic disease. J Allergy Clin Immunol. 2001;107(3):406-13.

Arruda LK, Rizzo MC, Chapman MD, Fernan-dez-Caldas E, Baggio D. Platts Mills TAE, Naspitz CK. Exposure and sensitization to dust mite allergens among asthmatic children in São Paulo, Brazil. Clin Exp Allergy. 1991;21:433-9.

Arruda LK, Vailes LD, Platts-Mills TA, Fernandez-Caldas E, Montealegre F, Lin KL, Chua KY, Rizzo MC, Naspitz CK, Chapman MDSensitization to Blomia tropicalis in patients with asthma and identification of allergen Blo t 5. Am J Respir Crit Care Med. 1997;155(1):343-50.

Auerbach R, Clark S. Immunological tolerance: transmission from mother to offspring. Science. 1975;189:811-13.

Axelsson I, Jakobsson I, Lindberg T, Benediktsson B. Bovine b-lactoglobulin in the human milk. A longitudinal study during the whole lactation period Acta Paediatr Scand. 1986;75:702-7.

Aydogan M, Mete N, Yazi D, Akkoc T, Ozdemir C, Blaser K, et al. Comparison of Der p1-specific antibody levels in children with allergic airway disease and healthy controls. Pediatr Allergy Immunol. 2007;18:320-5.

Barrett NA, Rahman OM, Fernandez JM et al. Dectin-2 mediates Th2 immunity through the generation of cysteinyl leukotrienes. J. Exp. Med. 2011;208:593-604.

Benlounes N, Chedid R, Thuillier F, Desjeux JF, Rousselet F, Heyman M. Intestinal transport and processing of immunoglobulin $G$ in the neonatal and adult rat. Biol Neonate. 1995;67:254-63.

\footnotetext{
${ }^{1}$ De acordo com: International Committee of Medical journal editors. [Internet]. Uniform requirements for manuscripts submitted to Biomedical Journal:sample references.[updated 2011 Jul 15]. Avaliable from http://www.icmje.org
} 
Benn CS, Böttcher MF, Pedersen BV, Filteau SM, Duche'n K. Mammary epithelial paracellular permeability in atopic and non-atopic mothers versus childhood atopy. Pediatr Allergy Immunol. 2004:15:123-6.

Bensch KG, Dominguez E, Liebow AA. Absorption of intact protein molecules across the pulmonary air-tissue barrier. Science. 1967;157:1204-06.

Bertino E, Prandi GM, Fabris C, et al. Human milk proteins may interfere in ELISA measurements of bovine B-lactoglobulin in human milk. Acta Paediatr. 1996;85:5439.

Binotti RS, Oliveira CH, Santos JC, Binotti CS, Muniz JRO, Prado AP. Survey of acarine in dust samplings of curtains in the city of campinas, Brasil Braz J Biol. 2005; 65(1):25-8.

Binotti RS, Santos JC, Oliveira CH, Condino-Neto A, Prado AP. Characterization of mites in sofa dust samples from homes in Campinas Southeast Brazil. Revista de Ciências Médicas (PUCCAMP). 2003;12:327-30.

Björksten B, Clayton T, Ellwood P, Stewart A, Strachan D, ISAAC Phase III Study Group. Worldwide time trends for symptoms of rhinitis and conjunctivitis: Phase III of the International Study of Asthma and Allergies in Childhood. Pediatr Allergy Immunol. 2008;19:110-24

Bochner BS, Busse WW. Mechanisma of asthma and allergic inflamation. J Allergy Clin Immunol. 2005;115:953-59.

Bonnelykke K, Pipper CB, Bisgaard H. Sensitization does not develop in utero. J Allergy Clin Immunol. 2008 Mar;121:646-51.

Bonnelykke K, Pipper CB, Bisgaard H. Transfer of maternal IgE can be a common cause of increased IgE levels in cord blood. J Allergy Clin Immunol. 2010;126:65763.

Boyle RJ, Tang ML. Can allergic diseases be prevented prenatally? Allergy. 2006;61:1423-31.

Braley JF, Dawson CA, Moore VL, Cozzini BO. Absorption of inhaled antigen into the circulation of isolated lungs from normal and immunized rabbits. J Clin Invest. 1978; 61:1240-6.

Brambell FWR, Hemmings WA, McCarthy EF, Kerkwick RA. The passage into the embryonic yolk-sac cavity of maternal plasma protein in rabbits. J Physiol. 1949;108:177-85.

Brandtzaeg P. Mucosal immunity: induction, dissemination, and effector functions. Scand J Immunol. 2009;70(6):505-15. 
Brandtzaeg P. Food allergy: separating the science from the mythology. Nat Rev Gastroenterol Hepatol. 2010;7(7):380-400.

Brandtzaeg P. Mucosal immunity: integration between mother and the breast-fed infant. Vaccine. 2003;28;21:3382-8.

Brandtzaeg $P$. The secretory immune system of lactating human mammary glands compared with other exocrine organs. Ann N Y Acad Sci. 1983;409:353-81.

Brandtzaeg PE. Current understanding of gastrointestinal immunoregulation and its relation to food allergy. Ann N Y Acad Sci. 2002;964:13-45.

Bronswijk $\mathrm{J}$ van. House dust biology for allergist, ácarologist and mycologists. Zoelmond: JEMH; 1981

Calbi M, Giacchetti L. Low breast milk IgA and high blood eosinophil count in breastfed newborns determine higher risk for developing atopic eczema after an 18-month follow-up. J Investig Allergol Clin Immunol. 1998;8:161-4.

Cant A, Marsden RA, Kilshaw PJ. Egg and cows' milk hypersensitivity in exclusively breast fed infants with eczema, and detection of egg protein in breast milk. Br Med J 1985;291:932-5.

Carvalho AF, Fusaro AE, Oliveira CR, Brito CA, Duarte AJ, Sato MN. Blomia tropicalis and Dermatophagoides pteronyssinus mites evoke distinct patterns of airway cellular influx in type I hypersensitivity murine model. J Clin Immunol. 2004; 24(5):533-41.

Casas R, Björkstèn B, Detection of Fe d 1-immunoglobulin G immune complexes in cord blood and sera from allergic and non-allergic mothers. Pediatr Allergy Immunol. 2001;12:59-64.

Casas R, Bottcher MF, Duchen K, Bjorksten B. Detection of IgA antibodies to cat, beta-lactoglobulin, and ovalbumin allergens in human milk. J Allergy Clin Immunol. 2000;105:1236-40.

Caulfield MJ, Shaffer D. Immunoregulation by antigen/antibody complexes. I. Specific immunosuppression induced in vivo with immune complexes formed in antibody excess. J Immunol. 1987;138(11):3680-3.

Cavagni G, Paganelli R, Caffarelli C, et al. Passage of food antigens into circulation of breast-fed infants with atopic dermatitis. Ann Allergy. 1988;61:361-5.

Chan-Yeung M, McClean PA, Sandell PR, Slutsky AS, Zamel N. Sensitization to cat without direct exposure to cats. Clin Exp Allergy. 1999;29(6):725-8. 
Chew FT, YI FC, Chua KY, Fernandez-Caldas E, Arruda LK, Chapman MD, Lee BW. Allergenic differences between the domestic mites Blomia tropicalis and Dermatophagoides pteronyssinus. Clin Exp Allergy. 1999;29:982-8.

Chirdo FG, Rumbo M, Anon MC, Fossati CA. Presence of high levels of nondegraded gliadin in breast milk from healthy mothers. Scand $J$ Gastroenterol 1998;33:1186-92.

Comoy EE, Pestel J, Duez C, Stewart GA, Vendeville C, et al, The house dust mite allergens, Dermatophagoide pteronissinus, promotes type 2 response by modulating the balance between IL-4 and IFN-Y. J Immunol. 1998;160:2456-62.

Corthésy B. Role of secretory immunoglobulin A and secretory component in the protection of mucosal surfaces. Future Microbiology. 2010;5,817-29.

Corver K, Kerkhof M, Brussee JE, Brunekreef B, van Strien RT, Vos AP, Smit HA, Gerritsen J, Neijens HJ, de Jongste JC. House dust mite allergen reduction and allergy at 4 yr: follow up of the PIAMA-study. Pediatr Allergy Immunol. 2006;17(5):329-36.

Costa-Carvalho T, Vieira HM, Dimantas RB et al. Transfer of IgG subclasses across placenta in term and preterm newborns. Braz J Med Biol Res. 1996;29(2):201-4.

da Costa PS, de Macedo MS, Perini A. Suppresion of mouse IGE response by immune complexes. J Allergy Clin Immunol. 1990;86(4 Pt 1):496-502.

Dannaeus A, Johannson SGO, Fourcard T. Clinical and immunological aspects of food allergy. II. Development of Allergic symptoms and humoral immune response to foods in infants of atopic mothers during the first 24 months of life. Acta Paed Scand. 1978;67(4):497-504.

de Oliveira CH, Binotti RS, Muniz JR, dos Santos JC, do Prado AP, de Pinho AJ, Jr. Comparison of house dust mites found on different mattress surfaces. Ann Allergy Asthma Immunol. 2003 Dec;91:559-62.

Denis M, Loras-Duclaux I, Lachaux A. Cow's milk protein allergy through human milk. Arch Pédiatr. 2012;19:305-12

Deverelux G, Seaton A, Barber RN. In utero priming of allergen-specific helper Tcells. Clin Exp Allergy. 2001;31:1686-95.

Duchén $\mathrm{K}$, Casas R, Fageras-Böttcher $\mathrm{M}, \mathrm{Yu}$ G, Björkstén B. Human milk polynsaturated long-chain fatty acids and secretory immunoglobulin $A$ antibodies and early childhood allergy. Pediatr Allergy immunol. 2000;11:29-39.

Edenharter G, Bergmann RL, Bergmann KE et al. Cord blood-lgE as risk factor and predictor for atopic diseases. Clin Exp Allergy. 1998;28:671-8. 
Faria AM, Weiner HL. Oral tolerance. Immunol Rev. 2005;206:232-59.

Favre L, Spertini F, Corthesy B. Secretory IgA possesses intrinsic modulatory properties stimulating mucosal and systemic immune responses. J Immunol. 2005 Sep 1;175:2793-800.

Favre L, Spertini F, Corthesy B. Secretory IgA possesses intrinsic modulatory properties stimulating mucosal and systemic immune responses. J Immunol. 2005;175(1):2793-800.

Fernández-Caldas E, Puerta L, Mercado D, Lockey RF, Caraballo LR. Mite fauna, Der $\mathrm{p} \mathrm{I}$, Der $\mathrm{f} I$ and Blomia tropicalis allergen levels in a tropical environment. Clin Exp Allergy. 1993; 23(4):292-7.

Forastiere F, Sunyer J, Farchi S, Corbo G, Pistelli R, Baldacci S, Simo,i M, Agabiti N, Perucc CA, Viegi G. Number of offspring and maternal allergy. Allergy. 2005; 60:510-14.

Frew AJ. Allergen immunotherapy. J Allergy Clin Immunol. 2010;125:S306-13.

Fukushima Y, Kawata Y, Onda T, Kitagawa M. Consumption of cow milk and egg by lactating women and the presence of b-lactoglobulin and ovalbumin in breast milk. Am J Clin Nutr. 1997;65:30-5.

Fukushima Y, Kawata Y, Onda T, Kitagawa M. Consumption of cow milk and egg by lactating women and the presence of beta-lactoglobulin and ovalbumin in breast milk. Am J Clin Nutr. 1997;65:30-5.

Fusaro AE, Brito CA, Victor JR et al. Maternal-fetal interaction: preconception immunization in mice prevents neonatal sensitization induced by allergen exposure during pregnancy and breastfeeding. Immunology. 2007;122:107-15.

Fusaro AE, Maciel M, Victor JR, Oliveira CR, Duarte AJ, Sato MN. Influence of maternal murine immunization with Dermatophagoides pteronyssinus extract on the type I hypersensitivity response in offspring. Int Arch Allergy Immunol. 2002;127:20816.

Galbi M, Giacchetti L. Low breast milk IgA and high blood eosinophil count in breastfed newborns determine higher risk for developing atopic eczema after an 18-month follow-up. J Investig Allergol Clin Immunol. 1998;8:161-4.

Gdalevich M, Mimouni D, Mimouni M. Breast-feeding and the risk of bronchial asthma in childhood: a systematic review with meta-analysis of prospective studies. $J$ Pediatr. 2001;139:261-6.

Geller M. Alergia aos ácaros no Rio de Janeiro: análise prospectiva em 700 pacientes com asma e (ou) rinite. J Bras Med. 1996,71:164-70 
Gendrel D, Richard-Lenoble D, Massamba MB, Picaud A, Moreno JL. Transfert placentaire des anticorps antitétaniques et protection du nouveau-né. Arch $\mathrm{Fr}$ Pediatr. 1990;47:725-9.

Georas, SN, Guo JFU, Casolaro V. T-helper cell type-2 regulation in allergic disease. Eur Respir J. 2005;26:1119-37.

Glovsky MM, Ghekiere L, Rejzek E. Effect of maternal immunotherapy on immediate skin test reactivity, specific rye I IgG and IgE antibody, and total $\lg E$ of the children. Ann Allergy. 1991;67:21-4.

Gondo A, Saeki N, Tokuda Y. IgG4 antibodies in patients with atopic dermatitis. Br J Dermatol. 1987;117(3):301-10

Gould HJ, Sutton BJ. IgE in allergy and asthma today. Nat Rev Immunol. 2008;8:205-17.

Greer FR, Sicherer SH, Burks AW. Effects of early nutritional interventions on the development of atopic disease in infants and children: the role of maternal dietary restriction, breastfeeding, timing of introduction of complementary foods, and hydrolyzed formulas. Pediatrics. 2008;121:183-91.

Gregory LG, Lloyd CM. Orchestrating house dust mite-associated allergy in the lung. Trends Immunol. 2011;32(9):402-11

Haddad ZH, Vetter M, Friedmann J, Sainz C, Brunner E. Detection and kinetics of antigen-specific $\lg E$ and $\lg G$ immune complexes in food allergy. Ann Allergy. 1983; $51: 255$.

Hagendorens MM, Ebo DG, Bridts CH, Van de Water L, De Clerck LS, Stevens WJ. Prenatal exposure to house dust mite allergen (Der $p$ 1), cord blood T cell phenotype and cytokine production and atopic dermatitis during the first year of life. Pediatr Allergy Immunol. 2004;15:308- 15.

Hammad H, Chieppa M, Perros F, et al. House dust mite allergen induces asthma via Toll-like receptor 4 triggering of airway structural cells. Nat. Med. 2009;15,410-6.

Hansen LG, Halken S, Host A, Moller K, Osterballe O. Prediction of allergy from family history and cord blood lgE levels. A follow-up at the age of 5 years. Cord blood IgE. IV. Pediatr Allergy Immunol. 1993;4:34-40.

Hanson LA. Session 1: Feeding and infant development breast-feeding and immune function. The Proceedings of the Nutrition Society. 2007;66:384-96.

Hay DB, Hart BJ, Pearce RB, Kozakiewicz Z, Douglas AE. How relevant are house dust mite-fungal interactions in laboratory culture to the natural dust system? Exp. Appl. Acarol. 1992;16:37-47. 
Chong Neto HJ, Rosário NA, Solé D; Latin American ISAAC Group. Asthma and Rhinitis in South America: How Different They are From Other Parts of the World. Allergy Asthma Immunol Res. 2012;4(2):62-7

Hertz-Picciotto I, Park HY, Dostal M, Kocan A, Trnovec T, Sram R. Prenatal Exposures to Persistent and Non-Persistent Organic Compounds and Effects on Immune System Development. J Compilation. 2008;102:146-54

Hirose J, Ito S, Hirata N, Kido S, Kitabatake N, Narita H. Occurrence of the major food allergen, ovomucoid, in human breast milk as an immune complex. Biosci Biotechnol Biochem. 2001;65(6):1438-40.

Holgate ST, Polosa R. Treatment strategies for allergy and asthma. Nat Rev Immunol. 2008;8:218-30.

Holloway JA, Warner JO, Vance GHS, Diaper ND, Warner JA, Jones CA. Detection of house-dust-mite allergen in amniotic fluid and umbilical-cord blood. The Lancet. 2000; 356(9245):1900-2

Holt PG, Batty JE, Turner KJ. Inhibition of specific IgE responses in mice by preexposure to inhaled antigen. Immunology. 198;42:409-17.

Holt PG, O'Keeffe PO, Holt BJ, Upham JW, Baron-Hay MJ, et al. T-cell "priming" against environmental allergens in human neonates: sequential deletion of food antigen reactivity during infancy with concomitant expansion of responses to ubiquitous inhalant allergens. Pediatr Allergy Immunol. 1995;6:85-90

Holt PG, Thomas WR. Sensitization to airborne environmental allergens: unresolved issues. Nat Immunol. 2005;6(10)957-60

Host A, Husby S, Hansen LG, Osterballe O. Bovine b-lactoglobulin in human milk from atopic and non-atopic mothers. Relationship to maternal intake of homogenized and unhomogenized milk. Clin Exp Allergy. 1990;20:383-7.

Host A, Husby S, Osterballe O. A prospective study of cow's milk allergy in exclusively breast-fed infants. Acta Paediatr Scand. 1988;77:663-70.

Host A, Koletzko B, Dreborg $S$ et al. Dietary products used in infants for treatment and prevention of food allergy. Jointstatement of the European Society for Paediatric allergology and Clinical Immunology (ESPACI) Committee on HypoallergenicFo rmulas and the European Society for Paediatric Gastroenterology, Hepatology and Nutrition (ESPGHAN) Committee on Nutrition. Arch Dis Child. 1999;81:80-4.

Hurley WL, Theil PK. Perspectives on Immunoglobulins in Colostrum and Milk. Nutrients. 2011;3:442-74. 
Husby S, Oxelius VA, Teisner B, Jensenius JC, Svehag SE. Humoral immunity to dietary antigens in healthy adults. Occurrence, isotype and IgG subclass distribution of serum antibodies to protein antigens . Int Arch Allergy Appl Immunol. 1985;77, 416-22.

Israel EJ, Taylor S, Wu Z et al. Expression of the neonatal Fc receptor, FcRn, on human intestinal epithelial cells. Immunology. 1997;92:69-74.

Jackson PG, Lessof MH, Baker RW, Ferrett J, MacDonald DM. Intestinal permeability in patients with eczema and food allergy. Lancet. 1981;1:1285-6.

Jacquet A.The role of innate immunity activation in house dust mite allergy. Trends in Molecular Medicine. 2011;17(10):604-11.

Jakobsson I, Lindberg T, Benediktsson B, Hansson B-G. Dietary bovine blactoglobulin is transferred to human milk. Acta Paediatr Scand. 1985;74:342-5.

Janzi M, Kull I, Sjoberg R et al. Selective IgA deficiency in early life: association to infections and allergic diseases during childhood. Clin Immunol. 2009;133:78-85.

Jarrett EEE, Hall E. IgE suppression by maternal IgG. Immunology. 1983;48:49-57.

Jarvis D, Zock JP, Heinrich J, Svanes C, Verlato G, Olivieri M, Villani S, Ponzio M, Leynaert B, Sunyer J, Dahlman-Hoglund A, Chinn S, Luczynska C, Norbäck D, Burney $P$. Cat and dust mite allergen levels, specific $\lg G$ and $\lg G 4$, and respiratory symptoms in adults. J Allergy Clin Immunol. 2007;119(3):697-704.

Jenmalm MC, Holt PG, Björkstén B. Maternal influence on IgG subclass antibodies to Bet $v 1$ during the first 18 months of life as detected with a sensitive ELISA. Allergy Immunol. 1997;114:75

Jenmalm MC; Björkstén B. Cord blood levels of immunoglobulin G subclass antibodies to food and inhalant allergens in relation to maternal atopy and the development of atopic disease during the first 8 years of life. Clin Expl Allergy. 2000; 30(1):34-40.

Jones CA, Holloway JA, Warner JO. Fetal immune responsiveness and routes af allergic sensitization. Pediatric Allergy and Immunology. 2002;13 (Suppl. 15):19-22.

Kalliomaki $\mathrm{M}$, Ouwehand $\mathrm{A}$, Arvilommi $\mathrm{H}$, Kero $\mathrm{P}$, Isolauri $\mathrm{E}$ : Transforming growth factor-beta in breast milk: a potential regulator of atopic disease at an early age. $\mathrm{J}$ Allergy Clin Immunol. 1999;104:1251-7.

Karmaus $\mathrm{W}$, Arshad $\mathrm{H}$, Mattes $\mathrm{J}$. Does the sibling effect have its origin in utero? investigatin birth order, cord blood immunoglobulin $\mathrm{E}$ concentration, and allergic sensitization at age 4 years. Am J Epidemiol. 2001;154:909-15. 
Kauffman HF, Tamm M, Timmerman JAB e Borges P.House dust mite major allergens Der $\mathrm{p} 1$ and Der $\mathrm{p} 5$ activate human airway-derived epithelial cells by protease-dependent and protease-independent mechanisms. Clin Mol Allergy. 2006; 28;4:5.

Kaufmann P, Huppertz B, Frank HG. The fibrinoids of the human placenta: origin, composition and functional relevance. Ann Anat. 1996;178(6):485-501 .

Kilshaw PJ, Cant AJ. The passage of maternal dietary proteins into human breast milk. Int Arch Allergy Appl Immunol. 1984;75:8-15.

Kohler PF, Farr RS. Elevation of cord over maternal IgG immunoglobulin: evidence for an active placental IgG transport. Nature. 1966;210:1070-5.

Komatsu T, Okao M, Miyamoto $\mathrm{H}$, Chen T, Shinka S.Effects of early antigen exposure through lactation on later specific antibody responses in mice. $J$ Immunol. 1988;141(9):2895-906.

Korotkova M, Telemo E, Yamashiro Y, Hanson LA, Strandvik B.. The ratio of n-6 to n3 fatty acids in maternal diet influences the induction of neonatal immunological tolerance to ovalbumin. Clin Exp Immunol. 2004;137(2):237-44.

Kramer MS, Matush L, Vanilovich I, et al. Promotion of Breastfeeding Intervention Trial (PROBIT) Study Group. Effect of prolonged and exclusive breast feeding on risk of allergy and asthma: cluster randomised trial. BMJ. 2007;335(7624):815.

Kull I, Almqvist C, Lilja G, Pershagen G, Wickman M. Breast-feeding reduces the risk of asthma during the first 4 years of life. J Allergy Clin Immunol. 2004;114:755-60.

Lambrecht BN, Hammad $\mathrm{H}$. The airway epithelium in asthma. nature medicine. 2012;18(5):684-92.

Lawrence RM, Pane CA. Human breast milk: Current concepts of Immunology and infectious diseases. Curr Probl Pediatr Adolesc Health Care. 2007;1:7.

Lovegrove JA, Morgan JB, Hampton SM. Dietary factors influencing levels of food antibodies and antigens in breast milk. Acta Paediatr 1996;85:778-84.

Macchiaverni P, Rekima A; Tulic MK, Verhasselt V. L'allaitement maternel peut-il prévenir les maladies allergiques parl'induction de tolérance orale? Possible prevention of allergic disease by breastfeeding induced oral tolerance. Revue Française d'Allergologie. 2012. In press.

Macchiaverni P, Tulic MK, Verhasselt V. Antigens in Breast Milk: Possible Impact on Immune System Education; Dietary and nutritional aspects of human breast milk. Wageningen Academic Publishers. 2012. In press. 
Machiels JJ, Somville MA, Lebrun PM, Lebecque SJ, Jacquemin MG, Saint-Remy JM. Allergic bronchial asthma due to Dermatophagoides pteronyssinus hypersensitivity can be efficiently treated by inoculation of allergen-antibody complexes. J Clin Invest. 1990;85(4):1024-35.

Machiels JJ, Lebrun PM, Jacquemin MG, Saint-Remy JM. Significant reduction of nonspecific bronquial reactivity in patients with Dermatophagoides pteronyssinussensitive allergic asthma under therapy with allergen-antibody complexes. Am Rev Respir Dis. 1993;147(6 Pt 1):1407-12.

Machtinger S, Moss R. Cow's milk allergy in breast-fed infants: the role of allergen and maternal secretory IgA antibody. J Allergy Clin Immunol. 1986;77:341-7.

Malek A, Sager R, Sakher A, Schneider $H$. Transporto $f$ immunoglobulin $G$ and its subclasses across the in vitro perfused human placenta. Am. J. Obst. Gynecol. 1995; 173:760-7.

Mariani M-P, Price JF, Kemeny DM. The IgG subclass antibody response to an inhalant antigen (Dermatophagoides pteronyssinus) during the first year of life: evidence for early stimulation of the immune system following natural exposure. Clin Exp Allergy. 1992;22:29-33.

Marks GB, Zhou J, Yang HS et al. Cord blood mononuclear cell cytokine responses in relation to maternal house dust mite allergens exposure. Clin Exp Allergy. 2002;32:355-60.

Martinez RD. The coming-of-age of the hygiene hypothesis. Respr res. 2001;2:12932

Medeiros Jr. M, Figueredo JP. Sensibilização a ae-roalérgenos em indivíduos portadores de asma brônquica e / ou rinite crônica em Salvador, Bahia. Rev bras alerg imunopatol. 1997;20:143-54.

Melkild I, Groeng EC, Leikvold RB, Granum B, Lovik M. Maternal allergen immunization during pregnancy in a mouse model reduces adult allergy-related antibody responses in the offspring. Clin Exp Allergy. 2002;32:1370-6.

Miller RL, Chew GL, Bell CA, Biedermann SA, Aggarwal M, Kinney PL, Tsai WY, Whyatt RM, et al. Prenatal exposure, maternal sensitization, and sensitization in utero to indoor allergens in an inner-city cohort. Am J Respir Crit Care Med. 2001;164(6):995-1001.

Montealegre F, Sepulveda A, Bayona M, Quiñones C, Fernández-Caldas E. Identification of the domestic mite fauna of Puerto Rico. Health Sci J. 1997;16(2):109. 
Moraes-Pinto MI, lazzeti AV, Farhat CL. Transporte transplacentário de anticorpos: implicações na proteção do recém nascido e em estratégias de imunização. Rev Paula Ped. 2001;19:87-92.

Morel PA, Oriss TB. Crossregulation between Th1 and Th2 cells. Crit Rev Immunol. 1998;18(4)275-303.

Mori JC, Pires MC, Galvão CE, Ferreira de Melo J, Golcher FM, Montealegre F. Determination of Blomia tropicalis-specific $\operatorname{lgE}$ and $\lg G$ subclasses in atopic dermatitis patients. Allergy. 200;56(2):180-4.

Mosconi E, Rekima A, Seitz-Polski B, Kanda A, Fleury S, Tissandie E, Monteiro R, Dombrowicz DD, Julia V, Glaichenhaus N, Verhasselt V. Breast milk immune complexes are potent inducers of oral tolerance in neonates and prevent asthma development. Mucosal Immunol. 2010;3(5):461-74.

Nadchatram M. House dust mites, our intimate associates. Trop Biomed. 2005; 22(1):23-37.

Nafstad P, Magnus P, Gaarder P I, Jackola JJ. Exposure to pets and atopy-related diseases in the first 4 years of life. Allergy. 2001;56:307.

Neville MC, Keller RP, Seacat J, Casey CE, Allen JC, Archer P. Studies on human lactation. I. Withinfeed and between-breast variation in selected components of human milk. Am J Clin Nutr. 1984;40:635-46.

Odelram H, Bjorksten B, Leander E, Kjellman NI. Predictors of atopy in newborn babies. Allergy. 1995;50:585-92.

Okahata H, Nishi Y, Mizoguchi N, Yumiba C, Fujii H, Ueda K. Development of serum Dermatophagoides farinae-,ovalbumin- and lactobumin- specific lgG, IgG1, IgG4, IgA and IgM in children with bronchial asthma/allergic rhinitis or atopc dermatitis. Clin. Exp. Allergy. 1990;20(1):39-44.

Okoko BJ, Wesumperuma HL, Yamuah JFLK, and Hart CA. The transplacental transfer of $\operatorname{lgC}$ subclasses:influence of prematurity and low birthweight in the Gambianpopulation. Ann Trop Paediatr. 2002;22(4)325-32.

Oliveira CH, Binotti RS. House dust mites in matresses in the city of Campinas - SP. Rev Bras Alerg Imunopatol. 1999;22(6):188-97.

Palmeira P, Costa-Carvalho BT, Arslanian C, Pontes GN, Nagao AT, CarneiroSampaio MM. Transfer of antibodies across the placenta and in breast milk from mothers on intravenous immunoglobulin. Pediatr Allergy Immunol. 2009;20:528-35. 
Palmeira P, Quinello C, Silveira-Lessa AL, Zago CA, Carneiro-Sampaio M. IgG placental transfer in healthy and pathological pregnancies. Clin Dev Immunol. 2012;2012:985646.

Palmer DJ, Gold MS, Makrides M. Effect of cooked and raw egg consumption on ovalbumin content of human milk: a randomized, double-blind, cross-over trial. Clin Exp Allergy. 2005;35:173-8.

Palmer DJ, Makrides M. Diet of lactating women and allergic reactions in their infants. Curr Opin Clin Nutr Metab Care. 2006;9:284-8

Palmer DJ, Gold MS, Makrides M. Effect of maternal egg consumption on breast milk ovalbumin concentration. Clin Exp Allergy. 2008;38:1186-91.

Penttila I: Effects of transforming growth factor-beta and formula feeding on systemic immune responses to dietary beta-lactoglobulin in allergy-prone rats. Pediatr Res. 2006;59:650-5.

Penttila IA, Flesch IE, McCue AL, Powell BC, Zhou FH, Read LC, Zola H: Maternal milk regulation of cell infiltration and interleukin 18 in the intestine of suckling rat pups. Gut. 2003;52:1579-86.

Pereira EAL, Silva DAO, Cunha-Junior JP, Almeida KC, Alaves R, Sung SJ, Taketomi EA. IgE, IgG1 and IgG4 antibody responses to Blomia tropicalis in atopic patients. Allergy. 2005;60:401-6.

Pilette C, Durham SR, Vaerman JP, Sibille Y. Mucosal immunity in asthma and chronic obstructive pulmonary disease: a role for immunoglobulin A? Proc Am Thorac Soc. 2004;1:125-35.

Platts-Mills TA, Thomas WR, Aalberse RC, Vervloet D, Champman MD. Dust mite allergens and asthma: report of a second international workshop. J Allergy Clin Immunol. 1992;89:1046-60.

Platts-Mills TAE, Erwin EA, Allison AB, Blumenthal K, Barr M, Sredl D, Burge H, Gold $D$. The relevance of maternal immune responses to inhalant allergens to maternal symptoms, passive transfer to the infant, and development of antibodies in the first 2 years of life. J allergy Clin Immunol. 2003;30:111-23.

Polte T, Hennig C, Hansen G. Allergy prevention starts before conception: Maternofetal transfer of tolerance protects against the development of asthma. J Allergy Clin Immunol. 2008;122:1022-30.

Prescott SL, Smith P, Tang M, et al. The importance of early complementary feeding in the development of oral tolerance: concerns and controversies. Pediatr Allergy Immunol. 2008; 19,375-80. 
Prescott S, Allen KJ. Food allergy: riding the second wave of the allergy epidemic. Pediatr Allergy Immunol. 2011;22(2):155-60.

Prescott SL, Holt PG, Jenmalm M, Björkstén B. Effects of maternal allergen-specific IgG in cord blood on early postnatal development of allergen-specific T-cell immunity. Allergy. 2000;55:470-5.

Prescott SL. Allergy: when does it begin and where will it end? Allergy. 2003;58:864.

Quinello C, Quintilio W, Carneiro-Sampaio M, Palmeira P. Passive acquisition of protective antibodies reactive with Bordetella pertussis in newborns via placental transfer and breast-feeding. Scand J Immunol. 2010;72(1):66-73.

Rizzo MC, Arruda LK, Chapman MD, Fernandez-Caldas E, Baggio D, Platts-Mills TA, Naspitz CK. IgG and IgE antibody responses to dust mite allergens among children with asthma in Brasil. Ann Allergy, 1993;71(2):152-8.

Rizzo MCV, Fernadez-Caldas E, Sole D, Naspitz CK. IgE antibodies to aeroallergens in allergic children in São Paulo, Brazil. J Investig Allergol Clin Immunol. 1997;7:2428.

Roopenian CD, Akilesh S. FcRn: the neonatal Fc receptor comes of age. Nat Rev Immunol. 2007;7:715-25.

Ruiter B, Knol EF, van Neerven RJ et al. Maintenance of tolerance to cow's milk in atopic individuals is characterized by high levels of specific immunoglobulin G4. Clin Exp Allergy. 2007;37:1103-10.

Sarinho E, Fernandez-Caldas E, Just E, Solé D. Ácaros da poeira domiciliar em residências de crianças asmáticas e controles da cidade de Recife-Per-nambuco. Rev bras alerg imunopatol. 1996;19:228-30.

Sarinho E, Rizzo MC, Just E, Fernandez-Caldas E, Sole D. Sensibilização aos ácaros domésticos em crianças atópicas e não-atópicas de Recife, PE, Brasil. Rev Bras Alerg Imunopatol. 2000;23:105-10.

Savilahti E, Siltanen M, Kajosaari M, Vaarala O, Saarinen KM. IgA antibodies, TGFbeta1 and -beta2, and soluble CD14 in the colostrum and development of atopy by age 4. Pediatr Res. 2005;58:1300-5.

Savilahti E, Tainio VM, Salmenpera L et al. Low colostral IgA associated with cow's milk allergy. Acta Paediatr Scand. 1991;80:1207-13.

Scholtens S, Wijga AH, Brunekreef B, Kerkhof M, Hoekstra MO, Gerritsen J, Aalberse R, de Jongste JC, Smit HA. Breast feeding, parental allergy and asthma in children followed for 8 years. The PIAMA birth cohort study Thorax. 2009;64(7):6049. 
Schulz O, Sewell HF, Shakib F. Proteolytic cleavage of CD25, the alpha subunit of the human $\mathrm{T}$ cell interleukin 2 receptor, by Der $\mathrm{p} 1$, a major mite allergen with cysteine protease activity. J Exp Med. 1998;187(2):271-5.

Schwarze J, Cieslewicz G, Joetham A, Sun LK, Sun WN, Chang TW, Hamelmann E, Gelfand EW. Antigen-specific Immunoglobulin-A Prevents Increased Airway responsiveness and Lung Eosinophilia after Airway Challenge in Sensitized Mice. Am J Respir Crit Care Med. 1998;158:519-25.

Scirica CV, Gold DR, et al. Predictors of cord blood IgE levels in children at risk for asthma and atopy. J Allergy Clin Immunol, 2007;119(1):81-8.

Sears MR, Greene JM, Willan AR, Taylor DR, Flannery EM, Cowan JO, et al. Longterm relation between breastfeeding and development of atopy and asthma in children and young adults: a longitudinal study. Lancet. 2002;360:901-7.

Seeger M, Thierse HJ, Lange H, Shaw L, Hansen H, Lemke H. Antigen-independent suppression of the $\mathrm{IgE}$ immune response to bee venom phospholipase A2 by maternally derived monoclonal IgG antibodies. Eur J Immunol. 1998;28:2124-30.

Seenger $M$, Thierse $H J$, Lange $H$, Shaw L, Hansen $H$, Lemke $H$. Antigenindependent suppression of the $\lg E$ immune response to bee venon phospholipase A2 by maternaly derived monoclonal IgG antibodies. Eir J Immunol. 1998;28:212430.

Serravalle K, Medeiros M. House dust mites in the city of Salvador-BA. Rev Bras Alerg Imunopatol. 1999;22(1):19-24

Sigal LH. Basic Science for the Clinician 58. IgG Subclasses. J Clin Rheumatol 2012;18:316-8

Silva DR, Binotti RS, Silva CM, Oliveira $\mathrm{CH}$, Condino-Neto A, Capitani EM. Mites in dust samples from mattress surfaces from single beds or cribs in the south Brazilian city of Londrina. Pediatric Allergy and Immunology. 2005;16:132-6.

Silva DR, Binotti RS, Silva CM, Oliveira CH, Condino-Neto A, Capitani EM. Avaliação do ambiente domiciliar e da sensibilidade cutânea imediata de pacientes atópicos na cidade de Londrina-PR. Revista de Ciências Médicas. Revista de Ciências Médicas. 2005;14(2)167-73.

Simister EM, Story MG. Human placental Fc receptor and the transmission of antibodies from mother to fetus. J Reprod Immunol. 1997;37:1-23.

Simister NE. Placental transport of Immunoglobulin G. Vaccine. 2003;21:3365-9. 
Sinclair NR, Lees RK, Abrahams S, Chan PL, Fagan G, Stiller CR. Regulation of the immune response. X. Antigen-antibody complex inactivation of cells involved in adoptive transfer. J Immunol. 1974;113(5):1493-500

Sletten GB, Halvorsen R, Egaas E, Halstensen TS. Casein-specific immunoglobulins in cow's milk allergic patient subgroups reveal a shift to IgA dominance in tolerant patients. Pediatr Allergy Immunol. 2007;18:71-80.

Smillie FI, Elderfield AJ, Patel F, Cain G, Tavenier G, Brutsche M, Craven M, Custovic A, Woodcock A. Lymphoproliferative responses in cord blood and at one year: no evidence for the effect of in utero exposure to dust mite allergens. Clin Exp Allergy. 2001;31(8):1194-204.

Smits $\mathrm{HH}$, Gloudemans $\mathrm{AK}$, van Nimwegen $\mathrm{M}$ et al. Cholera toxin B suppresses allergic inflammation through induction of secretory IgA. Mucosal Immunol. 2009;2:331-9.

Solé D, Camelo-Nunes IC, Wandalsen GF, Rosário Filho NA, Naspitz CK. Prevalence of rhinitis among Brazilian schoolchildren: ISAAC phase 3 results. Rhinology. 2007;5(2):122-8.

Sorva R, Mäkinen-Kiljunen S, Juntunen-Backman K. Beta-lactoglobulin secretion in human milk varies widely after cow's milk ingestion in mothers of infants with cow's milk allergy. J Allergy Clin Immunol. 1994;93(4):787-92.

Spieksma FT, Dieges PH. The history of the finding of the house dust mite. J Allergy Clin Immunol. 2004;(3):573

Stewart GA, Dowse GK, Turner KJ, Alpers MP. Isotype specific immunoglobulin responses to the house dust mite Dermatophagoides pteronyssinus and the purifield allergen Der $p 1$ in asthmatic and control subjects from the Eastern Highlands of Papua New Guinea. Clin Allergy. 1988;18(3):235-43.

Stewart GA, Boyd SM, Bird CH, Krska KD, Kollinger MR, Thompson PJ. Immunobiology of the serine protease allergens fromhouse dust mites. Am. J. Ind.Med. 1994;25:105-7.

Strait RT, Morris SC, Finkelman FD. IgG-blocking antibodies inhibit IgE-mediated anaphylaxis in vivo through both antigen interception and Fc gamma Rllb crosslinking. J Clin Invest. 2006;116:833-41.

Stuart CA, Twiselton R, Nicholas MK, Hide DW. Passage of cows' milk protein in breast milk. Clin Allergy. 1984;14:533-5.

Suyer J, AntoJM, Harris J, Torrent M, Vall O, Cullman O et al. Maternal atopy and parity. Clin exp Allergy. 2001;31:1352-5 
Szépfalusi Z, Loibichler C, Hänel-Dekan S, Dehlink E, Gerstmayr M, Pichler J, Eiwegger $T$, Horvat $R$, Urbanek R. Most of diaplacentally transferred allergen is retained in the placenta. Clin Exp Allergy. 2006;36(9):1130-7.

Szépfalusi Z, Pichler J, Elsässer S, van Duren K, Ebner C, Bernaschek G, Urbanek $R$. Transplacental priming of the human immune system with environmental allergens can occur early in gestation. J Allergy Clin Immunol. 2000;106(3):530-6.

Terreehorst I, Hak E, Oosting AJ, Tempels-Pavlica Z, de Monchy JG, BruijnzeelKoomen CA, Aalberse RC, Gerth van Wijk R.Evaluation of impermeable covers for bedding in patients with allergic rhinitis. N Engl J Med. 2003;17;349(3):237-46.

The Global Asthma Report 2011. [cited from 2011 Oct 29]. Available from: http://www.globalasthmareport.org/

Thomas WR, Smith WA, Hales BJ, Mills K, O'Brien RM. Characterization and immunobiology of house dust mite allergens. Int Arch Allergy Immunol. 2002;129:118.

Thomas WR, Hales BJ, Smith WA. Structural biology of allergens. Curr.Allergy Asthma Rep. 2005;5:388-93.

Thorton CA, Vance SHG. The placenta: a portal of fetal allergen exposure. Clin Exp Allergy. 2002;32:1537-9.

Trompette A, Divanovic S, Visintin A, et al. Allergenicity resulting from functional mimicry of a Toll-like receptor complex protein. Nature. 2009;457:585-8.

Troncone R, Scarcella A, Donatiello A, et al. Passage of gliadin into human breast milk. Acta Paediatr Scand.1987;76:453-6.

Tsai JJ, Wu HH, Shen HD, Hsu EL, Wang SR. Sensitization to Blomia tropicalis among asthmatic patients in Taiwan. Int Arch Allergy Immunol. 1998;115(2):144-9.

Tsai JJ, Yi FC, Chua KY, Liu YH, Lee BW, Cheong N. Identification of the major allergenic components in Blomia tropicalis and the relevance of the specific $\lg E$ in asthmatic patients. Ann Allergy Asthma Immunol. 2003;91(5):485-9.

Tulic MK, Hodder M, Forsberg A, McCarthy S, Richman T, D'Vaz N, et al. Differences in innate immune function between allergic and nonallergic children: new insights into immune ontogeny. J Allergy Clin Immunol. 2011;127:470-8 e1.

Turcanu V, Maleki SJ, Lack G. Characterization of lymphocyte responses to peanuts in normal children, peanut-allergic children, and allergic children who acquired tolerance to peanuts. J Clin Invest. 2003;111:1065-72. 
Uthoff H, Spenner A, Reckelkamm W, et al. Critical Role of Preconceptional Immunization for Protective and Nonpathological Specific Immunity in Murine Neonates. J Immunol. 2003;171:3485-92.

Vadas $\mathrm{P}$, Wai $\mathrm{Y}$, Burks W, Perelman B. Detection of peanut allergens in breast milk of lactating women. JAMA. 2001;285:1746-8.

van Bronswijk JE, Sinha RN. Pyroglyphid mites (Acari) and house dust allergy. J Allergy. 1971;47:31-52

van Odijk J, Kull I, Borres MP, et al. Breastfeeding and allergic disease: a multidisciplinary review of the literature (1966-2001) on the mode of early feeding in infancy and its impact on later atopic manifestations. Allergy. 2003;58:833-43.

van Vlasselaer P, Punnonen J, de Vries JE. Transforming growth factor-beta directs IgA switching in human B cells. J Immunol. 1992;148:2062-7.

Vance GHS, Lewis SA, Grimshaw KEC, et al. Exposure of the fetus and infant to hens' egg ovalbumin via the placenta and breast milk in relation to maternal intake of dietary egg. Clin Exp Allergy. 2005;35:1318-26.

Verhasselt V, Milcent V, Cazareth J, Kanda A, Fleury S, Dombrowicz D, Glaichenhaus N, Julia V. Breast milk-mediated transfer of an antigen induces tolerance and protection from allergic asthma. Nature Med. 2008;14(2):170-5.

Verhasselt V. Oral tolerance in neonates: from basics to potential prevention of allergic disease. Mucosal Immunol. 2010;3(4):326-33.

Victor JR, Fusaro AE, Duare AJS, Sato MN. Preconception maternal immunization to dust mite inhibits the type I hypersensitivity response of offspring. J Allergy Clin Immunol. 2003;11:269-77.

Victor JR, Muniz BP, Fusaro AE, et al. Maternal immunization with ovalbumin prevents neonatal allergy development and up-regulates inhibitory receptor Fc gamma RIIB expression on B cells. BMC Immunol. 2010;11:11.

Wan H, Winton HL, Soeller C, Gruenert DC, Thompson PJ, Cannell MB, Stewart GA, Garrod DR, Robinson C. Quantitative structural and biochemical analyses of tight junction dynamics following exposure of epithelial cells to house dust mite allergen Der p 1. Clin Exp Allergy. 2000;30(5):685-98.

Willoughby JB, Willoughby WF. In vivo responses to inhaled proteins. I. Quantitative analysis of antigen uptake, fate, and immunogenicity in a rabbit model system. $\mathrm{J}$ Immunol. 1977;119(6):2137-46.

Woodcock A, Forster L, Matthews E, Martin J, Letley L, Vickers M, Britton J, Strachan D, Howarth P, Altmann D, Frost C, Custovic A; Medical Research Council 
General Practice Research Framework. Control of exposure to mite allergen and allergen-impermeable bed covers for adults with asthma. $N$ Engl $\mathrm{J}$ Med. 2003;17,349(3):225-36

Wright AL, Holberg CJ, Taussig LM, Martinez FD.Factors influencing the relation of infant feeding to asthma and recurrent wheeze in childhood. Thorax. $2001 ; 56(3): 192-7$.

Yi FC, Lee BW, Cheong N, Chua KY. Quantification of Blo t 5 in mite and dust extracts by two-site ELISA. Allergy. 2005;60(1):108-12

Zock JP, Heinrich J, Jarvis D et al. Distribution and determinants of house dust mite allergens in Europe: the European Community Respiratory Health Survey II. J Allergy Clin Immunol. 2006;118:682-90. 


\section{APÊNCIDE A}

Macchiaverni, P.; Arslanian, C.; Frazão, J. B.; Palmeira, P.; Russo, M.; Verhasselt, V.; Condino-Neto, A. Mother to Child Transfer of IgG and IgA Antibodies Against Dermatophagoides pteronyssinus. Scandinavian Journal of Immunology.

2011;74:619-27. 


\title{
Mother to Child Transfer of IgG and IgA Antibodies Against Dermatophagoides pteronyssinus
}

\author{
P. Macchiaverni*, C. Arslanian*, J. B. Frazão*, P. Palmeira†, M. Russo*, V. Verhasselt $\dagger^{1} \&$ \\ A. Condino-Neto*1
}

*Department of Immunology, Institute of Biomedical Sciences, University of São Paulo, SP, Brazil; †Laboratory of Medical Investigation (LIM-36), Department of Pediatrics, Hospital das Clínicas, University of São Paulo Medical School, São Paulo, SP, Brazil; and \$Institut National de la Santé et de la Recherche Médicale (INSERM), U924 Université de Nice-Sophia Antipolis, Valbonne, France

Received 6 June 2011; Accepted in revised form 16 August 2011

Correspondence to: A. Condino-Neto, MD, PhD, Department of Immunology, Institute of Biomedical Sciences, University of São Paulo, 1730, Lineu Prestes Avenue, São Paulo, SP 05508-000, Brazil. E-mail: condino@icb.usp.br

${ }^{1}$ These authors contributed equally to this work.

\begin{abstract}
There is strong evidence from animal models that placental and/or breast milk-mediated transfer of maternal allergen-specific $\operatorname{IgG}$ prevents allergic immune responses in the progeny. Both human and animal data also point to $\mathrm{IgA}$ as having an important regulatory role. In contrast, little is known about maternal transfer of $\operatorname{IgG}$ and $\operatorname{IgA}$ specific for respiratory allergens in humans. Dermatophagoides pteronyssinus (Der $p$ ) is an indoor allergen that is a major cause of asthma worldwide. We analysed maternal to child Der p-specific IgG and IgA transfer in a cohort of 77 paired maternal and child samples. We found Der p-specific IgG and its IgG1, IgG2 and IgG4 subclasses in all cord blood samples. Except for IgG1, cord levels were higher in newborns from atopic mothers $(n=29)$ compared to non-atopic mothers $(n=48)$. Der p-specific IgA was found in all colostrum samples and levels were independent of maternal atopic status. Notably, anti-Der p IgG was also found in colostrum and levels were higher in atopic mothers. We believe that our work is a critical first step in the identification of early factors that may impact asthma development and should guide the development of clinical studies that assess whether Der p-specific $\operatorname{IgG}$ and $\operatorname{Ig} A$ protect children from allergy as demonstrated in animal models.
\end{abstract}

\section{Introduction}

Atopic asthma affects millions of children worldwide [1]. Pathogenesis of allergic disease results from complex interactions between genetic and environmental factors such as pollution, tobacco and microbial exposure including microbiota of the gastrointestinal tract. In most cases, symptoms of allergic asthma manifest in childhood, and the immunological changes leading to atopy can occur very early in life and even during gestation [2]. Thus, identifying early factors that predispose to asthma development may help to improve primary prevention.

During pregnancy, mothers transfer to the foetus immunoglobulins ( $\mathrm{Ig}$ ) that recognize antigens to which she has been exposed [3]. IgG is the main Ig isotype transferred across the placental barrier [3-5], and its subclasses are ordered according to their relative serum levels: $\operatorname{IgG} 1>\operatorname{IgG} 2>\operatorname{IgG} 3>\operatorname{IgG} 4 . \operatorname{IgG} 1$ and $\mathrm{IgG} 3$ are generally induced in response to protein antigens,
IgG2 is associated with polysaccharide antigens, and IgG4 class switching is stimulated by TH2-type cytokines [6].

After delivery, Ig can be transferred by breastfeeding as it is the most abundant Ig found in human milk [7]. Most studies in humans have focused on placental transfer of $\operatorname{IgG}$ or milk transfer of $\operatorname{IgA}$ molecules specific for microbial antigens and have demonstrated their role in infectious disease prevention $[7,8]$. There is also some evidence from animal models that transferred maternal Ig could exert a regulatory role in their progeny. Experimental data in rodents indicate that maternal allergen-specific $\operatorname{IgG}$ transferred by placenta and/or breastfeeding prevents allergic sensitization in the progeny $[2,9-16]$, and animal and human studies indicate that $\operatorname{IgA}$ can exert an immunoregulatory role [17-20]. In humans, only a few studies have demonstrated the presence of $\operatorname{IgG}[21,22]$ or $\operatorname{IgA}[23-26]$ specific for food and respiratory antigens in cord blood or breast 
milk, respectively. To date, no study has demonstrated the transfer of IgG specific for respiratory allergens by breast milk.

In this study, we investigated whether mothers can provide to their children antibodies specific for Dermatophagoides pteronyssinus (Der p), a major allergen in house dust and one of the most frequently implicated respiratory allergens in allergic asthma [27-30]. In particular, we assessed whether anti-Der $p$ antibodies were detected in cord blood and/or colostrum and whether maternal atopic status had any influence on the amount of antibody.

\section{Methods}

Study design. A total of 77 healthy mothers and their newborns were selected at Maternidade de Campinas Hospital in Campinas, São Paulo, Brazil, between February and July 2006. The selection criteria included mothers giving birth to healthy, full-term and adequate-for-gestational-age-weight infants. Demographic data and details about the antenatal care of the mothers were obtained from their medial records and a directed questionnaire. The information included maternal age, parity, medications during pregnancy and atopic status (e.g. atopic rhinitis or asthma) established by a typical clinical history. Total and Der p-specific IgE were assayed in blood samples from all mothers. Inclusion criteria for atopic mothers were clinical manifestations of rhinitis, asthma or atopic dermatitis and anti-Der $p$ IgE concentration $\geq 3.5 \mathrm{KU} / 1 \quad(n=29)$. A group of non-atopic healthy mothers (anti-Der $p \mathrm{IgE}$ concentration $\leq 0.3 \mathrm{KU} / 1$ and absence of atopic symptoms) was included in the study as a control group $(n=48)$. Exclusion criteria for enrolment of all mothers were hypertension, diabetes, infections, immunodeficiency, and those who had received corticosteroids, transfusion of blood-derived products or other drugs related to chronic diseases during pregnancy. The study was approved by the University of São Paulo Institute of Biomedical Sciences Ethics Committee in accordance with the Brazilian Ministry of Health Resolution 96/1996 and the Helsinki Declaration.

Serum and colostrum samples. After mothers signed the informed consent, cord blood was collected from large veins on the foetal side of the placenta immediately after delivery. Maternal peripheral venous blood and colostrum samples were collected within $48 \mathrm{~h}$ after delivery. Approximately $5 \mathrm{ml}$ of colostrum was collected manually and, on the same day, centrifuged for $30 \mathrm{~min}$ at $160 \mathrm{~g}$ at $4{ }^{\circ} \mathrm{C}$. The top layer of fat and the pellet were discarded, and the intermediate fluid fraction was aliquoted and stored at $-80{ }^{\circ} \mathrm{C}$ until analysed. Serum was separated from maternal and cord blood and stored at $-80{ }^{\circ} \mathrm{C}$ until assayed.

Total and Der p-specific IgE quantification. Total and anti-Der $p$ IgE antibodies from maternal serum samples were analysed by chemiluminescent immunoassay (ADVIA Centaur ${ }^{\circledR}$ and Cap System Pharmacia ${ }^{\circledR}$, respectively), according to manufacturer's recommendations [31].

In the Cap System Pharmacia ${ }^{\circledR}$ assay, the specific $\mathrm{IgE}$ concentration is expressed in $\mathrm{KU} / \mathrm{l}$; values $\geq 3.5 \mathrm{KU} / \mathrm{l}$ were considered positive for specific IgE. In the ADVIA Centaur $^{\circledR}$ assay, total $\operatorname{IgE}$ concentration is expressed in $\mathrm{IU} / \mathrm{ml}$, with a detection level of $1.5 \mathrm{IU} / \mathrm{ml}$.

Total $\operatorname{IgA}$ quantification. Total $\operatorname{IgA}$ was measured in colostrum samples by enzyme-linked immunosorbent assays (ELISA), as described [32] with modifications. Briefly, colostrum samples were diluted $1: 10,000$ in duplicate and incubated for $2 \mathrm{~h}$ in anti-human $\operatorname{IgA}$ (I0884; Sigma, St. Louis, MO, USA) coated plates. As a standard, we used IgA purified from human colostrums (I-2636; Sigma), and as secondary antibody, peroxidaseconjugated anti-human IgA (A0295; Sigma) diluted 1:6000 (1 h $30 \mathrm{~min}$ ) was used. Ortho-phenylenediamine (OPD) was used as the chromogenic substrate, and $\operatorname{Ig} A$ concentration was expressed as $\mathrm{mg} / \mathrm{ml}$.

Anti-Der p IgG and IgA quantification. Microplates (Costar, Cambridge, MA, USA) were coated overnight at $4{ }^{\circ} \mathrm{C}$ with $5 \mu \mathrm{g} / \mathrm{ml}$ of Der $p$ extract from IPI-ASAAC, São Paulo, BR, or with Der $p$ extract from Greer Laboratories, Lenoir, NC, in phosphate-buffered saline (PBS). Both Der $p$ preparations gave similar results. Plates were then saturated with $5 \%$ non-fat dry milk in PBS-Tween $0.1 \%$ for $1 \mathrm{~h}$ at room temperature. Samples and secondary antibodies were added as described below and bound antibodies were revealed by the addition of a solution containing $0.4 \mathrm{mg} / \mathrm{ml} \mathrm{OPD}$ and $0.01 \% \mathrm{H}_{2} \mathrm{O}_{2}$ in $0.1 \mathrm{M}$ phosphate-citrate buffer ( $\mathrm{pH} 5.0$ ). After $30 \mathrm{~min}$ of incubation, the reaction was stopped with $50 \mu \mathrm{l}$ of $2.5 \mathrm{~N}$ $\mathrm{H}_{2} \mathrm{SO}_{4}$. Plates were washed with PBS-Tween $0.1 \%$ between each step. Optical absorbance at $492 \mathrm{~nm}$ was measured by a microplate reader (Labsystems Multiskan MS, Farnborough, Hampshire, UK).

For Ig detection, sample dilution and secondary antibodies were prepared as follows.

Serum anti-Der p IgG: Maternal and cord serum were added in duplicate at a dilution of 1:100 followed by twofold serial dilutions and incubated at $37{ }^{\circ} \mathrm{C}$ for $2 \mathrm{~h}$. HRPconjugated anti-human IgG (A8419; Sigma) at a dilution of 1:400 was used as secondary antibody and incubated at $37{ }^{\circ} \mathrm{C}$ for $2 \mathrm{~h}$. Results were expressed as arbitrary units $(\mathrm{AU}) / \mathrm{ml}$ obtained by comparison of optical density (OD) values of a serum pool (collected from 24 mothers with anti-Der $p \operatorname{IgE}$ concentration $\geq 17.5 \mathrm{KU} / \mathrm{l}$ ) and defined to contain $1000 \mathrm{AU} / \mathrm{ml}$ of anti-Der $p$ IgG.

Serum anti-Der p IgG subclasses: Paired maternal and cord serum samples were added in duplicate at dilutions of 1:5 (IgG1), 1:2 (IgG2) and 1:2 (IgG4), followed by twofold serial dilutions, and incubated for $1.5 \mathrm{~h}$ on Der p-coated plates. As secondary antibody, biotinylated anti-human IgG1 (555869; BD Pharmingen, San Diego, CA, USA), 
IgG2 (555874; BD Pharmingen) and IgG4 (555882; BD Pharmingen) were used at dilutions of 1:500, 1:1000 and $1: 100$, respectively, and incubated for $1.5 \mathrm{~h}$. This step was followed by incubation with streptavidin-HRP (554066; BD Pharmingen) diluted 1:500, 1:1000 and 1:500, respectively, for $1.5 \mathrm{~h}$. Concentrations were expressed as arbitrary units $(\mathrm{AU} / \mathrm{ml})$ as described previously.

Colostrum anti-Der p IgA: Colostrum samples in duplicate were diluted 1:100 followed by two steps of twofold serial dilutions and incubated at $37{ }^{\circ} \mathrm{C}$ for $2 \mathrm{~h}$ on purified Der $p$-coated plates. As secondary antibody, we used peroxidase-conjugated anti-human IgA (A0295; Sigma) diluted $1: 6000$ and incubated $1.5 \mathrm{~h}$ at $37^{\circ} \mathrm{C}$. The results were expressed as arbitrary units $(\mathrm{AU} / \mathrm{ml}$ ) obtained by comparison with a colostrum pool (collected from 24 mothers with anti-Der $p \mathrm{IgE}$ concentration $\geq 17.5 \mathrm{KU} / \mathrm{l}$ ) and defined to contain $1000 \mathrm{AU} / \mathrm{ml}$ of colostrum anti$\operatorname{Der} p \operatorname{IgA}$.

Colostrum anti-Der p IgG: Colostrum anti-Der $p$ IgG quantification was performed as described for colostrum anti-Der $p \operatorname{IgA}$ with some modifications: colostrum samples were diluted 1:2 and incubated at $37{ }^{\circ} \mathrm{C}$ for $2 \mathrm{~h}$ on purified $\operatorname{Der}$ p-coated plates. As secondary antibody, we used anti-human biotinylated IgG (555785; BD Pharmingen) followed by streptavidin-HRP (554066; BD Pharmingen), both diluted 1:500 and incubated for $1.5 \mathrm{~h}$ at $37^{\circ} \mathrm{C}$. OPD was used as the chromogenic substrate, and concentrations were expressed as arbitrary units $(\mathrm{AU} / \mathrm{ml})$ obtained by comparison with a colostrum pool as described previously.

Statistical analyses. Statistical analyses were performed using GRAPHPAD PRISM version 5.00 for Windows (GraphPad Software, San Diego, CA, USA). Dots represent individual data points, and horizontal lines, the medians of each group. Mann-Whitney test was used to determine statistical differences because the D'AgostinoPearson normality test was not passed. Kruskal-Wallis test was performed to compare more than two groups. When significant differences were found, a Mann-Whitney test was performed to determine which groups differed. Correlation coefficients of antibody levels in maternal serum versus colostrum or cord blood were determined using Spearman's tests. Two-tailed $P$-values $<0.05$ were considered statistically significant and graphically represented as $* P<0.05 ; * * P<0.01 ; * * * P<$ $0.001 ; * * * * P<0.0001$.

\section{Results}

\section{Characteristics of the study population}

The study population was divided into two groups according to maternal atopic status defined by the presence of anti-Der $p \operatorname{IgE} \geq 3.5 \mathrm{KU} / 1$ and associated allergic symptoms. The characteristics of the two groups are sum- marized in Table 1. Total and anti-Der $p$ IgE concentrations in blood samples from atopic mothers were significantly higher than non-atopic mothers (Table 1). Maternal age, infant weight and height, and male-tofemale ratios were similar between the two groups (Table 1).

\section{Der p-specific lgG in cord blood and maternal serum}

Anti-Der $p$ IgG was detected in cord blood of all neonates. Anti-Der $p$ IgG concentrations were significantly higher in cord blood of neonates from atopic mothers compared to neonates from non-atopic mothers (Fig. 1A and Table 2). In addition, neonatal anti-Der $p$ IgG correlated with anti-Der $p$ IgE levels in maternal blood (data not shown; Spearman $r=0.2, P=0.006$ ). Similarly to their children, atopic mothers showed higher concentration of anti-Der p IgG compared to non-atopic mothers (Fig. $1 \mathrm{~A}$ and Table 2), and Der p-specific IgG in maternal blood correlated with anti-Der $p$ IgE levels (Spearman $r=0.2, P=0.009)$. Anti-Der $p$ IgG levels in cord blood correlated strongly with the maternal concentration for both atopic and non-atopic groups (Fig. 1B). The ratio of cord blood to maternal blood anti-Der $p$ IgG levels was not affected by maternal antibody concentration (Fig. 1C).

\section{Der p-specific $\lg \mathrm{G} 1, \lg \mathrm{G} 2$ and $\lg \mathrm{G} 4$ in cord blood and} maternal serum

Anti-Der p IgG2 and IgG4 concentrations were significantly higher in cord blood of neonates of atopic mothers compared to non-atopic mothers (Fig. 2B,C and Table 2),

Table 1 Characteristics of the study population.

\begin{tabular}{lll}
\hline & Atopic $(n=28)$ & Non-atopic $(n=48)$ \\
\hline $\begin{array}{ll}\text { Mother } \\
\text { Total IgE }(\mathrm{UI} / \mathrm{ml})\end{array}$ & $263.2(17.3-3910) * * * *$ & $16.45(1.5-1543)$ \\
Der p-specific IgE & $20.7(3.4-100) * * * *$ & $<0.35(<0.35-<0.35)$ \\
(KU/ml) & & \\
Age (years) & $26.5(16-40)$ & $26.5(15-37)$ \\
Gestation, \% & & \\
(number) & & 35 \\
1 & 55 & 38 \\
2 & 31 & 17 \\
3 & 14 & 10 \\
$\geq 4$ & 0 & $3.3(2.4-4.5)$ \\
Newborn & & $49.1(44.5-52.8)$ \\
Weight $(\mathrm{kg})$ & $3.2(2.3-4.2)$ & 42 \\
Height $(\mathrm{cm})$ & $48.6(45-53)$ & 58 \\
Sex $(\%)$ & & \\
Male & 52 & \\
Female & 48 &
\end{tabular}

Data represent median values and range (shown in brackets). Results obtained in atopic and non-atopic groups were compared, and statistical difference was calculated by Mann-Whitney test. $* * * *$ Statisticaly significant values 

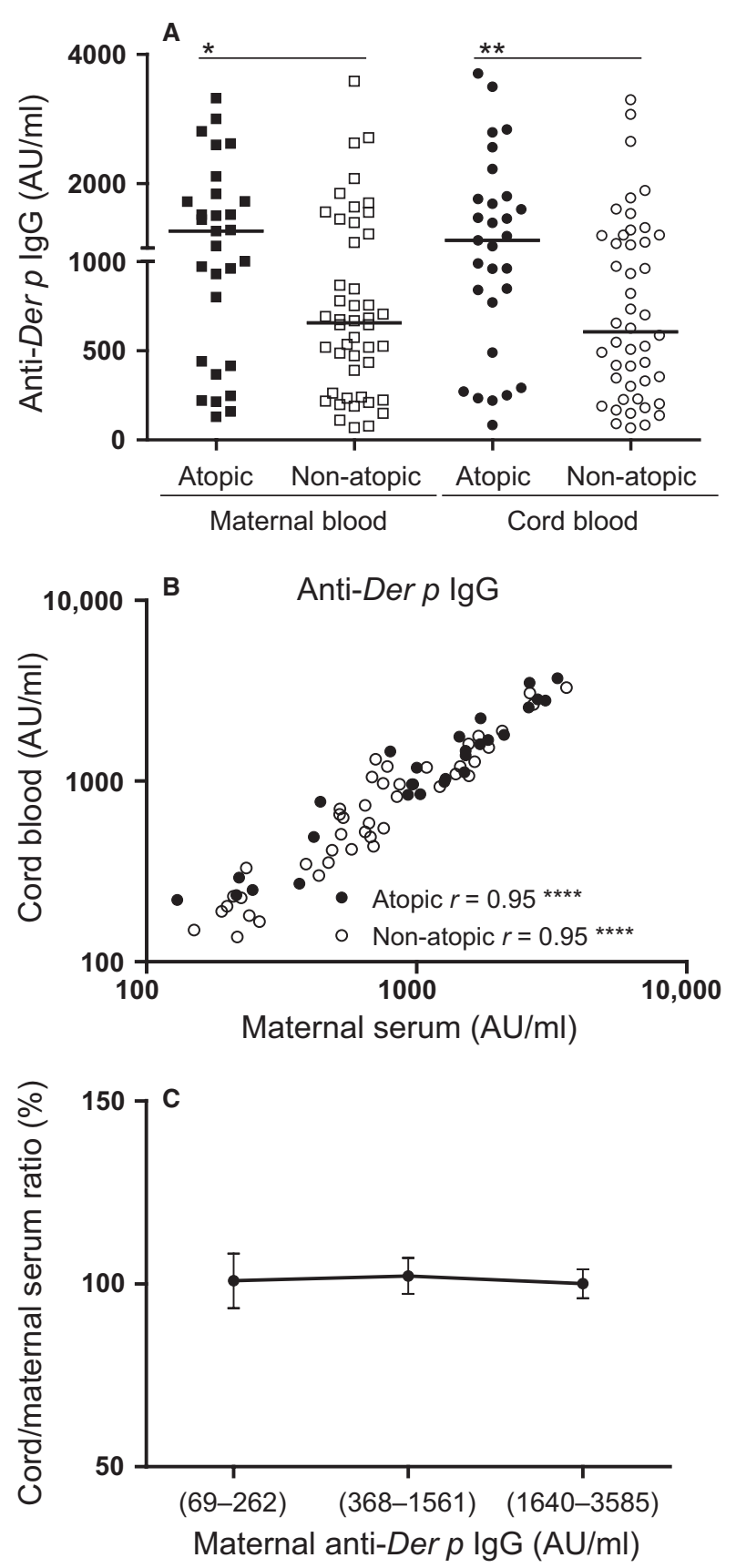

Figure 1 Der $p$-specific IgG concentration in maternal and cord blood. Der p-specific IgG levels were determined in paired maternal and cord blood samples. Data are compared according to maternal atopic status by Mann-Whitney test (A). Der p-specific IgG concentrations obtained in cord blood are correlated with concentrations in respective maternal blood by Spearman test (B). Cord/maternal serum ratios of Der p-specific $\operatorname{IgG}$ obtained at low, intermediate and high levels of respective maternal anti-Der $p \operatorname{IgG}$ levels (C).

while the anti-Der $p$ IgG1 concentration was equivalent in both groups (Fig. 2A and Table 2). Further, cord blood anti-Der $p \operatorname{IgG} 2$ and IgG4, but not IgG1, correlated with maternal anti-Der $p \operatorname{IgE}$ concentrations (Spearman $r=0.2, P=0.03$ and $r=0.5, P<0.0001$ for
$\operatorname{IgG} 2$ and IgG4, respectively). As observed in the neonates, maternal blood IgG2 and IgG4 levels were higher in the serum of atopic mothers compared to non-atopic, while IgG1 levels were similar in both groups (Fig. 2AC), and Der p-specific IgG subclasses in maternal blood correlated with anti-Der $p$ IgE levels with the exception of IgG1 (data not shown; Spearman $r=0.2, P=0.03$ and $r=0.5, P<0.0001$ for IgG2 and IgG4, respectively).

Cord blood anti-Der $p \operatorname{IgG} 1, \operatorname{IgG} 2$ and IgG4 correlated strongly with respective maternal levels in both groups (Fig. 2D-F), and the ratio of cord blood to maternal blood antibody levels decreased at high maternal antibody concentration (Fig. 2G-I). We also found that the ratio of cord blood to maternal serum anti-Der $p$ IgG1 was higher than for the other $\operatorname{IgG}$ subclasses in both groups (Table 2).

\section{Der $p$-specific $\lg A$ and $\lg G$ in colostrum}

Total and anti-Der $p \operatorname{IgA}$ were detected in all colostrum samples without significant differences between atopic and non-atopic mothers (Fig. 3A). For both groups, a positive correlation was found between total and anti-Der $p$ IgA concentrations in colostrum (Fig. 3B). We did not find any correlation between anti-Der $p \operatorname{IgA}$ levels in colostrum and anti-Der $p \operatorname{IgG}$ or IgE levels in maternal blood, as expected, because most of the $\operatorname{IgA}$ found in colostrum is produced peripherally, in mammary tissue.

In addition to anti-Der $p \operatorname{IgA}$, we found anti-Der $p$ IgG in all colostrum samples (Fig. 4 and Table 2). AntiDer $p \operatorname{IgG}$ concentrations in colostrum were higher in atopic mothers (Fig. 4A) and correlated with maternal anti-Der $p \quad \operatorname{IgE}$ concentrations (Spearman $r=0.3$; $P=0.002$ ). Colostrum anti-Der $p \mathrm{IgG}$ concentrations correlated with maternal blood anti-Der $p$ IgG in the non-atopic group but not in the atopic group (Fig. 4B).

\section{Discussion}

This study demonstrates the presence of Der p-specific $\operatorname{IgG}$ in all cord blood samples as well as Der p-specific $\operatorname{Ig} A$ and $\operatorname{IgG}$ in all colostrum samples. Others have previously shown the presence of $\operatorname{IgG}$ antibodies specific for respiratory antigens from birch pollen (Bet $v 1)$, cat (Fel d 1 ) and Dermatophagoides farinae (Der $f 1)$ in cord blood samples $[22,33,34]$. In those studies, not all samples were positive, which probably reflects differences in immunogenicity of the allergen tested and in the maternal exposure to the allergens. In this case, Der $p$ is an indoor allergen that is widely distributed in the humid regions of the world [27-30].

The analysis of $\operatorname{IgG}$ subclass concentrations in maternal and cord blood demonstrates that cord blood concentrations of anti-Der $p$ IgG, IgG1, IgG2 and IgG4 
Table 2 Der p-specific IgG levels in maternal serum and colostrum and neonate umbilical cord serum.

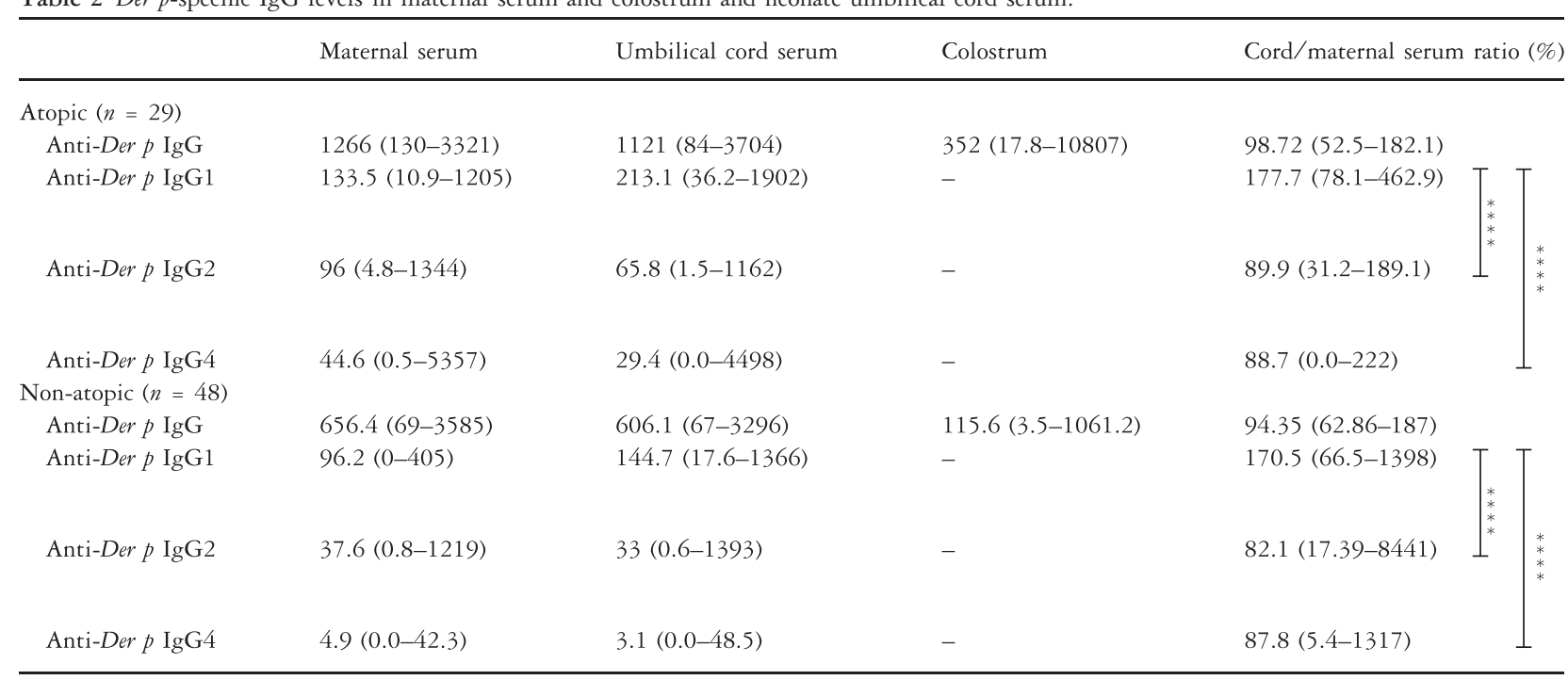

- , not performed.

Anti-Der p IgG levels are expressed in AU/ml. Data represent median values and ranges (shown in bracket). Cord/maternal serum ratios represent the median of the ratio calculated for each pair of cord/maternal samples. For both atopic and non-atopic group, we compared IgG1, IgG2 and IgG4 cord/maternal serum ratio.

$* * * *$ Statistically significant values.

correlated strongly with respective maternal values. We also found that both maternal serum and cord blood anti-Der $p$ IgG, IgG2 and IgG4 correlated with maternal $\mathrm{IgE}$ levels, and we found higher levels of IgG, IgG2 and IgG4 in cord blood of neonates from atopic mothers as compared to non-atopic mothers. Such correlation was not found for anti-Der $p \operatorname{IgG1}$, and concentrations of IgG1 were equivalent in both groups. In addition, as previously described by others [33], we detected anti-Der $p$ IgG and subclasses in maternal serum and cord blood in the absence of maternal Der $p$-specific IgE. In addition to the presence or absence of atopy, differences in maternal exposure to $\operatorname{Der} p$ could also be responsible for differences in IgG levels in maternal blood, colostrum and cord blood. Although we did not measure Der $p$ levels in subjects' homes, we did not favour this hypothesis because all subjects live in a region where $\operatorname{Der} p$ is found uniformly in very high concentration [35].

The source of the Der p-specific IgG found in cord blood might be of foetal origin as a result of in utero sensitization or might be of maternal origin as a result of maternal transfer across the placenta. Many studies have reported that allergen-specific IgE detected in cord blood is synthesized in utero and can be a marker of risk of atopic disease development in children [36-38]. However, this concept was recently challenged by Bonnelykke et al. $[4,5]$. Comparison of allergen-specific $\operatorname{IgE}$ in maternal and cord blood indicated that specific $\operatorname{IgE}$ in cord blood completely matched specific IgE in maternal blood with respect to allergen specificity, level of specific $\operatorname{IgE}$ and ratio of total $\mathrm{IgE}$ to specific $\mathrm{IgE}$. In addition, correspond- ing specific $\operatorname{IgE}$ was not found in infant blood at 6 months of age. These observations let the authors conclude that the presence of cord blood IgE was, in the majority of cases, a result of maternal transfer. Our results showed a strong correlation between cord blood anti-Der $p$ IgG, IgG1, IgG2 and IgG4 and respective maternal levels. Although we do not have data on IgG levels in children at 6 months of age, our data suggest a maternal transfer of anti-Der $p$ IgG subclasses across placenta.

In addition, the decreased ratio of cord blood to maternal levels of these antibodies at high maternal concentrations suggests a saturable receptor-mediated transfer. Notably, the syncytiotrophoblast expresses a neonatal Fc receptor $(F c R n)$ that is essential for IgG transfer [3, 39] and is saturable [40]. This receptor has a higher affinity for IgG1, compared to other IgG subclasses, which may explain the more efficient in utero transfer of Der $p$ specific IgG1, compared to other subclasses [3], as also shown here.

Several studies in rodents have reported that maternal allergen-specific IgG inhibits allergic responses in the offspring [2, 9-16]. Proposed mechanisms of protection by maternal IgG include the following: (1) IgG binding to allergen, leading to allergenic determinant masking and clearance of the immune complexes by phagocytosis, (2) IgG blockade of IgE binding to allergen and hence inhibition of mast cell degranulation and (3) interactions with inhibitory receptor Fc $\gamma$ RIIb on neonatal B lymphocytes or dendritic cells [2, 41]. More recently, protection from allergic airway disease by antigen transfer through breast milk was shown to be more stronger and of longer 

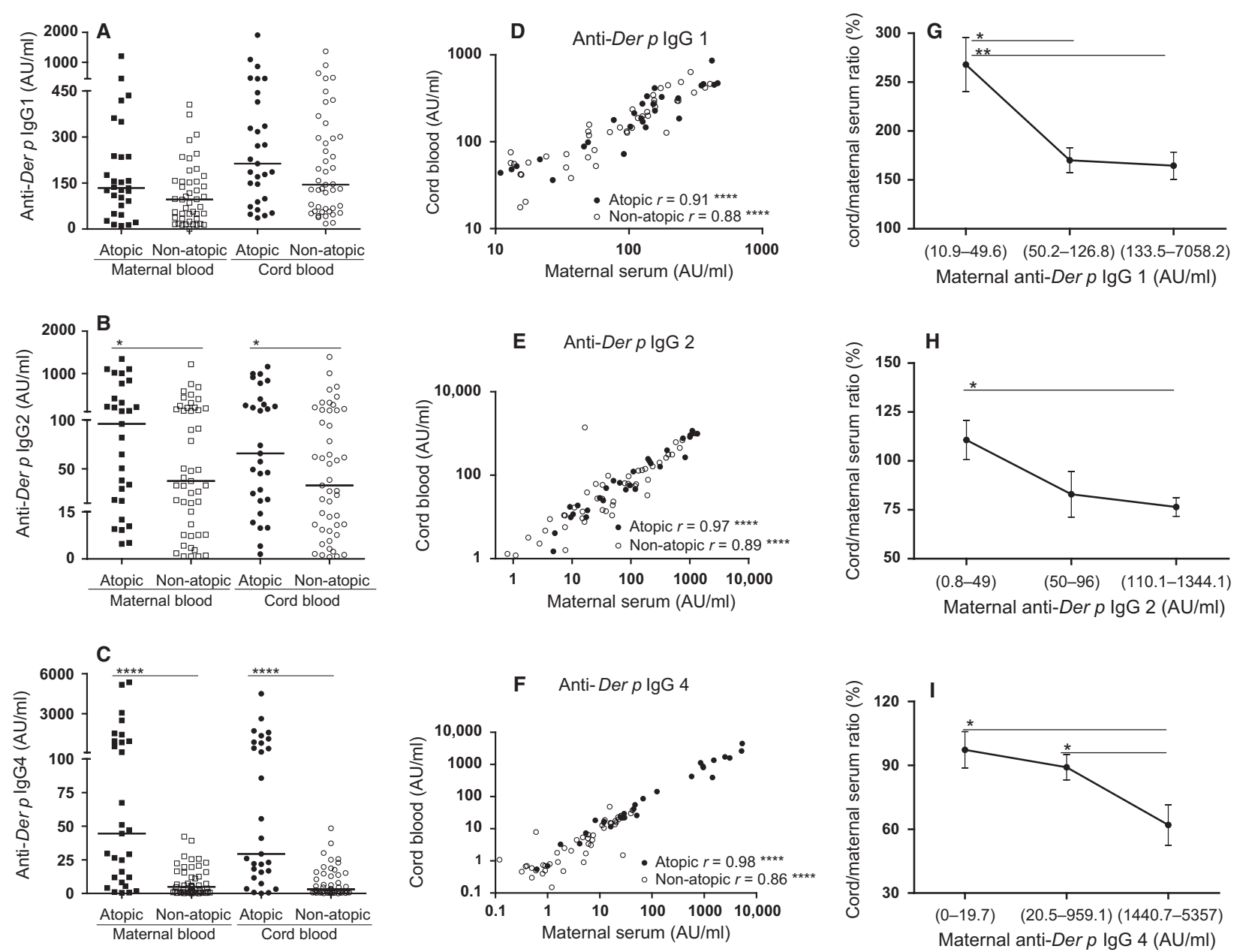

Figure 2 Der p-specific IgG1, IgG2 and IgG4 concentrations in maternal and cord blood. Specific IgG1, IgG2 and IgG4 levels were determined in paired maternal and cord blood samples. Data are compared according to maternal atopic status by Mann-Whitney test (A-C). Der p-specific IgG1, IgG2 and IgG4 concentrations obtained in cord blood are correlated with concentrations in respective maternal blood by Spearman test (D-F). Cord/maternal serum ratios of Der p-specific IgG1, IgG2 and IgG4 obtained at low, intermediate and high levels of respective maternal anti-Der $p$ IgG subclasses (G-I).

duration when maternal allergen-specific IgG is present in breast milk. The authors attributed the increased protection to the formation of allergen-IgG immune complexes that are easily transferred across the neonatal gut barrier compared to uncomplexed antigen and display tolerogenic properties [42].

Human studies also suggest an immunoregulatory role for in utero transfer of maternal IgG. A study by Glovsky et al. [43] analysed the effect of specific immunotherapy during pregnancy on allergic sensitization in children. Their data suggested that blocking antibodies induced by immunotherapy were transferred across the placenta and were responsible for decreased allergic sensitization in their children. Jenmalm and Bjorkstén [21] found that high concentration of $\mathrm{IgG}$ directed to inhaled allergens in cord blood was associated with reduced atopy in children. Another study showed a transient protective effect of placental transfer of maternal antibodies on allergic immune response [22]. The current study demonstrated a higher concentration of specific IgG4 and, to a lesser extent, of IgG2 in cord blood of neonates from atopic mothers compared to non-atopic mothers. Although we cannot conclude that these $\operatorname{IgG}$ subclasses exert an immunoregulatory role, a protective effect has previously been reported for IgG4 [44-46].

After delivery, breastfeeding maintains a strong interaction between the mother and her infant and in particular allows the continued transfer of maternal Ig. Secretory $\operatorname{IgA}$ is the predominant class of Ig found in human breast milk. This class of non-inflammatory Ig inhibits microbial colonization through decreased adherence of bacteria and viruses to mucosal surfaces and thereby protects against gut and respiratory infections in breastfed children [7]. IgA can also trap food antigens, leading to immune exclusion of dietary antigens by favouring degradation by pancreatic enzymes [47]. In addition to 

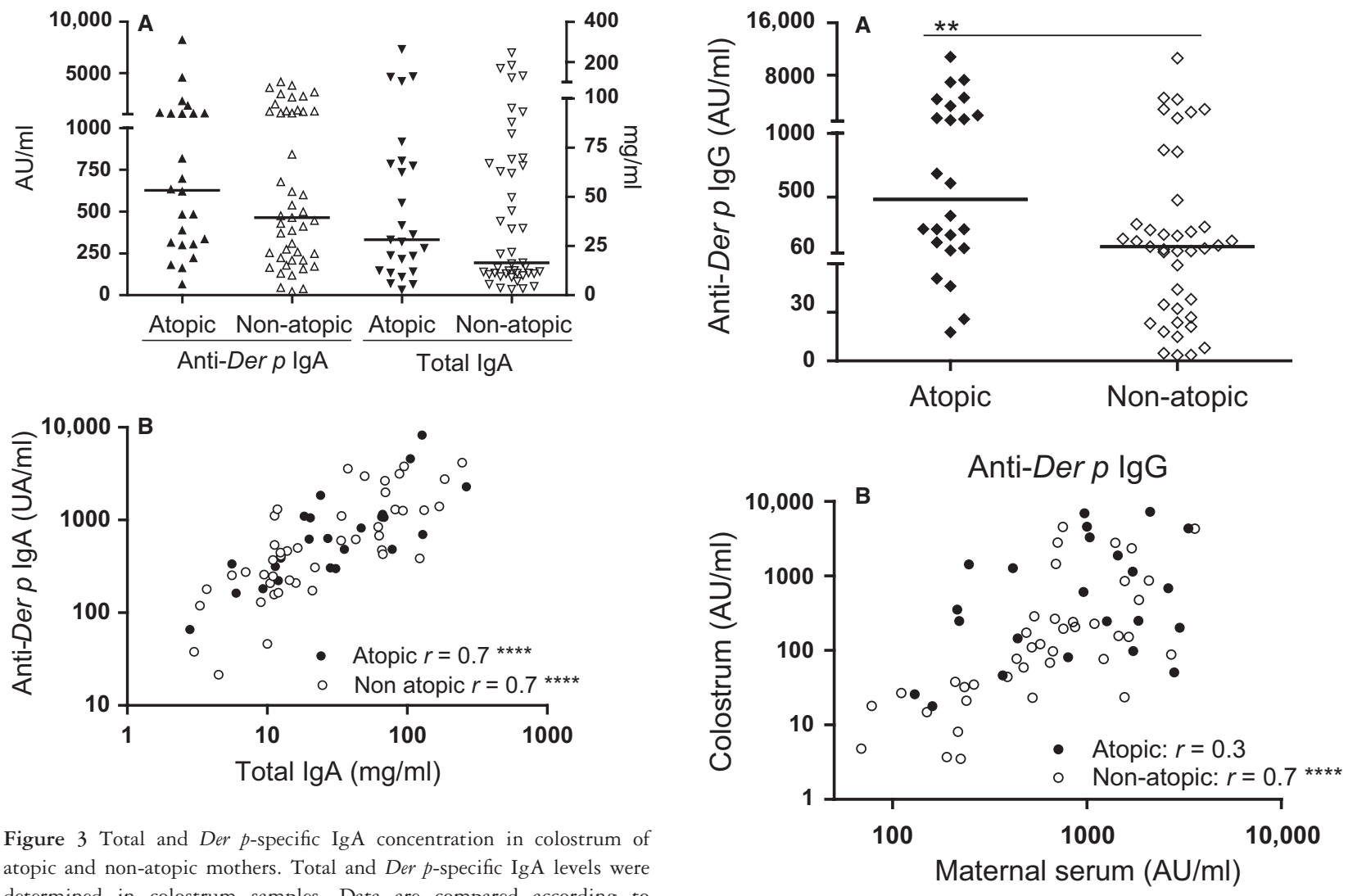

Figure 3 Total and Der p-specific IgA concentration in colostrum of atopic and non-atopic mothers. Total and Der p-specific IgA levels were determined in colostrum samples. Data are compared according to maternal atopic status by Mann-Whitney test. Total IgA concentration is expressed in $\mathrm{mg} / \mathrm{ml}$ (right $Y$-axis), and anti-Der $p \operatorname{IgA}$ concentration is expressed in $\mathrm{AU} / \mathrm{ml}$ (left $Y$-axis) (A). Der p-specific IgA concentrations are correlated with total $\operatorname{IgA}$ concentrations by Spearman test (B).

immune exclusion, $\operatorname{Ig} \mathrm{A}$ can exert immunoregulatory effects [17-20]. The epidemiological evidence of food allergy prevention by IgA [48-51] might be explained by these two mechanisms. As the majority of inhaled antigens reach the gut [52], the presence of milk-borne $\operatorname{Der}$-specific IgA may then protect the newborn from respiratory allergens as proposed for food allergens. Notably, we found anti-Der $p \operatorname{IgA}$ in all colostrum samples tested. The range of values was broad, and we did not observe significant differences in antibody concentrations between atopic and non-atopic mothers. One previous study assessed the presence of $\operatorname{IgA}$ to cat allergen in human breast milk from atopic and non-atopic mothers. This study also found a similar concentration of $\operatorname{IgA}$ in both groups [26]. The absence of an effect of atopy on IgA levels could be explained by the fact that IgA class switching depends mainly on the presence of TGF- $\beta$ [53]. In fact, we found similar levels of TGF- $\beta$ in colostrum of atopic and non-atopic mothers, and we observed that both total IgA and Der p-specific IgA levels correlated with TGF- $\beta$ levels in colostrum (Figure S1).

In addition to $\operatorname{IgA}$ specific for respiratory allergen, our study demonstrated, for the first time, the presence of Der p-specific IgG in colostrum. Der p-specific IgG con-

Figure $4 \mathrm{Der}$ p-specific IgG concentration in colostrum. Der p-specific IgG levels were determined in colostrum samples. Data are compared according to maternal atopic status by Mann-Whitney test (A). Concentrations obtained in colostrum are correlated with concentrations in respective maternal serum by Spearman test (B).

centrations were higher in colostrum from atopic mothers compared to non-atopic mothers, and colostrum levels correlated with maternal $\mathrm{IgE}$ serum levels. It is worth noting that colostrum Der p-specific IgG concentration correlated with maternal serum IgG levels in the nonatopic but not in the atopic group. IgG in colostrum could come from maternal serum, as supported by the observation that intravenous administration of $\mathrm{Ig}$ to immunodeficient mothers results in the presence of Ig in breast milk [54]. In addition, IgG maybe synthesized locally in the mammary gland. The latter mechanism may operate in the atopic group because there was no correlation between maternal serum and colostrum Der pspecific IgG levels in that group. Studies in rodents suggest that, as in the placenta, FcRn can be involved in IgG transfer across mammary gland epithelium [55]. Notably, in contrast to $\operatorname{Ig} A$ that stays in the gut lumen, anti-Der $p$ IgG can then be transferred to the neonate by FcRn expressed in the human proximal intestine [39, 56]. This continuous supply of IgG after delivery may be sufficient to maintain systemic levels in the neonate and allow protection from asthma when in utero-transferred 
antibodies have been degraded. In support of this hypothesis, a meta-analysis of prospective studies and a multidisciplinary review of studies performed between 1966 and 2000 concluded that breastfeeding protection from asthma was higher in the subgroup of children with a positive family history of asthma or atopy compared with children with no parental history of atopy [57, 58]. In the light of experimental data obtained in animal models, our work suggests that the higher concentration of Der p-specific IgG in colostrum from atopic mothers may contribute to the better protection afforded upon breastfeeding by atopic mothers.

\section{Conclusions}

Our study indicates that Der p-specific IgG can be found in both cord blood and colostrum and identifies maternal atopy as a critical factor for increased levels of allergenspecific IgG in these compartments. In addition, Der pspecific $\operatorname{IgA}$ is present in colostrum. Clinical studies will be necessary to assess whether $\operatorname{Der} p$-specific $\operatorname{IgG}$ and $\operatorname{IgA}$ protect the child from allergy as demonstrated in animal studies. In view of the increasing evidence from animal models and importance of neonatal prevention of allergy, this study would be a timely and necessary way to elucidate the role of allergen-specific Ig in early life and its effect on allergy development.

\section{Acknowledgment}

The authors thank Maternidade de Campinas Hospital, Prof. Maria Notomi Sato (Laboratory of Clinical and Experimental Allergy and Immunology, School of Medicine, University of São Paulo) for supplying us with antihuman IgG antibodies, Dr José Carlos Mori (IPI-ASAC, Brasil) for Der p purified extract, nurse Silvana S. Dalgé for her excellent assistance in the colostrum collection, Dr Meri Tulic and Dr Peter Newburger for critical reading of the manuscript, as well as the mothers who kindly agreed to participate in this study. We also acknowledge the State of São Paulo Research Foundation (FAPESP) for financial support: Grant 08/58825-7 to Antonio Condino-Neto, Grants 05/57593-7 and 08/51535-3 to Patricia Macchiaverni.

\section{References}

1 Masoli M, Fabian D, Holt S, Beasley R. The global burden of asthma: executive summary of the GINA Dissemination Committee report. Allergy 2004;59:469-78.

2 Boyle RJ, Tang ML. Can allergic diseases be prevented prenatally? Allergy 2006;61:1423-31.

3 Simister NE. Placental transport of immunoglobulin G. Vaccine 2003;21:3365-9.

4 Bonnelykke K, Pipper CB, Bisgaard H. Sensitization does not develop in utero. J Allergy Clin Immunol 2008;121:646-51.
5 Bonnelykke K, Pipper CB, Bisgaard H. Transfer of maternal IgE can be a common cause of increased $\mathrm{IgE}$ levels in cord blood. J Allergy Clin Immunol 2010;126:657-63.

6 Schroeder HW Jr, Cavacini L. Structure and function of immunoglobulins. J Allergy Clin Immunol 2010;125:S41-52.

7 Brandtzaeg P. Mucosal immunity: integration between mother and the breast-fed infant. Vaccine 2003;21:3382-8.

8 Hanson LA, Korotkova M, Haversen L et al. Breast-feeding, a complex support system for the offspring. Pediatr Int 2002; 44:347-52.

9 Jarrett EE, Hall E. IgE suppression by maternal IgG. Immunology 1983;48:49-58.

10 Seeger M, Thierse HJ, Lange $H$, Shaw L, Hansen $H$, Lemke $H$. Antigen-independent suppression of the $\mathrm{IgE}$ immune response to bee venom phospholipase A2 by maternally derived monoclonal IgG antibodies. Eur J Immunol 1998;28:2124-30.

11 Fusaro AE, Maciel M, Victor JR, Oliveira CR, Duarte AJ, Sato $\mathrm{MN}$. Influence of maternal murine immunization with Dermatophagoides pteronyssinus extract on the type I hypersensitivity response in offspring. Int Arch Allergy Immunol 2002;127:208-16.

12 Melkild I, Groeng EC, Leikvold RB, Granum B, Lovik M. Maternal allergen immunization during pregnancy in a mouse model reduces adult allergy-related antibody responses in the offspring. Clin Exp Allergy 2002;32:1370-6.

13 Uthoff H, Spenner A, Reckelkamm W et al. Critical role of preconceptional immunization for protective and nonpathological specific immunity in murine neonates. J Immunol 2003;171:3485-92.

14 Fusaro AE, Brito CA, Victor JR et al. Maternal-fetal interaction: preconception immunization in mice prevents neonatal sensitization induced by allergen exposure during pregnancy and breastfeeding. Immunology 2007;122:107-15.

15 Victor JR, Muniz BP, Fusaro AE et al. Maternal immunization with ovalbumin prevents neonatal allergy development and up-regulates inhibitory receptor FC gamma RIIB expression on B cells. BMC Immunol 2010;11:11.

16 Polte T, Hennig C, Hansen G. Allergy prevention starts before conception: maternofetal transfer of tolerance protects against the development of asthma. J Allergy Clin Immunol 2008;122:1022-30 e5.

17 Smits HH, Gloudemans AK, van Nimwegen $\mathrm{M}$ et al. Cholera toxin B suppresses allergic inflammation through induction of secretory IgA. Mucosal Immunol 2009;2:331-9.

18 Favre L, Spertini F, Corthesy B. Secretory IgA possesses intrinsic modulatory properties stimulating mucosal and systemic immune responses. J Immunol 2005;175:2793-800.

19 Sletten GB, Halvorsen R, Egaas E, Halstensen TS. Casein-specific immunoglobulins in cow's milk allergic patient subgroups reveal a shift to IgA dominance in tolerant patients. Pediatr Allergy Immunol 2007;18:71-80.

20 Pilette C, Durham SR, Vaerman JP, Sibille Y. Mucosal immunity in asthma and chronic obstructive pulmonary disease: a role for immunoglobulin A? Proc Am Thorac Soc 2004;1:125-35.

21 Jenmalm MC, Bjorksten B. Cord blood levels of immunoglobulin $\mathrm{G}$ subclass antibodies to food and inhalant allergens in relation to maternal atopy and the development of atopic disease during the first 8 years of life. Clin Exp Allergy 2000;30:34-40.

22 Prescott SL, Holt PG, Jenmalm M, Bjorksten B. Effects of maternal allergen-specific IgG in cord blood on early postnatal development of allergen-specific T-cell immunity. Allergy 2000;55:470-5.

23 Juto P, Holm S. Gliadin-specific and cow's milk protein-specific IgA in human milk. J Pediatr Gastroenterol Nutr 1992;15:159-62.

24 Chirdo FG, Rumbo M, Anon MC, Fossati CA. Presence of high levels of non-degraded gliadin in breast milk from healthy mothers. Scand J Gastroenterol 1998;33:1186-92.

25 Rumbo M, Chirdo FG, Anon MC, Fossati CA. Detection and characterization of antibodies specific to food antigens (gliadin, ovalbu- 
min and beta-lactoglobulin) in human serum, saliva, colostrum and milk. Clin Exp Immunol 1998;112:453-8.

26 Casas R, Bottcher MF, Duchen K, Bjorksten B. Detection of IgA antibodies to cat, beta-lactoglobulin, and ovalbumin allergens in human milk. J Allergy Clin Immunol 2000;105:1236-40.

27 Arlian LG, Platts-Mills TA. The biology of dust mites and the remediation of mite allergens in allergic disease. $J$ Allergy Clin Immunol 2001;107:S406-13.

28 Arlian LG, Morgan MS. Biology, ecology, and prevalence of dust mites. Immunol Allergy Clin North Am 2003;23:443-68.

29 Arbes SJ Jr, Cohn RD, Yin M et al. House dust mite allergen in US beds: results from the First National Survey of Lead and Allergens in Housing. J Allergy Clin Immunol 2003;111:408-14.

30 Zock JP, Heinrich J, Jarvis D et al. Distribution and determinants of house dust mite allergens in Europe: the European Community Respiratory Health Survey II. J Allergy Clin Immunol 2006;118:682-90.

31 Johansson SGO, ed. IgE Antibodies and the Pharmacia CAP System in Allergy Diagnosis. Lidköping: Landströms: Ed. Clinical Workshop, 1988. ISBN: 91-973440-0-1.

32 Nagao AT, Friedlander-Del Nero D, Arslanian C, Carneiro-Sampaio MM. Elevated levels and different repertoire profile of colostral antiLPS antibodies may have a significant role in compensating newborn immunity. Scand J Immunol 2001;53:602-9.

33 Platts-Mills TA, Erwin EA, Allison AB et al. The relevance of maternal immune responses to inhalant allergens to maternal symptoms, passive transfer to the infant, and development of antibodies in the first 2 years of life. J Allergy Clin Immunol 2003;111:123-30.

34 Jenmalm MC, Holt PG, Bjorksten B. Maternal influence on IgG subclass antibodies to Bet $\mathrm{v} 1$ during the first 18 months of life as detected with a sensitive ELISA. Int Arch Allergy Immunol 1997;114:175-84.

35 de Oliveira CH, Binotti RS, Muniz JR, dos Santos JC, do Prado AP, de Pinho AJ Jr. Comparison of house dust mites found on different mattress surfaces. Ann Allergy Asthma Immunol 2003;91:559-62.

36 Hansen LG, Halken S, Host A, Moller K, Osterballe O. Prediction of allergy from family history and cord blood IgE levels. A followup at the age of 5 years. Cord blood IgE. IV. Pediatr Allergy Immunol 1993;4:34-40.

37 Odelram H, Bjorksten B, Leander E, Kjellman NI. Predictors of atopy in newborn babies. Allergy 1995;50:585-92.

38 Edenharter G, Bergmann RL, Bergmann KE et al. Cord blood-IgE as risk factor and predictor for atopic diseases. Clin Exp Allergy 1998;28:671-8.

39 Roopenian DC, Akilesh S. FcRn: the neonatal Fc receptor comes of age. Nat Rev Immunol 2007;7:715-25.

40 Benlounes N, Chedid R, Thuillier F, Desjeux JF, Rousselet F, Heyman M. Intestinal transport and processing of immunoglobulin G in the neonatal and adult rat. Biol Neonate 1995;67:254-63.

41 Strait RT, Morris SC, Finkelman FD. IgG-blocking antibodies inhibit IgE-mediated anaphylaxis in vivo through both antigen interception and Fc gamma RIIb cross-linking. $J$ Clin Invest 2006;116:833-41.

42 Mosconi E, Rekima A, Seitz-Polski B et al. Breast milk immune complexes are potent inducers of oral tolerance in neonates and prevent asthma development. Mucosal Immunol 2010;3:461-74.

43 Glovsky MM, Ghekiere L, Rejzek E. Effect of maternal immunotherapy on immediate skin test reactivity, specific rye I IgG and $\mathrm{IgE}$ antibody, and total $\mathrm{IgE}$ of the children. Ann Allergy 1991;67:21-4.

44 Aalberse RC, Stapel SO, Schuurman J, Rispens T. Immunoglobulin G4: an odd antibody. Clin Exp Allergy 2009;39:469-77.

45 Ruiter B, Knol EF, van Neerven RJ et al. Maintenance of tolerance to cow's milk in atopic individuals is characterized by high levels of specific immunoglobulin G4. Clin Exp Allergy 2007;37:1103-10.
46 Frew AJ. Allergen immunotherapy. J Allergy Clin Immunol 2010;125:S306-13.

47 Brandtzaeg PE. Current understanding of gastrointestinal immunoregulation and its relation to food allergy. Ann N Y Acad Sci 2002;964:13-45.

48 Janzi M, Kull I, Sjoberg R et al. Selective IgA deficiency in early life: association to infections and allergic diseases during childhood. Clin Immunol 2009;133:78-85.

49 Savilahti E, Tainio VM, Salmenpera L et al. Low colostral IgA associated with cow's milk allergy. Acta Paediatr Scand 1991;80:1207-13.

50 Calbi M, Giacchetti L. Low breast milk IgA and high blood eosinophil count in breast-fed newborns determine higher risk for developing atopic eczema after an 18-month follow-up. J Investig Allergol Clin Immunol 1998;8:161-4.

51 Savilahti E, Siltanen M, Kajosaari M, Vaarala O, Saarinen KM. IgA antibodies, TGF-beta1 and -beta2, and soluble CD14 in the colostrum and development of atopy by age 4. Pediatr Res 2005;58:1300-5.

52 Holt PG, Batty JE, Turner KJ. Inhibition of specific IgE responses in mice by pre-exposure to inhaled antigen. Immunology 1981;42:409-17.

53 van Vlasselaer P, Punnonen J, de Vries JE. Transforming growth factor-beta directs IgA switching in human B cells. J Immunol 1992;148:2062-7.

54 Palmeira P, Costa-Carvalho BT, Arslanian C, Pontes GN, Nagao AT, Carneiro-Sampaio MM. Transfer of antibodies across the placenta and in breast milk from mothers on intravenous immunoglobulin. Pediatr Allergy Immunol 2009;20:528-35.

55 Cianga P, Medesan C, Richardson JA, Ghetie V, Ward ES. Identification and function of neonatal Fc receptor in mammary gland of lactating mice. Eur J Immunol 1999;29:2515-23.

56 Israel EJ, Taylor S, Wu Z et al. Expression of the neonatal Fc receptor, FcRn, on human intestinal epithelial cells. Immunology 1997;92:69-74.

57 Gdalevich M, Mimouni D, Mimouni M. Breast-feeding and the risk of bronchial asthma in childhood: a systematic review with metaanalysis of prospective studies. J Pediatr 2001;139:261-6.

58 van Odijk J, Kull I, Borres MP et al. Breastfeeding and allergic disease: a multidisciplinary review of the literature (1966-2001) on the mode of early feeding in infancy and its impact on later atopic manifestations. Allergy 2003;58:833-43.

\section{Supporting Information}

Additional supporting information may be found in the online version of this article.

Figure S1 Colostrum IgA levels are correlated to colostrums TGF- $\beta$ levels in colostrum. TGF- $\beta$ levels were determined in colostrum samples by ELISA according to manufacturer instruction (Promega, CAT G 7591). Data obtained in colostrum from atopic and non atopic mothers are compared by Mann-Whitney test (a). TGF- $\beta$ concentrations obtained in colostrum are correlated with colostrum total IgA (b) and colostrum Der p-specific IgA (c) using Spearman test.

Please note: Wiley-Blackwell are not responsible for the content or functionality of any supporting materials supplied by the authors. Any queries (other than missing material) should be directed to the corresponding author for the article. 


\section{APÊNCIDE B}

Macchiaverni P, Rekima A; Tulic MK, Verhasselt V. L'allaitement maternel peut-il prévenir les maladies allergiques parl'induction de tolérance orale? Possible prevention of allergic disease by breastfeeding induced oral tolerance. Revue Française d'Allergologie. 2012. in press 


\section{QUESTIONS À L'AUTEUR}

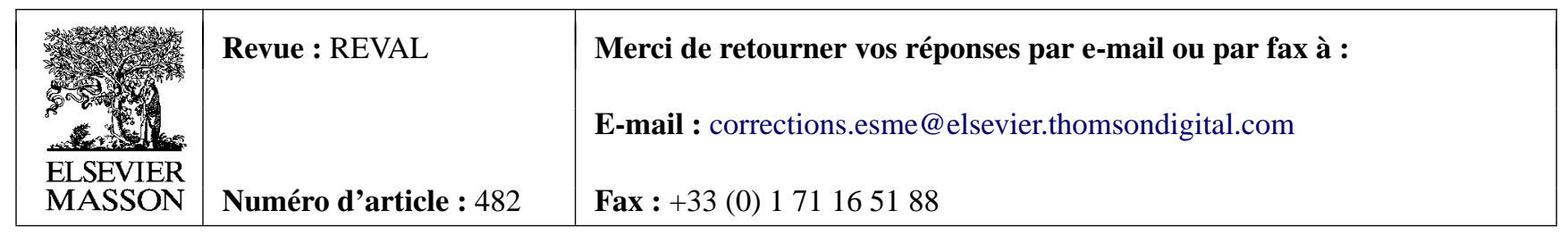

Cher auteur,

Vous trouverez ci-dessous les éventuelles questions et/ou remarques qui se sont présentées pendant la préparation de votre article. Elles sont également signalées dans l'épreuve par une lettre «Q $»$ suivie d'un numéro. Merci de vérifier soigneusement vos épreuves et de nous retourner vos corrections soit en annotant le PDF ci-joint, soit en les listant séparément.

Pour toute correction ou modification dans les figures, merci de consulter la page http://www.elsevier.com/artworkinstructions.

Articles de numéros spéciaux : merci d'ajouter (dans la liste et dans le corps du texte) la mention « dans ce numéro » pour toute référence à d'autres articles publiés dans ce numéro spécial.

Références non appelées : Références présentes dans la liste des références mais pas dans le corps de l'article - merci d'appeler chaque référence dans le texte ou de les supprimer de la liste.

Références manquantes : Les références ci-dessous se trouvaient dans le texte mais ne sont pas présentes dans la liste des références. Merci de compléter la liste ou de les supprimer du texte.

\begin{tabular}{|c|c|}
\hline $\begin{array}{l}\text { Emplacement } \\
\text { dans l'article }\end{array}$ & $\begin{array}{c}\text { Question / Remarque } \\
\text { Merci d'insérer votre réponse ou votre correction à la ligne correspondante dans l'épreuve }\end{array}$ \\
\hline$\frac{\mathrm{Q} 1}{\mathrm{Q} 2}$ & $\begin{array}{l}\text { Merci de vérifier que les prénoms et les noms ont été correctement identifiés. } \\
\text { Nous avons réorganisé cette partie en insérant des intertitres. Merci de vérifier. } \\
\text { Merci de nous transmettre la tomaison et les folios des références [32,54]. }\end{array}$ \\
\hline
\end{tabular}

\section{Utilisation des fichiers électroniques}

Si nous n'avons pas pu exploiter le fichier de votre article et/ou de vos figures, nous avons utilisé la méthode suivante : Scan de (ou de parties de) votre article
Ressaisie de (ou de parties de) votre article

Merci de votre collaboration. 


\title{
L'allaitement maternel peut-il prévenir les maladies allergiques par l'induction de tolérance orale ?
}

\section{Possible prevention of allergic disease by breastfeeding induced oral tolerance}

\author{
P. Macchiaverni ${ }^{\mathrm{a}}$, A. Rekima ${ }^{\mathrm{b}}$, M.K. Tulic ${ }^{\mathrm{c}}$, V. Verhasselt ${ }^{\mathrm{b}, *}$ \\ ${ }^{a}$ Department of Immunology, Institute of Biomedical Sciences, University of São Paulo, São Paulo, Brazil \\ ${ }^{\mathrm{b}}$ Inserm, EA 6302 «tolérance immunitaire », université de Nice Sophia-Antipolis, hôpital de l'Archet, route Saint-Antoine-de-Ginestière, \\ BP 3079, 06202 Nice cedex 03, France \\ ${ }^{\mathrm{c}}$ School of Pediatrics and Child Health, University of Western Australia, Perth, Australia
}

Reçu le 11 juillet 2012 ; accepté le 27 août 2012

\begin{abstract}
Résumé
Le système immunitaire du nouveau-né est soumis à un défi considérable devant à la fois faire face à une stimulation antigénique massive du fait de la colonisation microbienne de la peau et du tractus digestif ainsi que de l'exposition à une multitude d'antigènes environnementaux. Outre ses vertus nutritives et son impact sur la prévention des maladies infectieuses, le lait maternel pourrait contribuer à l'éducation du système immunitaire vers l'acceptation des antigènes du soi et de l'environnement inoffensifs. En effet, des études épidémiologiques rapportent un effet protecteur de l'allaitement vis-à-vis de maladies dues à un défaut de tolérance immunitaire, telles que le diabète de type 1, la maladie cœliaque et les allergies. Cependant, les données de la littérature sont controversées et les mécanismes peu identifiés. Dans cette revue, nous présenterons et discuterons les données qui suggèrent que l'allaitement pourrait exercer des effets protecteurs à l'égard des maladies allergiques par induction de tolérance immunitaire suite au transfert d'allergène dans le lait. Nous présenterons les facteurs requis pour conférer ce potentiel tolérogène au lait maternel. Une meilleure compréhension des mécanismes de tolérance en début de vie et de l'impact de la mère sur ce processus via l'allaitement devrait permettre de proposer de nouvelles stratégies de prévention des maladies allergiques.
\end{abstract}

(C) 2012 Publié par Elsevier Masson SAS.

Mots clés : Tolérance immunitaire ; Allaitement ; Nouveau-né ; Allergie ; Prévention primaire

\section{Abstract}

Neonatal immune system faces considerable challenges as it must cope with antigenic stimulus following gut and skin bacterial colonization, and exposure to numerous new environmental antigens while organs are developing requiring low inflammation to allow harmonious growth. In addition to its impact on child growth and prevention of infectious disease, breast-milk may help to educate the immune system towards acceptance of non "dangerous" antigens. Indeed, epidemiological studies report that breastfeeding protects from immune-mediated diseases such as allergy, celiac disease and Type-1 Diabetes. However, data are controversial and mechanisms unclear. Here we will present and discuss experimental data indicating that breastfeeding-induced protection may rely on immune tolerance induction in the breastfed child upon antigen transfer through maternal milk. The tolerogenic potential of breast milk depends on maternal exposure to common environmental and dietary antigens and the efficiency of antigen transfer across mammary epithelium. Induction of tolerance upon breast-milk mediated antigen transfer will also depend on the presence of immunomodulatory factors in breast-milk and of its impact on neonatal gut and immune system maturation. The better understanding of maternal influence on tolerance induction by antigen transfer through breast milk should allow the development of new strategies for prevention of immune mediated diseases.

(C) 2012 Published by Elsevier Masson SAS.

Keywords: Immune tolerance; Breast milk; Antigen; Neonate; Allergy; Primary prevention

* Auteur correspondant.

Adresse e-mail : verhasselt@unice.fr (V. Verhasselt).

1877-0320/\$ - see front matter (C) 2012 Publié par Elsevier Masson SAS.

http://dx.doi.org/10.1016/j.reval.2012.08.002 


\section{Introduction}

49

1.1.1. Allergènes du lait de vache. La présence de bêtaactoglobuline a été amplement étudiée [8-16]. Il s'agit d'une protéine de $36 \mathrm{kDa}$ résistante à la dégradation acide et enzymatique, ce qui suggère qu'elle serait mieux absorbée que les autres protéines du lait. Il existe une grande variabilité inter- et intra-individuelle des taux de bêta-lactoglobuline et seulement la moitié des femmes qui consomment du lait de vache la sécrète dans leur lait. Les taux de bêta-lactoglobuline dans le lait maternel varient d'indétectable à $800 \mathrm{ng} / \mathrm{mL}$ avec des taux moyens rapportés de 1 à $10 \mathrm{ng} / \mathrm{mL}$. Le pic de concentration de bêta-lactoglobuline après ingestion de lait de vache est à une à 12 heures et l'on retrouve la protéine jusqu'à neuf jours après [9].

2.1.1.2. Allergènes d'œuf de poule. Tant l'ovalbumine (OVA), une protéine de $44 \mathrm{kDa}$ qui représente $64 \%$ des protéines totales de l'œuf que l'ovomucoïde, une protéine de $28 \mathrm{kDa}$ considérée comme l'allergène majeur de l'œuf sont retrouvés dans le lait. L'OVA est présente dans $35 \%$ des laits à des taux variant de 0,1 à $1200 \mathrm{ng} / \mathrm{mL}$ avec une valeur médiane de $1 \mathrm{ng} / \mathrm{mL}$ [17]. Après consommation d'un œuf, les taux d'OVA dans le lait varient de 0,1 à $11,5 \mathrm{ng} / \mathrm{mL}$ et sont détectés dans 59 à $74 \%$ des laits [11,17-20]. Étonnement, même après trois semaines d'administration quotidienne d'œuf, un quart des femmes n'excrèteront jamais d'œuf dans leur lait [18]. L'ovomucoïde est détectée dans $30 \%$ des laits avec un taux maximum de $37 \mathrm{ng} / \mathrm{mL}$ [21].

2.1.1.3. Allergènes d'arachide. Les deux allergènes majeurs de l'arachide, Ara h 1 and Ara h 2, de poids moléculaires de $66 \mathrm{kDa}$ et $17 \mathrm{kDa}$ respectivement, sont détectés dans le lait maternel. On les retrouve une à deux heures après ingestion, avec un pic après six heures et une élimination rapide ensuite. Après l'ingestion de $50 \mathrm{~g}$ cacahuètes, ces allergènes sont retrouvés dans $50 \%$ des cas à des taux allant de 120 à 430 ng/ $\mathrm{mL}[22]$.

2.1.1.4. Protéine de farine de blé. La gliadine qui peut être responsable chez certains individus du développement de la maladie cœliaque mais aussi d'allergie au blé est retrouvée dans la majorité des laits. Le groupe de Chirdo a rapporté des taux de gliadine allant de 5 à $1200 \mathrm{ng} / \mathrm{mL}$ avec une valeur moyenne de $178 \mathrm{ng} / \mathrm{mL}$ dans les laits matures et des taux allant jusqu'à $9000 \mathrm{ng} / \mathrm{mL}$ dans les colostrums [23].

\subsubsection{Antigènes respiratoires}

Nous avons démontré dans un modèle murin que les antigènes respiratoires pouvaient être retrouvés dans le lait maternel à des taux comparables à ceux décrits pour les antigènes alimentaires dans le lait humain [24,25]. Nous avons retrouvé l'OVA inhalée par les mères dans le lait, soit sous forme libre, soit associé à des $\operatorname{IgG}$ et des $\operatorname{Ig} \mathrm{A}$ lorsque les mères avaient été préalablement immunisées à l'encontre de l'OVA.

La présence d'antigène respiratoire s'explique aisément si l'on sait que la quasi-totalité des antigènes inhalés se retrouvent dans le tractus digestif [26,27]. Les antigènes inhalés sont en effet, soit capturés au niveau nasal et ensuite déglutis, soit déposés au niveau pulmonaire et rapatriés vers le tractus digestif via l'escalator muco-cilié. Ils suivent ensuite le même trajet que les antigènes alimentaires vers la glande mammaire. Seule une petite fraction des antigènes respiratoires rejoindrait directement la circulation sanguine via l'épithélium alvéolocapillaire [28,29] et ensuite la glande mammaire.

Chez l'homme, Casas et Bjorksten ont décrit la présence de l'allergène de chat Fel d 1 associé à des $\mathrm{IgG}$ dans le sérum maternel [30]. Der p1, l'allergène majeur des acariens a 
également été retrouvé dans le sang maternel [31] et les anticorps de type $\operatorname{IgG}$ et $\operatorname{IgA}$ spécifiques des allergènes d'acariens ont été retrouvés dans le sérum de mères atopiques et non atopiques [32]. Ces données suggèrent fortement que dans le lait humain aussi des allergènes repiratoires pourraient être retrouvés libres ou associés à des anticorps. Aussi, nous avons récemment pu détecter l'allergène Der $\mathrm{p} 1$ dans les colostrums et lait humain à des taux allant de 10 à 1000 pg/mL (nos données non publiées).

\subsection{Différences d'exposition antigénique chez le jeune enfant qui est allaité et celui qui ne l'est pas}

Au vu des données décrites ci-dessus, on peut conclure que l'enfant allaité aura une exposition antigénique qualitativement et quantitativement très différence de l'enfant non allaité. En effet, l'enfant nourri par des laits artificiels recevra exclusivement des antigènes de lait de vache en haute quantité (de l'ordre du gramme par jour) alors que l'enfant allaité recevra par voie orale une multitude d'antigènes dérivés de l'alimentation maternelle et vraisemblablement aussi inhalés par la mère. Par rapport à une exposition alimentaire directe, ces antigènes se retrouvent en quantité 1000 fois plus basse, condition favorables à l'induction de tolérance orale [33]. De plus, comme discuté ci-dessous, le lait maternel contient des facteurs qui peuvent affecter considérablement l'induction de tolérance orale et qui sont absents pour la plupart des laits artificiels notamment suite aux traitements thermiques qu'ils subissent.

\subsection{Quels sont les facteurs qui conditionnent la présence d'antigène dans le lait maternel?}

Hormis nos données obtenues dans un modèle murin, il n' y a pas d'étude concernant les facteurs qui gouvernent les taux d'allergènes respiratoires dans le lait ; néanmoins, au vu de ce que nous avons détaillé plus haut, il est fort probable que ce soit les mêmes facteurs que ceux requis pour les antigènes alimentaires.

Pour ceux-ci, on peut proposer que l'alimentation maternelle (ou exposition par voie respiratoire pour les allergènes respiratoires), la digestion, le passage au travers la muqueuse digestive maternelle, l'élimination par le système réticuloendothélial et le transfert vers la glande mammaires sont impliqués.

La plupart des études ne montrent pas de corrélation directe entre la consommation d'un antigène alimentaire et sa présence dans le lait $[10,16-18,20]$. Le statut atopique de la mère ne semble également pas associé à des taux plus hauts ou bas d'antigènes dans le lait $[12,17]$. Sorva et al. n'ont pas trouvé de corrélation entre la perméabilité intestinale à des molécules de haut poids moléculaire (PEG 3000) et les taux de bêtalactoglobuline dans le lait maternel [9]. L'association de l'antigène à des IgG spécifiques pourrait favoriser le passage de l'antigène grâce à l'utilisation d'un transfert protégé via le Fc récepteur néonatal $(\mathrm{FcRn})$ exprimé au niveau de l'épithélium digestif [34] ; alors que l'association de l'antigène à des $\operatorname{Ig} \mathrm{A}$ spécifiques préviendrait son absorption [35]. Les mécanismes de transfert de l'antigène au travers la glande mammaire sont peu étudiés. Un parallélisme hypothétique peut être fait avec le transfert au travers la barrière intestinale suggérant que des mécanismes para- et trans-cellulaires agiraient [36]. Certaines études ont utilisé le rapport sodium/potassium comme témoin de la perméabilité paracellulaire de la glande mammaire [37,38] ; cependant, aucune n'a analysé à l'heure actuelle s'il y avait une corrélation entre perméabilité paracellulaire et transfert d'antigène. Le FcRn qui, comme nous l'avons décrit plus haut est exprimé au niveau de l'épithélium intestinal, l'est aussi au niveau de la glande mammaire $[39,40]$ et ainsi permettrait le transfert de complexes immuns circulants IgGantigènes communément retrouvés chez les individus atopiques ou non $[11,30,41,42]$.

La présence de complexes immuns IgA-antigènes dans le lait maternel a été décrite pour des antigènes alimentaires, tels que la gliadine et l'ovomucoïde [21,23]. Dans ce cas, les complexes immuns sont très probablement formés localement étant donné que la synthèse des IgA secrétoires a lieu au niveau de la glande mammaire elle-même [2].

Enfin, une autre voie possible de transfert protégé d'antigène vers le lait maternel serait les exosomes, des nanovésicules produites par des cellules du système immunitaire mais aussi l'épithélium intestinal. Dans ce dernier cas, il a été décrit que les exosomes permettaient un transfert protégé des antigens luminaux vers la lamina propria sous une forme immunogénique ou tolérogénique [43,44]. Aussi, de façon très intéressantes, des exosomes sont retrouvés dans le lait maternel [45] ; leur origine est à ce jour inconnue et pourrait être issus des cellules épithéliales mammaires ou les leucocytes du lait.

\subsection{Cofacteurs tolérogènes du lait maternel}

\subsubsection{Cytokines tolérogènes}

2.4.1.1. TGF-bêta. Le TGF-bêta est une cytokine essentielle dans l'induction et le maintien de tolérance [46]. La présence de faible concentration de TGF-bêta dans l'intestin du nouveau-né contrastant avec les hauts taux de TGF-bêta du lait maternel [47] illustre à nouveau la complémentarité mère-enfant apportée par l'allaitement. Les travaux de Pentilla réalisés chez le rat ont démontré le rôle régulateur du TGF-bêta du lait maternel tant au niveau de l'inflammation intestinale qu'au niveau de la prévention des allergies [48,49]. Nous avons observé que l'induction de tolérance par transfert d'antigène via le lait maternel et la prévention d'allergie étaient totalement abolies en cas de déplétion du lait maternel en TGF-bêta [25].

Les études chez l'homme sont également en faveur d'un effet protecteur du TGF-bêta du lait maternel vis-à-vis du développement de maladies allergiques [50]. Les facteurs qui conditionnent les taux de TGF-bêta dans le lait sont peu identifiés. Nous avons observé des taux extrêmement reproductibles de TGF-bêta dans les lait de souris, qu'elles soient de fond génétique différents, allergiques ou non, immunocompétentes ou immuno-déficientes. (Verhasselt, non publié). Chez l'homme, les taux de TGF-bêta semblent beaucoup plus variables sans qu'aient été identifiés les causes de ces 
variations ; la prise de probiotiques quant à elle augmenterait les taux de TGF-bêta dans le lait [51,52].

2.4.1.2. Autres cytokines. Outre le TGF-bêta, d'autres cytokines anti-inflammatoires, telles que l'IL-10 et pro-inflammatoire, telles que le TNF-a, IL-6, IL-1, IFN-g, IL-4, Il-5, IL-13, ont été retrouvées à des taux variables dans le lait maternel [53]. Dès lors, la balance pro- ou anti-inflammatoire de ces cytokines influera certainement sur le potentiel tolérogène du lait maternel.

\subsubsection{Anticorps maternels}

Outre la présence bien documentée d'IgA anti-microbienne dans le lait maternel, on retrouve des IgA dirigées contre les antigènes alimentaires [21,23], ainsi que respiratoires [32]. De plus, des IgG anti-allergène respiratoire [32] et alimentaire (nos données non publiées) sont retrouvés dans le lait. Dans un modèle murin, nous avons observé que la présence d'IgG, et non des $\operatorname{IgA}$, spécifiques de l'allergène était un puissant potentiateur de l'induction de tolérance suite au passage d'antigène via le lait. Nous avons pu démontré que cet effet était lié à un transport accru de l'antigène au travers la muqueuse digestive via le FcRn [24,34] ainsi qu'aux propriétés tolérogènes intrinsèques des complexes immuns IgGallergènes du lait maternel [24].

Le haut rapport IgG/antigen et la glycosylation des anticorps du lait maternel pourraient contribuer à cet effet tolérogène [54-57].

\subsubsection{Autres composés potentiellement protecteurs du lait maternels}

Le rapport entre les taux d'acides gras n- 6 versus n- 3 dans le régime alimentaire maternel durant la période d'allaitement influence l'efficacité d'induction de tolérance suite au transfert d'antigène par le lait chez le rat [58]. D'autres molécules immuno-régulatrices sont retrouvées dans le lait et pourraient influencer l'induction de tolérance, telles que l'ostéopontine [59,60], la vitamine A [61], la vitamine D, les glucocorticoïdes [62].

Le lait maternel peut également affecter l'induction de tolérance orale par un effet sur la maturation de la barrière digestive. En effet, le colostrum et dans une moindre mesure le lait mature contient de nombreuses molécules qui stimulent la maturation de la barrière intestinale [63]. Parmi celle-ci, l'epidermal growth factor (EGF) a été beaucoup étudié par sa capacité de prévenir l'entérocolite nécrosante [64]. D'autres facteurs, tels que l'erythropoetin, l'insulin-like growth factor, l'hepatocyte growth factor, le basic fibroblast growth factors ou encore le TGF-bêta agissent de concert pour induire le développement harmonieux de l'intestin. Cette maturation de l'intestin est associée à une diminution de la perméabilité intestinale, ce qui laisse suggérer un impact sur l'induction de tolérance orale [36].

Enfin, il semble actuellement de plus en plus évident que le microbiote intestinal est déterminant pour la maturation du système immunitaire de l'enfant et dès lors sa susceptibilité à l'induction de tolérance [65-67]. Aussi, l'impact de l'allaite- ment maternel via la présence de prébiotiques, de molécules anti-microbienne, telles que lactoferrine, lysozyme, IgA, sur la microbiote intestinale de l'enfant fait l'objet de nombreuses études mais que nous en détaillerons pas ici [68].

\section{5. Évidences chez l'homme et l'animal que l'allaitement peut prévenir les allergies par induction de tolérance orale}

La prévention des allergies par l'allaitement maternel a fait l'objet de nombreuses études résumées dans les très bonnes revues de Kramer, Greer et al. et Zeiger [69-71]. Une analyse multidisciplinaire de la littérature a retenu 56 publications publiées entre 1966 et 2001 : la moitié des études constatait que le fait d'allaiter durant au moins trois mois permettait la réduction du développement de dermatite atopique et d'asthme et ce, surtout si les enfants avaient une histoire familiale d'allergies [72]. Une meta-analyse d'études épidémiologiques a conclu que le fait d'allaiter protégeait et que le taux de protection était plus élevé dans le sous-groupe d'enfants avec une histoire familiale d'asthme [73]. Deux études sur des cohortes de 4089 [74] et 3115 enfants [75] ont démontré que l'allaitement protégeait mais cette fois sans impact du statut allergique des parents sur l'effet protecteur. Enfin, dans une étude de 1200 enfants, le fait d'allaiter ne protégeait pas contre le développement d'asthme et semblait même augmenter le risque d'asthme chez les enfants avec une histoire parentale d'allergie [76]. L'hétérogénéité des résultats pourrait être le reflet de différences méthodologiques mais aussi traduire le fait que les mécanismes qui sous-tendent la protection par l'allaitement ne sont pas bien connus et que dès lors certaines variables ne sont pas prises en compte dans l'analyse. Aussi, peu/pas d'études ont testé l'hypothèse que l'allaitement serait protecteur s'il remplit les conditions nécessaires à l'établissement de tolérance orale : présence de l'allergène et facteurs tolérogènes. À l'inverse, de nombreuses études ont testé si l'éviction d'un allergène durant l'allaitement pouvait prévenir les allergies partant que, chez l'adulte, l'éviction est classiquement adoptée pour éviter les manifestations allergiques. Les résultats de ces études démontrent qu'aucun bénéfice à long terme ne pouvait être attendu par cette approche [70,71,77-81]. Dans l'interprétation des études sur l'éviction ou à l'inverse l'exposition de l'antigène durant l'allaitement, il est crucial de déterminer les taux de l'antigène dans le lait au vu des données que nous avons résumées ci-dessus et qui démontrent l'absence de corrélation entre la consommation d'un antigène alimentaire et sa concentration dans le lait. Cela n'a cependant pas été réalisé. Enfin, les cas décrits d'allergie aux protéines du lait de vache chez les enfants exclusivement allaité pourraient remettre en question l'induction de tolérance par le lait maternel. Néanmoins, ces cas sont, d'une part, extrêmement rares (moins de 0,5\% comparativement aux 3 à $5 \%$ chez les enfants nourris au lait de vache) $[8,9,13]$ et, d'autre part, dans ces cas, il n'est pas démontré que la sensibilisation allergique a eu lieu par la voie du lait maternel. En effet, certains travaux démontrent que la sensibilisation allergique à des antigènes alimentaires pourrait avoir lieu par contact cutané 
avec des particules aérosolisées d'antigènes alimentaires [82,83].

Les études chez l'animal quant à elles ont clairement démontré que le passage d'antigène via le lait maternel prévenait l'induction de réponses immunitaires effectrices spécifiques de l'antigène transféré [24,25,58,84-87] ainsi que le développement de maladies allergiques [24,25,88,89]. Nos travaux ont démontré que les souris exposées par voie orale ou respiratoire à l'OVA pendant l'allaitement étaient protégées du développement d'asthme [24,25] et de diarrhée allergique (nos données non publiées) et ce, dans diverses souches génétiques de souris. La présence d'OVA seule dans le lait était insuffisante pour conférer la protection et la présente conjointe de TGF-bêta et/ou d'IgG anti-OVA était requise. Comme discuté plus haut, l'effet le plus marquant dans la potentialisation de la tolérance a été observé avec les IgG anti-OVA induisant une protection quasi totale et de longue durée, médiée par des lymphocytes T régulateurs exprimant la molécule FOXP3. Actuellement, nous nous efforçons de déterminer si le transfert via le lait d'allergènes autres que l'OVA, tels que les allergènes d'acariens ou de lait de vache sont également capables d'induire de la tolérance chez la souris. Dans des cohortes mères-enfants, nous vérifions si nos observations faites chez la souris sont transposables à l'homme.

\section{Conclusions}

Le lait maternel apporte au jeune enfant à la fois son alimentation, une immunité passive, des facteurs de croissance et de multiples composés qui influencent activement le développement de son système immunitaire. Les observations faites chez l'animal démontrent que le transfert d'antigènes alimentaires et respiratoires via le lait maternel peut contribuer au développement de tolérance immunitaire et la prévention des allergies sous réserve de la présence conjointe dans le lait de facteurs tolérogènes. Chaque lait pourra dès lors avoir un potentiel tolérogène différent qui dépendra de l'exposition maternelle aux allergènes, la perméabilité de la glande mammaire, le statut immunitaire de la mère, la balance de molécules tolérogènes et pro-inflammatoire dans le lait, la présence de facteurs de maturation du tractus digestif et l'impact du lait sur le microbiote de l'enfant. Une meilleure compréhension des facteurs qui conditionnent le potentiel tolérogène du lait maternel devrait permettre de développer de nouvelles stratégies de prévention primaire des maladies allergiques.

\section{Déclaration d'intérêts}

Les auteurs déclarent ne pas avoir de conflits d'intérêts en relation avec cet article.

\section{Remerciements}

La réalisation des expériences qui a permis l'écriture de cet article a reçu le soutien financier de l'Inserm, la Société française d'allergologie, l'Agence nationale de la recherche, la
Fondation recherche en santé respiratoire, la Fondation Princesse Grace et la Foundation for Research Support of the State of São Paulo - FAPESP.

\section{Références}

[1] Labbok MH, Clark D, Goldman AS. Breastfeeding: maintaining an irreplaceable immunological resource. Nat Rev Immunol 2004;4(7):565-72.

[2] Brandtzaeg P. Mucosal immunity: integration between mother and the breast-fed infant. Vaccine 2003;21(24):3382-8.

[3] Malcova $\mathrm{H}$, et al. Absence of breast-feeding is associated with the risk of type 1 diabetes: a case-control study in a population with rapidly increasing incidence. Eur J Pediatr 2006;165(2):114-9.

[4] Holmberg H, et al. Short duration of breast-feeding as a risk-factor for beta-cell autoantibodies in 5-year-old children from the general population. Br J Nutr 2007;97(1):111-6.

[5] Akobeng AK, et al. Effect of breast-feeding on risk of coeliac disease: a systematic review and meta-analysis of observational studies. Arch Dis Child 2006;91(1):39-43.

[6] Campbell Jr DA, et al. Breast feeding and maternal-donor renal allografts. Possibly the original donor-specific transfusion. Transplantation 1984;37(4):340-4.

[7] Burlingham WJ, et al. The effect of tolerance to noninherited maternal HLA antigens on the survival of renal transplants from sibling donors. N Engl J Med 1998;339(23):1657-64.

[8] Denis M, Loras-Duclaux I, Lachaux A. Cow's milk protein allergy through human milk. Arch Pediatr 2012;19(3):305-12.

[9] Sorva R, Makinen-Kiljunen S, Juntunen-Backman K. Beta-lactoglobulin secretion in human milk varies widely after cow's milk ingestion in mothers of infants with cow's milk allergy. J Allergy Clin Immunol 1994;93(4):787-92.

[10] Fukushima Y, et al. Consumption of cow milk and egg by lactating women and the presence of beta-lactoglobulin and ovalbumin in breast milk. Am J Clin Nutr 1997;65(1):30-5.

[11] Kilshaw PJ, Cant AJ. The passage of maternal dietary proteins into human breast milk. Int Arch Allergy Appl Immunol 1984;75(1):8-15.

[12] Host A, et al. Bovine beta-lactoglobulin in human milk from atopic and non-atopic mothers. Relationship to maternal intake of homogenized and unhomogenized milk. Clin Exp Allergy 1990;20(4):383-7.

[13] Host A, Husby S, Osterballe O. A prospective study of cow's milk allergy in exclusively breast-fed infants. Incidence, pathogenetic role of early inadvertent exposure to cow's milk formula, and characterization of bovine milk protein in human milk. Acta Paediatr Scand 1988;77(5):663-70.

[14] Jakobsson I, et al. Dietary bovine beta-lactoglobulin is transferred to human milk. Acta Paediatr Scand 1985;74(3):342-5.

[15] Machtinger S, Moss R. Cow's milk allergy in breast-fed infants: the role of allergen and maternal secretory IgA antibody. J Allergy Clin Immunol 1986;77(2):341-7.

[16] Axelsson I, et al. Bovine beta-lactoglobulin in the human milk. A longitudinal study during the whole lactation period. Acta Paediatr Scand 1986;75(5):702-7.

[17] Vance GH, et al. Exposure of the fetus and infant to hens' egg ovalbumin via the placenta and breast milk in relation to maternal intake of dietary egg. Clin Exp Allergy 2005;35(10):1318-26.

[18] Palmer DJ, Gold MS, Makrides M. Effect of maternal egg consumption on breast milk ovalbumin concentration. Clin Exp Allergy 2008;38(7):118691.

[19] Cant A, Marsden RA, Kilshaw PJ. Egg and cows' milk hypersensitivity in exclusively breast fed infants with eczema, and detection of egg protein in breast milk. Br Med J (Clin Res Ed) 1985;291(6500):932-5.

[20] Palmer DJ, Gold MS, Makrides M. Effect of cooked and raw egg consumption on ovalbumin content of human milk: a randomized, double-blind, cross-over trial. Clin Exp Allergy 2005;35(2):173-8.

[21] Hirose J, et al. Occurrence of the major food allergen, ovomucoid, in human breast milk as an immune complex. Biosci Biotechnol Biochem 2001;65(6):1438-40. 
[22] Vadas P, et al. Detection of peanut allergens in breast milk of lactating women. JAMA 2001;285(13):1746-8.

[23] Chirdo FG, et al. Presence of high levels of non-degraded gliadin in breast milk from healthy mothers. Scand J Gastroenterol 1998;33(11):1186-92.

[24] Mosconi E, et al. Breast milk immune complexes are potent inducers of oral tolerance in neonates and prevent asthma development. Mucosal Immunol 2010;3(5):461-74.

[25] Verhasselt V, et al. Breast milk-mediated transfer of an antigen induces tolerance and protection from allergic asthma. Nat Med 2008;14(2): $170-5$.

[26] Holt PG, Batty JE, Turner KJ. Inhibition of specific IgE responses in mice by pre-exposure to inhaled antigen. Immunology 1981;42(3):409-17.

[27] Willoughby JB, Willoughby WF. In vivo responses to inhaled proteins. I. Quantitative analysis of antigen uptake, fate, and immunogenicity in a rabbit model system. J Immunol 1977;119(6):2137-46.

[28] Braley JF, et al. Absorption of inhaled antigen into the circulation of isolated lungs from normal and immunized rabbits. J Clin Invest 1978;61(5):1240-6.

[29] Bensch KG, Dominguez E, Liebow AA. Absorption of intact protein molecules across the pulmonary air-tissue barrier. Science 1967;157 (3793):1204-6.

[30] Casas R, Bjorksten B. Detection of Fel d 1-immunoglobulin G immune complexes in cord blood and sera from allergic and non-allergic mothers. Pediatr Allergy Immunol 2001;12(2):59-64.

[31] Holloway JA, et al. Detection of house-dust-mite allergen in amniotic fluid and umbilical-cord blood. Lancet 2000;356(9245):1900-2.

[32] Macchiaverni P, et al. Mother to child transfer of IgG and IgA antibodies against Dermatophagoides pteronyssinus. Scand J Immunol 2011.

33] Faria AM, Weiner HL. Oral tolerance. Immunol Rev 2005;206:232-59.

[34] Roopenian DC, Akilesh S. FcRn: the neonatal Fc receptor comes of age. Nat Rev Immunol 2007;7(9):715-25.

[35] Brandtzaeg PE. Current understanding of gastrointestinal immunoregulation and its relation to food allergy. Ann N Y Acad Sci 2002;964:13-45.

[36] Menard S, Cerf-Bensussan N, Heyman M. Multiple facets of intestinal permeability and epithelial handling of dietary antigens. Mucosal Immunol 2010;3(3):247-59.

[37] Neville MC, et al. Studies on human lactation. I. Within-feed and betweenbreast variation in selected components of human milk. Am J Clin Nutr 1984;40(3):635-46.

[38] Benn CS, et al. Mammary epithelial paracellular permeability in atopic and non-atopic mothers versus childhood atopy. Pediatr Allergy Immunol 2004;15(2):123-6.

[39] Kim YW, Halsey JF. Metabolism and clearance of antibody-excess immune complexes in lactating mice. J Immunol 1982;129(2):619-22.

[40] Cianga $\mathrm{P}$, et al. Identification and function of neonatal $\mathrm{Fc}$ receptor in mammary gland of lactating mice. Eur J Immunol 1999;29(8):2515-23.

[41] Husby S, et al. Humoral immunity to dietary antigens in healthy adults. Occurrence, isotype and $\mathrm{IgG}$ subclass distribution of sérum antibodies to protein antigens. Int Arch Allergy Appl Immunol 1985;77(4):416-22.

[42] Haddad ZH, et al. Detection and kinetics of antigen-specific IgE and IgG immune complexes in food allergy. Ann Allergy 1983;51(2 Pt 2):255.

[43] Van Niel G, et al. Intestinal epithelial exosomes carry MHC class II/ peptides able to inform the immune system in mice. Gut 2003;52(12): $1690-7$.

[44] Karlsson M, et al. "Tolerosomes" are produced by intestinal epithelial cells. Eur J Immunol 2001;31(10):2892-900.

[45] Admyre C, et al. Exosomes with immune modulatory features are present in human breast milk. J Immunol 2007;179(3):1969-78.

[46] Li MO, Flavell RA. TGF-beta: a master of all T cell trades. Cell 2008;134(3):392-404.

[47] Penttila IA, et al. Transforming growth factor-beta levels in maternal milk and expression in postnatal rat duodenum and ileum. Pediatr Res 1998;44(4):524-31.

[48] Penttila IA, et al. Maternal milk regulation of cell infiltration and interleukin 18 in the intestine of suckling rat pups. Gut 2003;52(11):1579-86.

[49] Penttila I. Effects of transforming growth factor-beta and formula feeding on systemic immune responses to dietary beta-lactoglobulin in allergyprone rats. Pediatr Res 2006;59(5):650-5.
[50] Oddy WH, Rosales F. A systematic review of the importance of milk TGFbeta on immunological outcomes in the infant and young child. Pediatr Allergy Immunol 2010;21(1 Pt 1):47-59.

[51] Prescott SL, et al. Supplementation with Lactobacillus rhamnosus or Bifidobacterium lactis probiotics in pregnancy increases cord blood interferon-gamma and breast milk transforming growth factorbeta and immunoglobin A detection. Clin Exp Allergy 2008;38(10): 1606-14.

[52] Bottcher MF, et al. Low breast milk TGF-beta2 is induced by Lactobacillus reuteri supplementation and associates with reduced risk of sensitization during infancy. Pediatr Allergy Immunol 2008;19(6):497-504.

[53] Garofalo R. Cytokines in human milk. J Pediatr 2010;156(2 Suppl.): S36-40.

[54] Mosconi E, et al. Breast milk immune complexes are potent inducers of oral tolerance in neonates and prevent asthma development. Mucosal Immunol 2010.

[55] Caulfield MJ, Shaffer D. Immunoregulation by antigen/antibody complexes. I. Specific immunosuppression induced in vivo with immune complexes formed in antibody excess. J Immunol 1987;138(11):3680-3.

[56] Machiels JJ, et al. Allergic bronchial asthma due to Dermatophagoides pteronyssinus hypersensitivity can be efficiently treated by inoculation of allergen-antibody complexes. J Clin Invest 1990;85(4):1024-35.

[57] Nimmerjahn F, Ravetch JV. Fcgamma receptors as regulators of immune responses. Nat Rev Immunol 2008;8(1):34-47.

[58] Korotkova M, et al. The ratio of $n-6$ to $n-3$ fatty acids in maternal diet influences the induction of neonatal immunological tolerance to ovalbumin. Clin Exp Immunol 2004;137(2):237-44.

[59] Schack L, et al. Considerable variation in the concentration of osteopontin in human milk, bovine milk, and infant formulas. J Dairy Sci 2009;92(11) 5378-85.

[60] Cantor H, Shinohara ML. Regulation of T-helper-cell lineage development by osteopontin: the inside story. Nat Rev Immunol 2009;9(2): $137-41$.

[61] Strober W. Vitamin A rewrites the ABCs of oral tolerance. Mucosal Immunol 2008;1(2):92-5.

[62] Schams D, Karg H. Hormones in milk. Ann N Y Acad Sci 1986;464: $75-86$.

[63] Cummins AG, Thompson FM. Effect of breast milk and weaning on epithelial growth of the small intestine in humans. Gut 2002;51(5): 748-54.

[64] Dvorak B. Milk epidermal growth factor and gut protection. J Pediatr 2010;156(2 Suppl.):S31-5.

[65] Wen L, et al. Innate immunity and intestinal microbiota in the development of Type 1 diabetes. Nature 2008;455(7216):1109-13

[66] Lonnqvist A, et al. Neonatal exposure to staphylococcal superantigen improves induction of oral tolerance in a mouse model of airway allergy. Eur J Immunol 2009;39(2):447-56.

[67] Bjorksten B. Effects of intestinal microflora and the environment on the development of asthma and allergy. Springer Semin Immunopatho 2004;25(3-4):257-70.

[68] Adlerberth I, Wold AE. Establishment of the gut microbiota in Western infants. Acta Paediatr 2009;98(2):229-38.

[69] Kramer MS. Breastfeeding and allergy: the evidence. Ann Nutr Metab 2011;59(Suppl. 1):20-6.

[70] Greer FR, Sicherer SH, Burks AW. Effects of early nutritional interventions on the development of atopic disease in infants and children: the role of maternal dietary restriction, breastfeeding, timing of introduction of complementary foods, and hydrolyzed formulas. Pediatrics 2008;121(1): 183-91.

[71] Zeiger RS. Food allergen avoidance in the prevention of food allergy in infants and children. Pediatrics 2003;111(6 Pt 3):1662-71.

[72] van Odijk J, et al. Breastfeeding and allergic disease: a multidisciplinary review of the literature (1966-2001) on the mode of early feeding in infancy and its impact on later atopic manifestations. Allergy 2003;58(9):833-43.

[73] Gdalevich M, Mimouni D, Mimouni M. Breast-feeding and the risk of bronchial asthma in childhood: a systematic review with meta-analysis of prospective studies. J Pediatr 2001;139(2):261-6. 
+ Models

REVAL 482 1-7

P. Macchiaverni et al. / Revue française d'allergologie $x x x$ (2012) $x x x-x x x$

7

620

622

623

624

625

626

627

628

629

630

631

632

633

634

635

636

637

638

639

640

641
[74] Gull I, et al. Breastfeeding reduces the risk of asthma during the first 4 years of life. J Allergy Chin Immunol 2004;114(4):755-60.

[75] Scholtens S, et al. Breast feeding, parental allergy and asthma in children followed for 8 years. The PIAMA birth cohort study. Thorax 2009;64(7): 604-9.

[76] Sears MR, et al. Long-term relation between breastfeeding and developmont of atopy and asthma in children and young adults: a longitudinal study. Lancet 2002;360(9337):901-7.

[77] Sicherer SH. The impact of maternal diets during breastfeeding on the prevention of food allergy. Cor Spin Allergy Chin Immunol 2002;2(3): 207-10.

[78] Palmer DJ, Makrides M. Diet of lactating women and allergic reactions in their infants. Cor Open Chin Nutr Metab Care 2006;9(3):284-8.

[79] Lack G. The concept of oral tolerance induction to foods. Nestle Nutr Workshop Ser Pediatr Program 2007;59:63-8 [discussion 68-72].

[80] Prescott SL, et al. The importance of early complementary feeding in the development of oral tolerance: concerns and controversies. Pediatr Allergy Immunol 2008;19(5):375-80.

[81] Kramer MS, Kakuma R. Maternal dietary antigen avoidance during pregnancy or lactation, or both, for preventing or treating topic disease in the child. Cochrane Database Syst Rev 2006;3:CD000133.
[82] Du Toil G, et al. Early consumption of peanuts in infancy is associated with a low prevalence of peanut allergy. J Allergy Chin Immunol 2008;122(5):984-91.

[83] Lack G. Epidemiologic risks for food allergy. J Allergy Chin Immunol 2008;121(6):1331-6.

[84] Komatsu T, et al. Effects of early antigen exposure through lactation on later specific antibody responses in mice. J Immunol 1988;141(9):2895-906.

[85] Telemo E, et al. Maternal dietary antigens and the immune response in the offspring of the guinea-pig. Immunology 1987;62(1):35-8.

[86] Auerbach R, Clark S. Immunological tolerance: transmission from mother to offspring. Science 1975;189(4205):811-3.

[87] Strobel S, Ferguson A. Immune responses to fed protein antigens in mice. 3. Systemic tolerance or priming is related to age at which antigen is first encountered. Pediatr Res 1984;18(7):588-94.

[88] Lopez-Exposito I, et al. Maternal peanut exposure during pregnancy and lactation reduces peanut allergy risk in offspring. J Allergy Chin Immunol 2009;124(5):1039-46.

[89] Yamamoto T, et al. Oral tolerance induced by transfer of food antigens via breast milk of allergic mothers prevents offspring from developing allergic symptoms in a mouse food allergy model. Chin Lev Immunol 2012;2012: 721085.
641

642

643

644

645

646

647

648

649

650

651

652

653

654

655

656

657

658

659

660

661

662

Pour cites et article : Macchiaverni P, et al. L'allaitement maternel peut-il prévenir les maladies allergiques par l'induction de tolerance orle ?.

Rev Fr Allergol (2012), http://dx.doi.org/10.1016/j.reval.2012.08.002 


\section{APÊNCIDE C}

Questionário e termo de consentimento aplicado 


\title{
QUESTIONARIO E TERMO DE CONSENTIMENTO APLICADO
}

\author{
TERMO DE CONSENTIMENTO LIVRE E ESCLARECIDO
}

Você está sendo convidado(a) a participar do projeto de pesquisa acima citado. O documento abaixo contém todas as informações necessárias sobre a pesquisa que estamos fazendo. Sua colaboração neste estudo será de muita importância para nós, mas se desistir a qualquer momento, isso não causará nenhum prejuízo a você.

$E$ E, ,profissão.

$R G$. CPF. nascido(a) em / /_ concordo de livre espontânea vontade em participar como voluntário(a) do estudo "Estudo da resposta anticórpica materna aos alérgenos D. pteronyssunus $e$ B. tropicalis e sua transferência passiva ao bebê via placenta e aleitamento materno". Declaro que obtive todas as informações necessárias, bem como todos os eventuais esclarecimentos quanto às dúvidas por mim apresentadas.

Estou ciente que:

1) $\quad 0$ estudo se faz necessário para que se possam descobrir as possíveis causas da alergia desencadeadas por ácaros presentes na poeira.

II) Será feita uma coleta de $50 \mathrm{ml}$ de sangue de cordão umbilical logo após o parto e, após 2 dias, uma coleta de $30 \mathrm{ml}$ de sangue materno e outra de $5 \mathrm{ml}$ de colostro. Essas coletas serão feitas apenas para este estudo e em nada influenciarão o meu tratamento; não vão me curar; não vão me causar nenhum problema, exceto o pequeno incômodo de dor no momento da coleta (introdução da agulha para retirada do sangue).

III) A participação neste projeto não tem objetivo de me submeter a um tratamento, bem como não me acarretará qualquer despesa pecuniário com relação aos procedimentos médico-clínicoterapêuticos efetuados com o estudo;

IV) Tenho a liberdade de desistir ou de interromper a colaboração neste estudo no momento em que desejar, sem necessidade de qualquer explicação;

V) A desistência não causará nenhum prejuízo à minha saúde ou bem estar físico. Não virá interferir no atendimento ou no tratamento médico;

VI) Os resultados obtidos durante este ensaio serão mantidos em sigilo, mas concordo que sejam divulgados em publicações científicas, desde que meus dados pessoais não sejam mencionados;

VII) Caso eu desejar, poderei pessoalmente tomar conhecimento dos resultados, ao final desta pesquisa

Desejo conhecer os resultados desta pesquisa. ( ) Sim ou ( ) Não

VIII) Concordo que o material poderá ser utilizado em outros projetos desde que autorizado pela Comissão de Ética deste Instituto e pelo responsável por esta pesquisa. ( ) Sim ou ( ) Não

São Paulo, de de 200

( ) Paciente / ( ) Responsável

Testemunha 1: Nome / RG / Telefone

Testemunha 2: Nome / RG / Telefone

Responsável pelo Projeto: Dr. Antônio Condino Neto; Pediatra; CRM 51.204

Telefone para contato: (11) 30917387 
Questionário aplicado

I- Identificação da mãe
Leito __ identificação
Nome:-

Data de nascimento:

Idade: anos

Telefone: ( )

II- Gestações anteriores:

Número de gestações:

Número de ordem da criança:

III- Quadro alérgico da mãe:

Já fez diagnóstico médico ou apresentou algum tipo de alergia?

$\square \operatorname{Sim} \square$ não

$\underline{Q u a l ?}$

$\square$ Respiratória $\square$ Alimentar $\square$ Ocular

$\square$ Dermatite atópica $\square$ Medicamentosa;

$\square$ outros

Se for respiratória, especificar:

$\square$ Asma

- Tosse principalmente na metade da noite e de manhã?

- Sente aperto no peito ("peito preso")?

- Tem falta de ar (respiração incompleta)?

- Apresenta chiado no peito?

$\square$ Rinite alérgica

- Tem vários espirros em sucessão, especialmente pela manhã?

- Seu nariz escorre e fica obstruído?

- Ocorrem irritação e coceira no nariz, nos olhos e no céu da boca?

- Seu olfato fica prejudicado?

-Tem dores de cabeça juntamente com outros

sintomas destes já mencionados?

Houve ocorrência de processo alérgico durante a gestação?

$\square \operatorname{Sim} \square$ Não

Qual trimestre?

$\square 1^{\circ} \square 2^{\circ} \square 3^{\circ}$

Se a resposta for positiva, identificar:

$\square$ Respiratória $\square$ Alimentar $\square$ Ocular

$\square$ Dermatite atópica $\square$ Medicamentosa;

$\square$ Outros

Se for respiratória, especificar: $\square$ Asma $\square$ Rinite alérgica

IV: Dados do recém nascido

Parto: $\square$ cesárea $\square$ normal $\square$ fórceps

Tempo gest.: $\square$ termo $\square$ pré-termo $\square$ pós-termo

Peso: ___ Comprimento Apgar 1-5

Ficou na UTI? $\square$ Sim $\square$ Não

Sexo: $\square$ Feminino $\square$ Masculino

V- Quadro alérgico da família:

O pai da criança Já fez diagnóstico médico ou apresentou algum tipo de alergia?

$\square \operatorname{Sim} \square$ Não $\square$ Não sabe

Se a resposta for positiva, identificar:

$\square$ Respiratória $\square$ Alimentar $\square$ Ocular

$\square$ Dermatite atópica $\square$ Medicamentosa;

$\square$ Outros

Se for respiratória, especificar:

$\square$ Asma $\square$ Rinite alérgica

Algum irmão da criança Já fez diagnóstico médico ou apresentou algum tipo de alergia?

$\square$ sim $\square$ não $\square$ não sabe

Qual gestação e sexo?

$\square \square$ 1 a gestação $\square \square 2^{\text {a }}$ gestação $\square \square$ 3모 gestação

$\square \square$ 4a gestação

Se a resposta for positiva, identificar:

$\square$ Respiratória $\square$ Alimentar $\square$ Ocular

$\square$ Dermatite atópica $\square$ Medicamentosa;

$\square$ outros

Se for respiratória, especificar:

$\square$ Asma $\square$ Rinite alérgica

VI- Características do quarto:

Tipo de piso

$\square$ Carpete $\square$ Piso frio $\square$ Tapetes

Cortinas

$\square$ não tem $\square$ lava uma vez a cada 2 meses

$\square$ demora mais de 2 meses para lavar

Tipo de travesseiro

$\square$ espuma $\square$ com capa adequada $\square$ não sabe

Tipo de colchão:

$\square$ Espuma ou mola $\square$ Com capa adequada

Idade do Colchão:

$\square$ menos de 1 ano $\square 1$ a 4 anos $\square$ mais de 5 anos Ambiente

$\square$ arejado com sol $\square$ arejado sem sol $\square$ úmido

$\underline{\text { Região em que mora }} \square$ área rural $\square$ área urbana 


\section{VII- Condição Sócio Econômica}

Grau de instrução:

$\square$ ignorada $\square$ analfabeta
$\square$ ensino fundamental:
$\square$ ensino médio : $\_$ano
$\square$ ensino superior: $\square$ incompleto $\square$ completo

Curso

Convênio médico: $\square \operatorname{sim} \square$ não $\square$ particular

Meio de transporte:

$\square$ ônibus $\square$ carro próprio $\square$ outro

Rendimento familiar:

Renda mensal reais

№ moradores Menores 12 anos:

VIII- Classificação por bens:

\begin{tabular}{|c|c|c|c|c|c|}
\hline Posse de bens & 0 & 1 & 2 & 3 & 4 ou mais \\
\hline \multicolumn{6}{|l|}{ TV a cores } \\
\hline \multicolumn{6}{|l|}{ Rádio } \\
\hline \multicolumn{6}{|l|}{ Banheiro } \\
\hline \multicolumn{6}{|l|}{ Automóvel } \\
\hline \multicolumn{6}{|l|}{ Empregada } \\
\hline \multicolumn{6}{|l|}{ Aspirador } \\
\hline \multicolumn{6}{|l|}{ Máquina de lavar } \\
\hline \multicolumn{6}{|l|}{ Videocassete } \\
\hline \multicolumn{6}{|l|}{ Geladeira } \\
\hline Freezer & & & & & \\
\hline
\end{tabular}

Moradia:

$\square$ própria

$\square$ alugada

$\square$ financiada reais

$\square$ agregada

$\square$ cedida

Tipo de casa:

$\square$ alvenaria $\square$ madeira $\square$ barraco (papelão,tábua...) $\square$ outros

Número de cômodos:

$\square$ total

$\square$ quarto $\square$ sala $\square$ cozinha $\square$ sanitário

Infra-estrutura básica:

$\square$ Esgoto $\square$ água encanada $\square$ energia elétrica $\square$ coleta de lixo $\square$ asfalto 
Anexo A

Níveis de anticorpos lgE totais e específicos e dados da mãe e do recém-nascido. 
Anexo A - Níveis de anticorpos IgE totais e específicos e dados da mãe e do recém-nascido.

(continua)

\begin{tabular}{|c|c|c|c|c|c|c|c|c|c|c|c|c|c|}
\hline \multirow[b]{2}{*}{ Id entific ação da mãe } & \multicolumn{4}{|c|}{$\begin{array}{l}\text { IgE específica - soro materno } \\
\text { (CapSystem Pharmacia) }\end{array}$} & \multirow{2}{*}{$\begin{array}{c}\begin{array}{c}\text { IgE total } \\
\text { Soro } \\
\text { materno }\end{array} \\
(\mathrm{U} / \mathrm{mL})\end{array}$} & \multicolumn{5}{|c|}{ Dados da mãe } & \multicolumn{3}{|c|}{ Dados do recém-nascido } \\
\hline & $\begin{array}{l}\text { IgE anti- } \\
\text { Derp } \\
\text { (classe) }\end{array}$ & $\begin{array}{c}\text { IgE anti- } \\
\text { Derp } \\
\text { (KU/L) }\end{array}$ & $\begin{array}{l}\text { IgE anti-Blot } \\
\text { (classe) }\end{array}$ & $\begin{array}{l}\text { IgE anti-Blot } \\
(\mathrm{KU} / \mathrm{L})\end{array}$ & & Alergia & $\begin{array}{l}\text { Idade } \\
\text { (anos) }\end{array}$ & G.P.A & $\begin{array}{l}\text { tipo de } \\
\text { parto }\end{array}$ & $\begin{array}{c}\text { Tipo de } \\
\text { internação }\end{array}$ & $\begin{array}{l}\text { Peso } \\
\text { (g) }\end{array}$ & $\begin{array}{l}\text { Comprimento } \\
(\mathrm{cm})\end{array}$ & sexo \\
\hline 16 & 3 & 6,16 & 3 & 13,6 & 263,2 & Rinite & 37 & 2.2 .0 & cesária & convênio & 4060 & 51 & M \\
\hline 17 & 6 & 100 & 3 & 6,98 & 565,5 & Rinite & 21 & 1.1 .0 & normal & SUS & 3000 & 49 & M \\
\hline 19 & 3 & 3,46 & 2 & 1,98 & 28,9 & Rinite & 32 & 1.0 .0 & cesária & convênio & 4075 & 53 & M \\
\hline 24 & 4 & 34,5 & 3 & 4,31 & 317,9 & Rinite & 17 & 1.0 .0 & cesária & convênio & 3220 & 49 & $\mathbf{F}$ \\
\hline 38 & 3 & 3,9 & 3 & 4,85 & 39,7 & Rinite & 21 & 1.1 .0 & cesária & convênio & 2790 & 47,5 & M \\
\hline 47 & 4 & 40,7 & 3 & 5,73 & 730,1 & Asma & 20 & 1.1 .0 & normal & SUS & 2930 & 46,7 & M \\
\hline 70 & 4 & 49,6 & 4 & 34,3 & 424,8 & Rinite & 28 & 2.2 .0 & cesária & convênio & 3515 & 49 & $M$ \\
\hline 74 & 4 & 21,6 & 2 & 1,73 & 223,9 & Rinite & 30 & 2.2 .0 & cesária & particular & 3590 & 49 & $\mathbf{F}$ \\
\hline 78 & 4 & 42,9 & 3 & 5,84 & 214,6 & Rinite e asma & 18 & 2.2 .0 & cesária & convênio & 3550 & 50 & $M$ \\
\hline 80 & 4 & 31,7 & 3 & 7,33 & 17,3 & Rinite & 32 & 1.1 .0 & cesária & convênio & 2800 & 46,2 & $\mathbf{F}$ \\
\hline 94 & 3 & 9,01 & 3 & 3,78 & 343,7 & Rinite & 19 & 3.1 .2 & normal & convênio & 3965 & 51 & $\mathbf{F}$ \\
\hline 116 & 3 & 10,2 & 2 & 1,27 & 283,9 & Rinite & 30 & 3.3.0 & cesária & convênio & 3070 & 47,5 & M \\
\hline 122 & 3 & 5,86 & 2 & 0,71 & 179,6 & Rinite & 35 & 2.2 .0 & cesária & convênio & 2755 & 46 & $\mathbf{F}$ \\
\hline 126 & 3 & 3,51 & - & 0 & 27,7 & Rinite & 21 & 1.1 .0 & normal & convênio & 2995 & 49 & $\mathbf{F}$ \\
\hline 4 & 4 & 26,9 & 2 & 3,23 & 569 & Rinite & 26 & 2.2 .0 & cesária & SUS & 3215 & 47,5 & $\mathbf{F}$ \\
\hline 13 & 3 & 8,7 & - & 0 & 88 & Rinite & 25 & 1.1 .0 & cesária & convênio & 3250 & 47 & $M$ \\
\hline 7 & 5 & 52,4 & - & - & 804,4 & Rinite & 28 & 2.2 .0 & normal & convênio & 3080 & 48 & $\mathbf{F}$ \\
\hline 17 & 5 & 92,4 & - & - & 3910 & Rinite & 23 & 1.1 .0 & cesária & convênio & 3665 & 51 & M \\
\hline 23 & 4 & 25 & - & - & 237,7 & Rinite & 40 & 2.2 .0 & cesária & particular & 3240 & 47,3 & $F$ \\
\hline 34 & 3 & 11,5 & 1 & 0,39 & 51,4 & $\begin{array}{l}\text { Rinite e } \\
\text { dermatite }\end{array}$ & 30 & 1.1 .0 & cesária & convênio & 3760 & 50,5 & $\mathbf{F}$ \\
\hline 38 & 4 & 20,7 & 3 & 4 & 1487,3 & Rinite & 16 & 1.1 .0 & normal & SUS & 3000 & 47,8 & $\mathbf{F}$ \\
\hline 94 & 5 & 99,5 & 2 & 2,24 & 422,9 & Rinite & 26 & 3.3.0 & cesária & convênio & 3150 & 47,7 & $M$ \\
\hline 97 & 3 & 12,2 & 1 & 0,58 & 296,1 & Rinite & 24 & 1.1 .0 & cesária & SUS & 2325 & 45 & $M$ \\
\hline 104 & 4 & 46,3 & 3 & 5,79 & 264 & Rinite & 32 & 1.1 .0 & cesária & convênio & 3510 & 50 & $\mathbf{F}$ \\
\hline 109 & 3 & 3,64 & 3 & 6,56 & 78,8 & Rinite & 29 & 2.2 .0 & cesária & convênio & 3240 & 49 & $M$ \\
\hline 115 & 3 & 3,78 & 2 & 0,88 & 243,7 & Rinite & 20 & 1.1 .0 & cesária & convênio & 3580 & 50,5 & $M$ \\
\hline 134 & 5 & 71,2 & - & - & 998,8 & Rinite & 30 & $3,3,0$ & cesária & convênio & 2750 & 47 & $\mathbf{F}$ \\
\hline 145 & 3 & 16,2 & 3 & 5,05 & 194,5 & Rinite & 22 & $1,1,0$ & normal & convênio & 2935 & 47,5 & $\mathbf{F}$ \\
\hline 148 & 3 & 9,4 & 1 & 0,45 & 25,1 & Rinite & 39 & $1,1,0$ & cesária & particular & 4220 & 51,5 & $M$ \\
\hline
\end{tabular}


(continuação)

\begin{tabular}{|c|c|c|c|c|c|c|c|c|c|c|c|c|c|}
\hline \multirow[b]{2}{*}{ Identific ação da mãe } & \multicolumn{4}{|c|}{$\begin{array}{l}\text { IgE específica - so ro materno } \\
\text { (CapSystem Pharmacia) }\end{array}$} & \multirow{2}{*}{$\begin{array}{c}\begin{array}{c}\text { IgE total } \\
\text { Soro } \\
\text { materno }\end{array} \\
\text { (UI/mL) }\end{array}$} & \multicolumn{5}{|c|}{ Dados da mãe } & \multicolumn{3}{|c|}{ Dados do recém-nascido } \\
\hline & $\begin{array}{c}\text { IgE anti- } \\
\text { Derp } \\
\text { (classe) }\end{array}$ & $\begin{array}{c}\text { IgE anti- } \\
\text { Derp } \\
\text { (KU/L) } \\
\end{array}$ & $\begin{array}{l}\text { IgE anti-Blot } \\
\text { (classe) }\end{array}$ & $\begin{array}{l}\text { IgE anti-Blot } \\
\text { (KU/L) }\end{array}$ & & Alergia & $\begin{array}{l}\text { Idade } \\
\text { (anos) }\end{array}$ & G.P.A & $\begin{array}{l}\text { tipo de } \\
\text { parto }\end{array}$ & $\begin{array}{l}\text { Tipo de } \\
\text { internação }\end{array}$ & $\begin{array}{l}\text { Peso } \\
\text { (g) }\end{array}$ & $\begin{array}{l}\text { Comprimento } \\
(\mathrm{cm})\end{array}$ & sexo \\
\hline 3 & 0 & $<0,35$ & 0 & $<0,35$ & 207,3 & Não & 33 & 3.3.0 & normal & SUS & 3590 & 51 & $\mathbf{F}$ \\
\hline 9 & 0 & $<0,35$ & 0 & $<0,35$ & 37,3 & Não & 26 & 2.1 .0 & cesária & convênio & 3430 & 48,5 & M \\
\hline 14 & 0 & $<0,35$ & 0 & $<0,35$ & 18,2 & Não & 25 & 2.2 .0 & cesária & convênio & 3360 & 50 & M \\
\hline 21 & 0 & $<0,35$ & 0 & $<0,35$ & 20,4 & Não & 34 & 2.2.0 & cesária & convênio & 3800 & 51 & $\mathbf{F}$ \\
\hline 22 & 0 & $<0,35$ & 0 & $<0,35$ & 71,3 & Não & 20 & 1.1 .0 & normal & SUS & 3150 & 47,5 & $\mathbf{F}$ \\
\hline 23 & 0 & $<0,35$ & 0 & $<0,35$ & 30,5 & Não & 32 & 2.2 .0 & cesária & convênio & 3380 & 48,5 & $\mathbf{F}$ \\
\hline 27 & 0 & $<0,35$ & 0 & $<0,35$ & 330,9 & Não & 23 & 3.3.0 & normal & SUS & 2945 & 49,5 & $M$ \\
\hline 29 & 0 & $<0,35$ & 0 & $<0,35$ & 16,2 & Não & 28 & 2.2.0 & cesária & SUS & 4075 & 51 & $M$ \\
\hline 30 & 0 & $<0,35$ & 0 & $<0,35$ & 2,4 & Não & 27 & 2.2.0 & cesária & convênio & 3255 & 48,5 & $\mathbf{F}$ \\
\hline 32 & 0 & $<0,35$ & 0 & $<0,35$ & 11,6 & Não & 31 & 2.2 .0 & cesária & convênio & 3780 & 48,5 & $M$ \\
\hline 46 & 0 & $<0,35$ & 0 & $<0,35$ & 4,6 & Não & 25 & 1.1 .0 & normal & convênio & 2730 & 45,5 & $\mathbf{F}$ \\
\hline 51 & 0 & $<0,35$ & 0 & $<0,35$ & 40,3 & Não & 29 & 2.2 .0 & cesária & convênio & 3410 & 49 & $\mathbf{F}$ \\
\hline 64 & 0 & $<0,35$ & 0 & $<0,35$ & 24,7 & Não & 28 & 2.1 .0 & cesária & convênio & 3260 & 49 & $\mathbf{F}$ \\
\hline 68 & 0 & $<0,35$ & 0 & $<0,35$ & 7,7 & Não & 22 & 2.2.0 & cesária & convênio & 3180 & 47 & $\mathbf{F}$ \\
\hline 103 & 0 & $<0,35$ & & $<0,35$ & 10,4 & Não & 20 & 1.1 .0 & cesária & convênio & 3950 & 52 & $M$ \\
\hline 105 & 0 & $<0,35$ & 0 & $<0,35$ & 14 & Não & 37 & 1.1 .0 & cesária & convênio & 3410 & 50 & $\mathbf{F}$ \\
\hline 111 & 0 & $<0,35$ & 0 & $<0,35$ & 63,2 & Não & 25 & 3.3.0 & normal & SUS & 2400 & 46 & $\mathbf{F}$ \\
\hline 112 & 0 & $<0,35$ & 0 & $<0,35$ & 104,3 & Não & 34 & 4.4 .0 & normal & SUS & 3880 & 48 & $\mathbf{F}$ \\
\hline 117 & 0 & $<0,35$ & 0 & $<0,35$ & 14,6 & Não & 36 & 2.2 .0 & cesária & convênio & 3560 & 49,5 & $\mathbf{F}$ \\
\hline 120 & 0 & $<0,35$ & 0 & $<0,35$ & 5 & Não & 31 & 3.2.1 & cesária & convênio & 3215 & 50 & $M$ \\
\hline 124 & 0 & $<0,35$ & 0 & $<0,35$ & 15,8 & Não & 30 & 2.2 .0 & fórceps & convênio & ni & ni & $\mathbf{F}$ \\
\hline 9 & 0 & $<0,35$ & & & 80,7 & Não & 29 & 1.1 .0 & normal & convênio & 2900 & 49,5 & $\mathbf{F}$ \\
\hline 21 & 0 & $<0,35$ & 0 & $<0,35$ & 74,6 & Não & 34 & 3.3.0 & cesária & convênio & 3480 & 50,5 & $M$ \\
\hline 24 & 0 & $<0,35$ & 0 & $<0,35$ & 16,7 & Não & 18 & 1.1 .0 & cesária & convênio & 3880 & 50,5 & $M$ \\
\hline 32 & 0 & $<0,35$ & 0 & $<0,35$ & 63,1 & Não & 19 & 2.2 .0 & cesária & convênio & 2600 & 46 & $\mathbf{F}$ \\
\hline 44 & 0 & $<0,35$ & & & 13 & Não & 34 & 6.3.3 & cesária & convênio & 4320 & 52,5 & $\mathbf{F}$ \\
\hline 47 & 0 & $<0,35$ & & & 41,5 & Não & 21 & 1.1 .0 & cesária & convênio & 3560 & 51 & $M$ \\
\hline 49 & 0 & $<0,35$ & 0 & $<0,35$ & 12,2 & Não & 17 & 1.1 .0 & cesária & sus & 3425 & 52,8 & $M$ \\
\hline 54 & 0 & $<0,35$ & 0 & $<0,35$ & 9,8 & Não & 29 & 1.1 .0 & cesária & convênio & 4170 & 51,5 & $\mathbf{F}$ \\
\hline
\end{tabular}


(continuação)

\begin{tabular}{|c|c|c|c|c|c|c|c|c|c|c|c|c|c|}
\hline \multirow[b]{2}{*}{ Id entific ação da mãe } & \multicolumn{4}{|c|}{$\begin{array}{l}\text { IgE específica - soro materno } \\
\text { (CapSystem Pharmacia) }\end{array}$} & \multirow{2}{*}{$\begin{array}{c}\begin{array}{c}\text { IgE total } \\
\text { So ro } \\
\text { materno }\end{array} \\
\text { (UI/mL) }\end{array}$} & \multicolumn{5}{|c|}{ Dados da mãe } & \multicolumn{3}{|c|}{ Dados do recém-nascido } \\
\hline & $\begin{array}{c}\text { IgE anti- } \\
\text { Derp } \\
\text { (classe) }\end{array}$ & $\begin{array}{c}\text { IgE anti- } \\
\text { Derp } \\
\text { (KU/L) }\end{array}$ & $\begin{array}{l}\text { IgE anti-Blot } \\
\text { (classe) }\end{array}$ & $\begin{array}{l}\text { IgE anti-Blot } \\
(\mathrm{KU} / \mathrm{L})\end{array}$ & & Alergia & $\begin{array}{l}\text { Idade } \\
\text { (anos) }\end{array}$ & G.P.A & $\begin{array}{l}\text { tipo de } \\
\text { parto }\end{array}$ & $\begin{array}{l}\text { Tipo de } \\
\text { internação }\end{array}$ & $\begin{array}{l}\text { Peso } \\
\text { (g) }\end{array}$ & $\begin{array}{l}\text { Comprimento } \\
(\mathrm{cm})\end{array}$ & sexo \\
\hline 55 & 0 & $<0,35$ & 0 & $<0,35$ & 1,5 & Não & 30 & 1.1 .0 & cesária & convênio & 3475 & 50,5 & $\mathbf{F}$ \\
\hline 58 & 0 & $<0,35$ & & & 7,8 & Não & 17 & 2.1 .1 & cesária & SUS & 3560 & 50,5 & $\mathbf{F}$ \\
\hline 60 & 0 & $<0,35$ & 0 & $<0,35$ & 11,4 & Não & 23 & 4.4.0 & cesária & particular & 3900 & 50,5 & M \\
\hline 63 & 0 & $<0,35$ & 0 & $<0,35$ & 36,6 & Não & 28 & 1.1.0 & cesária & convênio & 4560 & 51 & $\mathbf{F}$ \\
\hline 84 & 0 & $<0,35$ & 0 & $<0,35$ & 46,4 & Não & 20 & 1.1.1 & normal & sus & 2770 & 46,5 & $\mathbf{F}$ \\
\hline 90 & 0 & $<0,35$ & 0 & $<0,35$ & 24 & Não & 31 & 3.3.0 & cesária & convênio & 3700 & 50,3 & $\mathbf{F}$ \\
\hline 91 & 0 & $<0,35$ & 0 & $<0,35$ & 85,1 & Não & 17 & 2.2.0 & normal & convênio & 3485 & 49 & $\mathbf{F}$ \\
\hline 103 & 0 & $<0,35$ & 0 & $<0,35$ & 5 & Não & 21 & 1.1 .0 & cesária & Convênio & ni & ni & $M$ \\
\hline 116 & 0 & $<0,35$ & 0 & $<0,35$ & 1,5 & Não & 23 & 1.1 .0 & cesária & SUS & 3380 & 48,5 & $\mathbf{F}$ \\
\hline 124 & 0 & $<0,35$ & 0 & $<0,35$ & 129,5 & Não & 15 & 1.1 .0 & normal & sus & 2620 & 44,5 & $\mathbf{F}$ \\
\hline 125 & 0 & $<0,35$ & 0 & $<0,35$ & 27,8 & Não & 33 & 4.4 .0 & cesária & convênio & 3490 & 47 & M \\
\hline 132 & 0 & $<0,35$ & 0 & $<0,35$ & 4,8 & Não & 28 & 1.1 .0 & cesária & convênio & 2890 & 47 & $M$ \\
\hline 133 & 0 & $<0,35$ & 0 & $<0,35$ & 5 & Não & 29 & 1.1 .0 & cesária & SUS & 3250 & 49 & $\mathbf{F}$ \\
\hline 138 & 0 & $<0,35$ & 0 & $<0,35$ & 12,4 & Não & 23 & 3.3.0 & normal & convênio & 3700 & 51,5 & $M$ \\
\hline 139 & 0 & $<0,35$ & 0 & $<0,35$ & 1,5 & Não & 23 & 2.2.0 & cesária & particular & 3370 & 49 & M \\
\hline 142 & 0 & $<0,35$ & 0 & $<0,35$ & 8 & Não & 37 & 3.3.0 & cesária & suS & 2510 & 46 & $\mathbf{F}$ \\
\hline 144 & 0 & $<0,35$ & 0 & $<0,35$ & 13,8 & Não & 20 & 2.2.0 & normal & convênio & 3400 & $n i$ & M \\
\hline 146 & 0 & $<0,35$ & - & - & 48,5 & Não & 37 & 6.6 .0 & normal & SUS & 3190 & 47,5 & $M$ \\
\hline 5 & 1 & 0,04 & 0 & $<0,35$ & 223,1 & rinite & 19 & 2.2.0 & cesária & sus & 4140 & 50,5 & $\mathbf{F}$ \\
\hline 36 & 2 & 1,17 & 0 & $<0,35$ & 176,2 & rinite & 22 & 2.2.0 & cesária & sus & 3155 & 47,5 & $\mathbf{F}$ \\
\hline 54 & 1 & 0,64 & 2 & 0,73 & 86,9 & rinite & 26 & 3.2.1 & normal & convênio & 2620 & 47 & $M$ \\
\hline 56 & 1 & 0,43 & 0 & $<0,35$ & 1710,7 & asma & 26 & 3.1 .0 & fórceps & SUS & 2620 & 45,5 & M \\
\hline 90 & 2 & 1,25 & 0 & $<0,35$ & 187,8 & rinite & 28 & 1.1 .0 & cesária & convênio & 3670 & 49 & $M$ \\
\hline 101 & 2 & 0,71 & 2 & 0,85 & 141,7 & rinite & 23 & 1.1 .0 & cesária & convênio & 3250 & 47 & $\mathbf{F}$ \\
\hline 109 & 2 & 0,84 & 0 & $<0,35$ & 191,5 & rinite & 39 & 2.2 .0 & cesária & convênio & 3570 & 48 & $M$ \\
\hline 110 & 2 & 0,92 & 0 & $<0,35$ & 106,4 & rinite & 39 & 2.2.0 & cesária & convênio & 3130 & 49,5 & $M$ \\
\hline 118 & 2 & 1,47 & 2 & 1,58 & 155,4 & rinite & 20 & 2.2.0 & normal & SUS & 2975 & 49,5 & $M$ \\
\hline 130 & 1 & 0,56 & 1 & 0,42 & 69,1 & rinite & 17 & 1.1 .0 & cesária & convênio & 3775 & 50 & M \\
\hline 131 & 2 & 1 & 0 & $<0,35$ & 28 & rinite & 30 & 2.2.0 & cesária & convênio & 2700 & 46,5 & $\mathbf{F}$ \\
\hline
\end{tabular}


(conclusão)

\begin{tabular}{|c|c|c|c|c|c|c|c|c|c|c|c|c|c|}
\hline & \multicolumn{4}{|c|}{$\begin{array}{l}\text { IgE específica - soro materno } \\
\quad \text { (CapSystem }{ }^{\circledR} \text { Pharmacia) }\end{array}$} & \multirow{2}{*}{$\begin{array}{c}\begin{array}{c}\text { IgE total } \\
\text { Soro } \\
\text { materno }\end{array} \\
(\mathrm{UI} / \mathrm{mL})\end{array}$} & \multicolumn{5}{|c|}{ Dados da mãe } & \multicolumn{3}{|c|}{ Dados do recém-nascido } \\
\hline Identificação da mãe & $\begin{array}{c}\text { IgE } \\
\text { anti- } \\
\text { Derp } \\
\text { (classe) }\end{array}$ & $\begin{array}{c}\text { IgE } \\
\text { anti- } \\
\text { Derp } \\
\text { (KU/L) }\end{array}$ & $\begin{array}{c}\text { IgE anti- } \\
\text { Blot } \\
\text { (classe) }\end{array}$ & $\begin{array}{c}\text { IgE anti- } \\
\text { Blot } \\
(\text { KU/L) }\end{array}$ & & Alergia & $\begin{array}{l}\text { Idade } \\
\text { (anos) }\end{array}$ & G.P.A & $\begin{array}{l}\text { tipo de } \\
\text { parto }\end{array}$ & $\begin{array}{c}\text { Tipo de } \\
\text { internação }\end{array}$ & $\begin{array}{l}\text { Peso } \\
(\mathrm{g})\end{array}$ & $\begin{array}{l}\text { Comprimento } \\
(\mathrm{cm})\end{array}$ & sexo \\
\hline 41 & 0 & $<0,35$ & 2 & 1,33 & 11,9 & não & 36 & 2.2.0 & cesária & convênio & 3025 & 47,5 & M \\
\hline 107 & 1 & 0,43 & 1 & 0,55 & 66,5 & não & 30 & 3.3.0 & cesária & particular & 3230 & 47,5 & $\mathbf{F}$ \\
\hline 79 & $\mathbf{0}$ & $<0,35$ & 2 & 0,99 & 119,7 & medicamentos & 29 & 2.2.0 & cesária & SUS & 2955 & 47 & $\mathbf{M}$ \\
\hline 91 & 2 & 2,15 & 2 & 3,43 & 802 & insetos & 18 & 2.2 .0 & normal & SUS & 2870 & 47,5 & $\mathbf{M}$ \\
\hline
\end{tabular}


Anexo B

Níveis de $\lg G$ totais e $\lg G$, IgG1, $\lg G 2$, IgG3 e lgG4 específicos em amostras pareadas de soro materno (mãe) e cordão umbilical (RN). 
Anexo B - Níveis de lgG totais e lgG, $\lg G 1$, $\lg G 2$, $\lg G 3$ e $\lg G 4$ específicos em amostras pareadas de soro materno (mãe) e cordão umbilical (RN).

(continua)

\begin{tabular}{|c|c|c|c|c|c|c|c|c|c|c|c|c|c|c|c|c|c|c|c|c|c|c|}
\hline \multirow{3}{*}{ Identificação da mãe } & \multirow{2}{*}{\multicolumn{2}{|c|}{$\begin{array}{l}\text { IgG sérica total } \\
(\mathrm{mg} / \mathrm{dL})\end{array}$}} & \multicolumn{4}{|c|}{$\begin{array}{l}\text { IgG sérica específica } \\
(U A / \mathrm{mL})\end{array}$} & \multicolumn{4}{|c|}{$\begin{array}{l}\text { IgG1 específica } \\
\text { (UA/mL) }\end{array}$} & \multicolumn{4}{|c|}{$\begin{array}{l}\text { IgG2 específica } \\
\text { (UA/mL) }\end{array}$} & \multicolumn{4}{|c|}{$\begin{array}{l}\text { IgG3 específica } \\
\text { (UA/mL) }\end{array}$} & \multicolumn{4}{|c|}{$\begin{array}{l}\text { IgG4 específica } \\
\text { (UA/mL) }\end{array}$} \\
\hline & & & \multicolumn{2}{|c|}{ Anti-Der $p$} & \multicolumn{2}{|c|}{ Anti- Blot $t$} & \multicolumn{2}{|c|}{ Anti-Der $p$} & \multicolumn{2}{|c|}{ Anti- Blo $t$} & \multicolumn{2}{|c|}{ Anti-Der $p$} & \multicolumn{2}{|c|}{ Anti- Blo $t$} & \multicolumn{2}{|c|}{ Anti-Der $p$} & \multicolumn{2}{|c|}{ Anti-Blot } & \multicolumn{2}{|c|}{ Anti-Der $p$} & \multicolumn{2}{|c|}{ Anti- Blo $t$} \\
\hline & MÃE & RN & MÃE & RN & MÃE & RN & MÃE & RN & MÃE & RN & MÃE & RN & MÃE & RN & MÃE & RN & MÃE & RN & MÃE & RN & MÃE & RN \\
\hline 16 & 569 & & 440 & 770 & 4480 & 4400 & 102,4 & 149,2 & 28,8 & 94,6 & 5,1 & 4,1 & 1403 & 1673 & 83,36 & 94,24 & 31,27 & 24,73 & 4,1 & 3,44 & 36,8 & 48,5 \\
\hline 17 & 1106 & 1398 & 2600 & 2560 & 50234 & 50234 & 463 & 473,1 & 135 & 178 & 1104 & 1162 & 1111 & 764,4 & 1915,2 & 2463,5 & 87,5 & 70,2 & 5357 & 4498 & 37,4 & 36,1 \\
\hline 19 & 624 & 817 & 416 & 490 & & & 136,6 & 334,9 & & & 1007 & 831,6 & & & 287,44 & 238,08 & & & 0,62 & 0,55 & & \\
\hline 24 & 891 & 855 & 1520 & 1470 & 410 & 436 & 435,2 & 452,6 & 54,1 & 116,9 & 29,6 & 28,6 & 61 & 70 & 563,79 & 560,41 & 10,26 & 17,22 & 5173 & 2629 & 10,8 & 6 \\
\hline 38 & 1117 & 745 & 160 & 84 & 2480 & 1640 & 26,82 & 36,22 & 2,2 & 61,1 & 4,8 & 1,5 & 24,2 & 0 & 63,74 & 22,49 & 4,69 & 6,28 & 51 & 26 & 56,7 & 62,3 \\
\hline 47 & 850 & 953 & 930 & 840 & 23321 & 16577 & 175,9 & 328,3 & 176,2 & 255 & 33,9 & 24,9 & 854 & 865,2 & 759,9 & 392,2 & 27,2 & 15,3 & 571 & 422 & 128 & 141 \\
\hline 70 & 822 & 1015 & 960 & 960 & 3490 & 2789 & 152,4 & 270,9 & 156,4 & 336,4 & 17,4 & 9,9 & 464,7 & 116,8 & 183,44 & 177,01 & 27,38 & 32,3 & 2504 & 1717 & 98,7 & 66,1 \\
\hline 74 & 992 & 873 & 1280 & 1030 & & & 156,5 & 227,4 & & & 96 & 57,4 & & & 624,48 & 493,5 & & & 3073 & 1598 & & \\
\hline 78 & 725 & 1115 & 1726,4 & 2223,6 & 2565 & 3857 & 361,4 & 462,2 & 407 & 1323 & 50,6 & 74 & 82,7 & 112,8 & 521,6 & 492,16 & 14,18 & 15,33 & 943 & 879 & 89,4 & 128 \\
\hline 80 & 838 & 735 & 1520 & 1390 & 6355 & 6708 & 349,2 & 443,9 & 552 & 1152 & 118,3 & 46,3 & 498 & 440,4 & 3133,4 & 2780,2 & 30 & 24,5 & 1440 & 391 & 18,7 & 56,8 \\
\hline 94 & 690 & 919 & 1720 & 1600 & 1110 & 1242 & 155,7 & 414,1 & 142,6 & 118,5 & 81,9 & 45,2 & 236,6 & 297,9 & 310,4 & 346,9 & 633,9 & 861,7 & 1,77 & 3,28 & 7,8 & 9,68 \\
\hline 116 & 978 & 1063 & 2806,4 & 2836,4 & & & 46 & 88,3 & & & 312,7 & 159,9 & & & 344,53 & 467,66 & & & 959 & 805 & & \\
\hline 122 & 921 & 1100 & 2108,8 & 1804 & & & 123,6 & 185,8 & & & 1104 & 993,6 & & & 559,06 & 418,85 & & & 853 & 1126 & & \\
\hline 126 & 797 & 1083 & 1440 & 1760 & & & 126 & 274 & & & 195,6 & 246,4 & & & 227,88 & 246,44 & & & 1525 & 1359 & & \\
\hline 4 & 960 & 1305 & 971,6 & 959,2 & & & 418,3 & 860,3 & & & 12,5 & 18,8 & & & 167,34 & 157,45 & & & 12,0 & 16,8 & & \\
\hline 13 & 752 & 834 & 1033,6 & 847,2 & & & 91,5 & 72,4 & & & 410,5 & 396,1 & & & 129,07 & 91,46 & & & 29,2 & 29,4 & & \\
\hline 7 & 860 & 1050 & 1266 & 989 & & & 13,2 & 48,1 & & & 217 & 193,4 & & & 723,96 & 630,23 & & & 67,4 & 85,8 & & \\
\hline 17 & 1280 & 1730 & 220 & 292 & & & 21,5 & 62,7 & & & 38,1 & 49,3 & & & 132,17 & 74,65 & & & 124 & 142 & & \\
\hline 23 & 725 & 1150 & 3321 & 3704 & & & 14,4 & 52,3 & & & 1344 & 989,2 & & & 282,6 & & & & 8,2 & 18,2 & & \\
\hline 34 & 698 & 1500 & 130 & 220 & & & 237,4 & 185,4 & & & 9,2 & 17,4 & & & & 102,6 & & & 0,5 & 0 & & \\
\hline
\end{tabular}


(continuação)

\begin{tabular}{|c|c|c|c|c|c|c|c|c|c|c|c|c|c|c|c|c|c|c|c|c|c|c|}
\hline \multirow{3}{*}{ Identificação da mãe } & \multirow{2}{*}{\multicolumn{2}{|c|}{$\begin{array}{l}\text { IgG sérica total } \\
(\mathrm{mg} / \mathrm{dL})\end{array}$}} & \multicolumn{4}{|c|}{$\begin{array}{l}\text { IgG sérica específica } \\
(\mathrm{UA} / \mathrm{mL})\end{array}$} & \multicolumn{4}{|c|}{$\begin{array}{l}\text { IgG1 específica } \\
\text { (UA/mL) }\end{array}$} & \multicolumn{4}{|c|}{$\begin{array}{l}\text { IgG2 específica } \\
\text { (UA/mL) }\end{array}$} & \multicolumn{4}{|c|}{$\begin{array}{l}\text { IgG3 específica } \\
\text { (UA/mL) }\end{array}$} & \multicolumn{4}{|c|}{$\begin{array}{l}\text { IgG4 específica } \\
\text { (UA/mL) }\end{array}$} \\
\hline & & & \multicolumn{2}{|c|}{ Anti-Der $p$} & \multicolumn{2}{|c|}{ Anti- Blot } & \multicolumn{2}{|c|}{ Anti-Der $p$} & \multicolumn{2}{|c|}{ Anti- Blo $t$} & \multicolumn{2}{|c|}{ Anti-Der $p$} & \multicolumn{2}{|c|}{ Anti- Blo $t$} & \multicolumn{2}{|c|}{ Anti-Der $p$} & \multicolumn{2}{|c|}{ Anti- Blo $t$} & \multicolumn{2}{|c|}{ Anti-Der $p$} & \multicolumn{2}{|c|}{ Anti- Blot } \\
\hline & MÃE & RN & MÃE & RN & MÃE & RN & MÃE & RN & MÃE & RN & MÃE & RN & MÃE & RN & MÃE & RN & MÃE & RN & MÃE & RN & MÃE & RN \\
\hline 38 & 1050 & 1140 & 247 & 250 & & 2019 & 49,3 & 98,7 & 199,5 & 222 & 9,5 & 9,8 & 95,2 & 43,3 & & & & & 29,7 & 22,1 & 10,0 & 7,5 \\
\hline 94 & 809 & 1390 & 1000 & 1188 & & & 133,5 & 146,4 & & & 205 & 221,5 & & & & 601,32 & & & 44,6 & 41,1 & & \\
\hline 97 & 776 & 1220 & 2620 & 3498 & & & 126,8 & 170,3 & & & 110 & 122,3 & & & & 217,16 & & & 5,4 & 7,3 & & \\
\hline 104 & 887 & 1130 & 1839 & 1686 & & & 235,8 & 1091 & 32,4 & & 764, & 770,2 & 758,7 & 803,3 & & & & & 16,2 & 11,6 & 52,2 & \\
\hline 109 & 1540 & 1540 & 2999 & 2791 & & 7938 & 109,6 & 213,1 & 23,12 & 81,4 & 1019 & 912 & 117,4 & 173,2 & & 540,28 & & 142,4 & 47,2 & 55,5 & 45,9 & 54,9 \\
\hline 115 & 903 & 1170 & 215 & 234 & & & 76,9 & 177,9 & & & 18,3 & 14,4 & & & & & & & 1 & 0,7 & & \\
\hline 134 & 891 & 871 & 368 & 271 & & & 10,9 & 43,9 & & & 64,8 & 65,8 & & & 109,7 & & & & 11,9 & 15,8 & & \\
\hline 145 & 884 & 1300 & 800 & 1457 & & 26,5 & 1204 & 1902 & 111,7 & 121,1 & 10,4 & 11,6 & 184 & 69 & & 450,52 & & 55,88 & 26,5 & 21,7 & 6,72 & 5,79 \\
\hline 148 & 1040 & 983 & 1503 & 1121 & & & 234,4 & 317,3 & & & 835 & 268,6 & & & & 1375,9 & & & 24,8 & 23,1 & & \\
\hline 3 & 862 & 1228 & 1218 & 932 & 60,36 & 8308 & 245,4 & 486,8 & 82,9 & 183,6 & 1219 & 1006 & 262,4 & 180,3 & 534,97 & 589,97 & 37,35 & 38,92 & 0 & 0 & 3,21 & 5,15 \\
\hline 9 & 893 & 744 & 674,4 & 490,6 & 1150 & 800 & 137 & 221 & 131,4 & 167,6 & 16,2 & 7,6 & 491,6 & 254 & 1666,6 & 1188,8 & 20,07 & 31,44 & 0,38 & 0,67 & 31,1 & 13,7 \\
\hline 14 & 635 & 1070 & 683,2 & 1051,2 & 283,8 & 543,8 & 289,5 & 635 & 42 & 214 & 7,6 & 5,7 & 83,4 & 88,5 & 1180,3 & 1643,8 & 29,51 & 24,83 & 1,52 & 1,78 & 7,64 & 12,47 \\
\hline 21 & 542 & 849 & 705,2 & 1318,8 & 305 & 541,5 & 405,2 & 463,91 & 172 & 146 & 7,6 & 10,8 & 0 & 0 & 555,55 & 667,49 & 6,12 & 8,78 & 22,86 & 19,7 & 33,2 & 30,5 \\
\hline 22 & 709 & 973 & 434,8 & 300,4 & 62,4 & 47,4 & 13 & 75,84 & 25,8 & 62,8 & 33 & 14,6 & 239,5 & 401,6 & 93,99 & 62,66 & 15,28 & 27,65 & 2 & 0,48 & 19,44 & 14,52 \\
\hline 23 & 832 & 886 & 846,4 & 820,8 & 650 & 600 & 96,2 & 131,7 & 121 & 116,4 & 134 & 128,5 & 1153 & 968,7 & 308,85 & 192,96 & 4,6 & 4,1 & 20,5 & 15,96 & 23,5 & 12,3 \\
\hline 27 & 908 & 994 & 240 & 180 & 463 & 306 & 16,8 & 20,4 & 93,2 & 132 & 4,2 & 8,9 & 144,5 & 152,8 & 81,2 & 54,96 & 17,43 & 30,44 & 16,48 & 14,68 & 34,4 & 77,1 \\
\hline 29 & 720 & 721 & 667,2 & 586 & 1063,5 & 608,5 & 50,3 & 157,8 & 20,6 & 20,2 & 500 & 313,1 & 606,8 & 672,6 & 295,16 & 327,16 & 4,07 & 3,06 & 6,06 & 3,36 & 9,22 & 7,36 \\
\hline 30 & 773 & 973 & 645,6 & 524,8 & 3974 & 3176 & 17,65 & 57,6 & 19,4 & 59,8 & 18 & 38,8 & 49,3 & 66,5 & 3654,2 & 7058,7 & 7,56 & 11,67 & 0,5 & 0,3 & 13,4 & 6 \\
\hline 32 & 658 & 717 & 866,4 & 960 & 379 & 268,5 & 234,6 & 295,3 & 30,8 & 88,4 & 15,1 & 13,4 & 250 & 410,2 & 239,32 & 226,16 & 3,8 & 5,2 & 12 & 10,54 & 8,04 & 7,05 \\
\hline 46 & 798 & 996 & 2627 & 3071,5 & 15180 & 19712 & 157 & 253,4 & 94 & 144,6 & 395 & 261,8 & 0 & 0 & 3356,7 & 4854,7 & 51,12 & 46,86 & 19,7 & 17,58 & 6,4 & 3,24 \\
\hline
\end{tabular}


(continuação)

\begin{tabular}{|c|c|c|c|c|c|c|c|c|c|c|c|c|c|c|c|c|c|c|c|c|c|c|}
\hline \multirow{3}{*}{ Iden tificação } & \multirow{2}{*}{\multicolumn{2}{|c|}{$\begin{array}{l}\text { IgG sérica total } \\
(\mathrm{mg} / \mathrm{dL})\end{array}$}} & \multicolumn{4}{|c|}{$\begin{array}{l}\text { IgG sérica especifica } \\
\text { (UA/mL) }\end{array}$} & \multicolumn{4}{|c|}{$\begin{array}{l}\text { IgG1 específica } \\
\text { (UA/mL) }\end{array}$} & \multicolumn{4}{|c|}{$\begin{array}{l}\text { IgG2 es pecífica } \\
(\mathrm{UA} / \mathrm{mL})\end{array}$} & \multicolumn{4}{|c|}{$\begin{array}{l}\text { IgG3 e specífica } \\
(U A / \mathrm{mL})\end{array}$} & \multicolumn{4}{|c|}{$\begin{array}{l}\text { IgG4 es pecífica } \\
\text { (UA/mL) }\end{array}$} \\
\hline & & & \multicolumn{2}{|c|}{ Anti-Derp } & \multicolumn{2}{|c|}{ Anti Blot } & \multicolumn{2}{|c|}{ Anti-Der $p$} & \multicolumn{2}{|c|}{ Anti- Blo $t$} & \multicolumn{2}{|c|}{ Anti-Der $p$} & \multicolumn{2}{|c|}{ Anti Blot } & \multicolumn{2}{|c|}{ Anti-Der $p$} & \multicolumn{2}{|c|}{ Anti-Blot } & \multicolumn{2}{|c|}{ Anti-Der $p$} & \multicolumn{2}{|c|}{ Anti- Blot } \\
\hline & MÃE & RN & MÃE & RN & MÃE & RN & MÃE & RN & MÃE & RN & MÃE & RN & MÃE & $\mathbf{R N}$ & MÃE & $\mathbf{R N}$ & MÃE & RN & MÃE & RN & MÃE & $\mathrm{RN}$ \\
\hline 51 & 612 & 895 & 2708 & 2652 & 59,6 & 79,4 & 49,6 & 131 & 22 & 42,4 & 431,6 & 312,9 & 62 & 56,7 & 307,9 & 309,4 & 7,7 & 0 & 22,3 & 22,88 & 8,42 & 11,5 \\
\hline 64 & 986 & 1018 & 472,4 & 354,8 & 665 & 843,8 & 97 & 127 & 49 & 101 & 7,3 & 11 & 0 & 0 & 251,64 & 260,65 & 17,95 & 25,32 & 1,58 & 0,92 & 15,3 & 8,43 \\
\hline 68 & 620 & 984 & 535,4 & 626,2 & 565 & 1159 & 152 & 344,8 & 86,4 & 165,6 & 7,7 & 1,6 & 0 & 17,7 & 185,24 & 306,2 & 16,8 & 34,52 & 0,12 & 1,08 & 7,71 & 5,41 \\
\hline 103 & 646 & & 520 & 700 & 360 & 440 & 105,5 & 144,7 & 34,4 & 23,2 & 118 & 55,2 & 0 & 0 & 156 & 73,6 & 5,14 & 6,22 & 5,92 & 5,04 & 8,26 & 3,82 \\
\hline 105 & 577 & & & & 2369 & 2332 & 372,9 & 419,9 & 61,6 & 102,6 & 122 & 60,9 & 0 & 0 & 602,17 & 521,76 & 7,84 & 10,59 & 2,82 & 2,06 & 6,52 & 5,57 \\
\hline 111 & 913 & 989 & 3585 & 3296 & 2505 & 1646 & 126 & 196 & 32,8 & 60,2 & 750,1 & 686,8 & 587,7 & 839,5 & 509,6 & 434,39 & 9,27 & 10,62 & 25,46 & 25,14 & 6,98 & 7,78 \\
\hline 112 & 974 & 1074 & 1640 & 1280 & 4240 & 4240 & 307,6 & 368,15 & 126,8 & 138,4 & 6783 & 452,4 & 160,9 & 71,9 & 239,8 & 175,1 & 32,1 & 15,5 & 7,46 & 6,26 & 29,66 & 10,36 \\
\hline 117 & 694 & & & & 12948 & 15288 & 154,6 & 300,6 & 22 & 47,2 & 78,5 & 64,5 & 142,24 & 79,6 & 1006,5 & 1226,8 & 9,17 & 8,46 & 1,2 & 0,15 & 2,97 & 3,81 \\
\hline 120 & 554 & 725 & 190 & 190 & 360 & 600 & 34 & 72 & 38,4 & 95,7 & 26,9 & 27,6 & 0 & 0 & 195,65 & 191,35 & 9,92 & 12,56 & 0,82 & 0,74 & 2,88 & 3,69 \\
\hline 124 & 900 & 1173 & 210 & 230 & 7257 & 6736 & & & 43,4 & 105,2 & 32,8 & 27,3 & 230,2 & 186,4 & 148,08 & 109,88 & 80,3 & 90,12 & 0,32 & 0,46 & 8,67 & 3,3 \\
\hline 9 & 860 & 1030 & 78 & 67 & & & 15,6 & 41,7 & & & 0,8 & 0,6 & & & 38,3 & 10,03 & & & 0,6 & 0,5 & & \\
\hline 21 & 746 & 896 & 487 & 414 & & & 33,8 & 50,6 & 328,1 & 549,8 & 195,6 & 78,2 & 990,6 & 721,6 & 204,85 & & 21,75 & & 6 & 6,5 & 16,32 & 11,3 \\
\hline 24 & 982 & 1170 & 692 & 435 & & & 172,8 & 414,1 & 30,44 & 92,68 & 2,8 & 2,3 & 1724 & 1608 & 251,84 & 319 & 19,18 & 23,46 & 0,8 & 0,4 & 34,03 & 32,3 \\
\hline 32 & 923 & 1070 & 1451 & 1204 & & & 196,2 & 447,9 & 161,6 & 193,7 & 155 & 132,7 & 4488, & 3675 , & & 2330,7 & & 18,85 & 0,9 & 0,7 & 12 & 5,5 \\
\hline 44 & 754 & 1190 & 224 & 226 & & & 0 & 46,8 & & & 91,1 & 94,1 & & & 253,59 & 214,94 & & & 4,7 & 5,4 & & \\
\hline 47 & 797 & 1070 & 150 & 150 & & & 13 & 57,1 & & & 41 & 97,3 & & & & 77,56 & & & 3,6 & 4,5 & & \\
\hline 49 & 684 & 1020 & 234 & 331 & & & 72 & 128,9 & 79,52 & 181,1 & 1,1 & 1,2 & 0 & 0 & & & & & 5,4 & 1,7 & 22,4 & 13,7 \\
\hline 54 & 736 & 1270 & 645 & 733 & & & 50,2 & 118,7 & 18,56 & & 305 & 200,4 & 61,2 & & & & & & 11,1 & 12,8 & 7,99 & \\
\hline 55 & 489 & 920 & 752 & 973 & & & 49,3 & 66,1 & 124,3 & 205,1 & 25,4 & 61,7 & 131,2 & 59,9 & & 160,26 & & 16,7 & 42,3 & 37,3 & 37,54 & 22,5 \\
\hline 58 & 384 & 1450 & 1090 & 1193 & & & & & & & & & & & & 425,24 & & & & & & \\
\hline
\end{tabular}


(continuação)

\begin{tabular}{|c|c|c|c|c|c|c|c|c|c|c|c|c|c|c|c|c|c|c|c|c|c|c|}
\hline \multirow{3}{*}{ Iden tificação c } & \multirow{2}{*}{\multicolumn{2}{|c|}{$\begin{array}{l}\text { IgG sérica total } \\
\qquad(\mathrm{mg} / \mathrm{dL})\end{array}$}} & \multicolumn{4}{|c|}{$\begin{array}{l}\text { IgG sérica especifica } \\
(\mathrm{UA} / \mathrm{mL})\end{array}$} & \multicolumn{4}{|c|}{$\begin{array}{l}\text { IgG1 específica } \\
(\mathrm{UA} / \mathrm{mL})\end{array}$} & \multicolumn{4}{|c|}{$\begin{array}{l}\text { IgG2 específica } \\
(U A / \mathrm{mL})\end{array}$} & \multicolumn{4}{|c|}{$\begin{array}{l}\text { IgG3 específica } \\
(U A / \mathrm{mL})\end{array}$} & \multicolumn{4}{|c|}{$\begin{array}{l}\text { IgG } 4 \text { es pecífica } \\
(U A / \mathrm{mL})\end{array}$} \\
\hline & & & Anti- & erp & \multicolumn{2}{|c|}{ Anti- Blot } & \multicolumn{2}{|c|}{ Anti-Der $p$} & \multicolumn{2}{|c|}{ Anti- Blo $t$} & \multicolumn{2}{|c|}{ Anti-Derp } & \multicolumn{2}{|c|}{ Anti- Blo $t$} & \multicolumn{2}{|c|}{ Anti-Der $p$} & \multicolumn{2}{|c|}{ Anti- Blot } & \multicolumn{2}{|c|}{ Anti-Der $p$} & \multicolumn{2}{|c|}{ Anti- Blo $t$} \\
\hline & MÃE & $\mathbf{R N}$ & MÃE & $\mathbf{R N}$ & MÃE & $\mathrm{RN}$ & MÃE & RN & MÃE & RN & MÃE & RN & MÃE & RN & MÃE & RN & MÃE & RN & MÃE & RN & MÃE & RN \\
\hline 60 & 1140 & 1390 & 111 & 84 & & & 36,8 & 38,2 & 104,5 & 181,6 & 0,8 & 1,3 & 30,3 & 31,2 & & 55,64 & & 14,82 & 1,1 & 0,8 & 22,97 & 12,7 \\
\hline 63 & 1150 & 1050 & 1698 & 1776 & & & 190,9 & 127 & 19,32 & 160 & 16,5 & 1392,8 & 937,9 & 141,1 & & 105,94 & & 13,03 & 0,6 & 7,9 & 7,49 & 21,5 \\
\hline 84 & 912 & 1100 & 525 & 508 & & & 154,4 & 279,2 & 23,12 & 63,16 & 1,8 & 3,2 & 0 & 24,8 & & 1346,93 & & 21,56 & 0 & 0 & 5,53 & 5,1 \\
\hline 90 & 846 & 1060 & 1397 & 1094 & & & 68,8 & $?$ & 213,5 & 454,5 & 50,3 & 23,3 & 1107,1 & 806,8 & & 485,45 & & 30,4 & 0,5 & 0,6 & 22,2 & 27,9 \\
\hline 91 & 797 & 876 & 69 & 91 & & & 56,5 & 52,5 & 68,26 & 139,4 & 0,8 & 0,8 & 232,3 & 282,5 & & 6,78 & & 20,42 & 12,5 & 18,7 & 22,1 & 22,9 \\
\hline 103 & 831 & 855 & 1849 & 1535 & & & 230,3 & 296,8 & 278,1 & 566,3 & 89,9 & 62,3 & 287,9 & 372,4 & & 1837,96 & & 22,94 & 7,2 & 4,5 & 21,34 & 24,4 \\
\hline 116 & 1040 & 665 & 2078 & 1893 & & & 7058,2 & 902,9 & 85,8 & & 49 & 19,1 & 0 & 0 & & & & & 25,8 & 25,6 & 15,03 & \\
\hline 124 & 991 & 911 & 262 & 167 & & & 13,8 & 55,7 & 59,8 & 94,84 & 189,8 & 33 & 452,5 & 479,9 & & 261,8 & & 10,28 & 0,9 & 0,5 & 21,47 & 21,3 \\
\hline 125 & 896 & 1110 & 390 & 347 & & & 55,1 & 80,1 & 364,2 & 781,4 & 11 & 16,8 & 981,2 & 576,4 & & 192,65 & & 42,98 & 2,1 & 2,5 & 27,49 & 39,5 \\
\hline 132 & 822 & 1330 & 779 & 1205 & & 2457 & 97,7 & 1366, & 221,8 & 310,0 & 37,6 & 13,8 & 0 & 0 & & & & & 4,9 & 0,9 & 11,46 & 12,2 \\
\hline 133 & 710 & 939 & 575 & 419 & & 141 & 24 & 67,8 & 170,5 & 21,2 & 234,6 & 163,4 & 43 & 111.7 & & 367,3 & & & 19,6 & 13,7 & 39,35 & 30,1 \\
\hline 138 & 837 & 1010 & 756 & 548 & & 2019 & 106,2 & 235,7 & 0 & 7,66 & 175,6 & 141,6 & 443,2 & 450,5 & & 790,4 & 43,6 & 33,15 & 39,3 & 30,1 & 77,66 & 66 \\
\hline 139 & 778 & 986 & 199 & 203 & & 1189 & 85,7 & 146,1 & 48,3 & 91,4 & 3,5 & 4,7 & 190 & 322,8 & & 412,9 & & 18,7 & 0,4 & 0,7 & 13,32 & 16,39 \\
\hline 142 & 808 & 917 & 1561 & 1071 & & 6400 & 15,4 & 42,3 & 20,3 & 64,8 & 579 & 620 & 426,8 & 591,2 & & 66,1 & & 0 & 6,77 & 3,1 & 16,89 & 12,6 \\
\hline 144 & 1050 & 984 & 217 & 137 & & 1050 & 15,3 & 17,6 & 25,48 & 35,8 & 15 & 9,3 & 0 & 0 & 98,1 & 26,01 & 13,5 & 0 & 27,6 & 1,5 & 23,08 & 13,43 \\
\hline 146 & 813 & 974 & 519 & 654 & & & 138,9 & 199,2 & & & 33 & 58,7 & & & & 146,1 & & & 15,5 & 48,5 & & \\
\hline 5 & 1070 & & 530 & 428 & 630 & 703 & 205,36 & 317,04 & 139,5 & 231 & 5,4 & 2,2 & 19 & 0 & 176,95 & 147,9 & 23,63 & 21,78 & 102,4 & 92,7 & 12,13 & 14,44 \\
\hline 36 & 970 & 806 & 650 & 434 & 1380 & 1280 & 170,8 & 264,48 & 83,6 & 163,3 & 18,4 & 9,6 & 0 & 0 & 393,92 & 372,12 & 20,35 & 18,65 & 4,44 & 1,44 & 11,17 & 4,18 \\
\hline 54 & 1119 & 1295 & 2040 & 1410 & 1520 & 1480 & 137,6 & 156,56 & 92,2 & 169,3 & 233,9 & 156,6 & 0 & 0 & 361,04 & 359,8 & 14,44 & 39,44 & 0,58 & 0,88 & 2,82 & 4,39 \\
\hline 56 & 931 & 1436 & 1180 & 1510 & 6933 & 6265 & 453,48 & 473,12 & 35,2 & 77,9 & 15,3 & 8,7 & 682,6 & 870,7 & $\mathbf{x}$ & $x$ & $x$ & $x$ & 0,5 & 0,79 & 1,92 & 12,13 \\
\hline
\end{tabular}


(conclusão)

\begin{tabular}{|c|c|c|c|c|c|c|c|c|c|c|c|c|c|c|c|c|c|c|c|c|c|c|}
\hline \multirow{3}{*}{ Iden tificação c } & & & \multicolumn{4}{|c|}{$\begin{array}{l}\text { IgG sérica especiffica } \\
\text { (UA/mL) }\end{array}$} & \multicolumn{4}{|c|}{$\begin{array}{l}\text { IgG1 específica } \\
\text { (UA/mL) }\end{array}$} & \multicolumn{4}{|c|}{$\begin{array}{l}\text { IgG2 es pecífica } \\
\text { (UA/mL) }\end{array}$} & \multicolumn{4}{|c|}{$\begin{array}{l}\text { IgG3 e specífica } \\
\text { (UA/mL) }\end{array}$} & \multicolumn{4}{|c|}{$\begin{array}{l}\text { IgG } 4 \text { es pecífica } \\
\text { (UA/mL) }\end{array}$} \\
\hline & \multicolumn{2}{|c|}{$\begin{array}{l}\text { IgG sérica total } \\
(\mathrm{mg} / \mathrm{dL})\end{array}$} & Anti- & Derp & \multicolumn{2}{|c|}{ Anti- Blot } & \multicolumn{2}{|c|}{ Anti-Der $p$} & \multicolumn{2}{|c|}{ Anti-Blot $t$} & \multicolumn{2}{|c|}{ Anti-Der $p$} & \multicolumn{2}{|c|}{ Anti Blot } & \multicolumn{2}{|c|}{ Anti-Der $p$} & \multicolumn{2}{|c|}{ Anti-Blot } & \multicolumn{2}{|c|}{ Anti-Der $p$} & \multicolumn{2}{|c|}{ Anti-Blot } \\
\hline & MÃE & $\mathrm{RN}$ & MÃE & RN & MÃE & RN & MÃE & $\mathrm{RN}$ & MÃE & $\mathrm{RN}$ & MÃE & RN & MÃE & $\mathrm{RN}$ & MÃE & RN & MÃE & $\mathrm{RN}$ & MÃE & RN & MÃE & RN \\
\hline 90 & 690 & 1115 & 680 & 760 & 2023 & 2270 & 40,56 & 104,88 & 108,3 & 280,9 & 486,6 & 696,9 & 155,6 & 224 & $\mathbf{x}$ & $\mathbf{x}$ & $x$ & $\mathrm{x}$ & 2,75 & 2,18 & 5,42 & 14,19 \\
\hline 101 & 1329 & 1183 & 326,8 & 245,2 & 1098 & 687 & 57,72 & 86,16 & 30,9 & 62,4 & 5 & 3,9 & 48,8 & 90,4 & 339,2 & 202,59 & 32,2 & 101 & 22,18 & 21,7 & 567,6 & 379,3 \\
\hline 109 & 804 & 442 & 1659,2 & 1077,6 & 4574 & 4334 & 102,36 & 134,48 & 135,6 & 155,6 & 219 & 102,5 & 1776,4 & 1785,2 & $x$ & $x$ & $\mathrm{x}$ & $x$ & 17,68 & 7 & 13,53 & 14,92 \\
\hline 110 & 656 & 809 & 322,6 & 294 & 3044 & 3145 & 43,28 & 102,96 & 46,8 & 118,4 & 25,2 & 27,8 & 363,2 & 514 & 135,77 & 92,66 & 22,31 & 39,28 & 0,52 & 0,47 & 21,65 & 14,43 \\
\hline 118 & 1202 & 1243 & 669,8 & 592,6 & 708 & 835 & 76,64 & 86,4 & 908 & 194,6 & 11,9 & 7,9 & 32,8 & 44,8 & 135,64 & 134,57 & 9,27 & 13,89 & 15,14 & 16,74 & 41,59 & 37,35 \\
\hline 130 & 715 & 757 & 1253,6 & 1033,6 & 1030,5 & 1268,5 & 231,2 & 408,8 & 23,6 & 64,8 & 259,7 & 277,3 & 212,7 & 248,2 & $x$ & $x$ & 29,1 & 25,9 & 16,15 & 11 & 8,65 & 10,6 \\
\hline 131 & 988 & 992 & 976,8 & 888,4 & 2566 & 2733 & 216 & 313 & 84,6 & 81,2 & 57,4 & 37,4 & 0 & 0 & 462,72 & 359,6 & 18,36 & 24,8 & 0,8 & 0,7 & 1,44 & 1,96 \\
\hline 41 & 672 & 730 & 258,6 & 189,6 & 533 & 601 & 103,4 & 124,8 & 39,2 & 87 & 7,8 & 3,4 & 23,3 & 41,9 & 194,07 & 156,08 & 11,22 & 17,46 & ind & ind & 1,13 & 4,48 \\
\hline 107 & 728 & 897 & 524 & 854,4 & 325,4 & 331,2 & 83,8 & 114 & ind & 16 & 8,6 & 12,7 & 206,6 & 68 & 406,7 & 496,99 & 3,65 & 4,08 & 20,48 & 19,28 & 11,21 & 12,8 \\
\hline 79 & 652 & 956 & 520 & 760 & 20102 & 31954 & 246,41 & 446,8 & 239,5 & 221,2 & 10,3 & 11,2 & 24,4 & 43 & 198,02 & 237,46 & 27,22 & 24,22 & 22,4 & 23,86 & 10,4 & 14,48 \\
\hline 91 & 692 & 1132 & 836,8 & 1424,4 & 3424 & 5090 & 160,63 & 335,68 & 221,2 & 662,8 & 175 & 314,7 & 6322,6 & 7514,4 & 547,07 & 495, 92 & 259,96 & 108,9 & 28,54 & 28,46 & 58,07 & 71,33 \\
\hline
\end{tabular}


Anexo C

Níveis de IgA total, IgA e lgG específica, TGF-beta e alérgenos Derp 1 e Blo $t 5$ no colostro. 


\begin{tabular}{|c|c|c|c|c|c|c|c|c|}
\hline \multirow{2}{*}{ Identificação da mãe } & \multicolumn{2}{|c|}{$\begin{array}{l}\text { IgG específica no colostro } \\
\text { (UA/mL) }\end{array}$} & \multicolumn{2}{|c|}{$\begin{array}{l}\text { IgA específica no colostro } \\
\text { (UA/mL) }\end{array}$} & \multirow{2}{*}{$\begin{array}{l}\text { IgA total no colostro } \\
(\mathrm{mg} / \mathrm{mL})\end{array}$} & \multirow{2}{*}{$\begin{array}{c}\text { TGF-be ta no colostro } \\
(\mathrm{pg} / \mathrm{mL})\end{array}$} & \multicolumn{2}{|c|}{$\begin{array}{l}\text { Alérgeno no colostro } \\
(\mathrm{pg} / \mathrm{mL})\end{array}$} \\
\hline & Anti-Der $p$ & Anti-Blo $t$ & Anti-Der $p$ & Anti-Blot & & & $\operatorname{Der} p 1$ & Blo $t 5$ \\
\hline 16 & 145,2 & 425,3 & 388 & 95,5 & 12,5 & 174,5 & 78,02 & 0 \\
\hline 17 & & & & & & & & \\
\hline 19 & 1276,8 & & & & 62,5 & 366,1 & 20 & \\
\hline 24 & 10807 & 38,66 & 1077,9 & 210,5 & 65,8 & 1536,2 & 425,62 & 0 \\
\hline 38 & 17,8 & 4,06 & 314,9 & 475,1 & 11,4 & 288,64 & 53,6 & \\
\hline 47 & & & & & & & & 2000 \\
\hline 70 & 608,8 & 166,5 & 1054,3 & 221 & 20,3 & 2182,8 & 641,65 & 0 \\
\hline 74 & & & & & & $844,0 ? ? ?$ & & \\
\hline 78 & 98,4 & 278,6 & 633 & 395,2 & 27,1 & 1293,3 & 123,9 & 139,42 \\
\hline 80 & & & & & & & & 0 \\
\hline 94 & 1146,8 & 66,66 & 1153 & 321,6 & 66,8 & & 457,07 & 0 \\
\hline 116 & 50,8 & & 335 & & 5,6 & 194,29 & 26 & \\
\hline 122 & 7290 & & 1067,9 & & 68,3 & 2777,4 & 576 & 7271,035 \\
\hline 126 & 1877,5 & & 696,5 & & 129,3 & 2375,5 & 1126 & \\
\hline 4 & 6947 & & 8240 & & 127,6 & 1024,5 & 33,7 & 0 \\
\hline 13 & 3297 & & 4573 & & 105,2 & 1298,9 & 601,29 & 0 \\
\hline 7 & 247 & & 305 & & 28,2 & 1232,85 & & 0 \\
\hline 17 & 247,8 & & 484 & & 35,5 & 1360,47 & & 3327 \\
\hline 23 & 4349,9 & & 621 & & 19,9 & 7214,31 & & 0 \\
\hline 34 & 25,9 & & 163 & & 6 & 262,27 & 167,16 & 2062,46 \\
\hline
\end{tabular}


IgG específica no colostro (UA/mL)
IgA específica no colostro (UA/mL)
IgA total no colostro
Alérgen o no colostro

$(\mathrm{pg} / \mathrm{mL})$

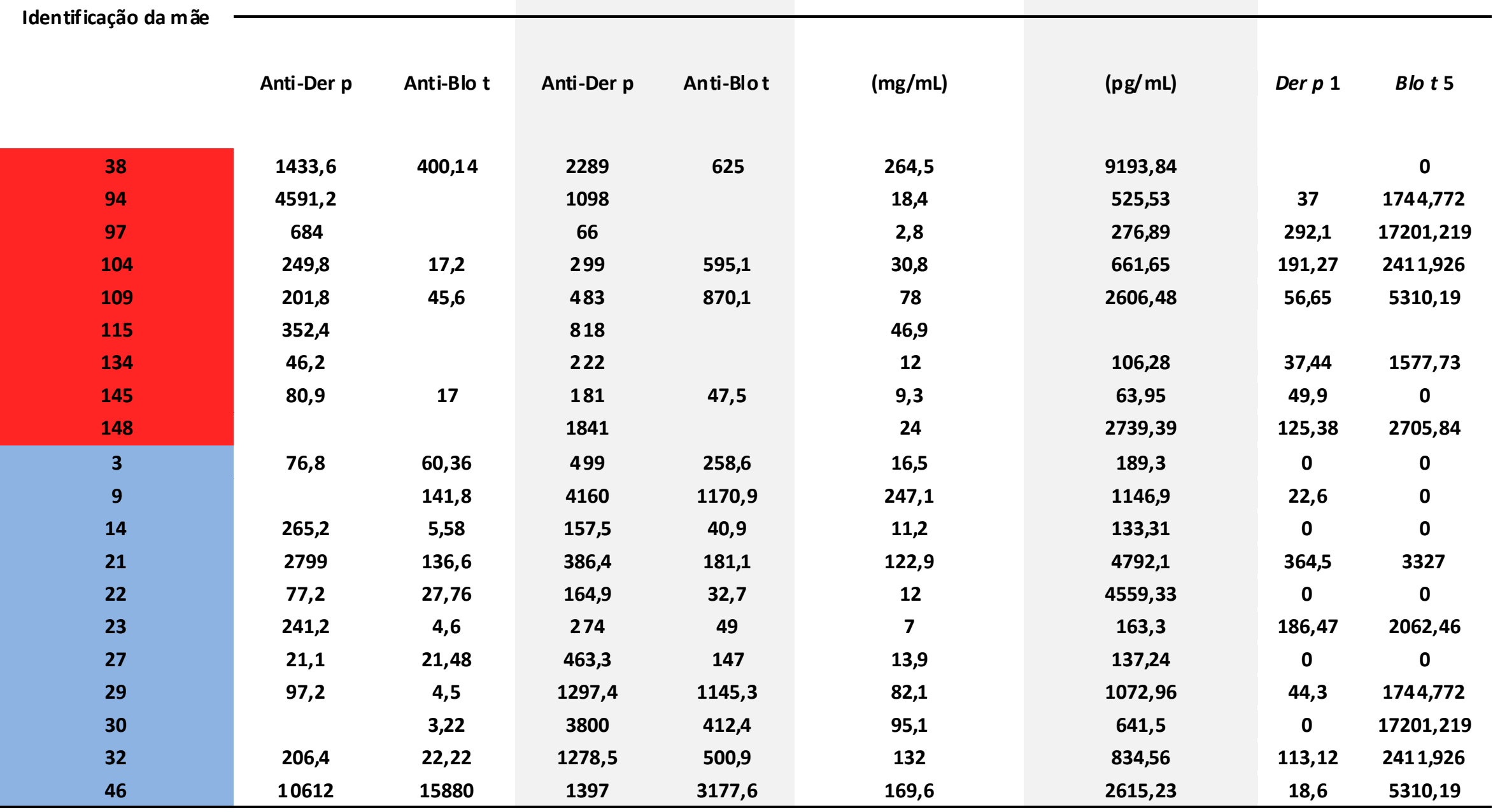


IgG específica no colostro (UA/mL)
IgA específica no colostro (UA/mL)
IgA total no colostro
Alérgen o no colostro

$(\mathrm{pg} / \mathrm{mL})$

Identificação da mãe

$\begin{array}{llll} & \\ \text { Anti-Der } p & \text { Anti-Blo } t & \text { Anti-Der } p \quad \text { Anti-Blot } & (\mathrm{mg} / \mathrm{mL})\end{array}$

TGF-be ta no colostro

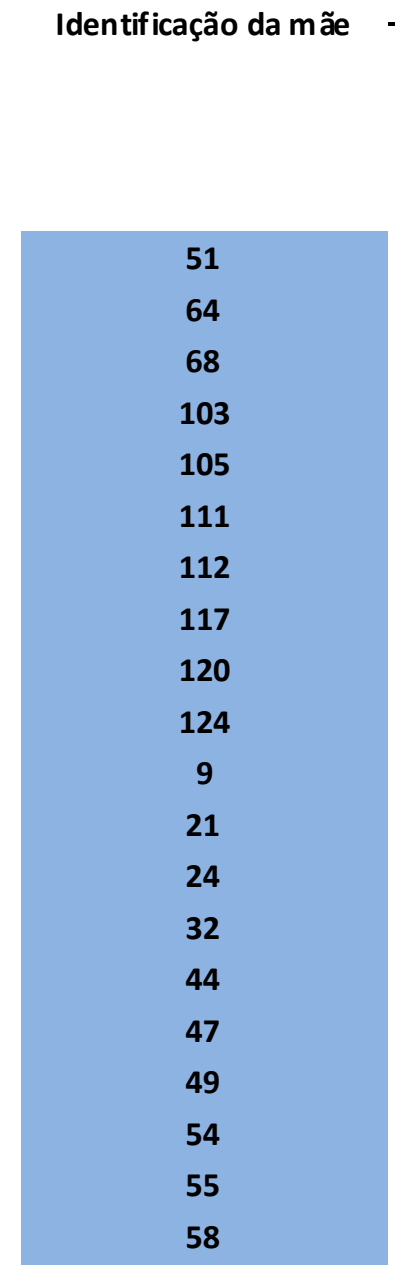

$\begin{array}{cc} & \\ 87,8 & 0 \\ 59,2 & 79,6 \\ 287,7 & 23,8 \\ 110 & 11,34 \\ & 8088,7 \\ 4318 & 42,8 \\ 152 & 16,1 \\ & 23 \\ 3,7 & 1,08 \\ 38 & 16,6 \\ 18 & \\ 172,6 & 110,68 \\ 1446,2 & 640,7 \\ 156,6 & 59,2 \\ 3,5 & \\ 14,9 & \\ 32,2 & 26,8 \\ 68,2 & 33,14 \\ 4548,8 & 18807,8 \\ 227,4 & \\ & \end{array}$

$\begin{array}{cc}130 & 64,8 \\ 1263,3 & 1064,9 \\ 2653 & 466 \\ 1110 & 111,7 \\ 411,1 & 146,8 \\ 677,5 & 292,3 \\ 475 & 197,6 \\ 538,5 & 231,8 \\ 208,9 & 61,7 \\ 620,1 & 262,2 \\ 173 & \\ 600 & 284,1 \\ 3161 & 1146 \\ 179 & 27 \\ 258 & \\ 46 & \\ 370 & 270,1 \\ 209 & 98,9 \\ 2761 & 685 \\ 119 & \\ & \end{array}$

\begin{tabular}{|c|c|c|}
\hline$(\mathrm{pg} / \mathrm{mL})$ & $\operatorname{Der} p 1$ & Blot 5 \\
\hline 146,118 & 239,17 & \\
\hline 3989,93 & 213,49 & 1577,73 \\
\hline 785 & 0 & 0 \\
\hline 1773,41 & 42,17 & 2705,84 \\
\hline 2791,64 & 62 & \\
\hline 721,75 & 0 & 1208 \\
\hline 189,88 & 0 & 0 \\
\hline 429,52 & 0 & 1164 \\
\hline 100,65 & 0 & 0 \\
\hline 331,11 & 0 & 0 \\
\hline 504,77 & 37,66 & 1425,6 \\
\hline 156,7 & 99,81 & 1316,182 \\
\hline 1977,09 & 119,23 & 0 \\
\hline \multirow[t]{2}{*}{600,61} & 77,78 & 0 \\
\hline & & 0 \\
\hline 177,46 & 46,2 & 0 \\
\hline 1051,52 & 0 & 0 \\
\hline 2598,52 & 0 & 0 \\
\hline 5348,48 & 53,54 & 144,88 \\
\hline 672,5 & 0 & 3125,92 \\
\hline
\end{tabular}


IgG específica no colostro (UA/mL)
IgA específica no colostro (UA/mL)
IgA total no colostro
Alérgen o no colostro

$(\mathrm{pg} / \mathrm{mL})$

Identificação da mãe

$\begin{array}{llll}\text { Anti-Der } p \quad \text { Anti-Blo } t \quad \text { Anti-Der } p \quad \text { Anti-Blot } & (\mathrm{mg} / \mathrm{mL})\end{array}$

TGF-be ta no colostro$$
\text { ( }
$$

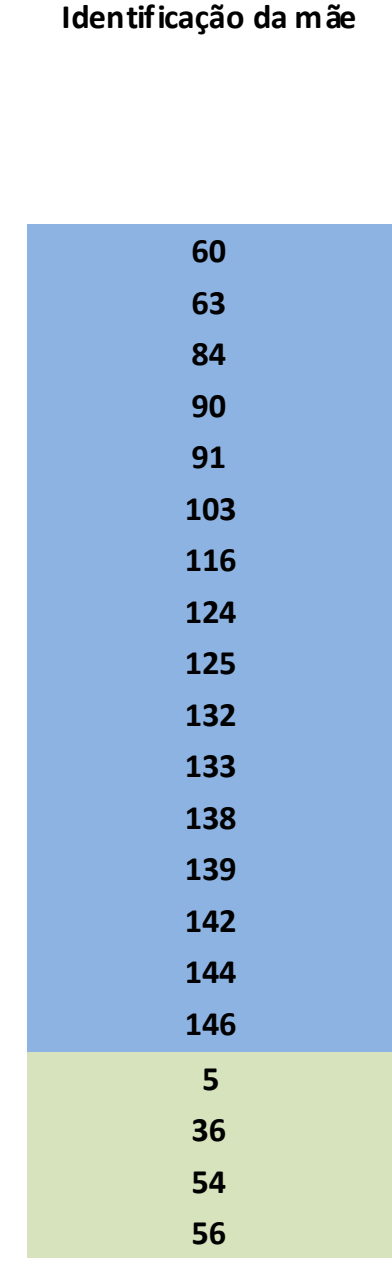

Anti-Der $p$

\begin{tabular}{|c|c|c|c|}
\hline 26,9 & 13,56 & 254 & 144,5 \\
\hline 2357,5 & 8766,1 & 2969 & 714,8 \\
\hline 23,2 & 0 & & 101 \\
\hline 2785,8 & 12672 & 1992 & 377,7 \\
\hline 4,8 & 1,7 & 429 & 699,5 \\
\hline 476,2 & 30,9 & 21,5 & 54,97 \\
\hline 867,4 & 5,26 & 224 & 95,2 \\
\hline 34,8 & 3,24 & 248 & 403,3 \\
\hline \multirow[t]{2}{*}{44,2} & 179,5 & 309 & 276,8 \\
\hline & & $\mathbf{x}$ & \\
\hline 121,2 & & 843 & 402,9 \\
\hline \multirow[t]{2}{*}{195,8} & & 1310 & 527,5 \\
\hline & & $x$ & \\
\hline 853,4 & & 446 & 518,9 \\
\hline \multirow[t]{2}{*}{8,1} & & 38 & 28,4 \\
\hline & & 1105 & \\
\hline 94,8 & 16,4 & 211,5 & 97,8 \\
\hline 15,6 & 2,36 & 271,9 & 197,6 \\
\hline 383,6 & 31,66 & 2893,3 & 495,9 \\
\hline 178 & 71 & 360,25 & 121,7 \\
\hline
\end{tabular}


IgG específica no colostro (UA/mL)
IgA específica no colostro (UA/mL)
IgA total no colostro
TGF-be ta no colostro
Alérgen o no colostro

$(\mathrm{pg} / \mathrm{mL})$

Identificação da mãe

Anti-Der $p \quad$ Anti-Blo $t$

90
101
109
110
118
130
131
41
107
79
91

416,8
16,6
55,6

338,
ind
49,5
250,8
51,6

\section{1,28}

$$
12,78
$$$$
4,8
$$

338,8

ind.

49,5

250,8

51,6
14228

121,6
5,54

0
179,5

Anti-Der $p$

Anti-Blot

78,7

766

207,2

242,1

153,6

330,5

226

227,5

484,2

211,5
151,9

53,4

78,4

207,4

108,4

(mg/mL)

4,4

20,7
12,6

13,5
19,2
7,6
29,5
11,7

$\operatorname{Der} p 1$

$(\mathrm{pg} / \mathrm{mL})$

508,1

256,07

1372,8

343,57

141,62

220,44

221,1

79,7
Blo t 5

$22,7 \quad 9033,84$

8

7,5

40

$0 \quad 0$

$11,3 \quad 0$

50,9

$68,55 \quad 0$ 


\section{Anexo D}

Níveis de lgM específica e alérgenos no cordão umbilical. 
Anexo D - Níveis de lgM específica e alérgenos no cordão umbilical

\begin{tabular}{|c|c|c|c|c|}
\hline \multirow{2}{*}{ Identificação da mãe } & \multicolumn{2}{|c|}{$\begin{array}{l}\text { IgM específica no cordão umbilical } \\
\text { (UA/mL) }\end{array}$} & \multicolumn{2}{|c|}{$\begin{array}{l}\text { Alérgeno no cordão umbilical } \\
\qquad(\mathrm{pg} / \mathrm{mL})\end{array}$} \\
\hline & Anti-Der $p$ & Anti-Blot & Der $\mathrm{p} 1$ & Blot 5 \\
\hline 16 & 3,28 & 2,6 & 37,78 & 0 \\
\hline 17 & 1,04 & 2,36 & 33,09 & 1036,15 \\
\hline 19 & 2,38 & & 0 & \\
\hline 24 & 2,39 & 1,77 & 13,5 & 0 \\
\hline 38 & 0,14 & 0,97 & 33,99 & 0 \\
\hline 47 & 3,22 & 2,32 & 258,86 & 0 \\
\hline 70 & 4,93 & 3,88 & 0 & 0 \\
\hline 74 & 3,36 & & 0 & \\
\hline 78 & 7,84 & 6,05 & 0 & 0 \\
\hline 80 & 5,32 & 3,68 & 0 & 0 \\
\hline 94 & 2,67 & 1,39 & 60,4 & 389,18 \\
\hline 116 & 1,89 & & 0 & \\
\hline 122 & 3 & & 34,29 & \\
\hline 126 & 4,12 & & 0 & \\
\hline 4 & 3,25 & & 0 & \\
\hline 13 & 2,83 & & 0 & \\
\hline 7 & 5,8 & & & \\
\hline 17 & 2,2 & & 0 & \\
\hline 23 & 4,9 & & & \\
\hline 34 & 3,32 & & & \\
\hline 38 & 4,14 & 2,85 & & \\
\hline 94 & 2,97 & & & \\
\hline 97 & 2,8 & & & \\
\hline 104 & $\mathbf{x}$ & & & \\
\hline 109 & 2,92 & 2,13 & 32,74 & 0 \\
\hline 115 & 1,36 & & 28,85 & \\
\hline 134 & 2,32 & & & \\
\hline 145 & 5,12 & 3,3 & & \\
\hline 148 & 3,82 & & & \\
\hline
\end{tabular}


(continuação)

\begin{tabular}{|c|c|c|c|c|}
\hline \multirow{2}{*}{ Identificação da mãe } & \multicolumn{2}{|c|}{$\begin{array}{l}\text { IgM específica no cordão umbilical } \\
\text { (UA/mL) }\end{array}$} & \multicolumn{2}{|c|}{$\begin{array}{l}\text { Alérgeno no cordão umbilical } \\
\qquad(\mathrm{pg} / \mathrm{mL})\end{array}$} \\
\hline & Anti-Derp & Anti-Blo $t$ & Der $p 1$ & Blot 5 \\
\hline 3 & 1,65 & 3,63 & 0 & 0 \\
\hline 9 & 2,43 & 1,55 & 0 & 0 \\
\hline 14 & 2,3 & 1,95 & 0 & 0 \\
\hline 21 & 111,74 & 83,42 & 0 & \\
\hline 22 & 2,74 & 2,14 & 62,26 & 1280,54 \\
\hline 23 & 2,61 & 2,02 & 0 & 0 \\
\hline 27 & 3,15 & 3,64 & 0 & 0 \\
\hline 29 & 1,87 & 0,74 & 14,71 & 0 \\
\hline 30 & 2,03 & 1,93 & 0 & 0 \\
\hline 32 & 5,18 & 2,82 & 0 & 0 \\
\hline 46 & 4,02 & 3,11 & 0 & 0 \\
\hline 51 & 3,2 & 2,43 & 0 & 0 \\
\hline 64 & 3,92 & 2,81 & 178,35 & 1240,48 \\
\hline 68 & 6,89 & 5,48 & 0 & 0 \\
\hline 103 & 2,83 & 1,49 & 869,85 & 0 \\
\hline 105 & & & 0 & 0 \\
\hline 111 & 8,32 & 5,26 & 89 & 0 \\
\hline 112 & 2,36 & 0,78 & 0 & 0 \\
\hline 117 & 1,76 & 0,69 & 0 & 0 \\
\hline 120 & 4,28 & 1,53 & 0 & 0 \\
\hline 124 & 1,87 & 0,71 & 4,9 & 0 \\
\hline 9 & 2,04 & & 67,2 & \\
\hline 21 & 6,22 & 3,92 & & \\
\hline 24 & 3,65 & 1,41 & & \\
\hline 32 & 3,19 & 2,29 & 0 & 0 \\
\hline 44 & 2,68 & & & \\
\hline 47 & 2,32 & & & \\
\hline 49 & 1,84 & 3,75 & & \\
\hline 54 & $\mathbf{x}$ & $\mathbf{x}$ & & \\
\hline
\end{tabular}




\begin{tabular}{|c|c|c|c|c|}
\hline \multirow{2}{*}{ Identificação da mãe } & \multicolumn{2}{|c|}{$\begin{array}{l}\text { IgM específica no cordão umbilical } \\
\text { (UA/mL) }\end{array}$} & \multicolumn{2}{|c|}{$\begin{array}{l}\text { Alérgeno no cordão umbilical } \\
\qquad(\mathrm{pg} / \mathrm{mL})\end{array}$} \\
\hline & Anti-Derp & Anti-Blo $t$ & Der $p 1$ & Blot 5 \\
\hline 55 & 3,7 & 4,41 & & \\
\hline 58 & 13,01 & & 124,28 & \\
\hline 60 & 1,93 & 2,01 & & \\
\hline 63 & 1,79 & 3,29 & 0 & 0 \\
\hline 84 & 3,04 & 2,13 & & \\
\hline 90 & 4,15 & 3,76 & & \\
\hline 91 & 3,77 & 25,66 & & \\
\hline 103 & 5,52 & 3,61 & & \\
\hline 116 & & & & \\
\hline 124 & 1,22 & 3,08 & & \\
\hline 125 & 2,84 & 4,26 & & \\
\hline 132 & 4,77 & 1,85 & 0 & 0 \\
\hline 133 & 6,76 & 3,13 & 41,53 & 0 \\
\hline 138 & 0,11 & 2,82 & 61,97 & 0 \\
\hline 139 & 2,81 & 0,82 & 117,03 & 0 \\
\hline 142 & 34,7 & 1,13 & 115,19 & 0 \\
\hline 144 & 3,31 & 22,59 & 0 & 0 \\
\hline 146 & 1,09 & & 49,91 & \\
\hline 5 & 3,14 & 2,69 & 0 & 0 \\
\hline 36 & 2,02 & 1,67 & 0 & 0 \\
\hline 54 & 2,41 & 1,26 & 0 & 0 \\
\hline 56 & 4,7 & 2,54 & & \\
\hline 90 & 2,44 & 2,3 & & 0 \\
\hline 101 & 0,78 & 0,54 & 0 & 0 \\
\hline 109 & 3,3 & 1,16 & & 0 \\
\hline 110 & 5,64 & 4,72 & 0 & 0 \\
\hline 118 & 2,46 & 1,74 & 0 & 0 \\
\hline 130 & 2,75 & 1,21 & & 541,36 \\
\hline 131 & 2,95 & 2,7 & 0 & 0 \\
\hline
\end{tabular}




\begin{tabular}{|c|c|c|c|c|}
\hline \multirow{2}{*}{ Identificação da mãe } & \multicolumn{2}{|c|}{$\begin{array}{l}\text { IgM específica no cordão umbilical } \\
\text { (UA/mL) }\end{array}$} & \multicolumn{2}{|c|}{$\begin{array}{l}\text { Alérgeno no cordão umbilical } \\
\qquad(\mathrm{pg} / \mathrm{mL})\end{array}$} \\
\hline & Anti-Der $p$ & Anti-Blo $t$ & Der $p 1$ & Blo t 5 \\
\hline 41 & 2,44 & 1,32 & 0 & 748,55 \\
\hline 107 & 0,73 & 0,63 & 0 & 0 \\
\hline 79 & 5,71 & 4,02 & 0 & 0 \\
\hline 91 & 5,58 & 4,83 & 0 & 0 \\
\hline
\end{tabular}




\section{Anexo E}

Padrão de reatividade das imunoglobulinas $\lg G$ e $\lg A$ frente aos extratos totais de Der $p$ e Blo $t$ em amostras pareadas de colostro, soro materno e soro de cordão umbilical. 
Anexo E: Padrão de reatividade das imunoglobulinas $\lg G$ e $\lg A$ frente aos extratos totais de Der $p$ e Blo $t$ em amostras pareadas de colostro, soro materno e soro de cordão umbilical.

(a) Extrato de Dermatophagoides pteronyssinus
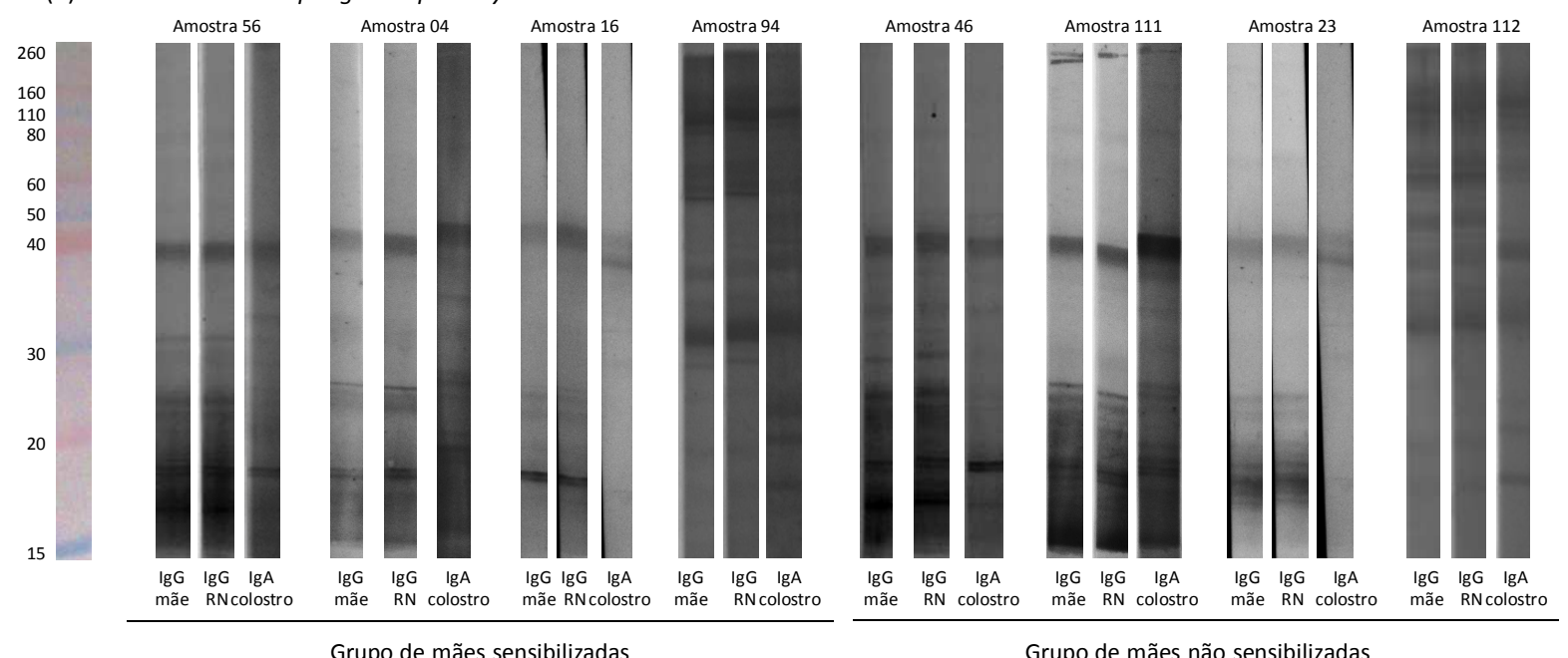

(b) Extrato de Blomia tropicalis
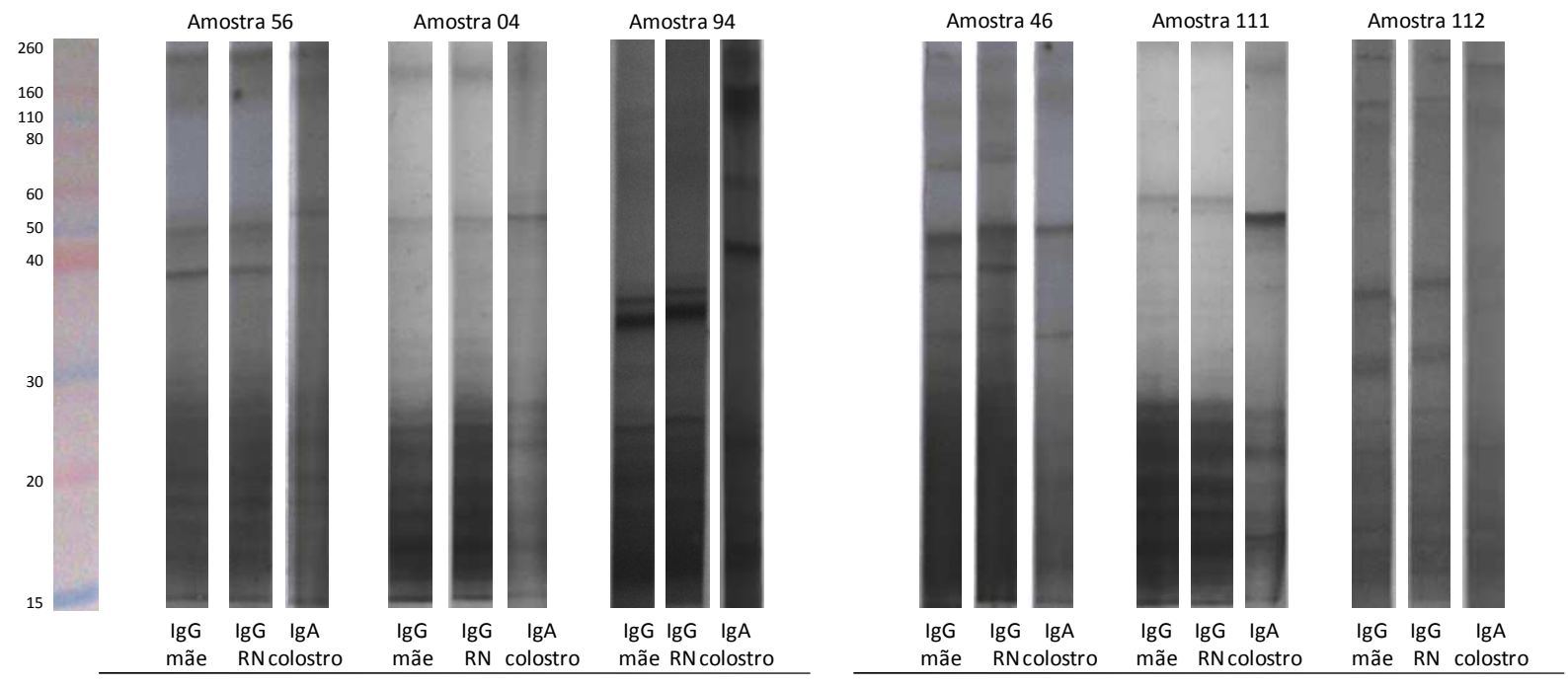

Grupo de mães sensibilizadas

Grupo de mães não sensibilizadas

Immunoblotting em gel $12 \%$ com extrato bruto de $\operatorname{Der} p(\mathrm{a})$ e Blo $t$ (b) juntamente com amostras pareadas de soro materno (mãe), de cordão umbilical $(R N)$ e sobrenadante de colostro (colostro). Revelação com conjugado anti-IgG humana (soro) ou anti-IgA humana (colostro). O peso molecular está expresso em kDa à esquerda da figura. 